UNIVERSIDADE DE SÃO PAULO

INTITUTO DE FÍSICA, INSTITUTO DE QUÍMICA, INSTITUTO DE BIOCIÊNCIAS E FACULDADE DE EDUCAÇÃO

JORGE LUIZ NICOLAU JUNIOR

Estrutura didática baseada em Fluxo: Relatividade Restrita para o Ensino Médio

v. 1

São Paulo

2014 


\section{JORGE LUIZ NICOLAU JUNIOR}

\section{Estrutura didática baseada em Fluxo: Relatividade Restrita para o Ensino Médio}

em dois volumes

v. 1

Dissertação de mestrado apresentada ao Instituto de Física, ao Instituto de Química, ao Instituto de Biociências e à Faculdade de Educação da Universidade de São Paulo para a obtenção do título de Mestre em Ensino de Ciências.

Área de Concentração: Ensino de Física

Orientador: Prof. Dr. Maurício Pietrocola Pinto de Oliveira.

São Paulo 


\section{FICHA CATALOGRÁFICA \\ Preparada pelo Serviço de Biblioteca e Informação do Instituto de Física da Universidade de São Paulo}

Nicolau Junior, Jorge Luiz

Estrutura didática baseada em fluxo: relatividade restrita para o ensino médio. São Paulo, 2014.

Dissertação (Mestrado) - Universidade de São Paulo. Faculdade de Educação, Instituto de Física, Instituto de Química e Instituto de Biociências.

Orientador: Prof. Dr. Maurício Pietrocola Pinto de Oliveira

Área de Concentração: Física

Unitermos: 1. Física - Estudo e ensino; 2. Ensino e aprendizagem; 3. Relatividade (Física); 4. Física moderna; 5.

Prática de ensino; 6 . Material didático.

USP/IF/SBI-053/2014 


\author{
Jorge Luiz Nicolau Junior
}

\title{
Estrutura didática baseada em Fluxo: Relatividade Restrita para o Ensino Médio
}

\begin{abstract}
Dissertação de mestrado apresentada ao Instituto de Física, ao Instituto de Química, ao Instituto de Biociências e à Faculdade de Educação da Universidade de São Paulo, para obtenção do título de Mestre em Ensino de Ciências.
\end{abstract}

Banca examinadora:

Prof. Dr. Maurício Pietrocola Pinto de Oliveira (FE-USP) (Presidente)

Profa. Dra. Thaís Cyrino de Mello Forato (UNIFESP)

Prof. Dr. Ives Solano Araújo (UFRGS)

São Paulo

2014 


\section{DEDICATÓRIA}

Sua energia esteve em todo momento e frente aos problemas, só fez soluções.

Dedico este trabalho à minha querida esposa Michele. 


\section{AGRADECIMENTOS}

Aos meus amados pais Jorge e Silvia acima de tudo. Sem eles nada disso teria acontecido.

À minha irmã Simone que esteve sempre me apoiando, muito obrigado por tudo.

Aos professores Maurício Pietrocola e Ivã Gurgel pelo intenso apoio e confiança em todos os momentos.

Aos professores Armando Tagiku e Leandro dos Reis pela grande parceria e amizade.

A todos que acreditaram em mim e em nossa pesquisa.

$\begin{array}{ll}\text { Alexandre Bagdonas } & \text { Jessie Best } \\ \text { André Noronha } & \text { Kerstin Gedigk } \\ \text { Prof. Beatriz Fagundes } & \text { Prof. Lúcia Sasseron } \\ \text { Fábio Beig } & \text { Pedro Neto } \\ \text { Prof. Gesche Pospiech } & \text { Silvia Schmitt } \\ \text { Graciella Watanabe } & \text { Tadeu Nunes } \\ \text { Hélio Vicentini } & \text { Ulrike Böhm } \\ \text { Itamar Fernandes } & \text { A toda equipe do NuPIC }\end{array}$

À Faculdade de Educação de Universidade de São Paulo e ao Instituto de Física da Universidade de São Paulo pelo apoio institucional.

À Fundação de Amparo à Pesquisa do Estado de São Paulo, pela concessão da bolsa de mestrado e pelo apoio financeiro para a realização desta pesquisa.

Aos amigos que sempre estiveram ao meu lado. 


\section{RESUMO}

NICOLAU, J. L. Estrutura didática baseada em Fluxo: Relatividade Restrita para

- Ensino Médio. 2014. 262 f. Dissertação (Mestrado) - Instituto de Física, Instituto de Química, Instituto de Biociências e Faculdade de Educação da Universidade de São Paulo, São Paulo, 2014.

O presente trabalho conceitualiza e aplica da noção de "fluxo" como a parte da intenção didática relacionada com a qualidade das transições entre atividades de uma sequência didática. O fluxo foi empregado como protoprincípio central no desenvolvimento de um curso sobre Relatividade Restrita para o Ensino Médio com base na metodologia Design-Based Research (DBR). A dinâmica de trabalho contou com a participação de pesquisadores e professores da Rede Pública do Estado de São Paulo. Reuniões de discussão, produção e aplicações da sequência didática foram organizadas conjuntamente pelo Núcleo de Pesquisas em Inovação Curricular (NuPIC) e pelo, então formado, Grupo de Atualização da Física Escolar (GrAFiE). Como resultado da pesquisa foi apresentada a comparação entre o fluxo pretendido e a fluência observada pelos alunos. Uma pesquisa auxiliar sobre a compreensão do conceito de evento também é construída e complementa os resultados obtidos. Com vistas na generalização proposta pelos pesquisadores nessa área, são apresentados o protoprincípio de fluxo como potencial motor para o desenvolvimento de sequências didáticas, o diagrama de fluxo como representação prática das intenções dos desenvolvedores e o instrumento de fluxo como método para a produção de dados. Esses elementos foram testados em um ciclo de pesquisas e são destinados ao emprego em outras sequências didáticas.

Palavras-chave: Física - Estudo e ensino. Ensino e aprendizagem. Relatividade (Física). Física Moderna. Prática de ensino. Material didático. 


\section{ABSTRACT}

\section{NICOLAU, J. L. Didactical structure based on Flow: Special Relativity for High}

School. 2014. 262 f. Dissertação (Mestrado) - Instituto de Física, Instituto de Química, Instituto de Biociências e Faculdade de Educação da Universidade de São Paulo, São Paulo, 2014.

The present work conceptualizes and applies the concept of "flow" as part of the didactic intention related to the quality of transitions between activities of a design experiment. The flow was used as the central protoprinciple in the developiment of a course on Special Relativity for high school based on a Design-Based Research (DBR) methodology. The work has involved the participation of researchers and public school teachers of the State of Sao Paulo, Brazil. Meetings, production and didactic interventions were collectively organized. The comparison between the desired flow and fluency observed by the students was analyzed as a result of the research. An auxiliary research on the understanding on the concept of event is also constructed and complements the research. Looking forward the generalization proposed by researchers in this area, the protoprinciple of the flow was presented as a potential idea for the development of didactic sequences. The flow's diagram was presented as a practical representation of the intentions of the developers and the flow instrument has shown as a method for producing data. These elements were tested in a cycle of research and are intended for use in other design experiments.

Keywords: Design-Based Research. special relativity. modern physics. teaching pratice. Teaching-Learning Sequence. 


\section{SUMÁRIO}

\section{VOLUME 1}

DEDICATÓRIA

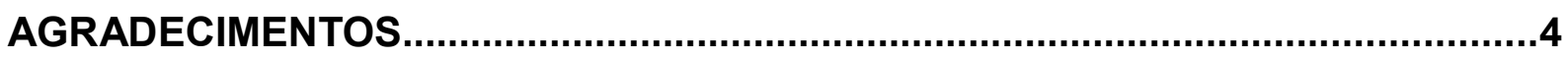

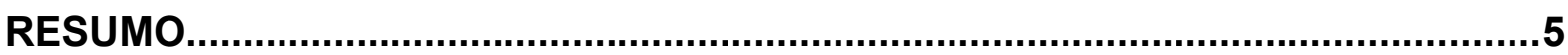

ABSTRACT

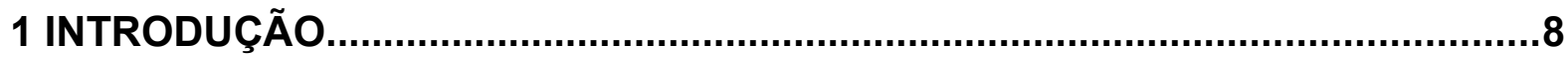

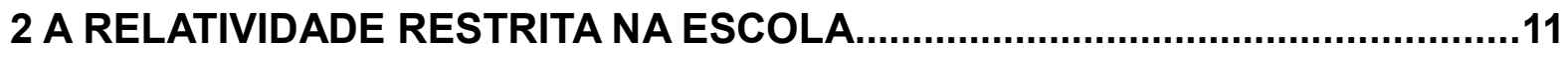

3 REFERENCIAIS TEÓRICO-METODOLÓGICOS................................................15

3.1 A TRANSPOSIÇÃO DIDÁTICA COMO PANO DE FUNDO ...............................15

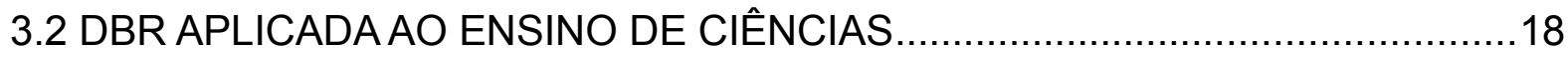

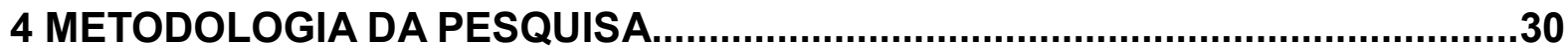

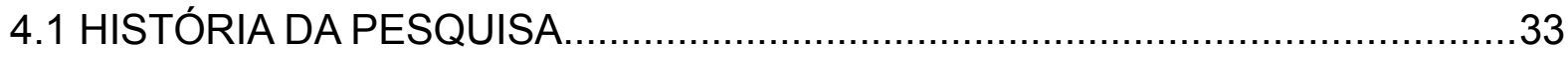

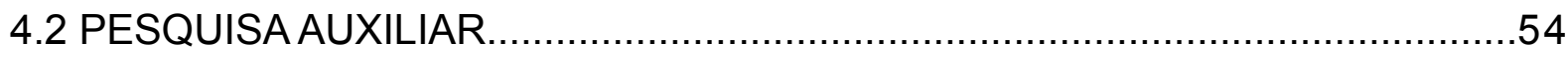

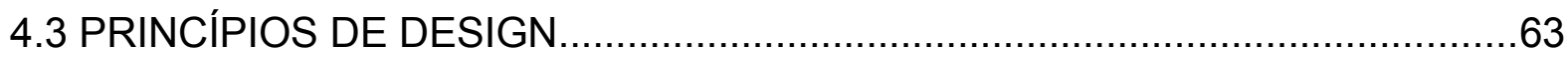

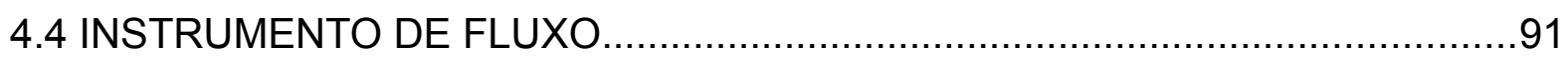

5 ANÁLISE

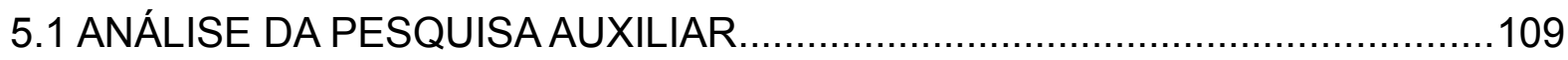

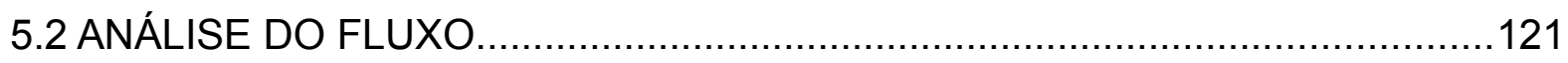

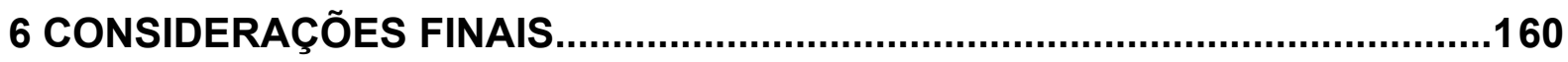

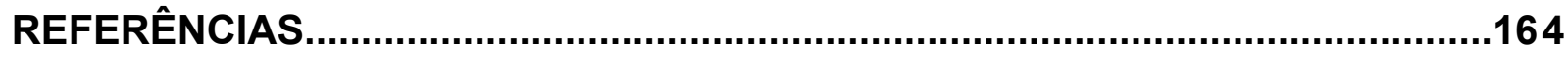

VOLUME 2

ANEXO 1 - SISTEMA EDUCACIONAL ALEMÃO...........................................170

ANEXO2 - MODELO DE FICHA DA PESQUISA AUXILIAR...............................176

ANEXO 3 - SEQUÊNCIA DIDÁTICA SOBRE RELATIVIDADE RESTRITA............180 


\section{INTRODUÇÃO}

Como professores muitas vezes nos perguntamos por que temas da Física que parecem interessar aos alunos acabam ficando fora dos currículos. Temas como "viagens no tempo" ou "teletransporte", que aparecem em filmes de ficção científica, deixam dúvidas sobre sua realidade e ficam em geral fora das aulas de Física da Educação Básica.

As dificuldades inerentes ao ensino e aprendizagem de temas da Física Moderna e Contemporânea (FMC) surgem em diversas instâncias. Como exemplo, é possível citar a média de idade dos alunos, inferior a 17 anos, o pouco domínio de conceitos físicos e técnicas matemáticas, a tradição curricular que tensiona os professores em direção aos temas já canonizados e a escassez de livros e materiais didáticos que incorporem com fluência temas e atividades inovadoras. Assim, ainda que interessantes, esses temas fogem da rotina escolar e trazem consigo obstáculos que dificultam sua incorporação na grade curricular.

Desde o início da década de 1990 se constrói a necessidade de modificar os currículos em termos de novos conteúdos de FMC com base em justificativas coerentes com a atualidade: a necessidade de formar cidadãos que compreendam e atuem no cotidiano, onde as diversas tecnologias modulam seus estilos de vida; a necessidade de compreender os contextos sociais onde se encontram; a necessidade de compreender as decisões de caráter científico e técnico que impactam seu ambiente próximo e o meio ambiente; a necessidade de emancipação intelectual para ampliar as visões de mundo e enraizá-las culturalmente visando adoção social e maior número de perspectivas criativas. Tais justificativas apresentaram um avanço considerável às propostas propedêuticas ou voltadas ao trabalho especializado que vigoravam anteriormente. Entretanto, ainda que currículos inovadores atuais estejam sob tais ideias, eles não são suficientes para indicar como implementar localmente conteúdos e atividades de FMC ou mesmo como apresentá-los aos professores desejosos em inovar suas aulas ainda que tenham tais currículos nas mãos. Os materiais disponíveis são em grande volume, especialmente na internet, mas estão desorganizados fazendo recair sobre o 
professor que está incorporando a nova prática uma carga de trabalho e insegurança muito grandes.

Deste modo, esta dissertação propõe um estudo intervencionista que visa desenvolver conhecimento sobre a aplicação de conteúdos relacionados à Relatividade Restrita (RR) em aulas do Ensino Médio. É utilizada metodologia de pesquisa com caráter empírico denominada Design-Based Research (DBR) a qual se destaca pela sistematização empregada tanto na produção de resultados de pesquisa, quanto na produção de materiais didáticos.

O estudo tem inspiração inicial no trabalho de Lijnse, P. (2004) onde foi discutida a necessidade das pesquisas em ensino focarem as situações reais de sala de aula em toda sua complexidade. A ideia de estrutura didática como uma construção que permite o melhor gerenciamento dos objetivos didáticos e de pesquisa motivou a forma de trabalho empregada neste estudo.

A sequência didática resultante desta dissertação é um resultado expressivo e pretende ser de utilidade prática também a professores que desejarem abordar conteúdos e metodologias semelhantes às tratadas neste estudo. Ela condensa conceitos, técnicas, ideias e experiência de um grupo de profissionais composto por professores e pesquisadores unidos pelo objetivo de desenvolver uma sequência curta de atividades sobre RR. Deste modo, espera-se que o material possua características favoráveis de adaptabilidade a novos contextos de aula e novos professores. O conteúdo conceitual central adotado é a relatividade do tempo na perspectiva einsteiniana e uma das condições de contorno adotadas foi a contextualização com base no Paradoxo dos Gêmeos.

Tal abordagem se diferencia das tradicionais ao tratar a transição da visão clássica para a visão relativística pautada quase exclusivamente na diferenciação temporal. A escolha em separar espaço e tempo pode aparentar um inconveniente para a construção da noção de espaço-tempo, uma vez que se trata de uma entidade indissociável no paradigma relativístico. Entretanto, a sequência se desenvolve sob a hipótese de que uma abordagem direta do conceito de espaçotempo seria muito longa e complexa não só para o aluno, mas também para os pesquisadores e professores que por ventura tivessem contato com a sequência após seu desenvolvimento.

Adota-se a recomendação de Collins, Joseph e Bielaczyc (2004) que convidam a comunidade científica do Ensino de Ciências a desenvolver padrões de 
pesquisa reconhecíveis aos demais pesquisadores por meio de estruturas, teorias e ideias que permitam ter continuidade evolutiva nas mãos de outros pesquisadores. Visando alcançar essa recomendação, foi disponibilizada a sequência didática e dados complementares no volume II desta dissertação.

Entretanto, é importante salientar que a sequência didática não é a finalidade desta pesquisa. A sequência constitui um meio para a construção de conhecimento sobre as relações que os alunos possuem com as atividades ao longo das aplicações. Assim, o desenvolvimento e organização de todo o trabalho não leva somente em consideração as relações professor-aluno-saber, típicas nas salas de aula, mas incorpora também, em mesmo peso e importância, elementos de pesquisa para verificar o andamento das aplicações e executar ajustes na estrutura didática original.

A dissertação em si se preocupa com aspectos variados relacionados ao desenvolvimento, aplicação e retorno das atividades desenvolvidas e tem como principal objetivo verificar se os alunos conseguem compreender os objetivos locais das atividades propostas e se a fluência das atividades já executadas permitem ao aluno antever os temas das atividades seguintes.

O trabalho também conta com uma pesquisa auxiliar resultante de um questionário com quatro questões e apresentado a todos os alunos antes do início das aplicações. Entretanto, apenas uma das questões deste questionário é analisada e utilizada na dissertação tendo em vista sua contribuição aos resultados da pesquisa como um todo. 


\section{A RELATIVIDADE RESTRITA NA ESCOLA}

Este estudo está relacionado ao contexto de produção e aplicação tornando importante a introdução das principais justificativas para a escolha da Relatividade Restrita (RR) como conteúdo físico associado à sequência didática mediadora da pesquisa. Para tanto, toma-se os debates sobre a inclusão da Física Moderna e Contemporânea (FMC) no Ensino Médio, os quais já ocorrem a mais de duas décadas. (OSTERMANN, F. \& MOREIRA, M. A., 2000; PEREIRA, A. P. \& OSTERMANN, F., 2009; TERRAZZAN, E. A. 1992; ZANETIC, J. 1989). As conclusões desses debates influenciaram as interpretações sobre quais seriam as competências, as habilidades e os conteúdos considerados fundamentais para preparar um jovem a viver e se desenvolver socialmente. Parte do consenso atingido passou a integrar os documentos oficiais sobre a educação básica (BRASIL, 1996; 1999; 2002). A Proposta Curricular do Estado de São Paulo pode ser vista como uma reação que visou adequar os currículos escolares com base na constatação de que os das escolas tradicionais eram inadequados aos dias hoje (PROPOSTA CURRICULAR DO ESTADO DE SÃO PAULO, 2008).

Como resultado de todo esse processo, aos poucos, os conteúdos modernos e contemporâneos chegaram às classes de aula solicitando aos professores práticas didáticas inovadoras que melhor se encaixassem a esse novo contexto que se configurou (KARAM, 2005; BROCKINGTON, 2005; SIQUEIRA, 2006).

São vários os conteúdos modernos e contemporâneos atualmente vistos como potencialmente ensináveis no Ensino Médio. Dentre eles, é possível citar temas como dualidade onda-partícula, espectroscopia e cores, física da nanotecnologia, radiações, partículas elementares. Cada qual envolvendo objetivos específicos de formação dos alunos e ao mesmo tempo exigindo a superação de dificuldades inerentes ao seu processo de ensino-aprendizagem. Em praticamente todos é possível encontrar uma dimensão interessante para o Ensino Médio possibilitando a exploração de diversos aspectos a serem utilizados com o intuito de formar um aluno consciente de seu lugar na sociedade, no universo natural e, 
possivelmente, em si mesmo. Nesse espírito, este trabalho associa conhecimentos e ferramentas para o ensino de RR, um ramo da Física Moderna muito conhecido e rico, mas ainda explorado de maneira irregular pelos professores de Física do Ensino Médio. Isto em parte, devido a obstáculos que se colocam ao longo caminho entre o desejo de ensinar e o saber ensinado.

A RR tem origem num conjunto de experiências, deduções e interpretações que no final do século XIX e início do século XX provocaram uma grande revolução no cenário científico. É possível ter uma leve impressão sobre a visão científica da época que antecede os trabalhos sobre relatividade feitos por Einstein em 1905 por meio das observações feitas por Lorentz:

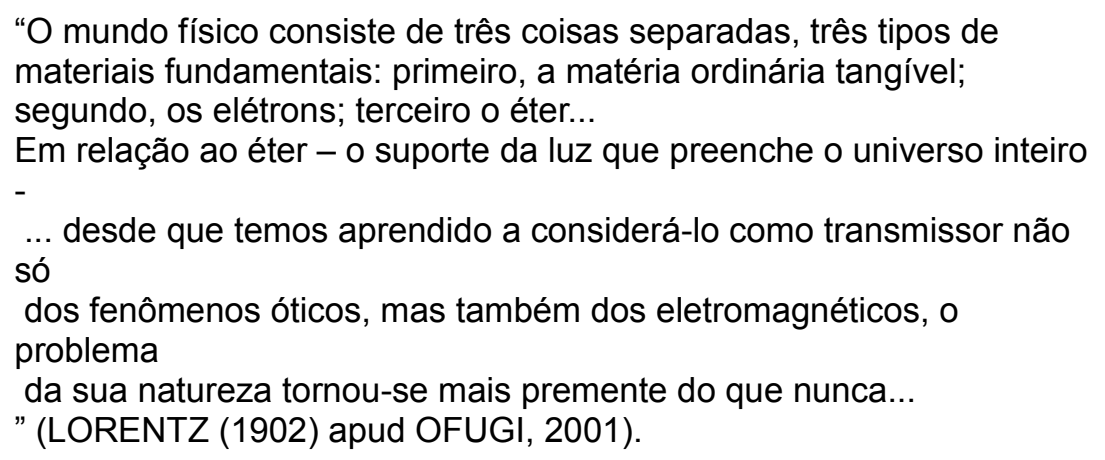

Os estudos feitos pela comunidade científica pré-relativística estavam preocupados com a natureza do éter e o fenômeno de propagação da luz. Nesse sentido, a manipulação da teoria eletromagnética de Maxwell proporcionava um valor constante para a velocidade da luz no vácuo, o que confirmava teoricamente, aos olhos da época, a existência de um referencial privilegiado e não detectável por experimentos mecânicos: o éter. O jovem Einstein de dezesseis anos, já tinha atenção voltada para esse problema e em nota autobiográfica apresenta o que seria o início de seu pensamento relativístico:

Se eu persigo um raio de luz com velocidade c (velocidade da luz no vácuo), eu deveria observar esse raio de luz como um campo eletromagnético oscilatório em repouso. Entretanto, parece que não há tal coisa, seja com base na experiência ou de acordo com as equações de Maxwell. Desde o início pareceu-me intuitivamente claro que, do ponto de vista desse observador, tudo teria de acontecer de 
acordo com as mesmas leis válidas para um observador que estivesse em repouso em relação à Terra. Pois como poderia o primeiro observador saber, ou seja, ser capaz de determinar que ele está em movimento uniforme rápido? (EINSTEIN, 1959, p. 53 apud ARUDA \& VILLANI, 1996)

Diversos experimentos precisos como o de Michelson e Morley em 1887 foram desenvolvidos utilizando a propagação da luz para detectar esse referencial absoluto ou alguma característica do éter parado em relação a ele. Estranhamente, para a época, a velocidade da luz parecia não se alterar com o movimento do observador relativo ao éter. FitzGerald, Lorentz e Poincaré desenvolveram as chamadas equações de Lorentz como uma saída compatível com as equações de Maxwell na tentativa de explicar tais resultados.

Fisicamente, as equações de Lorentz eram de difícil aceitação na época, pois indicavam que o comprimento de todos os corpos se modificavam na direção do movimento relativo do éter. Isso seria indetectável por que qualquer instrumento utilizado para detectar tal variação de tamanho seria também influenciado pelo movimento relativo. (BASSALO, 1997; ARRUDA \& VILLANI, 1996).

Tais equações foram encontradas por Einstein mais tarde, mas sob uma interpretação diferente. Em 1905 ele apresentou sua teoria da Relatividade Restrita: uma estrutura que matematicamente convergia para as transformações apresentadas por Lorentz, mas que proporia uma revolução nos conceitos mais profundos de espaço, tempo e energia presentes no paradigma newtoniano. A teoria da Relatividade Geral viria posteriormente expandindo a cinemática relativística para a dinâmica relativística, o que permitiria à comunidade científica compreender fenômenos até então obscuros assim como os desvios dos valores clássicos do periélio de Mercúrio e, posteriormente, a existência de buracos negros (KARAM, R. A. S.; CRUZ, S. M. S. C. DE S.; COIMBRA, D., 2007; PORTO, C. M. \& PORTO, M. B. D. S. M., 2008).

Após extensa articulação e aceitação do paradigma relativístico, a comunidade científica passou a compreender o universo físico de modo bem diferente do que se compreendia no século XIX. É esse universo estruturado por conceitos como espaço-tempo, massa-energia e por fenômenos como os de diferenciação temporal e contração espacial que se considera importante ao aluno. Entretanto, ainda que interessante, a seleção dos conteúdos de FMC a serem 
introduzidos no Ensino Médio não é tarefa trivial. A escolha deve ser feita com base em argumentos explícitos e aceitáveis principalmente pelos professores e desenvolvedores de currículos.

No caso da Relatividade, existem diversas motivações para o seu ensino no Ensino Médio e suas qualidades compõem um cenário muito frutífero para o desenvolvimento do conhecimento. Primeiramente, os conceitos básicos são sustentados por uma linguagem matemática relativamente simples e acessível à compreensão dos alunos (OGBORN, 2005; RUBY, 2009) facilitando a modelização de conceitos considerando a matemática como estruturante do conhecimento físico (PIETROCOLA, 2010). Por outro lado, a incompatibilidade da Física com a realidade cotidiana pode ser utilizada para ressaltar ao aluno a necessidade do conhecimento científico no avanço à sua compreensão da natureza, o que pode promover o reconhecimento de uma realidade diferenciada da que se apresenta limitada aos seus sentidos. Outra forma característica muito interessante inerente à RR é seu caráter epistemológico que também pode ser explorado para evidenciar a forma como o conhecimento se desenha frente a novas ideias e experiências e como as noções de mundo se modificam na Ciência.

Considerando o tema pertinente, como abordar esses conteúdos modernos e contemporâneos em classe? Quais atividades e posturas são efetivamente aplicáveis? Como ensiná-las? As experiências promovidas junto ao Núcleo de Pesquisas em Inovações Curriculares (NuPIC) indicam que tais questões são normalmente respondidas com intuição e experiência por parte dos professores, as quais certamente possuem importância inestimável, mas carregam consigo práticas aplicadas de forma a fortalecer algumas concepções alternativas ou tecer panos de fundo destoantes com o conhecimento científico formal. Assim, pesquisas sobre metodologias e práticas em contextos inovadores são consideradas importantes ferramentas para auxiliar os professores alinhados a estas demandas.

Essa pesquisa visa contribuir com uma fina fatia de conhecimento nesta área. A ideia é apresentar resultados que relacionam uma dimensão da intenção didática de professores envolvidos com a sequência à percepção dos alunos desta intenção. A pergunta de pesquisa tomada como central neste trabalho é: quão próximas estão a percepção dos alunos sobre a fluência das ideias apresentadas em classe e a fluência intencionada durante o desenvolvimento de uma sequência didática desenhada com base em pesquisas? 


\section{REFERENCIAIS TEÓRICO-METODOLÓGICOS}

Como o conteúdo da RR é inovador, ou seja, não possui uma versão didática tradicionalmente estabilizada pelos anos de aplicação e sedimentada por várias gerações de livros didáticos, é fundamental a existência de um guia teórico que permita o estudo e compreensão das transformações dos saberes científicos rumo à sala de aula. Para tanto, utiliza-se como pano de fundo a Transposição Didática (TD) (CHEVALLARD, 1991) a qual situa epistemologicamente os saberes didatizados nessa proposta.

Com relação às metodologias de pesquisa, toma-se como base a proposta de Design-Based Research (DBR) (DBR COLLECTIVE, 2003) em associação às Teaching Learning Sequences (TLS) (MÉHEUT E PSILLOS, 2004) para organizar o trabalho coletivo e guiar o olhar sobre a análise dos dados.

As noções de objetivo-obstáculo de Astolfi (1994), detalhes críticos de Viennot et. al.(2005) e os obstáculos epistemológicos e didático-pedagógicos aplicados ao ensino de ciências de Pietrocola (2008) serão os instrumentos utilizados para guiar e caracterizar a sequência didática desenvolvida.

\subsection{A TRANSPOSIÇÃO DIDÁTICA COMO PANO DE FUNDO}

A Transposição Didática (TD) é um instrumento que ajuda analisar as transformações que um saber originalmente desenvolvido no âmbito científico sofre até chegar à presença do aluno. Neste trabalho ela tem a função de ajudar a caracterizar o saber que estará em jogo na sequência de ensino-aprendizagem a uma distância razoável do saber científico de referência para que se possa observar as escolhas feitas durante sua produção, ou, nos termos de Chevallard (1991), durante a transposição da RR para o ambiente escolar. 


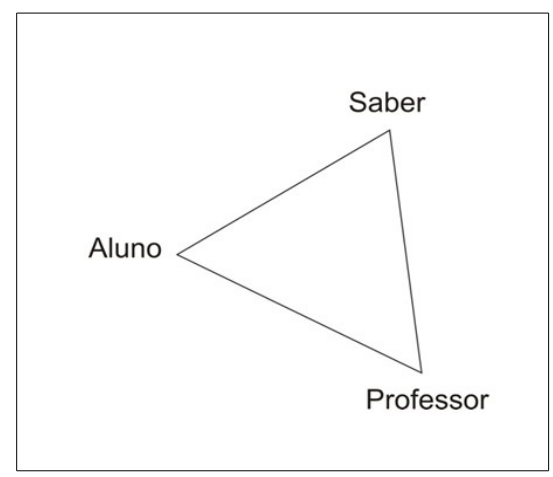

Figura 1 - Sistema didático proposto por Chevallard.

Yves Chevallard (1991), matemático francês desenvolvedor da teoria, se posiciona contra a exclusividade do que ele chama de famosa "relação professoraluno", a qual, segundo ele, teria obscurecido o estudo de outros eixos didáticos. Ele defende o "saber" como um terceiro importante elemento estruturando a didática por uma relação ternária entre professor, aluno e saber, Figura 1. A Transposição Didática versa mais diretamente sobre este terceiro elemento de modo a se constituir como uma ferramenta que auxilia na resposta à pergunta: Afinal que saber é esse, parte integrante do sistema didático, que está se transformando até às salas de aula?

\footnotetext{
"O conceito de transposição didática, por um lado se refere à passagem do saber sábio para saber ensinado, e por outro lado à eventual distância, obrigatória que os separa, testemunha a esse questionamento necessário, enquanto se converte em seu primeiro instrumento" (CHEVALLARD, 1991).
}

Ela ajuda compreender porque o saber científico, no nosso caso a RR, não sofre apenas uma simplificação até chegar à sala de aula. Na verdade ele se modifica profundamente sendo que a cada transformação, passa a se constituir um novo saber, pertencente a um novo nicho epistemológico.

$\mathrm{O}$ ambiente onde se encontram os agentes que modificam o saber durante a trajetória até sua apresentação ao aluno é denominado por noosfera. Ela se distingue do ambiente externo que contém os agentes que não influenciam a transformação do saber. A noosfera é dividida em três domínios principais: o saber 
sábio, o saber a ensinar e o saber ensinado, cada qual comportando saberes com características próprias definidas pelos seus respectivos agentes. Tais agentes são normalmente os cientistas, educadores, professores, políticos, autores de livros didáticos, pais de alunos, ou seja, todos os que com seus valores, objetivos ou preferências influenciam os caminhos que o saber percorre durante a transposição.

O saber sábio é o saber que surge das pesquisas científicas e circula através de revistas e jornais especializados. Tem a característica de estar vinculado aos métodos empregados pela comunidade científica. Constitui assim o saber de referência, validado, acessível para ser transposto para a sala de aula. O governo, quanto à destinação de verbas para financiamento de pesquisas, e todos os que influenciam na produção do saber sábio, também fazem parte da deste domínio, mas os que possuem maior influência são, sem dúvida, o cientista e a comunidade científica.

O saber a ensinar, é o saber normalmente encontrado didatizado nos livros didáticos, revistas de divulgação científica e documentários. Consideramos, por exemplo, que os conteúdos e instruções da sequência de ensino-aprendizado de Relatividade são saberes presentes nesse nicho epistemológico. Tais saberes são transpostos para o ambiente escolar sendo suscetível a interferências de muitos agentes, a saber: os professores, os especialistas de cada área do saber, os autores de livros didáticos e divulgação científica, a Secretaria da Educação e até a opinião pública. Tais agentes influenciam a transposição através de seus próprios valores e intenções, sendo que muitas vezes conflitos de ideias ocorrem gerando uma gama de transposições diversas. No caso desta pesquisa, a produção da sequência didática foi feita com base na metodologia DBR (apresentada mais adiante) promovendo melhor compreensão das escolhas didáticas feitas pelos integrantes desta parte da noosfera.

O saber ensinado, por sua vez, é o saber efetivamente produzido em sala de aula, transposto do domínio do saber a ensinar principalmente pelo professor no ato de lecionar. Esse saber é influenciado pelos diretores, orientadores educacionais, pela comunidade e é caracterizado especialmente quanto aos valores didáticos que o norteiam. Tais valores estão alinhados principalmente aos valores dos professores e alunos, uma vez que estes três agentes unidos por uma intenção didática produzem o sistema didático. A partir do saber ensinado esta pesquisa se concentra numa componente relacionada à fluência que os diferentes saberes 
promovidos pelas atividades possuem entre si, comparando-a com a fluência desenvolvida no domínio do saber a ensinar.

A TD é utilizada na pesquisa para situar os diversos saberes envolvidos. A sequência didática, por exemplo é considerada como um produto no saber a ensinar. Os saberes criados em classe durante as aplicações, por sua vez são produtos do saber ensinado. Os livros e artigos utilizados como fontes sobre a RR são os representantes do saber sábio nesta pesquisa.

\subsection{DBR APLICADAAO ENSINO DE CIÊNCIAS}

A Design-Based Research (DBR) é uma metodologia de pesquisa que pretende produzir respostas a partir de hipóteses ou prototeorias em contextos educacionais. A ideia principal é construir sequências didáticas usando processos iterativos cujos resultados de pesquisa permitam evoluir tanto o desenho das sequências didáticas, quanto as hipóteses ou prototeorias inicialmente propostas.

Em sua vertente norte-americana, considera-se aqui que a DBR se inicia com artigo de Brown, A. L. (1992). Nele o autor utiliza as ideias básicas de design presentes no trabalho de Collins, A. (1990) para o desenvolvimento de intervenções "que não somente funcionassem por padrões reconhecidos, mas fossem também baseados em descrições teóricas que delineassem porque elas funcionam para, então, torná-las confiáveis e reprodutíveis" (BROWN, A. L., 1992)1.

Collins, Joseph e Bielaczyc (2004) afirmam que "experimentos de design foram desenvolvidos como uma forma de realizar pesquisa formativa para testar e refinar designs educacionais baseados em princípios teóricos derivados de pesquisas anteriores." A dinâmica consiste em construir repetidas intervenções com questões de pesquisa bem definidas em seu núcleo para que sejam respondidas ou aprimoradas. Nesta perspectiva, espera-se que o processo cíclico evolua tanto as dimensões de hipóteses/prototeorias a serem testadas como as dimensões dos processos nos quais elas se desenrolam. Como o processo iterativo gira em torno de uma proposta de aplicação, um produto final com respaldo prático é normalmente

1 Tradução nossa: "In the classroom and in the laboratory, I attempt to engineer interventions that not only work by recognizable standards but are also based on theoretical descriptions tha delineate why they work, and thus render them realiable and repeatable." (BROWN, A. L., 1992, p.143) 
esperado, tal como um conjunto de práticas relevantes ou uma sequência didática.

De forma geral, a American Educational Research Association afirma que uma boa proposta de pesquisa baseada em DBR exibe cinco características que guiam o desenvolvimento do projeto em direção a dados e respostas de pesquisa mais confiáveis (DBR COLLECTIVE, 2003).

A primeira característica foi desenvolver a pesquisa associando os objetivos centrais da proposta às teorias, "prototeorias" e hipóteses, ou seja, trata-se de uma atitude de desenvolvimento das sequências de ensino-aprendizagem ativa e atenta ao controle dos parâmetros que serão observados.

Essa postura é bem interessante, pois a aplicação de uma sequência promove uma série de avanços positivos importantes, mas que muitas vezes não estão relacionados aos objetivos de pesquisa. Tais avanços são aceitáveis e até esperados no dia a dia escolar, já que os produtos das relações de ensinoaprendizagem em ação se estendem numa região de produção de conhecimentos maior do que normalmente objetivadas, especialmente se a sequência for desenvolvida e aplicada com responsabilidade.

Essa forma de pensar é corroborada por Astolfi (1994) quando trata sobre os obstáculos. Mesmo estando em um contexto de pesquisa diferente, ele afirma que:

\begin{abstract}
"Não se deve confundir o que governa uma sequência com o que se pode obter dela de uma forma secundária e derivada. Dependendo da autêntica dominância da sequência ser uma situação, um método, um saber ou um obstáculo, deverá se organizar de forma diferente o trabalho dos exemplos, assim com o tempo didático, a estrutura do diálogo com a classe ou a organização do trabalho em grupo, etc. Não é verdade que se possa manter de uma vez todos esse pontos de vista de maneira equivalente, e é possível vislumbrar qual é o que cada professor privilegia, incluso inconscientemente, já que ensinar é em primeiro lugar decidir, ou seja, eliminar outras opções virtualmente possíveis." (ASTOLFI,1992 apud ASTOLFI, 1994)
\end{abstract}

A abordagem de pesquisa DBR focaliza o olhar sobre parâmetros

2 Tradução nossa: "No se debe confundir lo que gobierna una secuencia con lo que se puede obtener de ella de una forma secundaria y derivada. Dependiendo de que la auténtica dominante de la secuencia sea una situación, un método, un saber o un obstáculo, se deberá organizar de forma diferente el trabajo de los ejemplos, así como el tempo didáctico, la estructura del diálogo con la clase o la organización del trabajo por grupos, etc. No es verdad que se puedan mantener a la vez todos estos puntos de vista de igual manera, y es posible entrever cuál es el que privilegia cada profesor, incluso inconscientemente, ya que enseñar es en primer lugar decidir, o sea, eliminar otras opciones virtualmente posibles"(ASTOLFI,1992 apud ASTOLFI, 1994, p. 207.)" 
específicos, controlados por objetivos delimitados, o que permitiria considerar confirmadas apenas as "prototeorias" claramente consideradas no desenho e intimamente relacionadas com os objetivos centrais da sequência de ensinoaprendizagem. Ou seja, a princípio, não se poderia defender hipóteses ou criar "prototeorias" que afirmassem que o aluno desenvolve conceitos matemáticos ou conhecimentos sobre a ontologia do espaço-tempo, por exemplo, se estes objetivos não estiverem centralmente colocados no desenho das atividades em análise.

A segunda característica apresentada diz respeito aos procedimentos gerais para a geração de resultados de pesquisa. Os conhecimentos são validados por processos cíclicos de desenho, aplicação, análise e redesenho permitindo que os resultados da modificação ou inclusão de parâmetros sejam analisados ciclo a ciclo, produzindo um conjunto de respostas restritas e confiáveis.

A terceira característica tem relação com a qualificação dos resultados frente à comunidade científica, eles devem ser compartilháveis e relevantes a professores e demais pesquisadores.

A quarta característica refere-se ao contexto de aplicação das sequências. Estas devem ser genuínas para que os resultados possam ser expressivos e compatíveis com a realidade de ensino que se deseja promover, no nosso caso, o Ensino Médio público. Mas, mais do que isso, a recomendação é que a pesquisa ultrapasse a observação das hipóteses e resultados abarcando também os processos interativos que ocorrem na produção e aplicação.

A quinta característica recomenda a utilização de métodos que documentem e garantam uma conexão entre os resultados e as aplicações das sequências didáticas.

Apesar de o termo design possuir origem norte-americana, sua forma de trabalho aparentemente tem raízes independentes também na Europa. Lijnse (1995) apresenta a Developmental Research como um caminho para o desenvolvimento empírico de estruturas didáticas de modo sistemático. Tal abordagem utiliza a construção de sequências didáticas como ferramentas de pesquisa e defende o uso de sequências curtas, testadas ciclicamente, em resposta à baixa eficiência das abordagens relacionadas à mudança conceitual feita por metodologias construtivistas gerais utilizadas na época. Lijnse (2004) utiliza esta ideia associada ao desenvolvimento das Teaching-Learning Sequences (TLS) cuja metodologia é definida em um artigo introdutório de Méheut \& Psillos (2004). Este apresenta as 
TLS como sequências didáticas que visam dois objetivos simultâneos: o primeiro é permitir e desenvolver pesquisa de intervenção que aborde aspectos de ensino e aprendizagem de conteúdos específicos, tais como o de ótica, calor ou eletricidade, por exemplo; o segundo, desenvolver um produto compreendido como uma ferramenta de ensino que engloba não só os conteúdos, mas também objetivos específicos, ambos potencializados pelos resultados desenvolvidos durante as intervenções.

Uma sugestão interessante para a construção e análise de sequências didáticas é apresentada por Buty, Tiberghien, \& Maréchal (2004). Eles sugerem que as hipóteses de pesquisa para a construção de sequências didáticas estejam distribuídas em três polos teóricos associados: epistemológico, psicológico e didático. Hipóteses importantes como as relacionadas ao conhecimento foram tratadas por eles no âmbito da TD. Já a modelização dos conceitos físicos foi associada à epistemologia da ciência como forma de justificar a necessidade de distinção entre teoria e realidade material na produção de sua sequência.

Com relação ao desenvolvimento da DBR junto à comunidade científica, Collins, A., Joseph, D., Bielaczyc, K. (2004) defendem a necessidade de abertura de uma linha de pesquisa de design em educação de ciências que promova investigações sobre quais variáveis seriam importantes e como os processos de ensino-aprendizagem dependem dessas variáveis. Ele afirma ser necessário que a comunidade científica se preocupe com a "criação de padrões que promovam pesquisas de design reconhecidas e acessíveis a outros pesquisadores." ${ }^{3}$ Van Den Akker (1999) corrobora com esta ideia quando afirma que

\footnotetext{
"Atividades de pesquisa realizadas durante o processo completo de desenvolvimento de uma intervenção específica (...) tem como objetivo a otimização da qualidade da intervenção assim como a especificação de princípios de design" (VAN DEN AKKER, 1999, p.6, apud, RAMOS, P. 2010).
}

Todo esse quadro metodológico tem a característica de se propor a produzir conhecimento didático sem necessariamente recorrer a teorias gerais de

3 "(...) the learning-sciences community needs to take reponsability for creating standards that make design experiments recognizable and accessible to other researchers, and for developing an infrastructure that can support summative evaluation (Collins, Joseph e Bielaczyc, 2004)." 
aprendizagem. O principal argumento utilizado é que o produto das teorias gerais educacionais tais como teorias socioconstrutivistas possuiriam aplicabilidade muito restrita e com resultados difíceis de serem conectados às expectativas do desenho didático original ao passo que processos aplicados experimentalmente desenvolveriam conhecimentos de maior praticidade e correspondência com as expectativas iniciais. Nesta direção, Lijnse (2004) faz crítica às sequências didáticas guiadas por teorias gerais afirmando que sob aplicação:

\footnotetext{
"tais teorias somente resultam, na melhor das hipóteses, em regras heurísticas. Tais regras simplesmente não podem garantir que o processo de ensino supostamente governado por elas terão a necessária qualidade didática." (LIJINSE, P., 2004; tradução nossa) ${ }^{4}$
}

Assim, a dificuldade na utilização de referenciais teóricos gerais diretamente aplicados na construção de materiais didáticos forma a base crítica para o uso da DBR.

Um termo polêmico é o de qualidade didática. Lijnse, P. (2004) defende que a ideia de qualidade didática é possível de ser sustentada se os resultados de aplicação forem produzidos a partir das intervenções feitas com base em uma estrutura didática. Isso porque, por um lado tais estruturas seriam operacionalizadoras dos pontos básicos que produzem os resultados e, por outro lado, seriam materiais práticos que representam o caminho mais conveniente para ensinar/aprender determinado assunto. A possibilidade de comparação entre o que é almejado e o que é efetivamente alcançado frente a esse tipo de estruturação de pesquisa é utilizada aqui, mas não se pretende apresentar nenhum índice de qualidade como proposto por Lijnse, P (2004).

A opção pelo uso da Design-Based Research (DBR) ocorreu com base na necessidade de uma transposição didática que incorporasse simultaneamente as perspectivas de ensino-aprendizagem presentes nas relações didáticas e as perspectivas de pesquisa necessárias para a construção e análise de dados.

A pesquisa propõe a construção de uma estrutura didática com base no protoprincípio denominado pelo pesquisador sob a nomenclatura de fluxo didático.

4 Tradução nossa. "(...) Such rules simply cannot guarantee that the teaching process that is supposed to be governed by them will have the necessary didactical quality." (Lijnse, P., 2004). 
Este possui a finalidade de guiar a produção e representar a intenção didática que os desenvolvedores tinham no momento em que conceberam os objetivos e materiais das atividades da sequência didática. O termo protoprincípio faz referência ao termo prototeoria apresentado por DBR Collective (2003), mas pretende ser algo mais simples. Espera-se que esse protoprincípio evolua em ciclos de pesquisas futuras para um princípio de design aplicável em outros contextos. Aqui ele é apresentado de modo a operacionalizar a produção de dados.

Deste modo, a pergunta de pesquisa pode ser reformulada segundo esse novo termo: quão próximos estão o fluxo didático idealizado e a efetiva percepção que os alunos desenvolveram desta fluência durante as atividades? ${ }^{5}$

\subsubsection{DBR na prática}

A DBR aplicada ao ensino de ciências se torna uma interessante ferramenta de pesquisa quando se trabalha com sequências didáticas. A organização e ações durante a pesquisa passam a depender dos objetivos almejados. O uso da DBR necessita que se tenha em mente os principais aspectos a serem seguidos. Além disso, é preciso criar uma forma de mantê-los firmes em sua importância durante o processo.

O requisito principal está relacionado à proposição de um experimento de design que desenvolva teorias passíveis de teste sobre algum aspecto objetivado. Essas teorias em geral possuem estruturas simples e não poderiam ser comparáveis a grandes teorias de aprendizagem. Quanto utilizadas, se apresentam como protoprincípios de design baseados em hipóteses iniciais lastreadas pela experimentação. Em consequência, este tipo de pesquisa se coloca fora de uma posição antropológica tradicional e aproxima-se mais da metodologia de pesquisa típica das ciências naturais onde se procura produzir o fenômeno para entendê-lo.

O protoprincípio apresentado nesta pesquisa é a ideia de fluxo didático, que será tratado em detalhes adiante. A hipótese associada a ele propõe a existência de um saber, relacionado à fluência entre as atividades da sequência, que permearia tanto a esfera do saber a ensinar quanto a esfera do saber ensinado. Ou seja, a intenção didática atenta à construção das transições entre as atividades promoveria

\footnotetext{
5 Se o leitor desejar, poderá comparar com a definição dos objetivos nas páginas 10 e 14 .
} 
elementos para o reconhecimento dos tópicos a serem tratados em sala de aula. Essa antecipação seria construída pelas relações entre o professor, aluno e material didático efetivamente presentes em classe, mas teria raízes no processo de produção da sequência didática.

A pesquisa DBR prevê que um contexto de pesquisa deve ser desenvolvido de modo a centralizar o protoprincípio no palco de ações. Nessa pesquisa, tal contexto é o de produção e aplicação de uma sequência de RR para alunos de Ensino Médio. O protoprincípio foi centralizado, por um lado, ao se colocar a ideia de fluxo como pivô do processo de produção da sequência, por outro, porque a construção de dados sobre o fluxo foi feita com base nas aplicações em sala.

Esse contexto, ainda que simples, só permite uma boa conexão entre as ações da produção e os resultados da aplicação por causa da presença do mesmo professor em ambos os processos. Participaram da pesquisa tanto professores que apenas receberam o material quanto professores que participaram do processo de desenvolvimento, entretanto apenas as aplicações dos segundos foram consideradas na análise dos resultados sobre o fluxo.

Esse ponto é sensível porque diferencia a pergunta sobre quanto da intenção didática voltada à conexão das atividades é percebida pelos alunos de uma outra pergunta sobre quanto uma sequência didática, escrita e consolidada, conseguiria refletir nos alunos a intenção de seus criadores, segundo a perspectiva de aplicação de professores que não participaram do desenvolvimento. Assim, os professores vinculados ao processo de desenvolvimento, estão em uma condição diferente dos professores que recebem a sequência didática pronta para utilizar em sua aula.

$\mathrm{Na}$ primeira condição, os professores produziram pessoalmente os elementos didáticos guiados pelo protoprincípio no saber a ensinar e os transpuseram para o saber ensinado. Os professores que participaram em ambos processos são considerados vetores e maiores conhecedores dos saberes relativos ao fluxo em todos os processos da sequência. Nesse sentido, o papel do professor vai além da garantia de que os saberes escolares permeiem o material e organização das atividades; ele é o agente que transforma a intenção didática guiada pelo protoprincípio de fluxo em ação didática efetiva na classe. Isso é importante, pois permitiu que o pesquisador construísse os dados referenciado pelo acompanhamento do trabalho daquele professor em ambas as pontas do processo. 
$\mathrm{Na}$ segunda condição, os professores possuíam recursos limitados ao material em si, às explanações advindas da perspectiva do pesquisador e por sua própria interpretação das atividades visto que eles não participaram do desenvolvimento. ${ }^{6}$

Até este ponto, toda a explicação sobre o uso prático da DBR pode levar a crer que não seria necessária a criação de uma sequência didática para efetuar a pesquisa. Aparentemente seria possível que a um professor possuidor de uma boa hipótese pudesse testá-la diretamente em seus próprios alunos e um questionário poderia ser usado como fonte de dados. Esse contexto de pesquisa é certamente válido, mas não se constitui em uma pesquisa de design. A grande diferença estaria no compromisso que a DBR possui com a generalização dos resultados, ou seja, a pretensão de torná-los respostas a contextos diversos além do desenvolvido.

Para compreender como isso foi feito, é preciso ter em mente que a sequência didática é uma construção complexa cujo significado em princípio difere para cada participante do projeto, assim como para qualquer um que entre em contato com ela. A aproximação de seus significados somente ocorre se o contexto de pesquisa for desenhado para isso. Esse é um dos grandes motivos para se construir a sequência coletivamente: condensar os diversos significados locais em uma estrutura reconhecível mais ou menos da mesma forma pela instância dos professores e pesquisadores. Sem isso não seria possível definir o fluxo de uma sequência produzida coletivamente.

Esse movimento de unificação das perspectivas foi feito pela instância de pesquisadores tomando-se a representação gráfica do fluxo como um guia ${ }^{7}$. Ainda que fosse perceptível que o fluxo também tivesse significados diferentes para os pesquisadores e professores durante as reuniões, a ideia de representá-lo graficamente por meio de um diagrama materializava e ajustava a região de significado na qual todos concordavam. Essa estratégia permitiu que a criação da sequência didática ocorresse sem idiossincrasias, mas, ao mesmo tempo, que mantivesse os saberes e experiências da prática docente de diversos professores em sua estrutura.

Outros dois princípios de design foram adotados e reconhecidos coletivamente para a produção da sequência: a existência de detalhes críticos e da

6 Os professores $A$ e $D$ com as turmas BR3A, BR3E e BR2E se enquadram no primeiro caso. Os professores E e F com as turmas DEGr e DELe se enquadram no segundo caso. Veja quadro 1.

7 Tanto o fluxo quanto o diagrama de fluxo, sua representação, serão tratados adiante. 
existência de obstáculos epistemológicos e didático-pedagógicos. Eles serão tratados com mais detalhes adiante.

A pesquisa DBR é composta por momentos distintos que organizam o desenvolvimento da pesquisa e permite sua evolução de forma cíclica. Cada ciclo é composto pelas etapas de desenho, de aplicação, de validação e de redesenho. A etapa de desenho comporta todas as ações de planejamento e construção da estrutura didática nas dimensões de pesquisa e de sala de aula. A etapa de aplicação é o momento dinâmico em que a estrutura produz os dados revelando situações inesperadas. Na prática é o período em que a sequência didática está sendo aplicada em classe. A etapa de validação é o momento de análise dos dados e comparação com as hipóteses de pesquisa. A etapa de redesenho é aquela em que o conhecimento operacional adquirido e o conhecimento produzido pelos dados (quando pertinente) são utilizados para melhorar o desenho de pesquisa original ou o protoprincípio presente no centro do planejamento.

Uma consequência desta perspectiva cíclica é a exigência de que o objeto sustentador do protoprincípio tenha alguma dimensão permanente, um núcleo duro que permita comparação de resultados após modificações no desenho de pesquisa. Para fins práticos, considera-se que se a sequência consegue condensar a experiência profissional de vários professores com base num protoprincípio de forma não idiossincrática, então ela possui um núcleo duro. Possui, desse modo, a possibilidade de ser testada e reconhecida frente a modificações controladas.

Como cada ciclo se revela uma tarefa trabalhosa ao pesquisador, na prática existe uma limitação no número de aulas que uma sequência didática pode ter para que a pesquisa seja viável. De acordo com a comunidade de pesquisadores da área, esse número estaria entre 7 e 11 aulas para uma pesquisa como essa.

Outro ponto essencial para a generalização dos resultados de uma pesquisa DBR é o conhecimento detalhado do "motor" de produção da sequência. Esse conhecimento permite o desenvolvimento e o controle nos ciclos de pesquisas seguintes. Talvez uma proposta em trabalhar com professores que não participaram do processo de desenvolvimento pudesse aprimorar os resultados na dimensão do reconhecimento do fluxo da sequência aumentando o poder de generalização das respostas. Ou ainda, uma pesquisa com professores voltada à validação do texto presente no material poderia generalizar mais os resultados sobre o fluxo em relação à produção local da sequência didática de RR. De fato, neste primeiro ciclo, 
a pesquisa procurou generalizar o conceito de fluxo presente na produção local entendendo o professor e o material didático como vetores que conectam as intenções didáticas à construção de conhecimento por parte do aluno.

Um aspecto de grande importância na DBR é o processo de validação para que seus resultados possam ser considerados pela comunidade científica. A validação é o processo responsável pela comparação dos dados produzidos com os objetivos de pesquisa. Esse processo é feito pela instância de pesquisadores e só é bem sucedido se a estratégia de construção de dados estiver intimamente ligada aos objetivos.

Nesta pesquisa, tal conexão foi feita com o instrumento de fluxo, instrumento de coleta de dados destinado à instância dos alunos. Pinçar informações sobre como é a fluência efetivamente percebida ao longo do curso, tendo em vista a generalização dos resultados, exige encarar o desafio em considerar as influências momentâneas típicas do conteúdo tratado em cada coleta de dados. Isso significa que certamente as respostas dos alunos são moduladas pelo momento didático em que se encontram. A forma adotada para tratar este aspecto foi a adequação do questionário de cada instrumento de fluxo a cada transição da sequência didática. Ou seja, coleta-se informações referentes à fluência percebida ( $2^{\mathrm{a}}$ etapa do instrumento $)^{8}$ ponderando-as com informações sobre o momento didático (1 ${ }^{a}$ etapa do instrumento) permitindo maior compreensão dos dados e generalização da análise.

Durante a pesquisa e desenvolvimento foram definidas três grandes instâncias de sujeitos ou participantes: alunos, professores e pesquisadores. Essa divisão não serve para determinar em detalhes o que se espera sobre o professor, aluno ou pesquisador. Ela apresenta de forma simplificada os papéis dos sujeitos dentro do processo de pesquisa e não em outros ambientes. O objetivo dessa definição foi organizar o trabalho de pesquisa em loco, pois o longo período e dinâmica de mudanças podem tornar confusas as funções e objetivos dos integrantes da equipe.

Utilizamos a definição apresentada por Coll, C. et al. (2000) como um primeiro guia para compreender o papel dos alunos na pesquisa:

8 O instrumento de fluxo será tratado em detalhes posteriormente. 


\begin{abstract}
"Uma pessoa adquire um conceito quando é capaz de dotar de significado um material ou uma informação que lhe é apresentada, ou seja, quando "compreende" esse material, em que compreender seria equivalente, mais ou menos, a traduzir algo para as suas próprias palavras." (COLL et al, 2000)
\end{abstract}

Essa definição associa informação e compreensão como uma transformação veiculada pelo aluno através da atribuição de significado. Para o professor, o aluno é visto como o principal sujeito, aquele que está no foco de sua atividade em classe quando promove condições para atribuições de significado. Entre os próprios alunos, o conteúdo possui maior relevância porque compreensão é a finalidade da sequência didática. Nesse sentido, não se deve confundir a finalidade da sequência com a finalidade da pesquisa. Para a instância de pesquisa, a atribuição de significado ao conteúdo feita pelo aluno é um acessório para compreender a percepção do fluxo, objetivo de pesquisa.

A instância dos professores pode ser compreendida inicialmente a partir do conjunto de saberes necessários para que um professor possa efetuar um bom trabalho docente (CARVALHO, A. M. P.; GIL-PÉREZ, 2006 e NICOLAU, J. L.; BROCKINGTON, G.; SASSERON, L. H., 2011): conhecer o conteúdo a ser ensinado sendo capaz de procurar mais informações caso julgue necessário; questionar o pensamento docente espontâneo; procurar conhecer teorias sobre aprendizagem; saber criticar, de modo fundamentado, o ensino tradicional; saber preparar atividades; saber dirigir a atividade junto aos alunos; saber avaliá-los; saber utilizar a pesquisa educacional e as inovações por ela trazidas como maneira de renovar e melhorar sempre sua prática docente. Todo esse espectro de saber e saber-fazer é um guia para definir o papel dos professores na pesquisa e praticamente todos eles demonstraram esses posicionamentos nos diferentes momentos do trabalho.

O comportamento efetivo do protoprincípio na sequência didática em aplicação só pode ser caracterizado a partir da implementação da atividade por um professor participante de todo o processo. O professor desenvolvedor é responsável por trazer informações e impressões sobre o contexto real de sala, pela implementação das ideias e técnicas acordadas no grupo e pelo compartilhamento das experiências adquiridas em classe, as quais são fundamentais para a modulação das abordagens didáticas feitas pelos demais integrantes.

O papel atribuído aos pesquisadores durante as tarefas de desenvolvimento 
pode ser compreendido pela descrição que Hernándes M. I., Pintó R. (in press) dão ao escopo de sua pesquisa:

"O papel dos pesquisadores consistiu de: (i) assegurar que os objetivos de aprendizado que cada tarefa possuísse fosse explicito; (ii) realizar a transposição didática dos conteúdos; e (iii) sugerir a abordagem didática a ser introduzida no material." Tradução nossa (HERNÁNDES, M. I. \& PINTÓ, R., in press) ${ }^{9}$.

Além dessas atribuições, os pesquisadores tiveram papel importante na negociação dos princípios de design frente a pluralidade de ideias dos professores. Foi também de sua responsabilidade a compilação e discussão das ideias acordadas durante as reuniões para a construção do diagrama de fluxo. Esse por sua vez precisou ser constantemente atualizado e frequentemente lembrado durante a construção das atividades.

Desta forma, os pesquisadores foram responsáveis pelas interferências que mantiveram os trabalhos com características típicas de pesquisa. O papel dos pesquisadores também foi: documentar as reuniões e aulas; manter a pesquisa documentável ao longo das transformações; organizar as discussões de modo a mantê-las dentro do escopo; promover transposições didáticas sobre o conteúdo de $\mathrm{RR}$; organizar e padronizar os materiais desenvolvidos.

9 The role of the RESEARCHERS consisted of: (i) guaranteeing that the specific learning targets that each task pursues are explicit; (ii) carrying out the didactical transposition of the contents; and (iii) suggesting the didactical approach to be introduced in the material (...).Hernándes M. I., Pintó R. (in press) 


\section{METODOLOGIA DA PESQUISA}

O Núcleo de Pesquisa em Inovações Curriculares (NuPIC) tem trabalhado a 12 anos em estudos relacionados ao desenvolvimento de sequências didáticas voltadas ao ensino de Física Moderna e Contemporânea (FMC). Ao longo deste período atuou em diversas dimensões do ensino incorporando teorias e aprimorando técnicas tanto de análise quanto de gerenciamento de projetos.

De certo modo, a adoção da Design-Based Research (DBR) como estruturadora do processo de desenvolvimento deste trabalho, assim como a Transposição Didática (TD) como guia para compreensão da epistemologia dos conhecimentos específicos, tem origem não só na tradição em produzir sequências didáticas voltadas a professores do Ensino Médio, mas também na busca sempre presente por ideias inovadoras com potencial de gerarem resultados significativos à comunidade científica.

Tendo em vista essa perspectiva, o Grupo de Atualização da Física Escolar (GrAFiE) foi criado por integrantes do NuPIC exclusivamente para o desenvolvimento de pesquisas utilizando sequências didáticas inovadoras sob coordenação dos professores Dr. Maurício Pietrocola da Faculdade de Educação da Universidade de São Paulo e Dr. Ivã Gurgel do Instituto de Física da Universidade de São Paulo. As atividades relativas a esta dissertação se iniciaram efetivamente em agosto de 2011 no Instituto de Física da Universidade de São Paulo (IFUSP) e terminaram em outubro de 2012. O grupo segue fazendo diversos outros trabalhos atualmente.

A sequência em si propõe os primeiros passos rumo à compreensão dos conceitos relativísticos tratando a diferenciação do tempo existente entre diferentes referenciais de modo a promover contato entre o mundo real e o mundo abstrato basicamente por meio de experiências de pensamento e discussões. A principal opção adotada para a transposição didática, e um dos grandes desafios que permearam todo o seu desenvolvimento, foi a busca pelo estudo da relatividade do tempo sem adentrar na relatividade do espaço, algo motivado pelo texto de Ferrer, A. M e Zanetic, J. (2002) e que não se encontra em livros sobre o assunto divergindo 
fortemente da estrutura deste conhecimento na esfera do saber sábio.

A sequência didática promove esse estudo tendo como tema o paradoxo dos gêmeos e se divide em 9 atividades (veja anexo 3, volume II) que duraram de uma a duas aulas conforme a relação didática existente entre professor, aluno e o conteúdo. $\mathrm{O}$ material foi produzido com base conceitual alinhada às propostas de Bechara, M. J., et al, (2007), Edwin F. T. \& Wheeler, J. A (1963) e Landau, L. \& Rumer, Y. (2004).

Numa visão geral, a sequência é divida em dois blocos. No primeiro bloco, as três atividades iniciais fazem um movimento que define e problematiza a parte física do mundo que será focada. Na primeira atividade uma situação absurda sobre gêmeos de idades diferentes é tratada para distinguir e ressaltar o tempo físico newtoniano frente a outras concepções de tempo que não seriam tratadas durante a sequência. Na segunda atividade é discutida uma situação real onde ocorre a diferenciação do tempo. A terceira atividade apresenta uma discussão de caráter histórico. A quarta e a quinta atividade vão em direção à abstração e generalização do conceito de diferenciação do tempo buscando um modelo para raciocinar situações relativísticas. Elas se afastam do mundo das percepções e exigem a construção de situações híbridas juntando elementos do cotidiano a situações não usuais de alta velocidade e mudança de referencial as quais exigem um grau de abstração muito maior. No segundo bloco, busca-se a especificação do uso da diferenciação temporal. O problema do paradoxo dos gêmeos é apresentado na atividade 6 . A noção de eventos e representação da linha de mundo é feita na atividade 7. As atividades 8 e 9 abordam o intervalo relativístico e a solução canônica do problema.

Um ponto central na apresentação da metodologia está relacionado com a forma como se encara a sequência didática dentro da pesquisa. Ficou claro ao longo do trabalho que a sequência composta pelo material físico destinado à sequência é normalmente confundido com a finalidade da pesquisa, ou seja, que à primeira vista a pesquisa se propõe a produzir uma sequência didática. Essa visualização é natural tendo em vista grande esforço empregado no desenvolvimento das atividades, dos materiais do professor e do aluno e pelas diversas aplicações que se sucederam.

Entretanto, é importante compreender que essa consideração não está totalmente correta. A sequência didática é melhor definida como o instrumento metodológico central para a produção de dados, ou seja, é importante mas não é o 
foco de análise deste trabalho. Ela é utilizada como um eixo que conecta as pretensões produzidas na esfera do saber a ensinar à esfera do saber ensinado. Desta forma, o leitor não deve estranhar que o desenvolvimento de toda a sequência didática seja apresentada como parte da metodologia.

Uma pesquisa auxiliar, muito específica, também foi feita para a verificação de um aspecto relacionado à forma como o aluno considera um acontecimento ou evento físico. A ideia foi verificar como o aluno se posiciona em relação à postura filosófica adotada na sequência didática que considera que um evento não depende de observadores para acontecer. A pesquisa se baseia num questionário prévio e será explicada em detalhes mais adiante.

A tomada de dados foi feita basicamente de duas formas. A forma exploratória se constitui dos dados utilizados de forma secundária na análise. Somam-se a eles as gravações de vídeo das atividades, as gravações em áudio das reuniões, anotações de campo, material dos alunos e os relatos dos professores sobre as aplicações. A forma direcionada está relacionada aos instrumentos de coleta construídos especificamente para processo de validação interno da DBR e busca pela resposta à pergunta de pesquisa. São eles, as fichas do instrumento de fluxo e as questões respondidas previamente pelos alunos para a pesquisa auxiliar.

Nas seções seguintes serão apresentados os diversos desdobramentos e ações empregadas durante a pesquisa. Na seção 4.1 História da pesquisa, o leitor visualizará como as reuniões ocorreram, informações sobre os professores, turmas e escolas que participaram do projeto. Será apresentada toda a dinâmica que resultou na idealização e adoção do fluxo como protoprincípio de design, assim como o desenvolvimento e aplicações da sequência didática. Na seção 4.2 Pesquisa auxiliar, o leitor encontrará detalhes sobre a finalidade, categorias e critérios adotados para a construção dos dados de análise desta pesquisa feita antes das aplicações. Na seção 4.3 Princípios de design o fluxo será definido e os demais princípios de design serão apresentados para explicar o desenvolvimento das atividades da sequência. Recomenda-se a leitura dessa seção com o volume II em mãos para a visualização do material respectivo às atividades. Na mesma seção o leitor também encontrará a descrição dos instrumentos empregados na coleta de dados, assim como as categorias criadas para a análise e seus respectivos critérios de categorização. 


\subsection{HISTÓRIA DA PESQUISA}

A descrição do desenvolvimento e aplicações será dividida em três períodos para facilitar a identificação das principais mudanças que ocorreram no grupo e nas etapas do trabalho. O primeiro período compreende o segundo semestre de $2011 \mathrm{e}$ trata do início, a produção e aplicação da sequência didática piloto e o desenvolvimento da ideia de fluxo. O segundo período acontece no primeiro semestre de 2012, relaciona-se com a finalização da sequência, o desenvolvimento do instrumento de fluxo como forma de produção de dados, a internacionalização da sequência e a aplicação da pesquisa auxiliar em contexto internacional. O terceiro período foi o período onde a maior parte dos dados foi construída, é constituído pela aplicação da pesquisa auxiliar e do instrumento de fluxo em contexto nacional no segundo semestre de 2012.

Antes de adentrar na história da pesquisa em si, é necessário apresentar sistematicamente os professores, escolas e turmas que se relacionaram com a pesquisa e constituíram a principal fonte de dados. No quadro 1 é possível observar os professores, turmas e respectivos períodos. A identidade dos professores foi preservada.

\begin{tabular}{|c|c|c|c|}
\hline \multicolumn{5}{|c|}{ Tabela de professores e turmas } \\
\hline Professor & $\begin{array}{c}1^{\circ} \text { período } \\
2^{\circ} \text { período }\end{array}$ & $3^{\circ}$ período \\
\hline Aplicador A & $\begin{array}{c}5 \text { turmas (a,b,c,d,e) } \\
3^{\circ} \mathrm{EM}\end{array}$ & $\ldots$ & $\begin{array}{c}\text { turmas } 3^{\circ} \mathrm{EM} \text { (BR3A } \\
\text { e BR3E) }\end{array}$ \\
\hline Aplicador B & 1 turma (f) $3^{\circ} \mathrm{EM}$ & $\ldots$ & $\ldots$ \\
\hline Aplicador $\mathrm{C}$ & 1 turma $(\mathrm{g}) 2^{\circ} \mathrm{EM}$ & $\ldots$ & $\ldots$ \\
\hline Aplicador D & 1 turma (h) $2^{\circ} \mathrm{EM}$ & $\ldots$ & 1 turma $2^{\circ} \mathrm{EM}$ (BR2E) \\
\hline Aplicador E & $\ldots$ & $\begin{array}{c}1 \text { turma Grade } 11 \\
\text { Grundkurs (DEGr) }\end{array}$ & $\ldots$ \\
\hline Aplicador $\mathrm{F}$ & $\ldots$ & $\begin{array}{c}1 \text { turma grade } 11 \\
\text { Leistungskurs (DELe) }\end{array}$ & $\ldots$ \\
\hline
\end{tabular}

Quadro 1: Lista de professores e turmas por período.

No ano de 2011, o Professor A tinha idade de 41 anos e larga experiência no ensino de Física. Mestre em Ensino de Ciências, era profissional do ensino há 16 anos, dedicou 15 deles ao ensino dessa disciplina. Lecionara 4 anos na E. E Alexandre de Gusmão sendo que possuía 5 turmas naquela escola no primeiro e terceiro período da pesquisa. Possui a característica de ser prestativo, calmo e focado na perspectiva de testar as ideias acordadas durante as reuniões. Suas aulas 
não foram diretamente acompanhadas pelo pesquisador, mas somente através das reuniões semanais e dos instrumentos de coleta de dados. A escola urbana se situa no centro da cidade de São Paulo, bairro do Ipiranga, em local arborizado e não muito movimentado. Próximo ao Museu do Ipiranga, grande parte dos alunos residem na comunidade do Heliópolis e seus arredores. O prédio é antigo e a escola possui tradição na região. Possui salas de aula comuns e laboratório de Física não utilizado. As cinco turmas do $1^{\circ}$ período forneceram diversas impressões e experiências importantes para a construção das atividades. As duas turmas do $3^{\circ}$ período (BR3A e BR3E) tiveram maior atenção pela instância de pesquisadores porque foram fonte de dados para o instrumento de fluxo. Ambas são turmas do último ano do Ensino Médio com 40 e 36 alunos matriculados respectivamente (entretanto a frequência inicial foi de 26 e 27 alunos em classe). Para ambas, a carga horária era de 2 aulas de 50 minutos por semana. Quando o professor A foi perguntado sobre o porquê da escolha destas últimas turmas, afirmou que a primeira era uma turma de melhor desempenho escolar e a segunda possuía maior afinidade pessoal.

O Professor B tinha aproximadamente 30 anos e em torno de 6 anos de experiência profissional atuando simultaneamente em outra escola e cursinhos preparatórios. Uma característica marcante de sua personalidade foi disposição e otimismo. A escola urbana E. E. Caetano de Campos - Aclimação se localiza na região central da cidade. A turma "f", do $3^{\circ}$ ano do Ensino Médio, possuía aproximadamente 30 alunos de classe média. O professor B teve participação ativa tanto nos encontros quanto na aplicação do curso piloto no primeiro período. Entretanto, se desligou completamente do grupo antes do início do segundo período por motivos pessoais não relacionados com a pesquisa.

O Professor C possuía 31 anos em 2011. Licenciado em Ensino de Física, teve naquele ano sua primeira experiência profissional em sala de aula na escola $E$. E. Victório Fornasaro. Possuía simultaneamente 11 turmas entre o primeiro e último ano do Ensino Médio. A escola urbana é localizada na Vila Sulamericana, Carapicuíba, região metropolitana de São Paulo. Segundo o Professor C a escola não tinha grande tradição e se encontrava numa região periférica e frequentada por alunos de famílias de classe média e média baixa. Teve grande participação no desenvolvimento das atividades e aplicou parte do curso piloto em 4 turmas do $2^{\circ}$ ano do Ensino Médio no primeiro período. No quadro 1 foi contabilizada apenas uma 
das turmas porque não foi obtido nenhum tipo de registro sobre as demais além de suas contribuições orais durante as reuniões. O Professor C não teve suas aulas acompanhadas diretamente pelo pesquisador, mas vídeos destas aulas foram feitos por ele mesmo. No perfil do Professor C se destacam a persistência e espírito de equipe.

O Professor D é jovem contando 26 anos em 2011 e 2 anos de experiência profissional, todos eles como professor de Física da E.E. Vicente Leporace. É licenciado em Ensino de Ciências e possui um perfil caracterizado pelo dinamismo e adaptação. A escola urbana se situa no distrito Jardim Ângela na zona sul da cidade de São Paulo. A rua é bem calma e o entorno do bairro apresenta grande movimentação contando com boa infraestrutura como supermercados e terminal de ônibus próximo. Entretanto a região tem assaltos frequentemente a noite, principalmente roubo de celulares de estudantes quando as ruas estão vazias. Os alunos são em sua maioria de classe média baixa. As classes são tradicionais contando com carteira e lousa. Houve dificuldade na utilização de material audiovisual quando solicitado em classe, entretanto a escola conta com salas dedicadas para a exibição de filmes e acesso a computadores. No primeiro período aplicou o curso piloto em uma turma e suas aulas foram gravadas. No terceiro período, possuía 9 turmas, das quais destacou 1 para a pesquisa por ter maior afinidade. A turma BR2E contava com 38 alunos matriculados, 23 inicialmente em classe, com carga horária semanal de 2 aulas de 50 minutos para o ensino de Física.

O interesse no estudo e implementação de sequências didática em contextos reais de aplicação tanto pelo NuPIC quanto pelo grupo de pesquisas da Professora Dr. Pospiech da Technische Universität Dresden propiciou uma colaboração internacional. A motivação teve início em colaborações anteriores entre os dois grupos, após um convite feito à professora para que aplicasse um curso no Brasil (Física Moderna e Contemporânea no Ensino Médio: A Experiência Alemã e os Desafios para a Implementação no Contexto Brasileiro) os interesses convergiram.

Desta forma, a sequência didática pôde ser aplicada por dois professores alemães em duas escolas alemãs públicas situadas na cidade de Dresden, Saxônia, mediante tradução do material didático. Deste modo, os dois professores $\mathrm{E}$ e $\mathrm{F}$ devem ser considerados de forma diferenciada tendo em vista a grande diferença de contextos de aplicação e a não participação destes professores no processo de 
desenvolvimento. Da mesma forma as turmas DEGr e DELe precisam ser compreendidas como parte de um sistema curricular próprio e diferente do brasileiro conforme pode ser visto no anexo 1 , volume II.

O Professor E ministrava, em 2012, aulas de Física e Ciências a mais de 10 anos e atualmente trabalha na escola Bertolt Brecht Gymnasium ${ }^{10}$ tendo sido laureado como um dos 10 melhores professores de Física da Saxônia. Ele ministrava 25 aulas por semana com duas delas para turmas de ensino especial no qual os estudantes recebem aulas de física em inglês. A capacidade de comunicação em inglês por parte do professor facilitou muito a comunicação de modo a compreender aspectos do sistema alemão de ensino e sua relação com os professores. A escola Bertolt Brecht Gymnasium situa no bairro de Johannstadt, próximo ao centro da cidade. Possui ótima infraestrutura contando com refeitório próprio, biblioteca e laboratórios de física equipados para o estudo de elementos de mecânica, marcenaria, eletrônica e costura e palco para teatro. Diversas alas do prédio estavam em obras durante o período de aplicação. A sala na qual o curso foi aplicado, era dedicada ao estudo de física, possuía armários nos fundos e bancadas com tomadas elétricas e fontes de alimentação de $12 \mathrm{~V}$ para os alunos. O professor contava com uma pequena lousa dupla deslisante, tela para projeção e uma grande bancada. Uma sala anexa à sala de aula continha diversos experimentos (muitos deles feitos pelo próprio professor) os quais possibilitava uma vasta gama de demonstrações em classe, o professor ainda tinha à disposição um armário e uma grande bancada (compartilhada por todos os professores) na sala de professores para o preparo de experimentos. É interessante observar que em um de nossos encontros, o professor afirmou utilizar muitos experimentos práticos durante suas aulas e que frequentemente construía todo tipo de demonstração quando perguntado sobre suas preferências metodológicas. Ele afirmou que a aplicação de um curso essencialmente teórico, como o de $\mathrm{RR}$, seria um desafio interessante e útil para ele, já que não possuía nenhum planejamento bem definido para este tipo de curso que está presente como opcional no currículo oficial alemão. A turma DEGr (Professor E) possuía 16 alunos do final da grade 11 (aproximadamente o segundo ano do Ensino Médio - ISCED $3^{11}$ ) do curso Grundkurs do Gyminasiale (curso destinado àqueles que seguiram o Gyminasiale - propedêutico para curso superior -

$10 \mathrm{http}: / / \mathrm{cms} . s n . s c h u l e . d e /$ bebe/willkommen/home/

11 De acordo com o International Standard Classification of Education (ISCED) 
mas não escolheram seguir carreiras científicas: 2 aulas de $45 \mathrm{~min}$ de física por semana $)^{12}$ sendo que eles não tiveram contato formal com conteúdos de RR até o momento da aplicação.

A Professora F, muito experiente, ministrava aulas de física a mais de 30 anos e atualmente contava com 23 aulas por semana. A escola Gymnasium Klotzsche $^{13}$ se situa no bairro Klotzsche, próximo a uma região fabril, mais distante do centro de Dresden. A sala de Física, onde o curso foi aplicado, segue o padrão escolar alemão constituindo-se de um ambiente dedicado com bancadas para trios equipadas com instalações elétricas, bancada para professora, uma pia, lousa e um televisor acoplado a um aparelho de DVD. Trata-se de uma escola mais simples, tradicional e antiga, com mais alunos do que a anterior. A turma DELe (professora F) era da grade 11 (equivalente ao 2 ano do Ensino Médio) ${ }^{14}$ foi composta 17 alunos e que seguiriam carreiras científicas (Leistungskurs). $O$ curso é destinado àqueles que seguiram o Gyminasiale e tem a característica de ser propedêutico ao curso superior. A carga horária para a disciplina de Física era de 5 aulas de $45 \mathrm{~min}$ por semana.

\subsubsection{Primeiro período}

O grupo teve início composto por 4 professores de escolas públicas diferentes da cidade de São Paulo, 2 mestrandos, 2 doutorandos e 3 professores doutores (incluindo neste número os coordenadores). Dois dos professores e dois pesquisadores já possuíam experiência na criação e aplicação de conteúdos de Física Moderna no NuPIC e foram convidados a integrarem o GrAFiE para facilitar o alinhamento tanto da metodologia de trabalho.

Os trabalhos iniciaram com a expectativa de se desenvolver, simultaneamente, várias propostas que abordariam conteúdos de FMC. As reuniões iniciais foram brainstorms direcionadas à exploração principalmente de conteúdos conceituais e procedimentais favoráveis à produção de sequências didáticas. Logo se percebeu que o volume de trabalho necessário ao desenvolvimento simultâneo seria impraticável surgindo a necessidade de focar numa única proposta.

12 Para maiores informações sobre o sistema educacional alemão, veja o anexo 1 presente no volume II.

13 http://www.gymnasium-klotzsche.de

14 De acordo com o International Standard Classification of Education (ISCED) 
Com base nos referenciais de pesquisa, na experiência que alguns integrantes possuíam junto aos temas de relatividade em sequências didáticas e pela possibilidade de colaboração com grupos de pesquisa no exterior que já se interessavam pela proposta, a escolha recaiu no desenvolvimento da sequência de RR contextualizado pelo tema Paradoxo dos Gêmeos. Esse assunto foi escolhido inicialmente devido sua complexidade conceitual, simplicidade algébrica e a disponibilidade de materiais para pesquisa.

Após algumas reuniões discutindo e procurando antecipar alguns dos obstáculos epistemológicos, didático-pedagógicos e detalhes críticos que caracterizariam a sequência didática, verificou-se que mesmo tendo o tema e as ideias em mãos, a abordagem inicial e encadeamento das atividades e a comunião dos objetivos específicos para se alcançar um objetivo global era nebuloso e não trivial. A ideia de fluxo da sequência didática iniciou seu desenvolvimento, ainda sem nome ou estruturação, numa estratégia adotada pela instância de pesquisa para guiar o desenho da estrutura com base num conjunto de condições de contorno sobre o conteúdo conceitual: o tema deveria ser o Paradoxo dos Gêmeos e estudos sobre o intervalo relativístico e a sequência deveria girar em torno de 10 aulas.

Esta estratégia interferiu construtivamente na produção das primeiras atividades trazendo maior clareza sobre a direção e o encadeamento que a sequência tomaria. Após diversas discussões sobre os assuntos que seriam abordados, foi decidido que o tema seria abordado apenas a partir do conceito de tempo, evitando-se o estudo dos efeitos sobre o espaço. Essa postura radical teve origem na busca pela definição precisa do que se pretendia ensinar e pela percepção de um dos grandes obstáculos à compreensão dos fenômenos relativísticos que é a compreensão do tempo relativo. Assim, o curso teria como objetivo-obstáculo transversal a emancipação da percepção cotidiana do tempo em direção à compreensão do tempo relativístico. Como o estudo do espaço tornaria a sequência muito longa, optou-se por contornar essa situação evitando-os.

As atividades evoluíram a partir de duas ideias básicas: contextualização inicial com abordagem sobre o conceito de tempo na Física e a construção de um modelo conceitual com base em experimento de pensamento. A primeira sequência de objetivos a serem alcançados junto aos alunos, acordada pelo grupo como forma de guiar o desenvolvimento, foi a seguinte: 
1) Conceituar tempo físico em relação a outros conceitos de tempo;

2) Entender o significado de dilatação ${ }^{15}$ do tempo;

3) Apreciar as condições necessárias para o tempo dilatar;

4) Ser capaz de representar eventos em um espaço-tempo geométrico;

5) Inferir e operar intervalos de tempo relativísticos em um diagrama espaço-tempo;

6) Compreender o paradoxo dos gêmeos (níveis 1 e 2)

7) Entender a dilatação do tempo no universo das partículas.

As constantes discussões sobre o sequenciamento das atividades convergiram para a evolução da primeira ideia de fluxo: um conjunto de afirmações/atividades por conectores em forma de questões, conforme pode ser visto nas figuras 2 e 3 . Tais conectores seriam responsáveis pela continuidade entre o final de uma atividade e o início da outra de forma a criar uma transição "lisa".

Proposta à partir das ideias apresentadas:

1) Diferentes formas de tempo [Ativ.1 - Gêmeos]

2) Realidade do tempo [Aviões/méson]

3) O tempo é sempre o mesmo

4) A solução de Einstein [éter, tempo, luz]

5) Relógio de luz [ estruturação do problema

6) Referenciais e eventos [Brás Cubas, Desenho Robilotta/Física]
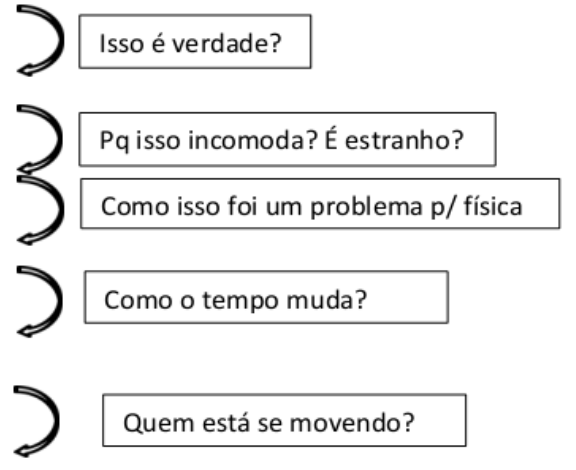

7) Formulação do 2우 Paradoxo

8) Invariante relativísticos [espaço-tempo como intervalo é Realidade]

9) Diagrama ict $\times x$ [Desenho Graciella]

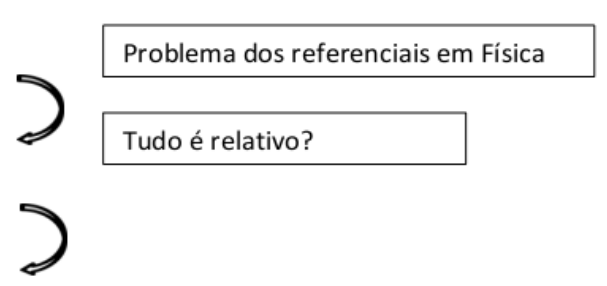

10) Discussão dos múons

Figura 2 - Primeira proposta de estrutura baseada em fluxo. A coluna da esquerda lista o que viria a ser a Moral da História para cada atividade. A coluna da direita lista a forma encontrada para conectar as atividades logicamente (setembro, 2011).

15 Até então o uso da palavra "dilatação" era corrente no grupo. A sequência privilegia a palavra "diferenciação".

16 Incluir uma explicação do paradoxo nivel 1 e nível 2 caso não haja nenhuma no texto. 
Essa estrutura foi bem recebida pelo grupo e evoluiu na tentativa de representar o melhor possível a estrutura intersubjetiva resultante das discussões. Nessa direção, estabilizou-se a ideia denominada moral da história, como a principal unidade que define, no fluxo, o papel de cada atividade. A moral da história é a principal mensagem transmitida por uma atividade. Na emergência de uma nova atividade, a moral da história deveria ser a primeira a ser definida e articulada com as demais. Somente depois da definição da moral da história, se iniciavam as discussões sobre os momentos da atividade.

Toda essa dinâmica era graficamente representada pelo diagrama de fluxo conforme a sequência era desenvolvida. Na figura 3 é possível ver o diagrama de outubro de 2011.

As quatro primeiras atividades foram feitas de modo totalmente coletivo com organização baseada em subgrupos responsabilizados por uma ou duas atividades as quais se preocupavam basicamente com duas perspectivas: a adequação ao contexto escolar e os possíveis obstáculos epistemológicos ou didático pedagógicos advindos das práticas propostas. O quadro 2 apresenta um esquema de evolução das atividades. Entretanto, a estratégia que trouxe benefícios também gerou efeitos colaterais, pois tais procedimentos exigiram uma grande quantidade de tempo adicional. A data máxima para que o curso piloto ocorresse foi mais ou menos definida levando em conta o tempo esperado para a aplicação das atividades já desenvolvidas e o final do ano letivo de 2011.

As aplicações começaram justamente no período de desenvolvimento das atividades finais, necessárias para a conclusão da sequência piloto. $O$ estreitamento do prazo gerou um sério problema na dinâmica de trabalho: não houve tempo para que as ideias discutidas partir da quinta atividade amadurecessem e fossem acomodadas pela coletividade.

Foram feitos estudos conceituais sobre a metodologia TLS, RR e os obstáculos epistemológicos e didático-pedagógicos, entretanto, até aquele momento, o grupo ainda não tinha superado o desequilíbrio interno em relação à intimidade com os conteúdos específicos da RR. A necessidade em abordá-los com maior ênfase associada à carga de trabalho extra das aplicações inaugurou uma dinâmica de produção e discussão diferente durante o preparo das atividades 5, 6 e 7. 


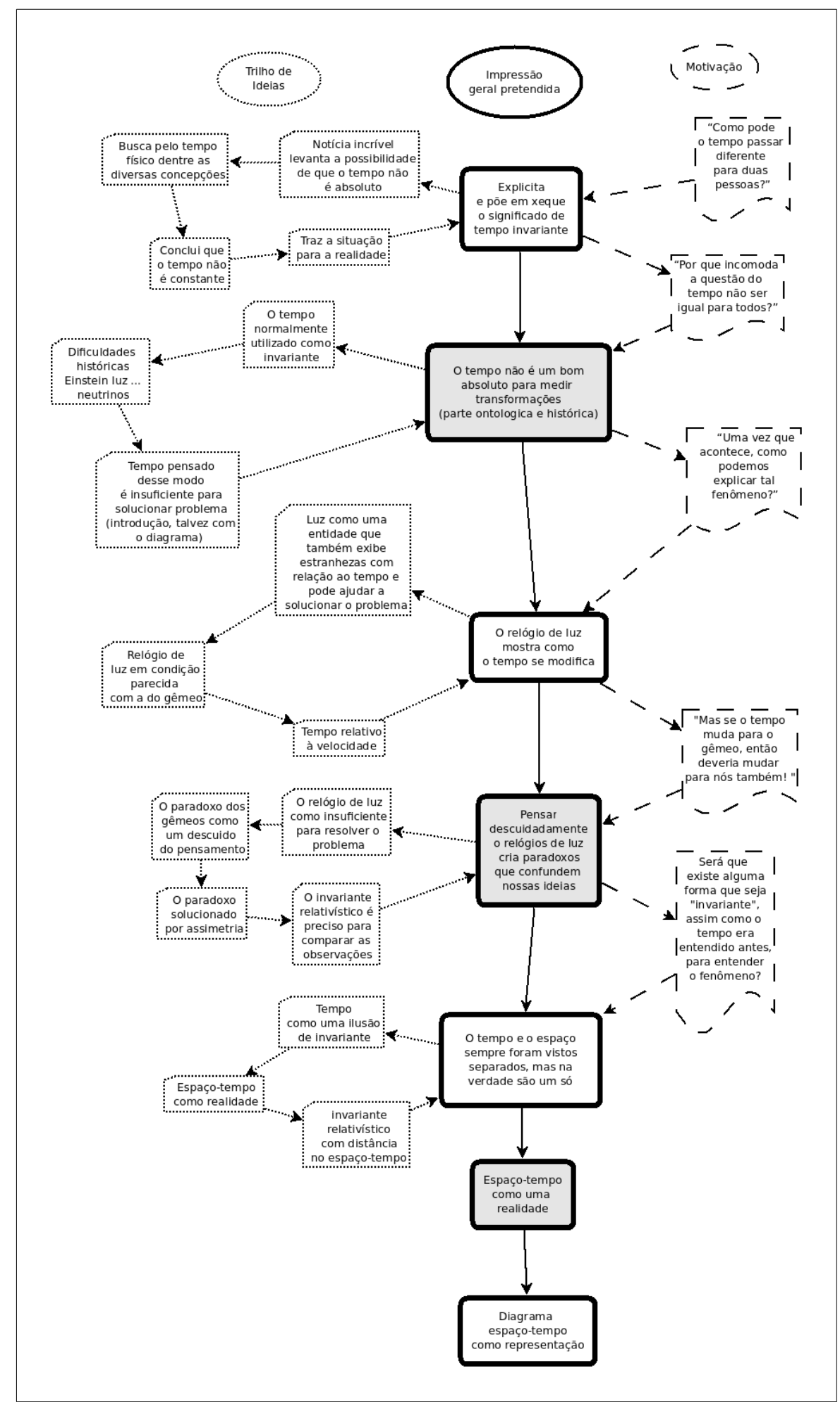

Figura 3 - Proposta de estrutura baseada em fluxo (outubro, 2011)

Essa nova dinâmica concentrou o esboço inicial das atividades na instância de pesquisa, procurando preservar a coletividade das discussões, decisões e validação. Isso de forma geral modificou a relação dos professores com o material, 
pois ainda que estivessem participando das reuniões, que suas sugestões estivessem sendo incorporadas e que as decisões fossem coletivas, houve um distanciamento no ato de fazê-la.

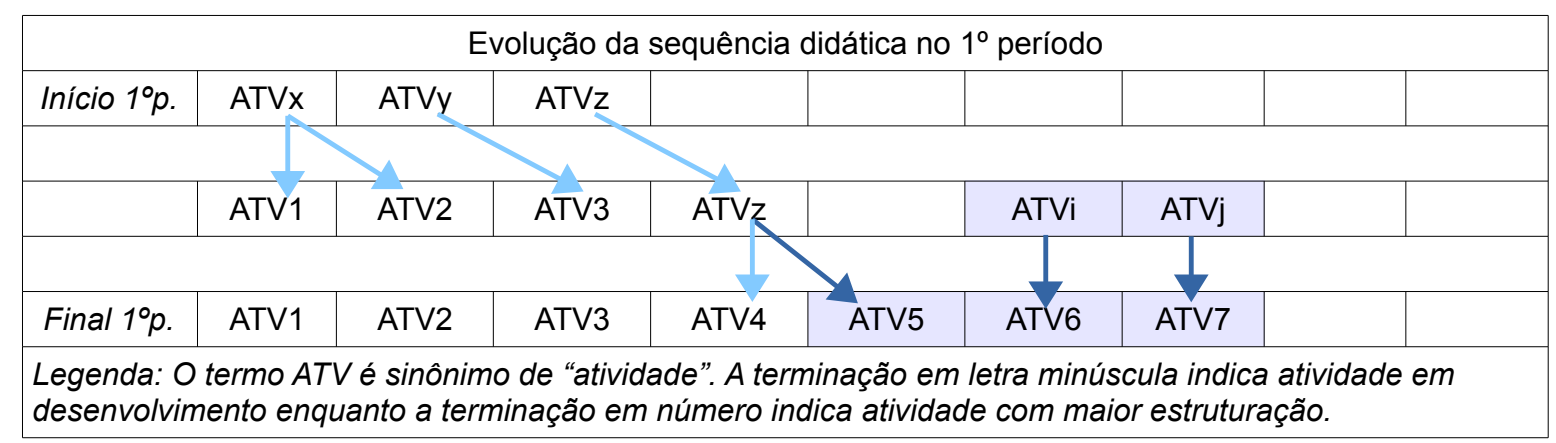

Quadro 2: Evolução da sequência no $1^{\circ}$ período. As três atividades iniciais se desmembraram em outras 5. As setas claras indicam a dinâmica de trabalho inicial e as setas escuras, a dinâmica de trabalho adotada quando se superpuseram o desenvolvimento às aplicações. As atividades com fundo escuro tiveram o esboço inicial vindos da instância de pesquisa.

A aplicação das atividades piloto ocorreram conforme pode ser observado no quadro 3. O professor A conseguiu chegar até a última atividade com grande dificuldade devido a um campeonato esportivo não previsto ao final do ano. As diversas turmas em que ministrava o curso precisaram ser gradativamente fundidas a partir das atividades 4 e 5 . Os professores B e D ministraram até o último dia de aula, mas tiveram aulas dispendidas em atividades administrativas da escola durante as aplicações ocasionando o não término das atividades devido à evasão escolar. O professor $\mathrm{C}$ iniciou tardiamente tendo em vista as atividades curriculares que estavam em andamento, não foi dada continuidade devido ao término das aulas.

\begin{tabular}{cc|cccccc|ccc}
\hline & Turmas & Pré-teste & \multicolumn{4}{c|}{ Primeiro bloco } & \multicolumn{3}{c}{ Segundo bloco } \\
PROF & CLASSES & PRT & ATV 1 & ATV 2 & ATV 3 & ATV 4 & ATV 5 & ATV 6 & ATV 7 \\
\hline Aplicador A & 5 turmas $3^{\circ} \mathrm{EM}$ & $\mathrm{a}, \mathrm{b}, \mathrm{c}, \mathrm{d}$ & $\mathrm{a}, \mathrm{b}, \mathrm{c}, \mathrm{d}, \mathrm{e}$ & $\mathrm{a}, \mathrm{b}, \mathrm{c}, \mathrm{d}, \mathrm{e}$ & $\mathrm{a}, \mathrm{b}, \mathrm{c}, \mathrm{d}, \mathrm{e}$ & $\mathrm{a}, \mathrm{b}, \mathrm{d}$ & $\mathrm{b}, \mathrm{c}$ & $\mathrm{b}, \mathrm{c}$ & $\mathrm{b}, \mathrm{c}$ \\
Aplicador B & 1 turma $3^{\circ} \mathrm{EM}$ & $\mathrm{f}$ & $\mathrm{f}$ & $\mathrm{f}$ & $\mathrm{f}$ & $\mathrm{f}$ & $\mathrm{f}$ & & \\
Aplicador C & 1 turma $2^{\circ} \mathrm{EM}$ & $\mathrm{g}$ & $\mathrm{g}$ & $\mathrm{g}$ & $\mathrm{g}$ & & & \\
Aplicador D & 1 turma $2^{\circ} \mathrm{EM}$ & $\mathrm{h}$ & $\mathrm{h}$ & $\mathrm{h}$ & & & & \\
\hline
\end{tabular}

As letras em minúsculo $(a, b, \ldots, h)$ representam as classes de aula dos respectivos professores aplicadores.

Quadro 3: Aplicação das atividades da versão piloto.

Ainda que a aplicação do curso piloto tivesse sido conturbada, o período foi rico em troca de ideias e discussões sobre os problemas e saberes experienciais. Diversas modificações e ajustes foram feitos no material e percebeu-se a necessidade de construir outras duas atividades para a aplicação completa da 
sequência didática.

O principal dado construído neste período foi a forma de desenvolvimento das atividades e a estrutura principal da sequência didática em si. A adesão geral do grupo ao princípio de manter os objetivos das atividades coesos a cada avanço na criação da sequência foi o lastro que permitiu que a ideia de fluxo se consolidasse.

\subsubsection{Segundo período}

Após as aplicações do curso piloto, o segundo período ocorreu no primeiro semestre de 2012. Os esforços foram direcionados ao aprimoramento das atividades 5,6 e 7 e material respectivo.

As aplicações piloto apontaram um grande obstáculo causado pelo não tratamento específico do conteúdo relacionado a mudanças de referenciais. A escolha em trabalhá-lo transversalmente gerara a necessidade de desenvolver uma atividade que apresentasse claramente o paradoxo presente no Paradoxo dos Gêmeos. Um segundo desafio foi a necessidade em criar um contexto para abordar o conceito físico de intervalo relativístico. Uma nova atividade foi desenvolvida a partir da última para criar essa contextualização e desenvolver habilidades em trabalhar com a unidade relativística de anos-luz. Essa dinâmica de inclusão pode ser observada no quadro $4 .^{17}$

\begin{tabular}{|c|c|c|c|c|c|c|c|c|c|}
\hline \multicolumn{10}{|c|}{ Evolução da sequência no $2^{\circ}$ período } \\
\hline Início $2^{\circ} p$. & ATV1 & ATV2 & ATV3 & ATV4 & ATV5 & ATV6 & ATV7 & & \\
\hline & ATV1 & ATV2 & ATV3 & ATV4 & ATV5 & ATVk & ATV7 & & \\
\hline Final $2^{\circ} p$ & ATV1 & ATV2 & ATV3 & ATV4 & ATV5 & ATV6 & ATV7 & ATV8 & ATV9 \\
\hline
\end{tabular}

Legenda: O termo ATV é sinônimo de "atividade". A terminação em letra minúscula indica atividade em desenvolvimento enquanto a terminação em número indica atividade com maior estruturação. As atividades com fundo escuro tiveram o esboço inicial vindos da instância de pesquisa.

Quadro 4: Evolução da sequência no $2^{\circ}$ período. As antigas atividades 6 e 7 foram renomeadas para atividades 7 e 9 e houve o surgimento de duas atividades intermediárias.

No segundo período, avanços importantes foram dados em direção à

17 Mais informações e características específicas sobre as atividades serão abordadas em seções posteriores. O leitor pode também acessá-las diretamente no anexo 3, presente no volume II deste trabalho. 
estruturação do conceito de fluxo. A representação do diagrama de fluxo se tornou consistente sendo plenamente reconhecido e ajustado coletivamente como um guia no desenvolvimento da sequência, sua versão final pode ser vista nas figuras 7,8 e 9 nas páginas 77, 78 e 79. Esse momento da pesquisa gerou uma série de tarefas majoritariamente centradas na instância de pesquisa. A materialização do instrumento de fluxo, o uso sistemático da pesquisa auxiliar, a tradução do material e as aplicações em contexto alemão foram as principais.

Ainda que em pesquisas DBR seja comum o planejamento prévio sobre os instrumentos de coleta, o instrumento de fluxo precisou ser feito depois da consolidação do diagrama de fluxo. Isso porque uma parte importante dele necessariamente se conecta diretamente às particularidades de cada atividades. Seria impossível a produção do instrumento antes da intenção didática estar materializada.

Nesse período, a pesquisa auxiliar foi efetuada para verificar quatro aspectos diferentes utilizando quatro questões distintas. O questionário foi distribuído aos alunos antes do início do curso. Optou-se analisar nesta dissertação apenas a terceira questão porque ela é a de maior interesse.

A colaboração que vinha sendo negociada junto ao grupo de pesquisas liderado pela Prof. Pospiech da Technische Universität Dresden, Alemanha, se confirmara nesse período promovendo uma série de demandas relativas à internacionalização. Inicialmente todo o material foi traduzido rusticamente para a língua inglesa para que fosse acessível ao grupo colaborador. A tradução para o alemão foi feita em conjunto e com maior cuidado para que fossem preservadas as ideias contidas no material.

A sequência didática foi aplicada por dois professores em duas turmas de escolas distintas conforme pode ser visto no quadro 5. Após o período de tradução, o principal foco dos trabalhos foram os encontros com os professores e as aulas, estas puderam ser acompanhadas em loco. Aquelas foram as primeiras aplicações completas da sequência didática, da pesquisa auxiliar e do instrumento de fluxo.

Tendo em vista as tarefas cotidianas dos professores alemães, foram feitas apenas uma reunião oficial e individualizada de $2 \mathrm{~h}$ para apresentar o material $\mathrm{e}$ expor, os objetivos, a metodologia e os instrumentos de pesquisa. Esse foi o tempo oficial para se conversar sobre o material. No caso do Professor E, a reunião foi feita 
sem a mediação do colaborador local tendo em vista seu domínio da língua inglesa. Vários outros encontros ocorreram antes e/ou após as aulas ministradas sendo muito mais destinados a ajustes, dúvidas ou troca de ideias. O curso foi todo ministrado em aulas duplas facilitando o ajuste das atividades. Entretanto a disponibilidade de apenas 8 aulas forçou a adaptação do material. As datas disponibilizadas foram muito espaçadas devido ao cronograma oficial saxão que previa exames específicos no mesmo período. O Professor $E$ iniciou a sequência aplicando as atividades 1 e 2 . Optou por descartar a atividade 3 como forma de adaptar o curso ao período disponível. Durante as atividades 4 e 5 , o professor $\mathrm{E}$ apresentou grande dificuldade em trabalhar o raciocínio lógico apresentado. Já na aula 3, retomou as passagens anteriores distribuindo um resumo das passagens matemáticas feitas de próprio punho aos alunos. Apresentou os vídeos da atividade 6 para auxiliar a compreensão do movimento relativo. Tratou apenas conceitualmente as atividades 8 e 9. Um campeonato escolar desfalcou a turma assim como ocorrera com as turmas do curso piloto no Brasil e o número de alunos caiu pela metade aproximadamente. A forma como foram organizadas as atividades pode ser vista no quadro 5 .

\begin{tabular}{|c|c|c|c|c|c|c|c|c|c|}
\hline \multicolumn{2}{|c|}{ Turmas } & \multirow[b]{2}{*}{ PA } & \multicolumn{4}{|c|}{ Primeiro bloco } & \multicolumn{3}{|c|}{ Segundo bloco } \\
\hline PROF & CLASSES & & \begin{tabular}{l|l} 
ATV 1 & ATV 2
\end{tabular} & ATV 3 & ATV 4 & ATV 5 & ATV 6 & ATV 7 & \begin{tabular}{l|l} 
ATV8 & ATV9
\end{tabular} \\
\hline Aplicador E & $\begin{array}{c}\text { Turma DEGr } \\
\text { Grade } 11 \\
\text { Grundkurs* }\end{array}$ & Ok & $\begin{array}{c}\text { Aula } 1 \\
\text { dupla: } 2 \times 45 \mathrm{~min}\end{array}$ & $\ldots$ & $\begin{array}{r}\mathrm{Al} \\
\text { dupla: }\end{array}$ & $\begin{array}{l}2 \\
45 \mathrm{~min}\end{array}$ & $\begin{array}{c}\text { Aula } 3 \\
\text { dupla: } 2 x \\
\text { 45min }\end{array}$ & $\ldots$ & $\begin{array}{c}\text { Aula } 4 \\
\text { dupla: } 2 \times 45 \mathrm{~min}\end{array}$ \\
\hline Aplicador F & $\begin{array}{l}\text { Turma DELe Grade } \\
11 \text { Leistungskurs* }\end{array}$ & Ok & $\begin{array}{r}\text { Aula } 1 \\
\text { dupla: } 2 \times 45\end{array}$ & & $\begin{array}{l}\text { Aula } 2 \\
45 \mathrm{~min}\end{array}$ & $\begin{array}{r}\text { A } \\
\text { dupla: }\end{array}$ & $\begin{array}{l}\text { la } 3 \\
\times 45 \mathrm{~min}\end{array}$ & $\begin{array}{l}\cdots \\
\cdots\end{array}$ & $\begin{array}{l}\text { Aula } 4 \\
45 \mathrm{~min}\end{array}$ \\
\hline
\end{tabular}

As atividades foram adaptadas

* com equivalência aproximada ao segundo ano do ensino médio - ISCED 3 (International Standard Classification of Education)

Quadro 5: Aplicação da versão completa na Alemanha.

Os encontros com a Professora $\mathrm{F}$ foram desafiadores uma vez que ela não se comunicava utilizando a língua inglesa devido sua formação escolar e profissional vinda do período soviético. Para a introdução ao curso, foi preparada uma apresentação bilíngue e, com o auxílio da professora Dr. Pospiech, orientadora, foi possível fazer uma tradução simultânea durante a apresentação. O agendamento, apresentação das perspectivas do curso, metodologia das aulas, diagrama de fluxo e entrega de todo o material ocorreram em dois encontros antes da aplicação. A 
professora se considerava uma profissional tradicional quanto ao ensino e, quando foi perguntada sobre o porquê participar do projeto, ela afirmou que pretendia adquirir novas ferramentas para abordar o tema e que estava interessada numa abordagem "mais qualitativa" uma vez que já havia aplicado "duas ou três" vezes esse tipo de conteúdo. Apesar de tímida no princípio, a professora pareceu mais à vontade após as apresentações e material em alemão. Nas aplicações, a professora adotou uma postura bem positiva e atenta aos tempos de aplicação. Na primeira aula, a disciplina e proatividade da turma tornaram possível a rápida leitura do texto introdutório que foi utilizado como contextualização do problema. O texto da atividade 2 foi mais encarado como um problema prático a ser solucionado e o da atividade 3 rendeu uma discussão entre os alunos. As atividades 4 e 5 foram trabalhadas com facilidade e a professora distribuiu um texto auxiliar sobre movimento inercial e referenciais antes de iniciar a atividade 6, que fora adaptada em forma de discussão com os alunos. Nas duas últimas atividades, a Professora $F$ esboçou dificuldade na compreensão do diagrama e pediu com alguma antecedência uma confirmação de suas próprias anotações. Foram disponibilizadas apenas 6 aulas para o tópico de RR conforme o quadro 5 .

\subsubsection{Terceiro período}

Durante o período de aplicações no exterior houve grande modificação no grupo brasileiro. Ele foi reorganizado e quando a pesquisa foi retomada em solo nacional, passou a contar com cinco integrantes: os professores $A$ e $D, o$ pesquisador e os dois professores doutores responsáveis. A redução do grupo a um subgrupo ocorreu por conta do desenvolvimento de outros projetos e devido ao momento de pesquisa caracterizado pelas discussões mais focadas no saber ensinado e ajustes finos vindos das aplicações.

Os encontros semanais se tornaram mais voltados à prática em classe e pouco voltados ao desenvolvimento do material. As constantes discussões feitas no pequeno grupo e a experiência prévia com 0 material permitiram maior entrosamento dos professores com o conteúdo favorecendo a focalização dos esforços nas dinâmicas próprias de cada professor e sala de aula.

As aulas iniciaram no final de agosto e se estenderam até o início de outubro 
de 2012. Nesse período duas turmas do professor A (BR3A e BR3E) e uma turma do professor D (BR2E) trabalharam as nove atividades, responderam à pesquisa auxiliar e ao instrumento de fluxo. A turma BR2E tivera quase todas as aulas gravadas em vídeo pelo pesquisador, já as turmas BR3A e BR3E não foram observadas diretamente por conta das dificuldades em conseguir as autorizações para as gravações na escola; seu acompanhamento foi feito pelos relatos do professor A e pelos instrumentos de fluxo que eram recolhidos. No quadro 6 é possível observar como se distribuíram as aulas durante as atividades.

\begin{tabular}{|c|c|c|c|c|c|c|c|c|c|c|c|}
\hline \multicolumn{2}{|c|}{ Turmas } & \multirow[b]{2}{*}{ PA } & \multicolumn{5}{|c|}{ Primeiro bloco } & \multicolumn{4}{|c|}{ Segundo bloco } \\
\hline PROF & CLASSES & & ATV 1 & ATV 2 & ATV 3 & ATV 4 & ATV 5 & ATV 6 & ATV 7 & ATV8 & ATV9 \\
\hline \multirow{2}{*}{ Aplicador A } & Turma BR3A & $\mathrm{OK}$ & 1 aula & 1 aula & 1 aula & 1 aula & 1 aula & 2 aulas & 2 aulas & 2,5 aulas & 1 aula \\
\hline & Turma BR3E & OK & 1 aula & 1 aula & 1 aula & 1 aula & 1 aula & 2 aulas & 2 aulas & 2,5 aulas & 1,5 aula \\
\hline Aplicador D & Turma BR2E & OK & 1 aula & 1,5 aulas & 1,5 aulas & 1 aula & 2 aulas & 1 aula & 2 aulas & 1,5 aula & 1 aula \\
\hline
\end{tabular}

Quadro 6: Aplicação da versão completa no Brasil.

A aplicação da sequência didática junto à turma BR2E ocorreu da forma esperada. Na primeira atividade o professor $\mathrm{D}$ optou por iniciar a atividade $1 \mathrm{com}$ uma exposição rápida da figura de Einstein, sua biografia e fama. Após distribuição e leitura do texto inicial, uma roda de discussões para tentar entender o que havia ocorrido com os gêmeos. O professor mediou a atividade buscando conduzi-la para argumentos científicos. Controlou a antecipação dos assuntos que seriam tratados no futuro, situação comum em discussões que exploram as concepções dos alunos.

O professor A, responsável pelas turmas BR3A e BR3E, fez uma abordagem direta em direção aos tipos de tempo com base no material do aluno da atividade 1 , nas estratégias presentes no material do professor e nos exemplos cotidianos aos alunos:

\footnotetext{
"Comentei sobre as possíveis soluções para que o tempo físico passasse diferente de um gêmeo para outro, como por exemplo a propaganda de um carro, no qual o marido é descongelado pela esposa, cuja diferença de idade ficou bem grande." (Professor A, relato da atividade 1 )
}

Um erro de planejamento na primeira semana de aula resultou na não coleta de dados sobre o fluxo da primeira atividade para ambos os professores. A preocupação com o início das aulas, as impressões de material, as discussões 
sobre como iniciar o curso levaram à desatenção do pesquisador com relação à data de entrega do instrumento de fluxo aos professores resultando numa lacuna nos dados da primeira atividade.

A atividade 2 foi iniciada pelo Professor A por meio de uma leitura compartilhada em que se distribuiu a leitura de cada um dos seis parágrafos do texto do aluno a seis alunos. A leitura de cada parágrafo foi discutida e houve maior atenção dedicada à passagem do tempo diferenciada entre referenciais. Foram tratadas as comparações de velocidade sugeridas no material e explicado superficialmente o que era um relógio atômico. Os alunos da BR3A responderam individualmente as questões propostas. Já na turma BR3E, o professor A optou por tratar as questões em trios e, durante as discussões, fez uma explicação que antecipava o formato de situações presentes somente em atividades que seriam tratadas muito adiante no curso:

\footnotetext{
“(...), mas uma aluna mencionou que não havia entendido nada. Assim, citei como exemplo se a aluna $X$ (outra aluna da sala) e o professor fossem irmãos gêmeos e ela pegasse um foguete tão rápido quanto o átomo do exemplo do texto e viajasse por dois dias e retornasse, qual seria a diferença deidade? Alguns acertaram a resposta, mas outros ainda estavam em dúvida." (Professor A, atividade 2)
}

O professor D, por sua vez, apresentou a atividade 2 na BR2E como um caso semelhante ao dos gêmeos na atividade 1, mas que desta vez seria real. Durante a leitura do texto, foi solicitado que os alunos grifassem o que lhes chamassem a atenção. Questões sobre o que seria um relógio atômico também surgiram para essa turma. O professor direcionou as respostas para as noções de tempo absoluto e relativo e iniciou as discussões relacionadas às questões. Ao responder a primeira questão, cerca de $70 \%$ da turma conseguiu associar o átomo em movimento com o irmão gêmeos da atividade 1. A principal discussão na aula foi com relação ao próprio experimento presente no texto. 
ambos os átomos estão em movimento, então qual a resposta correta? Aqui entrei um pouco nas definições de velocidades relativas." (Professor $\mathrm{D}$, atividade 2 )

Por falta de tempo na primeira aula da atividade, o professor $D$ optou por tratar a última questão na aula seguinte. A questão 4 do material do aluno se apresentou confusa e o professor conseguiu contornar e explicar situação do movimento relativo entre os dois átomos.

$\mathrm{Na}$ atividade 3, o Professor D utilizou uma aula discutindo o texto Entrevista com Einstein e Newton, mas perdeu 10 minutos de aula devido a uma interrupção administrativa da escola. Assim a discussão sobre a entrevista com Einstein, a constância da velocidade da luz e a discussão das questões ficaram para a aula seguinte. $O$ professor $D$ pediu que as questões fossem respondidas em grupo passando por cada aluno para tratar dúvidas individuais, ao final houve uma discussão com o grande grupo. $O$ professor $D$ relatou que não houve dificuldade com as questões porque eram parecidas e reconhecíveis no corpo do texto da entrevista.

Já na atividade 4 o professor $\mathrm{D}$ precisou fazer uma rápida revisão dos assuntos já vistos porque a sequência ficara parada por duas semanas por conta de um feriado. A atividade 4 efetivamente inicia com o questionamento sobre o porquê da diferença temporal para corpos em movimento. Como a atividade 4 apresenta um roteiro para facilitar a construção do modelo relativístico, o professor optou por ler coletivamente e discutir as questões em partes. As três primeiras questões não representaram grandes dificuldades para os alunos.

Nas questões seguintes, a complexidade da situação proposta começou a se revelar quando os alunos precisaram compreender os dois pontos de vista em que o R-Luz fora observado. O professor $D$ optou por uma abordagem que reproduzisse em classe a visualização similar ao do esqueitista presente no material. Utilizando uma carteira e um celular com câmera, um aluno segurou o celular e narrou o que via na tela de modo fazer compreender o que estava sendo representado naquelas figuras. 
Skatista, percebi que os alunos não tiveram, no primeiro momento, abstração para compreender que, para o Skatista, quem estava em movimento, na verdade é o R-luz.

Tentando reverter esta situação foi feito um experimento em sala de aula onde o aluno ficou sentado na cadeira em movimento e visualizava o "mundo externo" somente pela câmara do celular. Por meio da demonstração, grande parte dos alunos (não posso afirmar que todos!) perceberam que, para o Skatista, quem se movia era o Rluz.." (Professor D, atividade 4)

A partir dessa explicação central, não houve dificuldade com relação à matemática necessária para responder as questões seguintes, mas deve-se ressaltar que o Professor D optou por fazer uma revisão de matemática antes do início da sequência didática de relatividade. Não houve grande interferência do professor durante as discussões relativas às questões 7, 8 e 9. É importante indicar que ao final da atividade 4 , o professor $D$ esqueceu o instrumento de fluxo e, tendo em mãos apenas um exemplar, escreveu a $1^{\text {a }}$ etapa do instrumento diretamente na lousa para que os alunos respondessem, entretanto deixou de escrever a $2^{\mathrm{a}}$ etapa criando uma lacuna nos dados sobre a fluência da turma BR2E.

O Professor A iniciou a atividade 4 discutindo com os alunos as limitações dos experimentos de pensamento. As questões foram respondidas individualmente $\mathrm{e}$ uma pequena discussão se seguiu ao final de cada grupo de questões. Os alunos apresentaram dificuldade em compreender os referenciais cujo tempo é próprio ou diferenciado. Essa dificuldade era esperada e seria atacada na atividade seguinte. $O$ professor A optou por antecipar alguma discussão sobre isso nessa atividade. Abaixo um trecho afirmado pelo próprio professor.

\footnotetext{
"Vários alunos associaram essa diferença de tempo com o movimento, mas havia uma certa confusão com o significado desses valores - alguns afirmaram que o tempo passou mais devagar para quem estava parado e outros o contrário. Expliquei que para o skatista, que estava numa velocidade muito grande, o tempo ${ }^{18}$ demorou mais para passar em relação a alguém parado." (Professor A, atividade 4)
}

Antes do início da atividade 5, foi previsto um tempo para explicar como deveriam ser feitos os vídeos que seriam utilizados na atividade 6 . Esse tempo, para

\footnotetext{
18 Tempo entre os eventos produzidos pelo R-Luz.
} 
fins práticos, foi contabilizado no quadro 6 como sendo parte da atividade 5 . Como pode ser visto no material do professor da atividade 5 , foi incluída uma aula extra complementar o tempo para essa explicação, a modificação no material foi feita logo após o problema ter sido detectado.

O Professor D tinha planos em utilizar apenas o início da aula para explicar a produção dos vídeos. Entretanto, acabou por dispender quase uma aula completa para indicar aos alunos onde deveriam focar a atenção e como poderiam ser produzidos os vídeos. Em virtude da complexidade da tarefa e de problemas técnicos com o equipamento multimídia, o professor procurou garantir a compreensão da tarefa publicando dos vídeos em seu blog pessoal. A atividade 5 em si, seguiu de forma tradicional pelo Professor D, ele fez a leitura explicando as "rasuras" presentes no texto do aluno fictício, proposto pela atividade, e sistematizou as ideias desenvolvidas na atividade 4 sem grande enfoque nas equações.

Já o Professor A abordou a atividade 5 por meio de uma leitura coletiva e solicitou aos alunos que anotassem as palavras rasuradas no texto. Seguiu-se uma discussão sobre as correções feitas pelo aluno fictício e sobre o conceito de referencial próprio e diferente. O professor não explorou a passagem matemática referente ao gama presente na relação relativística. A apresentação dos vídeos e explicações para a atividade 6 foram feitas ao final da aula destinada à atividade 5 , tanto para a turma BR3A quanto para a BR3E. As mídias também foram disponibilizadas na web em rede social de livre acesso.

A atividade 6 teve grande empenho da turma BR2E e a produção dos vídeos trouxe grande satisfação para o professor D. Os vídeos foram exibidos e o jogo, proposto na atividade, fluiu com entusiasmo permitindo ao professor explicar como ocorre o Paradoxo dos Gêmeos com exemplos tirados das ideias que os alunos apresentaram durante o quiz proposto no material. Como o professor utilizou duas aulas para a atividade 5, ele teve acesso aos vídeos com uma semana de antecedência da apresentação em classe. Isso permitiu melhor preparo das discussões que seriam fomentadas em sala de aula. O quiz seguiu como esperado, os alunos votaram no vídeo que gerara maior dúvida quanto à forma filmada, ou seja, no que se mostrou mais eficiente em explorar a relatividade do movimento conforme solicitado. 


\begin{abstract}
"Passava o vídeo e deixava um tempinho para eles discutirem quem estava em movimento e quem estava parado;

Perguntava aos lideres e ao responderem, marcava na lousa se os grupos achavam que era o objeto ou a câmera, está sequência foi feita em todos os vídeos, ao termino da atividade, foi feita uma discussão de quem foi o melhor vídeo e ficamos na dúvida quem deveria vencer (...) Voltamos à sala e discutimos rapidamente a ideia de referencial, já que uma situação pode ser vista de perspectivas diferentes." (Professor D, Atividade 6)
\end{abstract}

A atividade 6 foi desenvolvida depois do curso piloto e leva em consideração que as duas atividades anteriores tinham caráter pouco dinâmico para os alunos. $O$ Professor $\mathrm{D}$ considerou o formato da atividade 6 um surpreendente incentivo aos alunos.

\footnotetext{
"Para concluir, esta aula foi bastante dinâmica e saiu um pouco da rotina já que os alunos tiveram que produzir algo que considerei muito profissional e me surpreendi." (Professor D, Atividade 6)
}

A aplicação da atividade 6 pelo Professor A foi dificultosa. A maior parte dos grupos tanto da turma BR3E quanto da BR3A não fizeram os vídeos para a aula combinada revelando uma falha na comunicação ou desmotivação. Para a turma BR3E, o Professor A utilizou a primeira aula para dividir os grupos, levar os alunos na sala de vídeo e explicar a dinâmica do quiz. Entretanto, mesmo na aula seguinte, separada em uma semana da anterior, apenas um dos grupos de alunos se prontificaram a fazê-lo. Não houve deslocamento para a sala de vídeo e foi utilizado o computador pessoal do professor para a exibição. O professor fez uma enquete rápida sobre o vídeo mostrado e o utilizou como recurso para abordar a noção de referencial e explicar o Paradoxo dos Gêmeos.

A atividade 7 foi considerada de difícil aplicação por ambos os professores e com muita dificuldade foi completada. O momento em que é solicitado desenhar as situações em que os eventos ocorriam tomou muito tempo e a atividade se estendeu por duas aulas em todas as turmas. Como sugestão do professor $A$, foram utilizadas cartolinas em vez da lousa, conforme é sugerido pelo material. Isso permitiu maior mobilidade com os desenhos durante a investigação proposta na atividade. 
O professor A optou por pedir aos alunos que indicassem a hora de cada evento e desenhassem os principais eventos diretamente em folhas de sulfite em vez de desenhar nas folhas já preparadas para a atividade, fez isso para ambas as turmas BR3E e BR3A. Os alunos demonstraram dificuldades em compreender e fazer essa parte da atividade levando o que levou ao consumo uma aula completa. Ao final da atividade 7, o professor leu a solução do Brás Cubas.

O professor $D$ também utilizou uma estratégia similar no gerenciamento dos desenhos e para ganhar tempo distribuiu cartolinas que seriam expostas posteriormente.

\footnotetext{
"Pensou-se na cartolina porque fiquei preocupado de não dar tempo dos alunos desenharem na folha de papel e depois reproduzi-la no quadro e desenhando tudo na cartolina ganhávamos tempo e os alunos fariam uma coisa só." (Professor D, atividade 7)
}

$\mathrm{Na}$ segunda aula, o Professor D chamou os grupos à lousa para compartilhar os seus respectivos eventos. Foi construída a linha de mundo com as informações apresentadas pelos grupos. A dinâmica da atividade não foi bem sucedida devido ao grande número de informações simultâneas que a sala precisava lidar, o Professor $D$ afirmou que ele mesmo teve dificuldade em se localizar na atividade. A leitura da perspectiva final do personagem Brás Cubas foi feita rapidamente no início da aula seguinte.

O Professor A trabalhou a atividade $8 \mathrm{em}$ um pouco mais de duas aulas. A leitura do texto foi feita coletivamente de modo que grande tempo foi gasto para se compreender bem a situação proposta no texto. O professor solicitou que os alunos respondessem as questões e apenas depois discutiu-as em classe. A noção de distância em anos-luz foi abordada e o professor A terminou a aula mostrando porque o Paradoxo dos Gêmeos era falso. A última aula sofreu interferências de assuntos administrativos sobre formatura tanto para a turma BR3A quanto para a BR3E.

O Professor $\mathrm{D}$ leu o texto sobre o caminhoneiro relativístico indicando que o tratamento das unidades de medida em anos-luz poderiam ser vistas em seu próprio blog. Deu maior atenção ao parágrafo 6 do texto que trata sobre a impossibilidade 
de dois referenciais, com velocidade relativa, concordarem quanto ao tempo entre dois eventos: mostrou como o problema poderia ser representado esquematicamente e também matematicamente. Pediu aos alunos que respondessem as questões, mas a questão cinco foi respondida coletivamente.

$\mathrm{Na}$ atividade 9 , o professor A e D optaram por fazer a leitura, discussão do texto e a abordagem das questões de forma coletiva. Ambos utilizaram a atividade como uma forma de sistematizar as ideias e conclusões sobre o intervalo relativístico.

O professor A optou por uma finalização mais focada na resolução das questões da atividade 9 . Ao final da aula, o professor percebeu que esquecera as fichas do instrumento de fluxo resultando numa lacuna nos dados desta atividade.

A finalização da sequência didática feita pelo professor $D$ foi uma discussão do tipo "perguntas e respostas" onde todos participaram colocando suas dúvidas e comentários.

Durante a aplicação da sequência, os professores externalizaram a necessidade de instrumentos de avaliação. Tais instrumentos foram criados, mas não sistematicamente postos em prática. Os respectivos textos são: "Avaliação Intermediária" e "Temas para seminários". O uso do instrumento de fluxo como instrumento de feed back para os professores empregado durante a aplicação. Mas foi somente no final do $3^{\circ}$ período que as questões da primeira etapa do instrumento $^{19}$ foram dispostas ao final de cada atividade como um instrumento de avaliação tradicional. Os textos "Introdução - Paradoxo dos Gêmeos" e "Distribuicao de Tarefas após ATV4" também foram incluídos no material após a aplicação. Todos eles possuem a intenção de preparar melhor o professor que desejará utilizar a sequência autonomamente. Entretanto, tais textos presentes devem ser desconsiderados durante a análise desta pesquisa, porque são materiais não existentes durante as aplicações.

\subsection{PESQUISA AUXILIAR}

A pesquisa auxiliar (PA) é constituída pela análise de uma das quatro 
questões de um questionário relacionado à sequência didática. Os alunos responderam as questões antes do início da sequência de modo que o tempo necessário para respondê-las girou em torno de 20 minutos, tanto no Brasil quanto na Alemanha. O questionário foi feito sem a pretensão de analisar os conhecimentos formais que os alunos possuíam antes da sequência, procurou evidenciar aspectos pontuais sobre algumas concepções físicas e algumas interpretações a respeito do formato do próprio material que seria utilizado durante o curso.

A partir do questionário completo, optou-se por analisar apenas a terceira questão porque ela possui semelhança metodológica com a adotada na construção do instrumento de fluxo e porque suas conclusões se relacionam mais diretamente à perspectiva da sequência didática a qual considera os fenômenos naturais como independentes de observadores. Deste modo, será feita apenas uma descrição superficial das demais para melhor compreensão do contexto de aplicação, o questionário completo pode ser visto no anexo 2 , volume II.

A primeira questão, de forma alternativa, é baseada no trabalho de Karam, Cruz, \& Coimbra, 2006 e procurou levantar um perfil conceitual do conceito de tempo dos alunos segundo uma categorização dividida entre realismo ingênuo, empirismo, racionalismo tradicional e surracionalismo. A ideia foi levantar informações sobre como o aluno compreende a noção de tempo antes do início a sequência. A segunda questão esteve diretamente relacionada a uma representação utilizada no material. A ideia foi tentar verificar se o aluno conseguia associar movimentos bidimensionais às representações estáticas, como as utilizadas na atividade 4 e 5 (ver anexo 3, volume II) de modo que a construção do dado foi feita com base em trajetórias desenhadas pelos alunos. A terceira questão é explorada em detalhes e será tratada adiante. A quarta questão versa sobre as habilidades matemáticas do aluno. Trata-se de uma situação onde os acontecimentos embaralhados são associados a coordenadas de espaço e tempo. Os alunos deveriam localizá-los em um gráfico, conectar os pontos para montar uma conclusão sobre o que aconteceu tanto graficamente quanto algebricamente. Procurou-se verificar as dificuldades na interpretação e passagem de coordenadas para os gráficos.

Compreende-se que o contexto de classe tenha influenciado as respostas, porque o aluno ao responder o questionário estava sentado em sala de aula, estudando conteúdos de ciências e ciente de que em breve seria ministrado um 
curso sobre relatividade. Além disso, ainda que avisados do contrário, é comum que os alunos considerem o questionário como uma espécie de teste valendo pontos, isso modula as respostas na direção de fazê-las se enquadrarem em expectativas que os alunos acreditam existir naquele momento. Essas interferências, mesmo que não detectáveis no nível desta pesquisa, são esperadas e consideradas como elementos caracterizadores normais dos ambientes escolares.

\subsubsection{Estrutura e critérios de análise da terceira questão da pesquisa auxiliar}

A terceira questão objetiva verificar como os alunos compreendem a ocorrência de um fenômeno natural de forma geral. A ideia central é perguntar se um acontecimento está ou não condicionado à presença de observadores. Para isso, o aluno se depara com duas afirmações seguidas respectivamente por duas e três alternativas. As alternativas apresentam explicações curtas em forma de afirmações as quais procuram modular as respostas dos alunos em linhas de raciocínio preestabelecidas. Com base na categorização, verifica-se se a quantidade de alunos que são mais ou menos inclinados a considerarem que fenômenos naturais como independentes da observação de alguém.

Não era objetivo o levantamento das diferentes perspectivas dos alunos, mas sim verificar sua interação com as perspectivas apresentadas.

$\mathrm{Na}$ figura 4 é possível observar a diagramação e estrutura da questão 3 . A versão alemã desta ficha possui ligeira diferenciação no texto e diagramação que não altera de forma relevante sua interpretação e análise dos dados.

A questão foi formulada para gerar respostas duplicadas, pois se trabalha com a hipótese de que a estrutura dupla ajuda o aluno a compreender com mais clareza o núcleo das indagações e, ao mesmo tempo, permite melhor interpretação das respostas apresentadas.

O enunciado apresenta uma instrução sobre como executar a tarefa. A ideia é que o aluno escolha, dentre as opções dadas, aquela que julgue melhor explicar a respectiva afirmação. As afirmações foram feitas com linguagem cotidiana para evitar direcionamento científico na resposta a ser dada. O único direcionamento esperado foi o de contexto de classe. 
Escolha uma das explicações que você considere que seja a melhor em cada caso e explique o porquê da sua escolha.

Com céu aberto ao meio dia, o Sol brilha para todos!

$(\downarrow)$ Isso acontece para todos, pois o brilhar do Sol independe das pessoas.

( ) Isso acontece somente para quem está sob o Sol, pois quem está fechado dentro de casa não percebe seu brilho naquele momento.

O que te levou a fazer essa escolha?

Prave o sol nāo depende de ninguém pora bewencer. ele apenas bruena, nás importa of momento ou Situricon

Um animal nasce no meio de uma selva

(XIsso acontece para todos, mesmo que não vejamos o filhote.

( ) Isso se tornará um acontecimento quando alguém localizar o filhote na selva

( ) Isso acontece somente para o animal e sua mãe, pois ninguém mais sabe sobre o nascimento.

O que te levou a fazer essa escolha?

Poraue de qualquer formar a fiehote nascerá

Figura 4 - exemplo da questão 3 respondida por um aluno da turma BR3E.

A primeira afirmação, "Com o céu aberto ao meio dia, o Sol brilha para todos!", possui o fenômeno central associado ao verbo "brilhar". Esse, por sua vez, está relacionado a algo astronômico, longe de ser controlado, mas acessível aos observadores com facilidade. A segunda afirmação, "Um animal nasce no meio de uma selva.", possui o fenômeno associado ao verbo "nascer". Diferentemente do caso anterior, o fenômeno está relacionado a algo no meio da selva, o qual poderia ocorrer em segredo. A ideia de nascer também evoca um caráter de maior afetividade.

As respectivas alternativas possuem um formato de texto repetitivo de modo que ambos os fenômenos são representados pela palavra "acontecimento" ou suas derivações. Isso foi feito para induzir o leitor ao reconhecimento de uma unidade na interpretação das duas etapas apresentadas. As cinco respostas na forma de alternativas foram construídas com base em dois tipos de explicação, conforme apresentado no quadro 7 abaixo. 
Explicações tipo 1

Coerência: Sugere que fenômenos naturais fazem sentido independentemente da observação de alguém.

Alternativa A: (_) Isso acontece para todos, pois o brilhar do Sol independe das pessoas.

Alternativa C: (_) Isso acontece para todos, mesmo que não vejamos o filhote.

\section{Explicações tipo 2}

Coerência: sugere que fenômenos naturais fazem sentido se estiverem associados à observação de pessoas.
Alternativa B: (_) Isso acontece somente para quem está sob o Sol, pois quem está fechado dentro de casa não percebe seu brilho naquele momento.

Alternativa D: (_) Isso se tornará um acontecimento quando alguém localizar o filhote na selva.

Alternativa E: ( $)$ Isso acontece somente para o animal e sua mãe, pois ninguém mais sabe sobre o nascimento.

Quadro 7: Tipos de explicação apresentadas na $3^{a}$ questão. A coerência define cada tipo de explicação.

Essa estratégia visa ampliar a percepção sobre o significado de fenômeno natural para além das particularidades de cada afirmação e, ao mesmo tempo, restringir as interpretações dos alunos aos dois tipos de explicação existentes. Ainda que a escolha e justificativa do aluno venham de associações semânticas e contextuais muito mais complexas e que vão além das opções dadas pelo instrumento, trabalha-se com a hipótese de que a escolha dada sempre revelará o critério de "melhor explicação" utilizado pelo aluno.

Este instrumento não possui nenhum mecanismo para verificar se o aluno compreendeu bem o texto ou a operacionalidade exigida para se respondê-lo. Entretanto condições de contorno minimizam tais possibilidades: 1) Procurou-se produzir questões diretas, que indicassem as interpretações esperadas sem perda de naturalidade. 2) Todos os sujeitos são alunos de Ensino Médio, os quais acreditamos que, em sua maioria, compreendam a linguagem e a instrução dada. 3) As respostas foram dadas em sala de aula possibilitando esclarecimentos gerais sobre as instruções.

Para a categorização das respostas da terceira questão foram desenvolvidas duas dimensões. A primeira dimensão é denominada dimensão de continuidade e tem o objetivo de verificar como o aluno mantém ou não a mesma interpretação sobre as afirmações presentes na ficha.

A segunda dimensão é denominada alinhamento e divide as respostas em categorias que indicam alinhamento ou não à perspectiva pretendida na da sequência didática. Esta dimensão utiliza parte das categorias da dimensão de 
continuidade com olhar modificado.

\subsubsection{Dimensão de continuidade}

As categorias da dimensão de continuidade separam as respostas em convergentes ou divergentes e em coerentes ou incoerentes tendo por base a perspectiva e interpretação dos tipos de explicação apresentados anteriormente. Existe ainda uma categoria que comporta as respostas incompletas ou respondidas incorretamente.

A categorização é feita a partir das combinações das alternativas escolhidas pelos alunos e suas justificativas conforme o seguinte critério: Considera-se que alternativas de uma resposta são convergentes entre si se ambas as escolhas seguirem um único tipo de explicação. Os alunos que responderam a questão sinalizando alternativas de tipos distintos possuem respostas consideradas divergentes.

A atribuição de categorias às justificativas é, por sua vez, subjetiva e muito dependente da percepção do pesquisador. Considera-se coerentes com as alternativas as justificativas que apontam para as explicações do tipo correspondente. Por outro lado, serão incoerentes as justificativas que utilizam explicações que difiram do tipo relacionado à alternativa escolhida.

É importante observar que o critério de coerência/incoerência não indica que a resposta é incoerente ou coerente de forma geral. As categorias são referenciadas pelos tipos de explicação as quais caracterizam a relação justificativas/perspectiva adotada pela pesquisa de forma geral.

A figura 5 apresenta a forma geral adotada para aplicar os critérios durante a categorização. Deste modo, os critérios de categorização levam a quatro categorias. 


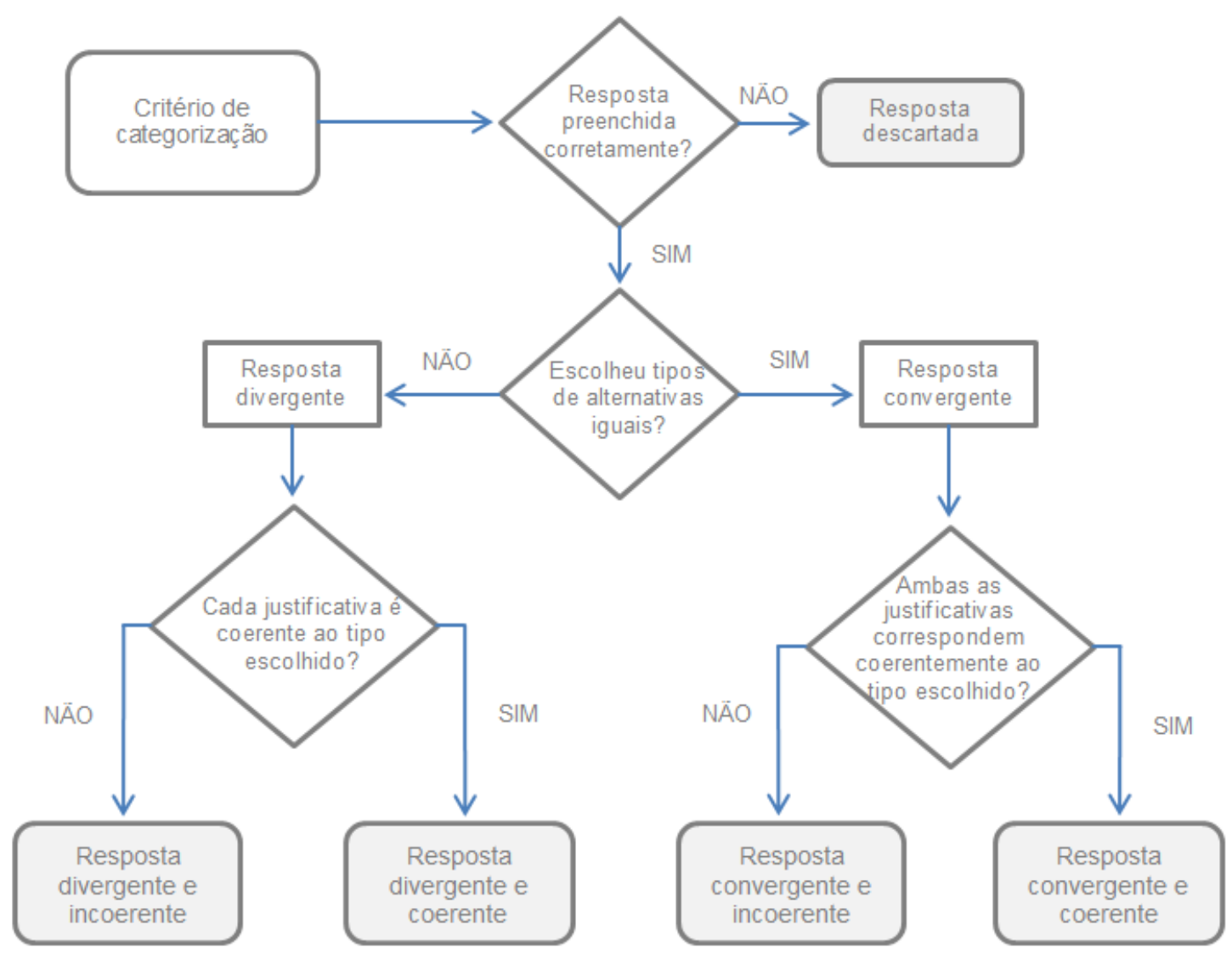

Figura 5: Procedimento geral de categorização. As categorias resultantes são representadas pelas caixas cinzas.

Respostas convergentes e coerentes (Conv\&Coer): São as respostas que apresentam o mesmo tipo de explicação para as duas etapas de modo que suas justificativas sejam coerentes aos tipos de explicação escolhida. Utilizando a figura 4 como exemplo, o aluno escolhe as alternativas $\mathrm{A}$ e $\mathrm{C}$ e faz suas justificativas. Como ambas são do tipo 1 , então sua resposta será categorizada como convergente. Tanto a justificativa da alternativa $A$ quanto a da $C$ são coerentes com a noção de coerência do tipo 1 , conforme pode ser visto no quadro 7 , indicando uma resposta coerente. Deste modo, aquela resposta é coerente e convergente. Exemplos de cada uma das categorias poderão ser verificados na seção de Análise.

Respostas divergentes e coerentes (Div\&Coer): são aquelas que não mantêm os mesmos tipos de explicação para ambas as afirmações, mas permanecem com justificativas coerentes às respectivas respostas. Como exemplo, a resposta de um aluno da turma BR3A. Na primeira etapa escolhe a alternativa B e justifica coerentemente com o tipo 2 dizendo "Pois, dependendo do ambiente que 
você esteja não se observa o brilho do sol, principalmente se estiver em um local muito escuro e fechado." $\mathrm{Na}$ segunda etapa, escolhe a alternativa $\mathrm{C}$ e justifica coerentemente com o tipo 2 escrevendo "Pois, mesmo que não vejamos o nascimento do filhote, não é uma coisa impossível, e isso ocorre e acontece para todos nós.". Como as escolhas são divergentes, mas as alternativas foram justificadas coerentemente, a categorização atribuída foi Dive\&Coerente.

Respostas convergentes e incoerentes (Conv\&Incoer): são aquelas em que os alunos escolhem o mesmo tipo de alternativa, mas não as justificaram com base nos tipos 1 ou 2 exclusivamente. Como exemplo, na resposta de um aluno da turma BR2E foram escolhidas de forma coerente as afirmações B e E. A justificativa da primeira etapa é coerente porque o aluno utiliza o tipo 2 de justificativa: "Por que quando a pessoa está trancada ela não vê o sol, ela só irá ver o sol quando ela sair daquele local.". Há, entretanto, uma incoerência com a justificativa da segunda etapa. Nela o aluno justifica sua escolha com base no tipo 1 "Por que não precisa identificar o filhote para que ele ser um filhote.". Deste modo, sua categorização é Conv\&Incoer.

Respostas divergentes e incoerentes (Div\&Incoer): são as respostas que divergem dos tipos de respostas e ainda possuem justificativas incoerentes com esses tipos. Como exemplo, um aluno da turma BR3E escolhe as alternativas A e E. A primeira justificativa afirma que "O Sol é uma coisa fantástica que acontece para todo mundo, pois o brilho do sol é a luz das pessoas.". Na segunda, o aluno justifica dizendo: "Pois a natureza é desse jeito, e so é proporcional para o animal e sua mãe.". Tanto a primeira quanto a segunda justificativa não possui coerência com os tipos 1 ou 2.

Questões incompletas ou preenchidas incorretamente foram separadas em uma categoria que não colabora efetivamente para as conclusões.

Vale observar que, na esperança de produzir um instrumento cuja intenção não fosse diretamente percebida pelo aluno, a segunda afirmação conta com três opções de escolha tornando assimétrica a disponibilidade para escolha entre as explicações do tipo 1 (duas opções) e as explicações do tipo 2 (três opções) disponíveis ao aluno. Essa assimetria pode levar à falsa sensação de que o instrumento seja tendencioso. Na verdade tal disposição não atrapalha a distribuição de respostas, pois elas são categorizadas aos pares e não independentemente. 
Assim se existem 2 opções para explicações do tipo 1 e outras 3 opções de explicações do tipo 2, então existem 3 combinações convergentes e outras 3 combinações divergentes conforme o quadro 8 abaixo.

\begin{tabular}{lll}
\hline Afirmação 1 & Afirmação 2 & Convergência \\
\hline Escolha tipo1 & Escolha tipo1 & \\
Escolha tipo2 & Escolha tipo2 & Convergente \\
Escolha tipo2 & Escolha tipo3 & \\
\hline Escolha tipo1 & Escolha tipo2 & Divergente \\
Escolha tipo1 & Escolha tipo3 & \\
\hline Escolha tipo2 & Escolha tipo1 & \\
\hline
\end{tabular}

Quadro 8: Possíveis combinações das escolhas para a análise em pares.

\subsubsection{Dimensão de alinhamento}

A Dimensão de alinhamento procura organizar os dados de modo a explicitar como a percepção dos alunos com relação a um acontecimento ou evento está alinhado com a percepção promovida pela sequência didática. Quatro categorias de análise foram idealizadas reagrupando de forma conveniente as respostas utilizadas da dimensão de continuidade.

Respostas que aderem à perspectiva da sequência didática: Essa categoria reúne respostas que se alinham com a perspectiva da sequência didática, ou seja, engloba as respostas que sugerem ser a ocorrência de fenômenos naturais independente de observadores. Nesta categoria são consideradas apenas as respostas convergentes e coerentes do tipo 1. Toma-se como hipótese de generalização ${ }^{20}$ que respostas associadas a esta categoria reflitam uma postura mais geral de seus autores tanto em relação à convergência quanto coerência nas justificativas dadas sobre outros fenômenos e situações futuras.

Respostas que não aderem à perspectiva da sequência didática: Essa categoria reúne as respostas que se apresentam contra a perspectiva da sequência didática. Ela contabiliza as respostas que sugerem que os fenômenos naturais fazem mais sentido quando suas explicações consideram a presença de observadores. De forma similar à anterior, são consideradas apenas as respostas convergentes e coerentes do tipo 2. A hipótese de generalização deste resultado é a 
expectativa de que o comportamento seja reprodutível para outros fenômenos e contextos de ensino parecidos, assim como na categoria anterior.

Respostas instáveis: Essa categoria representa as respostas de alunos que parecem não possuir estabilidade quanto a melhor forma de explicar os fenômenos naturais segundo os tipos de explicação. A categoria reúne as respostas que são divergentes, mas possuem coerência para explicações do tipo 1 e tipo 2 respectivamente. A hipótese de generalização considera que tais respostas refletem alunos que justificam coerentemente suas escolhas, mas que não utilizam uma única linha de raciocínio para um mesmo contexto.

Repostas dispersas: Essa categoria reúne todas as respostas incoerentes, ou seja, as que não pareceram capturar a essência esperada para a questão, pois pelo menos uma das justificativas não corrobora com as alternativas escolhidas na perspectiva da pesquisa. Utilizando-se da hipótese de generalização, essa categoria pode se tornar extremamente importante, pois apresentará uma noção da proporção de alunos que possuem percepção voltada para fora da estrutura do curso.

A categorização da dimensão de alinhamento está vinculada à análise da dimensão de continuidade. Essa característica faz com que a exposição de exemplos nesta seção dificulte a leitura da seção de análise. Deste modo, optou-se por transferir todos os exemplos e suas respectivas análises para lá. Caso o leitor deseje ver os exemplos, ele poderá saltar para a seção 5.1 Análise da pesquisa auxiliar página 109.

\subsection{PRINCÍPIOS DE DESIGN}

Nesta seção serão apresentadas as hipóteses, pressupostos e a base de desenvolvimento da sequência de RR. Sugere-se que a leitura desta seção seja feita com o volume II em mãos, pois há várias a figuras e textos referenciados a ele. 


\subsubsection{Protoprincípio de fluxo}

O desenvolvimento de uma sequência didática pode ser entendido como a busca da própria determinação para aqueles que se envolvem de alguma forma com ela. O reconhecimento da estrutura didática durante toda a criação e aplicação é uma demanda importante quando o processo de pesquisa é coletivo e se torna desafiador devido à gama de perspectivas diferentes e sobrepostas que definem a sequência. Por um lado, o pesquisador molda a sequência buscando rigor na produção e dados, por outro, o professor a molda para melhor se adaptar aos contextos escolares. $\mathrm{Na}$ posição central, encontra-se o aluno, que constrói conhecimento com elementos originais e elementos modulados pelas interpretações do professor e do pesquisador advindos das atividades trabalhadas.

A solução proposta neste trabalho foi a construção de uma estrutura didática baseada em fluxo a qual abrange tanto o processo de desenvolvimento nas instâncias do pesquisador e do professor quanto à coleta de dados na instância dos alunos. Entenda-se pelo termo estrutura baseada em fluxo didático a ideia de que uma sequência didática se organiza no espaço e no tempo didático. Isto é, as suas partes se interconectam didaticamente assim como a sua apresentação flui no tempo didático.

Com base na experiência e forma de trabalho praticados durante a pesquisa, é considerado que o desenvolvimento de uma sequência didática se inicia quando se configuram as primeiras narrativas didáticas. Estas expressam os desejos e criatividade dos desenvolvedores que trazem para a atmosfera do grupo o campo de ação, as abordagens, os conteúdos, as posturas e os objetivos encadeados com alguma lógica. Trata-se, portanto, do primeiro passo em direção à estabilização do que é ou será a sequência.

O engajamento na definição de algo coletivo, que idealmente pudesse ser reconhecido da mesma forma por todos, guia a discussão sobre as diversas narrativas didáticas e faz desenvolver a expectativa na existência de uma estrutura transversal a elas, unificadora. Entretanto, apenas com base nas narrativas didáticas, que são essencialmente idiossincráticas e, portanto ainda sofreram pouca interferência da coletividade, não é possível que algum dos sujeitos reconheça a unidade desta estrutura coletiva. Afinal, o que estaria por trás da união das narrativas didáticas? $\mathrm{O}$ que as conectaria? 
A grande variedade de interpretações e ênfases que o objeto em construção assume associado à intenção de materializá-lo justifica a adoção de procedimentos, padrões ou critérios reconhecidos por todos e destinados a guiarem o desenvolvimento. A primeira estrutura didática surge quando as narrativas didáticas são modificadas por seus proponentes de modo a convergirem para uma delimitação reconhecida por todos.

Objetivos, conteúdos e ordenação se organizam emancipando-se do controle individual e passam a determinar os elementos fundamentais que a sequência didática incorporará. A estrutura didática criada se transforma em pivô que guia as modificações subsequentes.

Em determinado momento, a sequência didática é considerada suficiente para aplicação. As interpretações do professor são postas em prática na sala de aula e o retorno da classe permite a comparação entre a estrutura didática que gostaríamos de apresentar e a estrutura didática efetivamente vista na perspectiva dos alunos.

O cenário de desenvolvimento apresentado acima associado à busca por pontos de apoio que guiassem a produção favorece a continuidade da pesquisa em DBR assim como sugerida por Collins, Joseph e Bielaczyc (2004) e Lijnse, P., (2004). Isso leva a dois pontos fundamentais na pesquisa: o primeiro é a forma como foi feita a convergência das perspectivas dos desenvolvedores para a criação da estrutura; o segundo é a forma como foi considerada a convergência das perspectivas que os alunos tiveram quando a estrutura didática esteve em ação.

Para o gerenciamento dos trabalhos de criação coletiva, onde tanto o conteúdo quanto a forma de trabalho não estavam bem determinados, utilizou-se como base uma forma semelhante à proposta por Brockington (2005), na qual ele define:

"(...) como "marcadores" principais aqueles saberes cruciais para estabelecer as ligações entre os elementos constituintes da nova estrutura que criávamos. (...) Assim, estes "marcadores" atuaram como pontos de intersecção da nova estrutura gerada, permitindo, por exemplo, refazer os trajetos que unem os conceitos, bem como fornecer indícios sobre outros caminhos. Desta forma, todos os novos conceitos inseridos na estrutura do novo saber, bem como as atividades, devem sempre se adequar a estes marcadores, aumentando as chances de sobrevivência no ambiente escolar." (BROCKINGTON, 2005) 
Tais marcadores incluem um caráter "entrópico" ao processo de desenvolvimento, ou seja, permite que decisões coletivas caminhem em uma direção sem que haja grandes retornos ou restruturações de temas já tratados. Naquela pesquisa, o critério utilizado foi relacionado às regras da transposição didática de Chevallard (1991) na busca por uma estrutura com características que favorecessem a sobrevivência dos saberes escolhidos no ambiente escolar.

No desenvolvimento da sequência didática sobre $R R$, o movimento de adequação das novas ideias foi parecido aos presentes nas discussões feitas no trabalho de Brockington (2005). Entretanto os critérios adotados foram associados à fluência que se esperaria do conjunto sequenciado e os objetivos que cada atividade ia adquirindo ao longo do desenvolvimento. Os objetivos, por sua vez, foram desenvolvidos tendo por pano de fundo os obstáculos didático pedagógicos, epistemológicos e nos detalhes críticos, os quais serão discutidos mais adiante.

O fluxo pretende indicar quais são os elementos fundamentais da sequência didática e como deveriam ser encadeados promovendo um tipo de estrutura didática representado pelo diagrama de fluxo. Esse seria avaliado por meio de um instrumento de análise qualitativa denominado instrumento de fluxo. Durante a pesquisa, essa ideia surgiu simultaneamente às primeiras atividades como uma mistura de objetivos conceituais e objetivos didáticos. Rapidamente o fluxo se destacou da sequência se tornando um guia para a determinação do encadeamento das atividades.

Defende-se aqui que o desenvolvimento baseado em fluxo permita a criação de uma estrutura didática coesa e coerente. A coesão se daria no sentido de possuir transições sem quebras entre atividades, que não fragmentassem os objetivos centrais em um mosaico de informações. A coerência ${ }^{21}$ estaria associada ao mantenimento de uma lógica perceptível aos integrantes da interação didática. $\mathrm{O}$ fluxo seria totalmente dependente da intenção didática responsável pela fluência das atividades. Seria também caracterizado por transcender as atividades tomadas na individualidade. Ele refletiria a pretensão idealizada por seus criadores incorporando informações sobre a maneira como cada uma destas atividades se relaciona com as atividades anterior e posterior.

Não se espera que o fluxo seja usado da mesma forma por todas as pessoas envolvidas com a sequência. De forma prática, trata-se de um guia flexível 
para os desenvolvedores em processo de criação os quais procuram integrar fluentemente as atividades em uma estrutura cuja a coerência e coesão seja pautada por uma determinada intenção didática. Para os professores no momento da aplicação, ele acaba sendo algo mais rígido, pois durante as aplicações, a coerência é majoritariamente deixada a cargo da estrutura didática e o professor direciona maior atenção para a coesão da sequência. Para o aluno, seria algo transparente, mas percebido por meio da fluência das atividades.

Utilizando uma analogia geométrica com auxílio da figura 6 , pode-se dizer que a sequência didática é a área total vinda da soma dos significados individuais de todos os que se envolvem de algum modo com ela. Cada um atribui um significado,

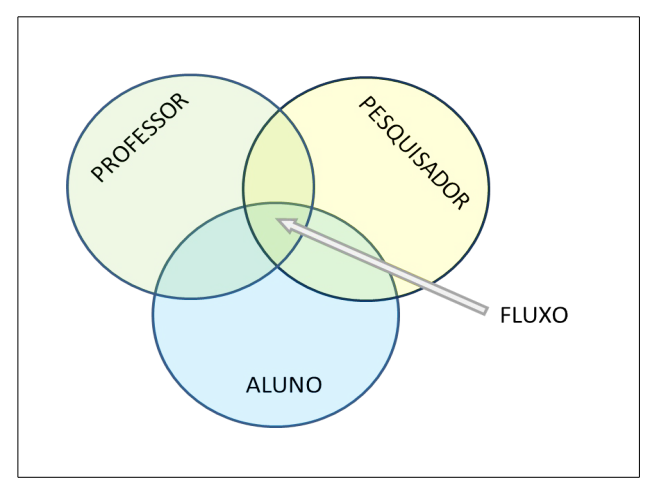

Figura 6 - metáfora geométrica do significado de fluxo com os sujeitos agrupados por instâncias.

forma de trabalho ou percepção individual que se sobrepõe aos dos demais. A produção da sequência utilizando o protoprincípio de fluxo pretende fazer existir uma pequena região de interseção na qual o conjunto de significados dos participantes estejam mais ou menos alinhados. Com base nesta interseção se espera que o grupo concorde ou encontre elementos que permitam a construção do diagrama de fluxo da sequência. Essa representação, dinâmica ao longo do desenvolvimento, é a materialização da intenção didática presente na sequenciação das atividades. $O$ diagrama corresponde à espinha dorsal que identifica a sequência para o próximo ciclo de pesquisas.

Todas essas ideias definem a essência e a intenção do protoprincípio de fluxo, mas é indispensável que exista uma dimensão prática associada a ele para a consecução da pesquisa. Por isso, toda discussão sobre a organização das atividades é feita a partir do diagrama de fluxo (figuras 7, 8 e 9, páginas 77, 78 e 79). 


\title{
4.3.2 Detalhes Críticos
}

A noção de detalhes críticos (VIENNOT, 2004) foi utilizada durante as discussões para o desenvolvimento do material. Detalhes críticos são aspectos didáticos negativos que aparentam ter pouca importância no planejamento e aplicação de aulas ou sequências didática, mas que revelam ter grande importância ao final do processo de ensino-aprendizagem. As pesquisas nesta direção investigam estes aspectos de forma precisa relacionando as intenções didáticas dos professores durante o preparo das aulas e as efetivas ações que adotam em classe.

Viennot $(2001,2004)$ apresenta uma série de exemplos deste tipo de detalhe. Em falas inadequadas onde as leis de Newton são utilizadas. Um detalhe verbal presente na afirmação de que um determinado objeto "tenha uma força" em vez de "exercer uma força" dificulta a compreensão sobre como os objetos interagem e onde as forças são aplicadas.

\begin{abstract}
"Frequentemente é dito que o peso de um objeto "age sobre seu suporte", ou que a força centrífuga "de" uma bola em movimento circular na ponta de uma mola é vista como agindo na própria bola (no referencial da sala). Mas podem ser confundidos, devido o significado do "de", o objeto que exerce força com o objeto no qual a força é aplicada. Esta expressão inadequada coincide com um estilo antropomórfico e pode contribuir para turvar a distinção que deveria ser feita entre a segunda e terceira leis de Newton." (VIENNOT, $2001)^{22}$
\end{abstract}

Outro detalhe crítico apresentado por Viennot (2001) se refere à situação em que dois objetos estão em contato. É comum observar professores solicitando aos alunos a compreensão das forças presentes "no ponto de contato". Nesse esforço, o "ponto" passa a receber status de objeto o que leva o aluno erroneamente a aplicar a segunda lei de Newton nele. Ou ainda, a expressão "a força de A sobre B" ao invés de "a força exercida por A sobre B" é um detalhe que gera um forte ruído no percurso para a compreensão do conteúdo conceitual.

22 Tradução nossa. "Often, the weight of an object is said to "act (as well) on its support", or the centrifugal force "of" a ball in circular motion at the end of a string is seen as acting on the ball itself (in the frame of reference of the room). But there is a risk of confusing, under the shelter of this "of", the object that exerts the force with the object on which it is applied. This improper expression coincides with an anthropomorphic style, and might contribute to blurring the distinction that should be done between Newton's second and third law." (VIENNOT, 2001) 
Associado à experimentação, ela apresenta o exemplo de uma sequência didática dedicada ao estudo de cores em que se pretendia mostrar como a luz azul é absorvida por um objeto vermelho (à luz branca). O resultado esperado pela classe era a visualização de um objeto preto tendo em vista a expectativa de que o objeto vermelho absorvesse a radiação azul. Na prática, os alunos acabaram por ver um objeto violeta devido ao largo espectro emitido pela lâmpada, esse fato permitiu uma conexão errada entre os conhecimentos produzidos naquele momento como os produzidos anteriormente sobre mistura de pigmentos (vermelho e azuis resultavam em violeta).

Estes e outros exemplos trazem informações que contribuem especificamente para o tratamento de certos conteúdos conceituais. Nesta pesquisa utilizamos as ideias de detalhes críticos relacionados à semântica de algumas palavras chave utilizadas com, por exemplo, "diferenciação do tempo" ou "evento". Ideias sobre a representação da luz e a possível interpretação materializadora do feixe por parte dos alunos também foi considerada especialmente no tratamento do relógio de luz. A forma como isso foi tratado pode ser vista na seção 4.3.4 Princípios de design aplicados na sequência didática e diretamente no material do professor de cada atividade no volume II.

É razoável esperar adesão a novas perspectivas de trabalhos e metodologias numa equipe composta por professores e pesquisadores empenhados na construção e aplicação de uma sequência didática. Entretanto, umas das dificuldades em se utilizar os conhecimentos sobre detalhes críticos na prática está no fato de que, mesmo nessa situação, há grande resistência em adotar uma mudança de postura com relação eles. Isso ocorre porque os detalhes criticos estão escondidos em hábitos adquiridos de trabalhos anteriores, jargões aprendidos ou desenvolvidos dentro do próprio período de pesquisa ou tais detalhes simplesmente estão longe dos objetivos mais complexos das atividades. Eles acabam sendo esquecidos com facilidade nos momentos das interações. Sobre isso Viennot (2001) afirma que

"Outra boa razão para seguir em frente com otimismo é que quando sequências baseadas em pesquisa associam estratégias desenhadas cuidadosamente com objetivos precisos de ensino, grande atenção é dada aos (muitos) aparentemente pequenos aspectos, o sucesso é 
impressionantemente estável, mesmo se limitado." (VIENNOT, $2001)^{23}$

Nesse sentido, a metodologia DBR pode ser frutífera pois, assim como a noção de detalhes críticos, possui um compromisso com a relação entre as especificidades do conteúdo conceitual e a prática docente relacionada. Essa combinação permitiu aproximar os detalhes críticos dos objetivos centrais de cada atividade ou, ao menos, incluí-los como parte integrante das sugestões de aplicação.

\subsubsection{Obstáculos epistemológicos e didático-pedagógicos}

A ideia de objetivo-obstáculo é um dos princípios utilizados para a produção das atividades da sequência didática.

Astolfi (1994) apresenta o obstáculo como uma estrutura de pensamento não desejada e responsável pela emergência de um mesmo padrão nas diversas concepções alternativas que os alunos apresentam. Desta forma, um obstáculo seria algo mais profundo do que uma representação alternativa, ele estaria apoiado por uma rede de ideias sobre a qual o aluno interpreta, segundo sua própria lógica, os mecanismos que regem o mundo a sua volta.

Como exemplo de obstáculo, Astolfi (1994) apresenta o raciocínio linear causal proposto por Viennot, em Bednarz y Garnier (1989). Nele, a explicação sobre uma onda eletromagnética feita por alunos que enfrentam esse obstáculo consideraria relações entre campo elétrico e campo magnético como uma sequência cronológica em que inicialmente um dos campos variaria para depois o outro campo ser criado. Uma onda eletromagnética apresenta factualmente tais fenômenos de forma simultânea. O mesmo ocorre quando se procura conhecer como os alunos visualizam uma determinada cadeia alimentar num estudo ecológico. Normalmente ela é compreendida a partir situações sequenciais: primeiro os produtores na base da cadeia são alimento para os consumidores, depois, os consumidores são alimento para os decompositores e assim por diante. Essa visualização sequencial contrasta com a dinâmica simultânea que efetivamente ocorre na natureza e se

23 Tradução nossa, "Another good reason to go on with optimism is that, when research-based sequences associate carefully designed strategies with precise teachings goals, a great attention being given to (many) apparently small aspects, the success is impressively stable, even if limited." (VIENNOT, 2001). 
pretende ensinar. Esses dois exemplos distintos de concepções alternativas se apoiam no mesmo obstáculo o qual compreende que relações lógicas de um sistema podem ser tomadas como cronológicas.

Uma vez conhecido o obstáculo que se pretende atacar em sala de aula, três passos são sugeridos para superá-lo. Inicialmente é necessário conscientizar os alunos do seu próprio modelo e a forma como seu intelecto o utiliza. Posteriormente se produz condições para se discutir e opor pontos de vista. Finalmente, para se superar o obstáculo, um modelo explicativo alternativo ao do aluno, que seja mentalmente satisfatório deve estar presente no processo didático. Esse último passo é lento, pois o aluno deverá construir novas ferramentas e depois fazê-las funcionar em novos contextos. Somente assim o aluno poderá dispor delas confortavelmente.

Astolfi (1994) indica como utilizar o obstáculo de forma prática em três vertentes. A ideia de obstáculo pode ser aplicada como uma ferramenta para regular as intervenções didáticas de modo que os obstáculos seriam referências para os professores que possuíssem suas sequências centradas em outros objetivos. Como referência para a construção curricular, podendo ser utilizado como sinalizador do avanço intelectual de cada etapa indicando as diferenças entre as abordagem anterior e posterior no caso de um currículo espiral. Ele também pode ser utilizado como modo de seleção do objetivo de uma sequência quando colocado como o objetivo em uma atividade ou sequência didática.

Nesse último caso, o obstáculo é promovido a objetivo-obstáculo e posicionado centralmente na sequência didática. Os conhecimentos sobre o obstáculo e a intenção didática de superá-lo são os pontos de partida para o desenvolvimento das atividades de uma sequência. Essa perspectiva foi utilizada no trabalho.

Durante o desenvolvimento específico de cada atividade, a noção de objetivo-obstáculo foi utilizada de forma expandida, considerando-se não só os aspectos epistemológicos do conhecimento produzido em classe, mas também os aspectos didático-pedagógicos relacionados com a atuação do professor. Segundo Pietrocola (2008), o desenvolvimento e direcionamento de sequências didáticas de FMC enfrentam obstáculos típicos presentes na atualização/modernização dos conteúdos de física na escola. Em seus estudos, os dois grandes grupos de obstáculos, epistemológicos e didático-pedagógicos, têm origem de adaptações 
sobre as obras de Bachelard (1938) e de Brousseau (1986) ${ }^{24}$.

A perspectiva de obstáculos epistemológicos é baseada naqueles apresentados originalmente por Bachelard (1938), são definidos como obstáculos para o desenvolvimento conhecimento científico. Entretanto, como a epistemologia é tratada não nos domínios científicos, mas sim nos domínios escolares, considera-se a ideia dos obstáculos epistemológicos de modo ampliado e adaptado ao contexto do ensino de modo a serem divididos em 4 categorias:

1. Fenomenologia - obstáculo relacionado às dificuldades em explorar os fenômenos de física moderna e contemporânea por meio de experimentos simples em classe. Para o caso da RR poderia ser posta a seguinte linha de questionamento: se a soma de velocidades poderia ser facilmente apresentada a partir de vídeos gravados em diferentes referenciais, como a constância da velocidade da luz poderia ser visualizada?;

2. Linguagem/formalização - relaciona-se à dificuldade em encontrar transposições didáticas que formalmente simplifiquem a linguagem matemática relacionada a conteúdos de física moderna e contemporânea. Diferentemente de abordagens clássicas que já por décadas possuem formalização matemática transposta e reconhecida na esfera do saber a ensinar, ainda não existem caminhos simples em física moderna e contemporânea, pois os conceitos são acessados majoritariamente por meio de transformações lineares, tensores, gradientes, etc;

3. Estruturação conceitual - relaciona-se à não existência de um caminho analógico para a construção de certos conceitos com base na vivência ou conhecimentos clássicos anteriores. Como criar uma analogia ao comportamento absoluto e clássico do tempo para a ideia relativística de que a duração entre dois acontecimentos dependam do referencial do observador?

4. Ontologia de base - está associado à relação que muitos conceitos modernos possuem com a intuição. Compreender a característica de não simultaneidade do tempo, por exemplo, é totalmente contra intuitivo quando o tempo é utilizado normalmente no dia a dia para conversação em telefones celulares ou mesmo na sincronização de compromissos.

Os obstáculos didático-pedagógicos, por sua vez, são as dificuldades que 
provavelmente serão enfrentadas pelos professores que irão desenvolver trabalhos de física moderna em suas turmas. Pietrocola (2008) os divide em cinco categorias para se enquadrarem no contexto da Física Moderna:

1. Hierarquia conceitual de pré-requisitos - Surge da associação entre história do desenvolvimento da Física e complexidade dos conteúdos. O obstáculo é gerado pela hipótese de que conceitos "menos complexos", que surgiram primeiro na história da física, devem vir antes dos "mais complexos", os quais são associados aos conceitos modernos. Esse obstáculo didáticopedagógico leva o professor a acreditar na necessidade de ensinar física clássica antes de tratar de ideias modernas e contemporâneas com os alunos;

2. Didática intuitiva dos professores - Aparece quando é necessário discutir a tradição que define como ensinar e o que é física. A utilização de textos em classe, por exemplo, não raramente é recebida com preconceito pelos professores que se deparam com este obstáculo;

3. Seleção de conteúdos - Relacionado à quebra dos currículos escolares sedimentados historicamente pelo uso e pela necessidade de assumir riscos com a nova abordagem. Trata-se da dificuldade em suprimir um conteúdo tradicional e estabilizado em virtude de outro inovador, tido como não confiável;

4. Tipos de atividades propostas - Obstáculo associado à incompatibilidade das metodologias de ensino tradicionais na abordagem de conteúdos modernos e contemporâneos. Muitas vezes metodologias tradicionais tidas pelos professores como boas para o ensino de determinado conteúdo, tais como a resolução de problemas fechados ou exposições na lousa, passam a constituir um obstáculo quando são necessárias abordagens alternativas como discussões coletivas ou mesmo jogos didáticos para a compreensão de determinado aspecto de FMC;

5. Avaliação - Assemelha-se aos obstáculos de seleção de conteúdo, mas estão relacionados às formas de avaliação empregadas e seus valores. Neste caso, há resistência à adoção de avaliações com critérios de maior subjetividade, por exemplo.

Tanto os objetivos-obstáculos quanto os detalhes críticos nortearam a 
produção da sequencia didática. Na seção seguinte será possível verificar como cada um destes elementos participaram da produção das atividades.

\subsubsection{Princípios de design aplicados na sequência didática}

Nesta seção serão apresentados como os princípios de design foram aplicados durante a construção da sequência didática. Os princípios de design são o grupo de ideias teóricas mais influente na estruturação da sequência. Entretanto, várias ideias pontuais de menor impacto geral foram adotadas posteriormente a alguma discussão ou aplicação constituindo, quando tomadas em grupo, um papel importante na identidade da sequência. Deste modo, é importante considerar o próprio material da sequência (anexo 3, volume II), em especial o dedicado aos professores, como parte integrante da descrição da intenção didática pretendida.

Existe uma tênue e abrangente lição que permeia toda a sequência. Ela está relacionada ao que parece ser absoluto no universo: a crença de que o tempo físico é imutável sob qualquer perspectiva. A sequência didática se propõe abordar essa crença trazendo, em etapas, elementos que ponham em xeque esta afirmação. $O$ tempo clássico, tido como grande "sincronizador" de tudo que acontece foi questionado com vistas no paradigma relativístico. Isto é, será tratado como fruto de uma percepção limitada do homem sobre a natureza, pois o tempo relativístico depende da forma como é observado. Mas o que fazer sobre isso? Como se situar temporalmente no universo? Quando é que as coisas efetivamente ocorrem se o período de tempo entre o nascer e o morrer pode ser diferente dependendo de como isso seja observado? Para responder a essas questões, é proposta a adoção de um novo conceito absoluto constituído por uma imbricada relação entre espaço e tempo e matematicamente representado pelo conceito de intervalo relativístico. Essa nova visão de mundo torna necessária a compreensão do universo onde a "duração" passa a ter relação com a velocidade relativa.

Compreender essa ideia que abrange transversalmente toda a sequência exige um farol direcionador das múltiplas dimensões da intenção didática. Portanto, tomou-se o objetivo-obstáculo relacionado ao absolutismo do tempo como central da sequência. Ele está relacionado à tendência natural de se considerar o conceito de tempo newtoniano como obviamente absoluto. Como sua abrangência permeia 
todas as atividades, sua descrição deve ser objetiva para ser aplicável. Abaixo, é possível observar suas características.

Obstáculo: o tempo é absoluto

Conceito pretendido: o tempo é relativo

O que o obstáculo impede de compreender: a diferenciação do tempo; o paradoxo dos gêmeos; a relação entre tempo e velocidade relativa; o tempo como uma componente espaço-temporal.

A rede de ideias associadas que explicam a resistência do obstáculo: a noção de tempo é óbvia; o tempo é universal e sincroniza tudo o que acontece no mundo; todos os relógios são sincronizados; ninguém tem dúvida de que o tempo é igual para todos; não há situação cotidiana em que o tempo se diferencie;

As condições de possibilidade de superação do obstáculo: o tempo de vida médio das partículas dependem da velocidade relativa; a aplicação lógica da constância da velocidade da luz prova que o tempo não é absoluto; é possível verificar macroscopicamente o não absolutismo do tempo.

\subsubsection{Representação gráfica do Fluxo}

A representação do fluxo precisa necessariamente ser simples para que seja eficiente durante o desenvolvimento da sequência. O diagrama de fluxo simplifica e materializa a intenção didática pretendida usando basicamente três tipos de objetos.

O primeiro é a "moral da história" didática que cada atividade deve garantir. Trata-se de uma afirmação que condensa e permite a visualização da mensagem central da atividade. Ela tem grande importância pois define as questões que serão empregadas no instrumento de coleta de dados. Sua representação está na forma de retângulos.

A conexão entre as atividades é feita no diagrama por meio de conectores hexagonais. Os conectores ligam a "moral da história" de cada atividade utilizando uma questão simples. Essa questão representa a dúvida que deveria se colocada na atividade para fazer a conexão com a atividade subsequente para criar a fluência esperada.

Os círculos cinzas dispostos lateralmente são os circuitos sugeridos para 
que as aulas convirjam para o fluxo proposto. Na prática são os principais momentos de cada atividade e refletem mais ou menos a pretensão cronológica do material desenvolvido para a respectiva atividade. Nas figuras abaixo, é possível observar o diagrama de fluxo final associado à sequência do Paradoxo dos Gêmeos. 


\section{TLS - Paradoxo dos gêmeos: Diagrama de Fluxo}

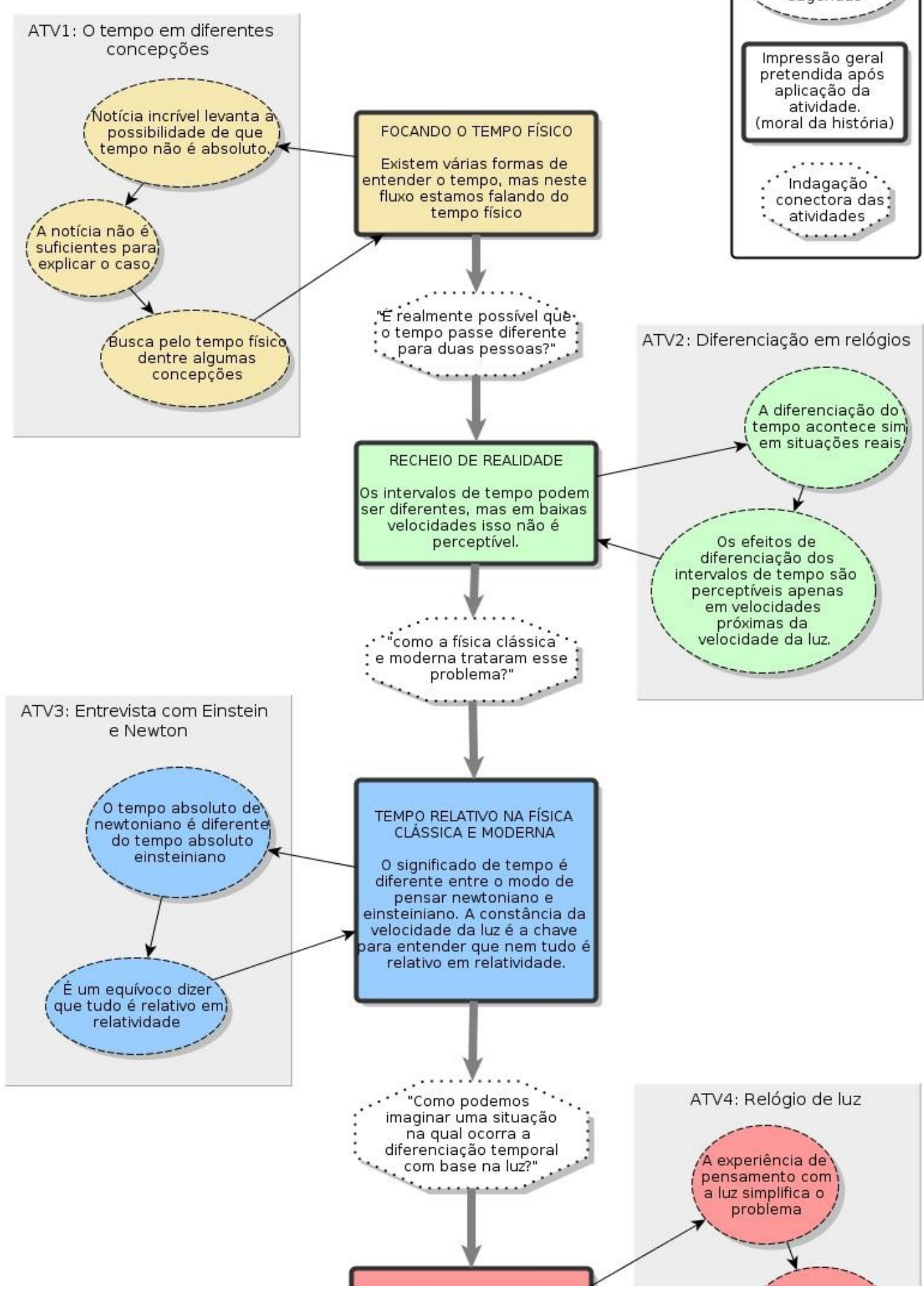

Figura 7 - Diagrama de fluxo da sequência didática (Parte 1 de 3) 


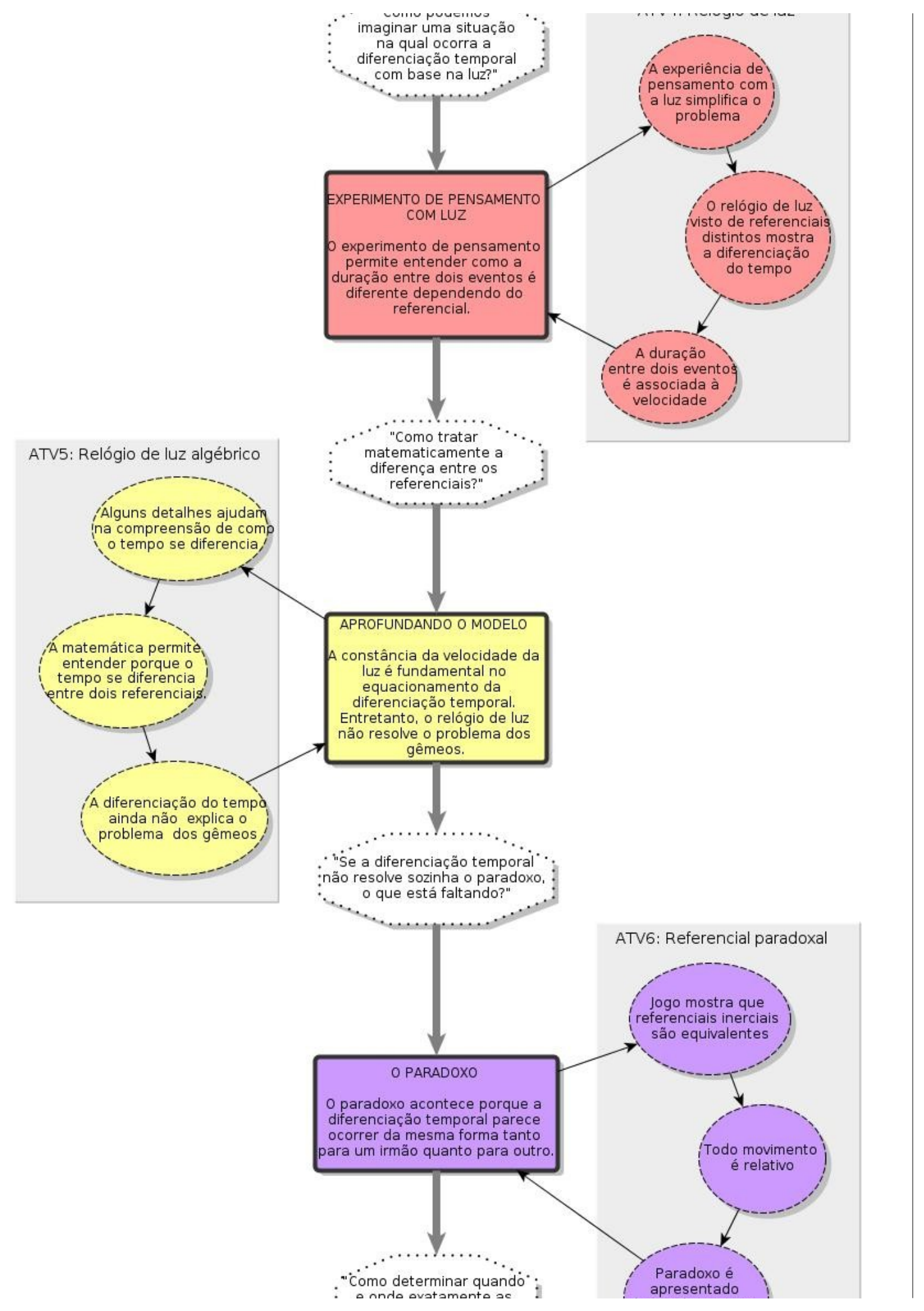

Figura 8 - Diagrama de fluxo da sequência didática (Parte 2 de 3) 


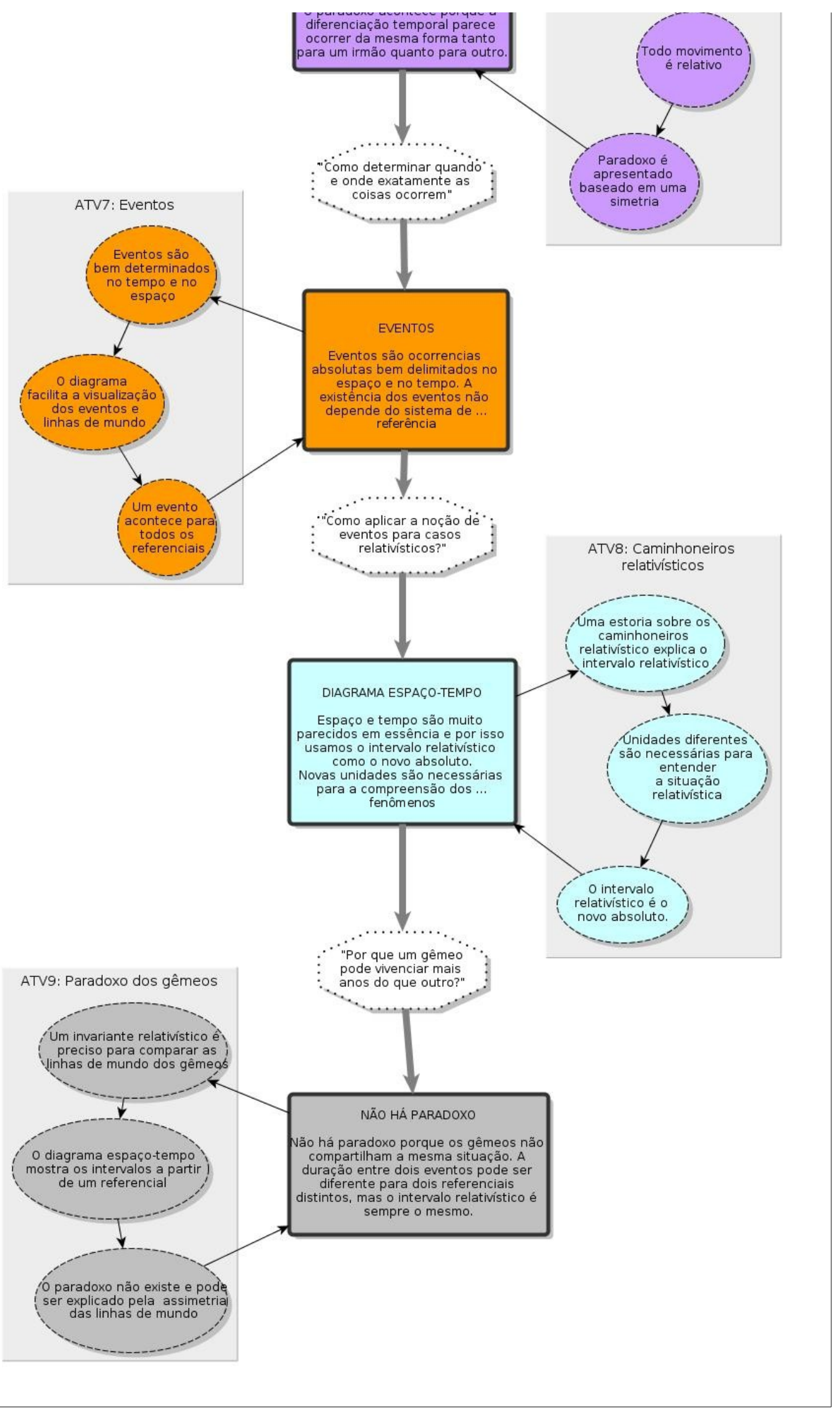

Figura 9 - Diagrama de fluxo da sequência didática (Parte 3 de 3) 
No quadro 9 é possível observar as atividades e estimativa de tempo baseada nas aplicações efetuadas. No total são aproximadamente 12 aulas de 50 minutos conforme o quadro abaixo.

\begin{tabular}{cll}
\hline Atividade & \multicolumn{1}{c}{ Nome } & \multicolumn{1}{c}{ Tempo médio gasto } \\
\hline 1 & O tempo em diferentes concepções & Aproximadamente 1 aula \\
2 & Diferenciação em relógios & Entre 1 aula e 1,5 aulas \\
3 & Entrevista com Einstein e Newton & Entre 1 aula e 1,5 aulas \\
4 & Relógio de luz e solicitação de trabalho extraclasse & Entre 1 aula e 2 aulas \\
& para a atividade 6 & \\
5 & Relógio de luz algébrico & Entre 1 aula e 1,5 aulas \\
6 & Referencial paradoxal & Aproximadamente 1 aula \\
7 & Eventos & Aproximadamente 2 aulas \\
8 & Caminhoneiros relativísticos & Aproximadamente 1 aula \\
9 & Viagem no espaço-tempo & Entre 1 aula e 1,5 aulas \\
\hline
\end{tabular}

Quadro 9: Atividades e estimativa de tempo da sequência didática

\subsubsection{Atividade 1 - O tempo em diferentes concepções}

A primeira atividade pretende criar contraste entre o conceito de tempo físico e as demais concepções de tempo que normalmente surgem durante estudos que envolvam Relatividade.

A experiência do grupo em propostas anteriores mostra que os alunos não possuem clara distinção entre as diferentes concepções de tempo que eles mesmos possuem. A existência desta dificuldade é corroborada pelos estudos feitos por Ferrer (2004). Por outro lado, a abordagem deste problema exige metodologias e posturas que o professor normalmente não possui.

Desta forma, a dificuldade na estabilização do tempo físico como objeto de estudo se constitui a primeira etapa para atacar o objetivo-obstáculo do tempo absoluto. A solução encontrada pelo grupo consistiu em uma atividade introdutória que levantasse e discutisse concepções de tempo e distinguisse o tempo físico como objeto de estudo. Com relação ao fluxo, o material problematiza a situação onde irmãos gêmeos possuem idades diferentes e coloca dúvidas sobre o absolutismo do tempo físico. Para criar fluência e expectativa para a atividade seguinte a questão explícita ou implícita na aula é sugerida: é realmente possível que o tempo passe diferentemente para duas pessoas? 


\subsubsection{Atividade 2 - Diferenciação em Relógios}

A segunda atividade aborda a ordem de grandeza e a relação existente entre a velocidade e a diferenciação temporal mostrando o porquê de não podermos perceber tais fenômenos no cotidiano. A abordagem deste aspecto fenomenológico é complementar à atividade anterior, pois carrega consigo a intenção de trazer sentido de realidade ao fenômeno relativístico separando ficção da realidade para que o aluno reconheça a diferenciação temporal e suas causas. Foca-se no obstáculo epistemológico relacionado às dificuldades fenomenológicas promovendose discussões e solucionando problemas baseados numa reportagem real que relata o uso de relógios atômicos para demonstrar a teoria da Relatividade de Einstein.

A matemática necessária para estruturar os conceitos pretende surgir gradualmente durante a sequência. Questões envolvendo porcentagem apresentam a ordem de grandeza em que a diferenciação temporal ocorreria caso a reportagem dos gêmeos fosse verdadeira criando conexão com a atividade anterior. A relação entre velocidade e diferenciação é apresentada qualitativamente para garantir alguma explicação ou causalidade ao fenômeno. Sua abordagem é feita em maiores detalhes na atividade 4 e 5 .

Um dos detalhes críticos considerados importantes na construção da sequência está relacionado às palavras comumente utilizada em Relatividade. Não é incomum encontrar, na esfera do saber a ensinar, a apresentação e construção de conceitos relativísticos por meio de aproximações analógicas baseada em palavras emprestadas da física clássica ou de outros contextos.

Neste sentido, o termo largamente utilizado "dilatação do tempo" deve ser atacado. Esse termo se refere à diferenciação que a duração entre dois eventos apresenta quando tais eventos são observados a partir de referenciais distintos. Em outras palavras, se à meia noite, o leitor segura um grande relógio pendurado em sua mão e aguarda 15 minutos para que o ponteiro grande aponte para o "3", um viajante em velocidade relativística observando a mesma situação afirma, com base no próprio relógio de pulso, que demorou mais do que apenas 15 minutos para que o ponteiro do relógio grande do leitor estivesse sobre o mesmo "3", talvez ele afirme ter demorado uma hora. Desta forma, diz-se que o tempo para que o ponteiro se desloque de "12" para " 3 " está dilatado para o viajante.

Mesmo que o exemplo acima seja considerado claro, trabalha-se com a 
hipótese de que o termo "dilatação temporal" ainda pode gerar dificuldades a quem tente compreendê-lo. Dilatar significa aumentar de tamanho, expandir e, em último caso, prolongar no tempo. Então, como pensar o tempo dilatando? O tempo expande para onde?

De fato, o termo "dilatar" se relaciona bem com o campo semântico em torno do conceito relativístico de espaço-tempo, pois nesse caso as distorções em quatro dimensões são melhor representadas por uma visualização espacializada. Aparentemente, as palavras historicamente empregadas para se relacionar com o conhecimento clássico de relatividade migraram e se modificaram para se adequarem à relatividade einsteiniana. Assim, a componente temporal relativística acabou se utilizando da palavra "tempo" vinda do conceito clássico, mas a palavra "tempo" nesse caso não é clássica e se refere ao elemento de medida que compõe o espaço-tempo, carrega consigo características espaciais como a capacidade de dilatar.

Essa analogia e construção semântica é natural no desenvolvimento do saber sábio já que não há palavras para expressar aquilo que é novo. Entretanto, esse movimento deve ser inverso na esfera do saber ensinado que está construindo o universo relativístico em classe. $\mathrm{O}$ aluno ao ler ou escutar as palavras que irão se vincular aos conceitos elementares trazidos na aula, não possui clareza sobre a origem de formação destas palavras acreditando serem autoexplicativas. Assim, o mosaico semântico "dilatação temporal" pode ser considerado literalmente pelo aluno se constituindo num detalhe crítico.

Desta forma, o termo "dilatação temporal" foi substituído nas atividades por "diferenciação temporal". Adota-se a hipótese de que este último termo torna mais claro o que ocorre quando se compara o tempo em um com o tempo em outro referencial.

\subsubsection{Atividade 3 - Entrevista com Einstein e Newton}

A terceira atividade termina a parte introdutória da sequência e fomenta uma discussão contrapondo as diferenças entre o tempo para Newton e o tempo para Einstein. O objetivo da atividade é explicitar suas diferenças indicando que não se trata de um rompimento apenas com o senso comum, mas sobretudo uma ruptura 
na forma como a Ciência conceitua o tempo.

De forma secundária, a constância da velocidade da luz é introduzida como princípio que justifica o comportamento temporal relativístico. Pretende-se atacar a famosa frase "tudo é relativo" apresentando o caráter absoluto da luz sem grandes detalhes.

A busca da expansão conceitual sobre tempo implica na articulação do conceito de tempo relativístico com base num modelo que dê conta de representar o universo de forma coerente. Entretanto, o conceito de tempo absoluto é basal na interpretação do mundo e a construção do esperado modelo demanda estudos que até então não foram desenvolvidos pelo aluno. Com experiência anteriormente adquirida pelo grupo, pode-se afirmar que é relativamente comum que o aluno aplique a noção de tempo relativístico dentro do modelo clássico proliferando uma série de incompatibilidades lógicas no início de seus estudos. As situações considerada mais simples como a sincronicidade dos acontecimentos e a possibilidade do tempo passar de forma diferente para pessoas diferentes se tornam difíceis de aceitar e por vezes são repelidas fortemente devido ao obstáculo relacionado à ontologia de base da diferenciação do tempo. Nesse sentido, acreditase que a abordagem epistemológica tranquilize o aluno por mostrar que tais discordâncias não são exclusivamente deles, mas também permeiam as discussões científicas e preocuparam autoridades reconhecidamente importantes como Newton e Einstein.

A atividade apresenta uma entrevista fictícia onde Newton e Einstein falam sobre suas concepções sobre relatividade. O texto não pretende ser histórico, mas preserva a essência dos pensamentos na tentativa de mostrar que a representação do universo depende dos princípios adotados. No caso de Newton, o princípio de um tempo absoluto e intangível é suficiente para conceituar o tempo clássico, para Einstein, a constância da velocidade da luz é a chave para a construção do conceito de tempo relativístico. A conexão com a atividade posterior surge da dúvida sobre como efetivamente construir uma situação onde seja possível estudar quantitativamente a diferenciação temporal. 


\subsubsection{Atividade 4-R-Luz}

A atividade 4 trata da construção de um experimento de pensamento, denominado relógio de luz, cujo foco de articulação conceitual gira em torno da constância da velocidade da luz. A construção do experimento de pensamento é apresentada ao aluno a partir de três elementos principais.

O primeiro deles é a característica da luz em manter-se sempre com o mesmo módulo da velocidade para qualquer referencial. Sobre isso, vale observar que esse assunto foi discutido durante a produção da sequência sob a forma de obstáculo didático-pedagógico de hierarquia conceitual, pois os professores recorrentemente consideraram os conhecimentos sobre referenciais e soma de velocidades como pré-requisito à compreensão do experimento do relógio de luz aparentemente embasados em experiência no ensino de cinemática.

O conceito de referenciais era necessário, mas o fluxo, ainda em desenvolvimento naquele momento, indicara que a abordagem tradicional destes assuntos geraria uma série de problemas. Por um lado, abordar a noção de referenciais utilizando conhecimentos sobre soma de velocidades implicaria na produção de atividades compostas por conceito relacionados ao espaço, o qual possui uma série de obstáculos epistemológicos próprios demandando uma quantidade excessiva de aulas. Por outro, os conhecimentos em discussão eram os advindos da física clássica e não se relacionavam diretamente com a situação relativística. A abordagem relativística da soma de velocidades seria impraticável devido à complexidade do assunto.

A solução, pautada pela busca de um fluxo mais objetivo e sem digressões, resultou numa transposição que abandona o conteúdo relacionado à soma de velocidades relativísticas, mas apresenta o conceito de referenciais pouco a pouco ao longo das atividades $4,5,6$ e 7 .

Um dos objetivos é incorporar ao modelo que está sendo construído uma visualização guiada pelo primeiro postulado relativístico, mas com recursos matemáticos simplificados. Deste modo, apenas a visualização do experimento de pensamento a partir de dois referenciais é trabalhada durante a atividade 4 . Secundariamente, pretendeu-se atacar a confusão semântica em torno do termo "velocidade constante" que para o aluno, pode significar erroneamente que a luz possui velocidade constante em qualquer meio em vez por mudança de referencial. 
O segundo elemento que compõe a atividade é a compreensão do funcionamento do experimento de pensamento. Este consiste na observação do relógio de luz a partir de dois referenciais considerando a velocidade da luz constante. O relógio de luz é um instrumento de pensamento largamente utilizado em livros para a explicação de fenômenos como a diferenciação do tempo e a contração do espaço. Ele é composto por dois espelhos paralelos perfeitos que refletem continuamente um fóton. O tempo de cada ciclo é composto pelos tempos de ida e volta do fóton entre estes espelhos. Na atividade, o relógio de luz é simplificado e o tempo considerado é a duração entre o disparo de um pulso de luz e sua detecção.

O terceiro elemento é a compreensão da pergunta relacionada à duração entre dois eventos. É necessário clareza quanto ao que se deseja observar e não é incomum o uso da expressão "tempo do referencial do esqueitista" ou "tempo do referencial do chão". Essas expressões podem dar a entender que o tempo é de algum modo colado nos referenciais. De fato, considera-se a existência de dois referenciais, mas a ideia é calcular o tempo entre eventos, o disparo e a detecção no relógio de luz, a partir destes dois referenciais. Portanto não há "tempo" nos referenciais, mas sim medidas a partir deles.

Ao final da atividade, espera-se que o aluno perceba que a estruturação do modelo físico é consistente. A dependência matemática entre diferenciação e velocidade apresentada na atividade 2 retorna melhor desenvolvida na articulação do experimento de pensamento, pois indica como e quais elementos devem ser observados. Entretanto, a estruturação matemática que permite expandir o pensamento a situações além da exemplificada não é abordada. Assim, o fluxo das atividades aponta a sequência para a estruturação matemática do fenômeno de diferenciação.

\subsubsection{Atividade 5-R-Luz algébrico}

A sequência como um todo busca um gradiente em direção à abstração para que ocorra a estruturação do pensamento relativístico. As primeiras abordagens matemáticas da sequência aparecem em relações simples de porcentagem na atividade 2. $\mathrm{Na}$ atividade 4 , essa estruturação é promovida por meio de relações 
matemáticas qualitativas e experimento de pensamento. A atividade 5 é complementar à 4 e procura fornecer subsídios matemáticos para a dinamização do modelo desenvolvido na atividade anterior.

Deste modo, o desenvolvimento dos quesitos matemáticos que estruturam o pensar sobre diferenciação temporal é o objetivo desta atividade. O obstáculo centralmente atacado nesta atividade é o da linguagem/formalização, pois se procura ressaltar mais o caminho para alcançar o resultado final e menos o resultado final em si.

A atividade retoma a situação proposta na atividade 4 com base em anotações fictícias de um aluno. A linguagem é modificada na busca de adequação à escrita de um jovem. Diversos detalhes críticos são abordados nesse material como uma forma de refinar a formulação da situação e a linguagem empregada. Dúvidas comuns, deslizes conceituais e estratégias de resolução são incluídos nas anotações para serem discutidas com o professor na primeira parte da atividade.

Dentre esses detalhes, ataca-se a abordagem da representação da luz como materializada e o uso de palavras como "referencial" e "evento" com maior intensidade para distingui-las do senso comum. O professor conta com um material de apoio que colabora na localização e abordagem destes pontos.

$\mathrm{Na}$ segunda parte da atividade, o relógio de luz é abordado num viés matemático atribuindo um caráter tradicional à atividade enquanto explora a função Y(v) da diferenciação temporal.

\subsubsection{Atividade 6 - Referencial Paradoxal}

O Paradoxo dos Gêmeos é uma situação complexa que necessita de conhecimentos físicos para ser compreendida. É comum ouvir as pessoas comentarem sobre o Paradoxo dos Gêmeos quando o assunto é Relatividade, ao se perguntar para um leigo sobre o que é efetivamente o Paradoxo, provavelmente ele responderá algo parecido com: "trata-se daquela situação em que um gêmeo faz uma viagem espacial enquanto o outro fica esperando na Terra. Quando o viajante retorna, um dos gêmeos está mais jovem".

A explicação hipotética representa bem a situação que compõe o Paradoxo, mas ressalta uma concepção parcial sobre qual é o paradoxo de fato. Ter pessoas 
nascidas no mesmo dia com idades diferentes é uma condição paradoxal tendo em vista a expectativa clássica de que o tempo flui da mesma forma para todos. Para a maioria dos leigos, o paradoxo está no fato de um dos gêmeos possui idades diferentes ao final da viagem. Esse paradoxo é real no contexto clássico, mas não reflete completamente o Paradoxo dos Gêmeos verdadeiro.

O Paradoxo verdadeiro não está só na diferença de idades entre os gêmeos. Seu núcleo conceitual está na aparente assimetria existente entre referenciais inerciais segundo a concepção apresentada pela RR. Tendo em mente que a diferenciação do tempo ocorre entre dois referenciais com velocidade relativa e que as leis físicas são idênticas para quaisquer referenciais inerciais, o problema surge quando se procura comparar as perspectivas advindas de observadores em ambos os referenciais.

Tomando a situação clássica em que um irmão fica na Terra e outro viaja em alta velocidade para depois retornar, pode-se formular o paradoxo: se o movimento é algo relativo a um referencial, na perspectiva do irmão que fica na Terra é o Gêmeo na nave quem se move, pois aquele assume a superfície terrestre como referencial inercial. Mas para o irmão na nave é seu irmão na Terra quem se move, pois o primeiro toma a nave como referencial inercial. Desta forma, não haveria como explicar o envelhecimento mais lento do irmão astronauta pelo fato dele estar em alta velocidade pois a situação seria simétrica e ambos acreditariam que o outro envelheceria mais lentamente. Entretanto, no reencontro, um deles vivenciou menos tempo do que o outro. Qual é o critério que definiria qual dos gêmeos viajou? Cria-se aí o paradoxo!

A atividade 6 possui caráter introdutório convida o aluno a compreender 0 Paradoxo dos Gêmeos com base na existência de uma falsa simetria entre os referenciais inerciais.

Com base em experiências anteriores, a sequência trabalha com a hipótese de que o Paradoxo dos Gêmeos é compreendido de forma superficial pelos alunos. Para os alunos que já ouviram falar sobre o paradoxo, é recorrente a concepção de que o paradoxo existe "porque gêmeos nascidos ao mesmo tempo, depois de uma viagem, passam a ter idades diferentes". De fato, essa explicação fica subentendida até a atividade 6 porque explicar a essência do paradoxo exigiria conceitos ainda não abordados. 
Tomando como necessidade a compreensão do paradoxo, o objetivo desta atividade é apresentar o que são referenciais inerciais e quais são suas características. Para tanto um jogo didático é planejado: os grupos devem produzir vídeos simples que gerem dúvidas sobre o que foi movimentado, a câmera ou o objeto filmado. Ao serem reproduzidos em classe, ganhará pontos aqueles vídeos que tornarem indistinguíveis a ação que foi feita e enganarem os grupos adversários. A discussão sobre referenciais e a abordagem do paradoxo surge a partir deste contexto.

A associação de um jogo, RR e recursos audio-visuais promove uma aula muito distinta das comuns. Assim, o maior obstáculo enfrentado nesta atividade foi o didático-pedagógico que está relacionado ao tipo de atividade e forma de aplicação.

\subsubsection{Atividade 7 - Eventos}

Os estudos sobre o relógio de luz exigem uma imaginação razoável por parte dos alunos porque eles precisam explorar um par de eventos a partir de dois referenciais tendo em mente que o movimento interfere no tempo. Entretanto, a enunciação do Paradoxo dos Gêmeos exige uma capacidade de visualização muito mais detalhada, que duplica o problema e não deixa claro quais eventos são importantes. A solução do paradoxo vem da compreensão e utilização do intervalo relativístico, o qual é apresentado como um conceito absoluto em relatividade de forma análoga ao papel que o tempo clássico assume na física clássica.

Nas atividades finais, trabalhou-se com a hipótese de que a compreensão do Paradoxo dos Gêmeos se torna difícil se os recursos utilizados forem somente a problematização associada a desenhos representativos como é feito na atividade 4 . A solução foi a utilização de representações diagramáticas do espaço-tempo.

Deste modo, um dos desafios que permeiam as atividades finais foi o estudo da RR por meio de interpretação gráfica. Ela é, sem dúvidas, uma ótima forma de interpretar fenômenos relativísticos permitindo a visualização completa da situação dos gêmeos em um único desenho. Entretanto, sua correta interpretação exigiu a compreensão de novos elementos e habilidades como a representação de evento, o significado dos eixos espacial e temporal no diagrama, a disposição destes eixos que são desenhados de forma inversa aos gráficos cinemáticos clássicos e as 
unidades de medida.

A atividade 7 promove a compreensão do caráter absoluto de um evento em relação a um referencial, assim como sua representação no diagrama de espaçotempo. Foram discutidas as posições dos eixos e o significado das linhas de mundo na expectativa de instrumentalizar o aluno para as atividades seguintes.

A situação problematizadora é apresentada por meio de um acidente de carro em uma esquina que resultou na morte de um motorista. Os grupos precisam reconstituir os eventos que antecederam o acidente para compreender o que realmente aconteceu. Cada grupo de investigadores possui um depoimento vindo de um personagem diferente. Os principais eventos devem ser representados em um diagrama similar ao diagrama espaço-tempo para posteriormente ser compartilhado com a turma em forma de diagrama. O professor então articula os diagramas dos alunos e reconstitui o acidente. Ao final, ele apresenta uma última perspectiva do que aconteceu por meio de um depoimento póstumo do falecido.

O obstáculo presente nesta atividade é o didático-pedagógico relacionado ao tipo de atividade. Há necessidade de uma grande articulação do professor para reunir as informações diversas vindas dos depoimentos dos alunos. Como a atividade tem caráter instrumentalizador, a questão sobre como aplicar as noções de evento para solucionar o paradoxo devem conectar esta atividade com a seguinte.

\subsubsection{Atividade 8-Caminhoneiros Relativísticos}

Esta atividade tem o objetivo-obstáculo central focado na linguagem/formalização. Tendo como pano de fundo a busca pela solução do Paradoxo dos Gêmeos, esta atividade busca apresentar o intervalo relativístico como o novo conceito absoluto.

A situação é dada por um texto futurístico onde caminhoneiros e empregadores discordam sobre o prazo de entregas de produtos. Enquanto o empregador exige o pagamento de multas pela demora nas entregas, os caminhoneiros afirmam que as entregas foram efetuadas dentro do prazo. O caso segue para um tribunal onde o intervalo relativístico aparece como uma solução, já que é invariante por mudanças de referencial.

A formulação precisa do intervalo relativístico é, além de inviável, 
indesejável, assim sua abordagem é feita em analogia com o teorema de Pitágoras. De fato, o sentido de invariância por referencial presente nas distâncias calculadas utilizando o teorema de Pitágoras tem equivalência com o sentido de intervalo calculado utilizando o intervalo relativístico.

Diferentemente dos eixos clássicos, as coordenadas temporais e espaciais possuem a mesma unidade (anos-luz) promovendo a discussão sobre a noção de espaço-tempo. Apesar de comumente desejada, essa discussão não é levada com profundidade devido à limitação de tempo disponibilizado para a sequência. Entretanto, uma possível discussão sobre o que é espaço e sua relatividade poderia ter esta atividade como ponto de contato caso uma segunda estrutura didática possuísse um fluxo ortogonal ao desta sequência. O principal obstáculo enfrentado é o da estruturação conceitual.

Outro ponto discutido são as unidades utilizadas para a localização dos eventos. Unidades como metro ou quilômetro e segundo ou dias não são apropriados. Deste modo as relações entre anos, anos-luz e velocidade da luz são exploradas com base no problema apresentado.

\subsubsection{Atividade 9 - Viagem no espaço-tempo}

Esta atividade é conclusiva na sequência e apresenta um conjunto de problemas que objetiva unir a questão posta na atividade 6 , a representação geométrica da atividade 7 e o intervalo relativístico discutido na atividade 8 para a solução final do Paradoxo dos Gêmeos. A ideia é mostrar graficamente que a situação de separação e reencontro dos gêmeos após uma viajem espacial não é de fato simétrica porque o gêmeo que viaja percorre dois intervalos relativísticos em referenciais distintos enquanto o gêmeo que fica na Terra percorre apenas um intervalo relativístico justamente por nunca mudar de referencial.

Mesmo que o aluno compreenda perfeitamente a situação e entenda como o intervalo relativístico esclarece a diferença de idades, a conclusão final ainda pode ser incorreta. Não é incomum, mesmo entre os professores, frases do tipo: "um dos gêmeos fica mais jovem do que o outro após a viagem". Essa conclusão está incorreta porque, na verdade, um dos gêmeos envelhece menos do que o outro. Esse detalhe crítico pode gerar a ideia completamente errada de que um dos 
gêmeos rejuvenesce ou volta no tempo quando viaja e retorna num foguete em alta velocidade.

Outro detalhe presente nesta atividade está no diagrama espaço-tempo. É importante que esteja claro que o diagrama sempre é desenhado sobre um referencial. Isso significa que a sua representação é relativa àquele referencial. $\mathrm{Na}$ sequência didática, todas as representações diagramáticas deste tipo são feitas no referencial da Terra.

\subsubsection{Avaliação}

O instrumento de avaliação utilizado durante o curso consiste no próprio instrumento de avaliação do fluxo, que neste caso, cumpriu dupla função. A partir da perspectiva do aluno, a avaliação local promove uma dissertação sintética individual que sistematiza os conhecimentos recentemente tratados. Na perspectiva do professor, a função desta avaliação é acessar informações rápidas e constantes sobre a interpretação dos alunos quanto aos objetivos centrais da atividade que foi feita. O professor também pôde utilizá-la como feedback de sua própria atuação com relação aos objetivos originalmente indicados.

\subsection{INSTRUMENTO DE FLUXO}

O instrumento de fluxo tem como objetivo analisar o fluxo por meio da percepção que os alunos desenvolvem exatamente após cada atividade. Dessa forma, os dados são caracterizados por serem informações locais e momentâneas. Trata-se de uma sequência "fotográfica" dos momentos de transição da sequência. Pretende-se verificar como a percepção de continuidade da sequência evolui com o passar das atividades.

É importante observar que o dado de pesquisa relacionado a esta percepção não depende somente do aluno, mas também do professor e do próprio material. Assim, ainda que a análise foque majoritariamente nas respostas dos alunos, considera-se que o resultado encontrado será produto de todo o processo. 
Se fosse pretendido associar a ideia de qualidade didática aos resultados da pesquisa, seria possível dizer que sequência terá mais ou menos qualidade conforme o reconhecimento de sua estrutura segundo a moral da história e a fluência presentes no diagrama de fluxo. Ou seja, terá maior qualidade conforme os objetivos centrais propostos no escopo da pesquisa forem alcançados. Nesta direção, o instrumento de fluxo se propõe a apresentar um perfil de fluência sobre a percepção dos alunos sobre o desenrolar das atividades em cada turma.

Para articular a análise, a construção das categorias associadas foram divididas em duas dimensões: dimensão de interface e dimensão de fluência. Essa divisão está diretamente vinculada às duas etapas necessárias para se responder o instrumento de fluxo.

A dimensão de interface tem a função de criar uma interface para diversidade de ideias apresentadas nas respostas dadas na $1^{\text {a }}$ etapa em graus de aproximação do que é esperado para cada atividade. Sua análise é feita a partir da primeira questão do instrumento de fluxo (veja a figura 10) e varia dependendo da atividade a que se refere.

A atribuição de categorias às respostas da $1^{\text {a }}$ etapa depende muito da percepção do pesquisador durante a associação das respostas aos objetivos e moral da história de cada atividade. Assim, para montar um critério simples, foram desenvolvidas duas grandes categorias diretas e antagônicas referentes às respostas que se aproximam do fluxo proposto e àquelas que se afastam dele. Uma terceira categoria agrupa as respostas que foram deixadas em branco ou que não foram corretamente preenchidas. Abaixo segue a descrição de cada categoria.

AproxMH - Aproxima-se da moral da história: essa categoria reúne as respostas que revelam compreensão suficiente da moral da história da atividade que acabara de ser feita. Essa categoria é composta por duas subcategorias: a $\operatorname{AproxMH(a)~e~a~AproxMH(b).~}$

A subcategoria AproxMH(a) reúne as respostas que se aproximam dos critérios produzidos previamente à análise dos dados, pela instância de pesquisa, e correspondem a uma idealização de respostas que convergiriam para a moral da história em cada atividade. Os parâmetros para as respostas $\mathrm{AproxMH(a)} \mathrm{podem} \mathrm{ser}$ vistos no quadro 10 "Parâmetros de respostas AproxMH(a)".

A subcategoria AproxMH(b) agrupa as respostas não vinculadas totalmente com a moral da história, mas que possuem raízes nos objetivos das atividades de tal 
forma que foram consideradas convergentes ao fluxo. A criação dos critérios para essa subcategoria faz parte da análise dos dados.

AfastMH - Afasta-se da moral da história: Reúne as respostas que revelam compreensão diversa ou insuficiente da moral da história da atividade que acabara de ser feita. A presença de uma resposta nessa categoria não significa que o aluno correspondente tenha deixado de construir conhecimento relevante em outros aspectos não analisados.

Branc/Incorr - Em branco ou incorretamente preenchidas: Reúnem as fichas que foram deixadas com a $1^{\text {a }}$ etapa em branco, sugeriram cópia ou não foram corretamente preenchidas.

A exemplificação de todas as categorias para cada uma das atividades está apresentada na seção de análise para organizar a leitura do texto. O leitor poderá ver tais exemplos na seção Exemplos e Análise da Dimensão de Interface na página 122.

\begin{tabular}{cl}
\hline Atividade & \multicolumn{1}{c}{ Parâmetros de respostas AproxMH(a) } \\
\hline 1 & $\begin{array}{l}\text { A resposta indica que o tempo físico tem maior pertinência quando se está tratando de } \\
\text { fenômenos físicos relativísticos. }\end{array}$ \\
2 & $\begin{array}{l}\text { A resposta indica que o fenômeno ocorre a todo momento mesmo que não percebamos sua } \\
\text { influência no cotidiano [\&] }]^{25} \text { é imperceptível em condições físicas onde as velocidades são baixas. } \\
\text { Há generalização do fenômeno. }\end{array}$ \\
3 & $\begin{array}{l}\text { Resposta que explica a palavra "relativo" como algo dependente de outra coisa com base nas } \\
\text { ideias de Einstein e Newton apresentadas na atividade 3. O conceito de evento ou a velocidade } \\
\text { da luz são os elementos não relativos esperados. }\end{array}$ \\
4 & $\begin{array}{l}\text { A constância da velocidade da luz está relacionada aos pontos de vista ou referenciais. Não deve } \\
\text { estar associada à constância de velocidade cinemática. }\end{array}$ \\
5 & $\begin{array}{l}\text { Considera as respostas que consideram o referencial próprio como aquele onde os eventos } \\
\text { importantes ocorrem no mesmo lugar. }\end{array}$ \\
6 & $\begin{array}{l}\text { Explicação associa o paradoxo, simetria dos referenciais e passagem do tempo nos referenciais. } \\
\text { A resposta apresenta a solução v=0,5m/s. }\end{array}$ \\
8 & $\begin{array}{l}\text { Respostas que expliquem algum tipo de invariância como o intervalo relativístico, a constância da } \\
\text { velocidade da luz ou dos eventos. } \\
\text { Respostas que expliquem a diferença de idade com base em diferenças nas linhas de mundo de } \\
\text { cada irmão. }\end{array}$ \\
\hline
\end{tabular}

Quadro 10: Parâmetros utilizados para categorização das respostas em AproxMH(a) - critério idealizado.

É importante salientar que a categorização de uma resposta em AproxMH não significa necessariamente que o aluno compreendeu a atividade mais do que o

25 O símbolo [\&] deverá ser lido conforme a lógica booleana, ou seja, são necessárias as duas condições para que a resposta pertença à categoria. 
colega que teve a resposta categorizada como AfastMH. As categorias AproxMH e AfastMH não possuem a pretensão de rotular, em níveis de compreensão, o que determinado aluno sabe sobre determinada atividade. Elas foram pensadas para refletirem a compreensão local e momentânea do núcleo da atividade com base na moral da história e objetivos de cada uma após seu término. Esse núcleo, mesmo que reconhecidamente importante, não se constitui em toda a abrangência das discussões feitas em classe, as quais podem transbordar em significados e conhecimentos além dos capturados por esse critério. Outro ponto importante, para que as categorias desta dimensão não sejam mal compreendidas, é que mesmo planejando que a moral da história seja percebida logo após a atividade, é esperado que em muitos casos uma ideia só seja aprendida futuramente, ao longo das atividades seguintes.

A dimensão de fluência tem função de organizar a percepção da fluência por meio das respostas dadas na $2^{\mathrm{a}}$ etapa. Como dito anteriormente, defende-se nessa pesquisa a hipótese de que o aluno imerso nas atividades de uma sequência construa um saber relacionado à fluência das atividades. A dimensão de fluência categoriza as respostas dos alunos para explicitar o quão "sincronizada" com o fluxo está a fluência de uma turma, ou seja, a percepção do fluxo segundo a perspectiva do aluno.

As categorias da dimensão de fluência seguem a definição de respostas tipo "passado", "presente" e "futuro" empregadas no instrumento de fluxo. O perfil de fluência é construído a partir da frequência com que os alunos escolhem as alternativas referentes a cada tipo.

Alternativas tipo presente: Elas foram construídas apontando os assuntos que efetivamente foram apresentados nas atividades feitas após o instrumento ter sido preenchido. A escolha desta alternativa pretende indicar a existência de concordância entre a percepção do aluno e o diagrama de fluxo da sequência. $\mathrm{Na}$ figura 10, presente na página 95, por exemplo, a opção (3) aponta diretamente para a atividade que efetivamente se iniciará a seguir - Atividade 3 Entrevista com Einstein e Newton.

Alternativas tipo passado: Elas se relacionam a assuntos que seriam possíveis de serem tratados pela atividade que acabara de ser concluída em classe. Para não tornar óbvia a intenção das questões, a construção destas alternativas não se basearam em assuntos efetivamente apresentados na sequência. Desta forma e 
a escolha desta alternativa indesejável significaria que, dentre as opções possíveis, o aluno acredita que a próxima atividade será qualitativamente igual à anterior, ou seja, a fluência apontaria contra o fluxo. Na figura 10, a alternativa (2) aponta para um assunto não existente no curso, mas cuja essência é considerada similar ao assunto já tratado na atividade 2 .

Alternativas tipo futuro: Elas se relacionam com assuntos que efetivamente aparecerão na sequência somente após a atividade subsequente. Deste modo, indicaria uma antecipação ou descompasso entre a percepção do aluno e o diagrama de fluxo. Essa escolha não é considerada tão problemática quanto às do tipo passado porque indicaria alguma sincronia com relação à direção do fluxo. No exemplo da figura 10, a escolha (1) aponta para as atividades 4 e 5 que tratarão da modelização do fenômeno da diferenciação.

No quadro 20 da página 108 estão apresentadas todas as escolhas criadas para representar as três categorias da dimensão de fluência.

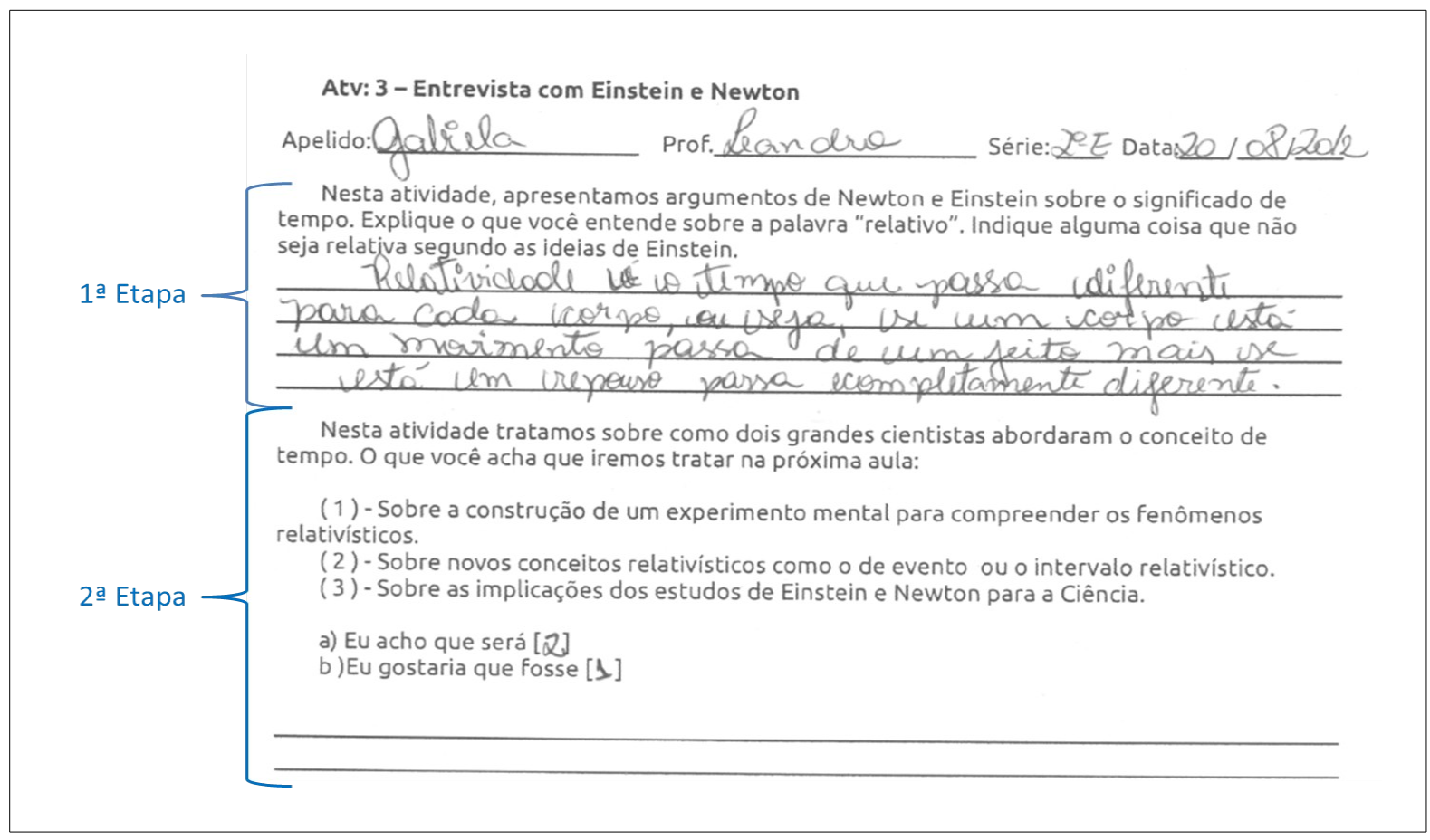

Figura 10 - Exemplo de instrumento de fluxo.

O instrumento em si é composto por uma ficha a ser respondida pelos alunos, individualmente, durante os últimos 5 minutos de cada atividade. Na figura 10 é possível observar um exemplar respondido por uma aluna da turma BR2E após 
a finalização da atividade 3 .

Para respondê-lo, o aluno deverá passar por duas etapas: a $1^{\text {a }}$ etapa é composta por uma questão dissertativa relacionada à atividade que acabara de ser feita; a $2^{a}$ etapa é composta por uma questão alternativa relacionada à fluência da sequência naquele momento didático.

Cada atividade possui uma ficha diferente $\mathrm{e}$ adaptada às suas particularidades. As questões dissertativas da $1^{\text {a }}$ etapa foram desenvolvidas com base na intersecção da moral da história e dos objetivos que cada atividade possui no caderno dos professores, conforme é esquematicamente representado pela figura 11 .

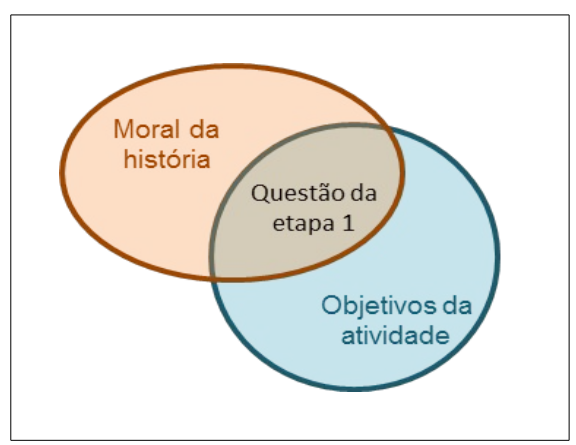

Figura 11 - Representação do desenvolvimento das questões da $1^{\text {a }}$ etapa. As questões tiveram construção pela intersecção da moral da história e dos objetivos de cada atividade.

A resposta desta primeira questão é categorizada pela dimensão de interface e pretende fornecer informações sobre o conhecimento construído na esfera do saber ensinado e sua convergência para a moral da história da atividade que acabara de ser feita.

A partir do quadro 11 até o quadro 19, estão apresentadas a moral da história, os objetivos presentes no material do professor para cada atividade e as questões formuladas com base nesses dois parâmetros. 


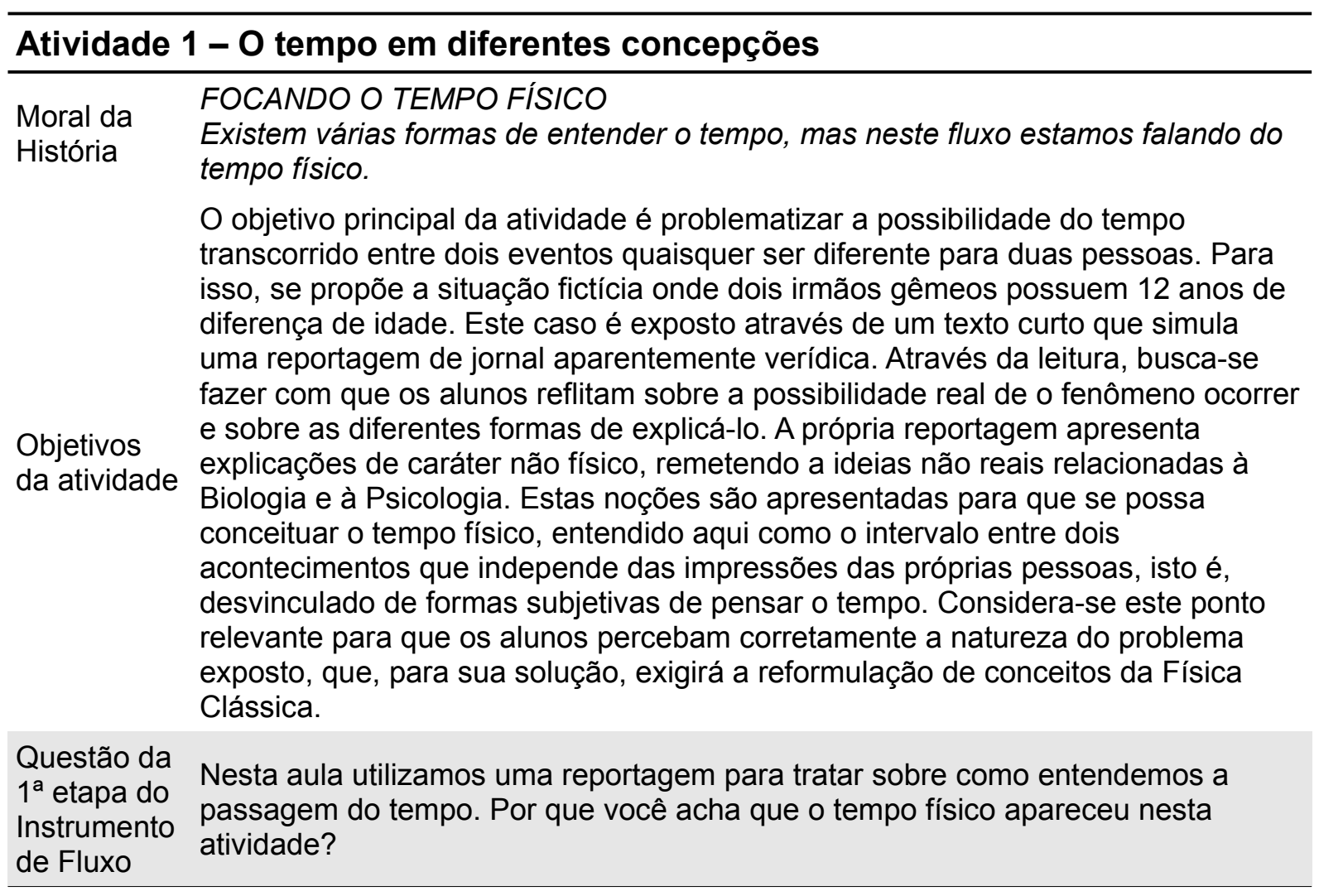

Quadro 11: Parâmetros de construção da questão dissertativa para o instrumento de fluxo da Atividade 1. 


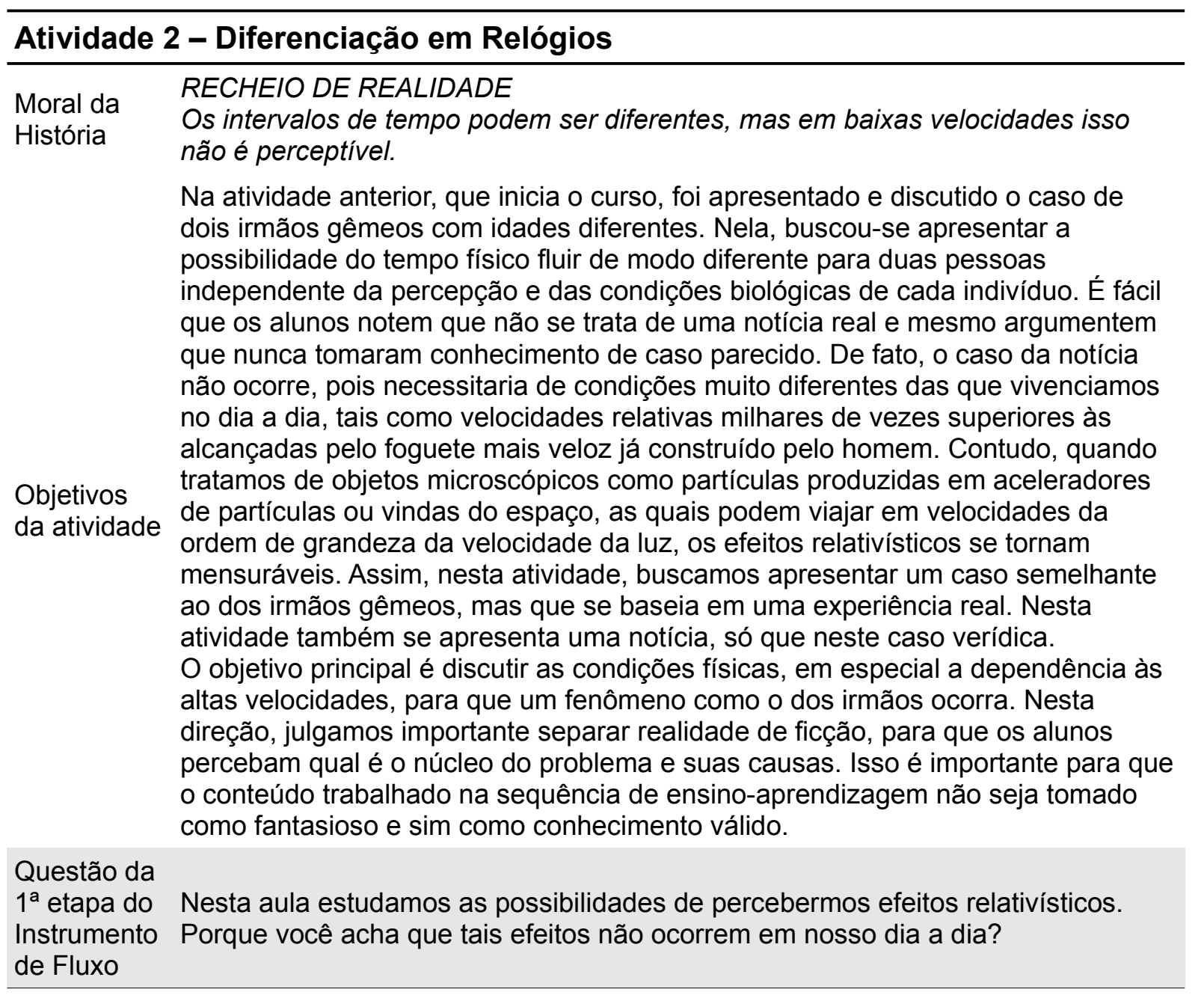

Quadro 12: Parâmetros de construção da questão dissertativa para o instrumento de fluxo da Atividade 2. 


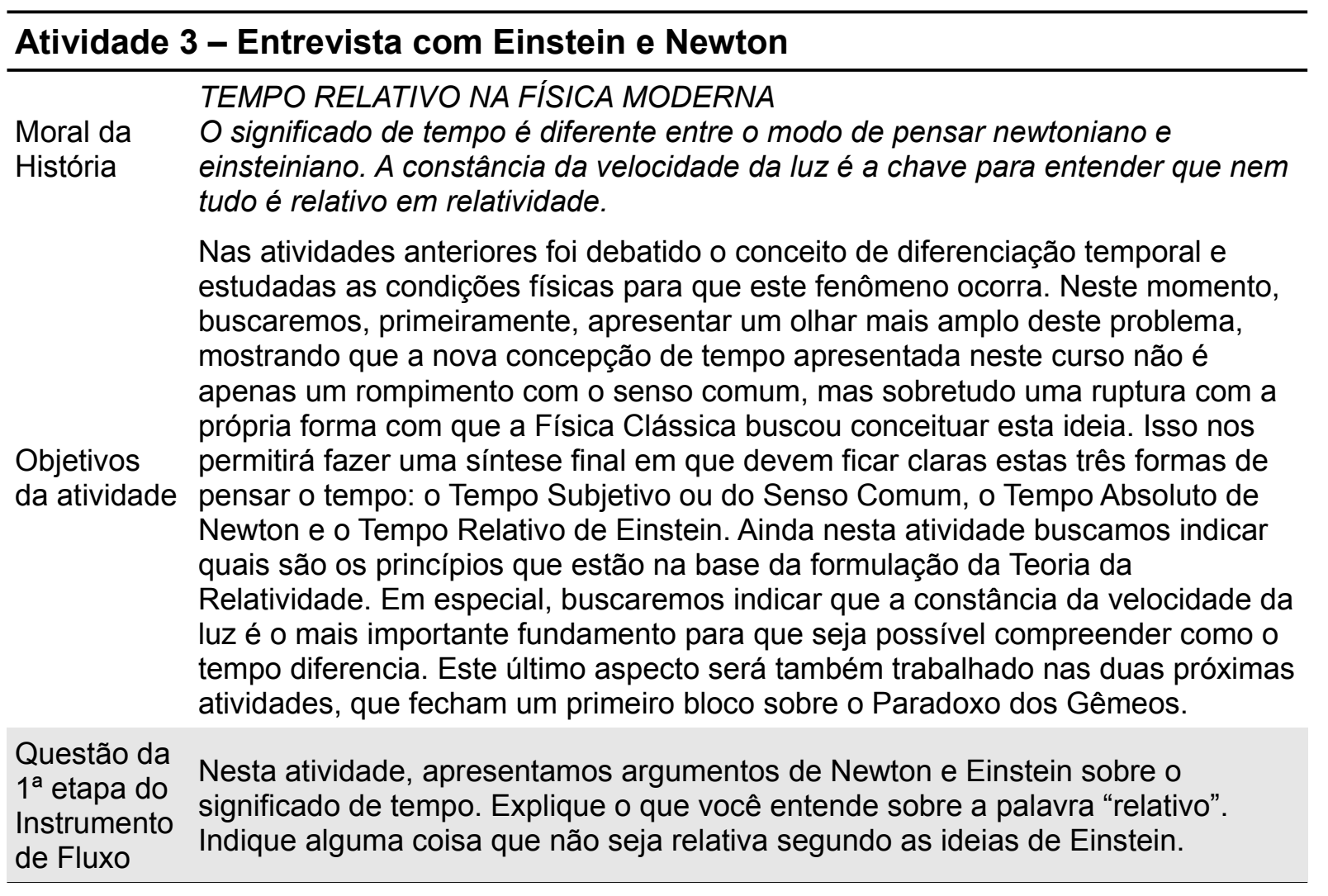

Quadro 13: Parâmetros para a construção da questão dissertativa para o instrumento de fluxo da Atividade 3. 


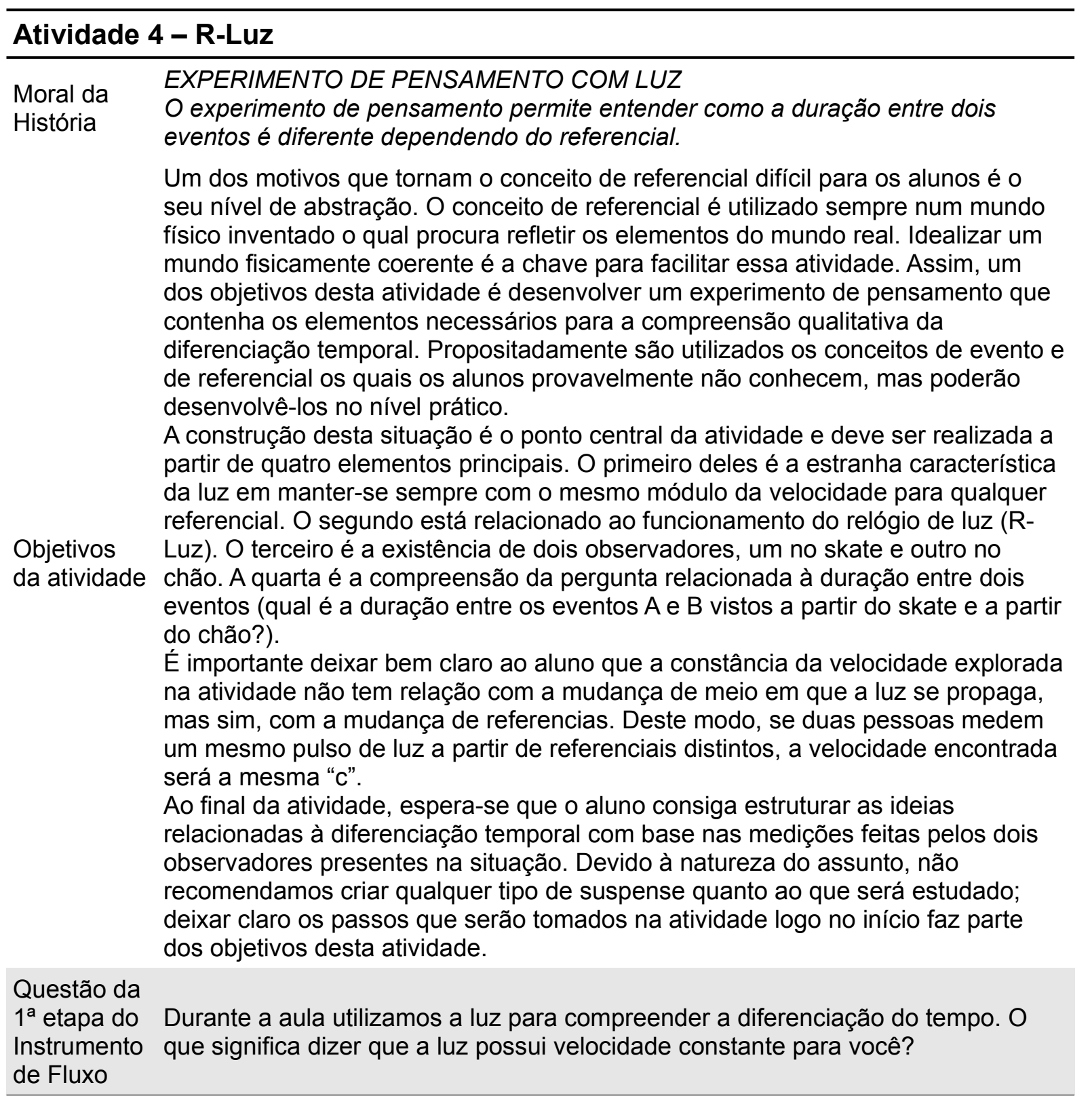

Quadro 14: Parâmetros para a construção da questão dissertativa para o instrumento de fluxo da Atividade 4. 


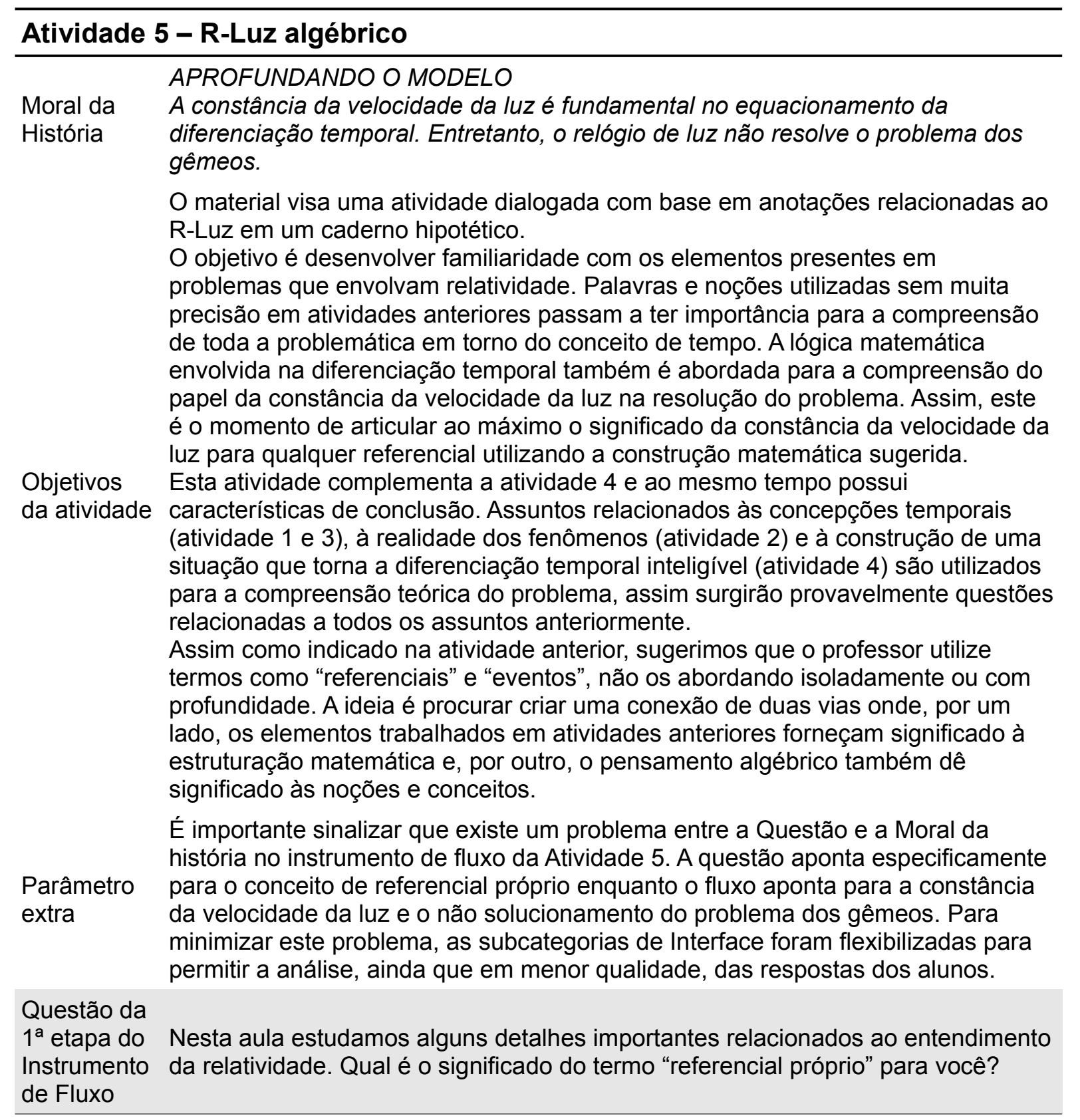

Quadro 15: Parâmetros para a construção da questão dissertativa para o instrumento de fluxo da Atividade 5. 


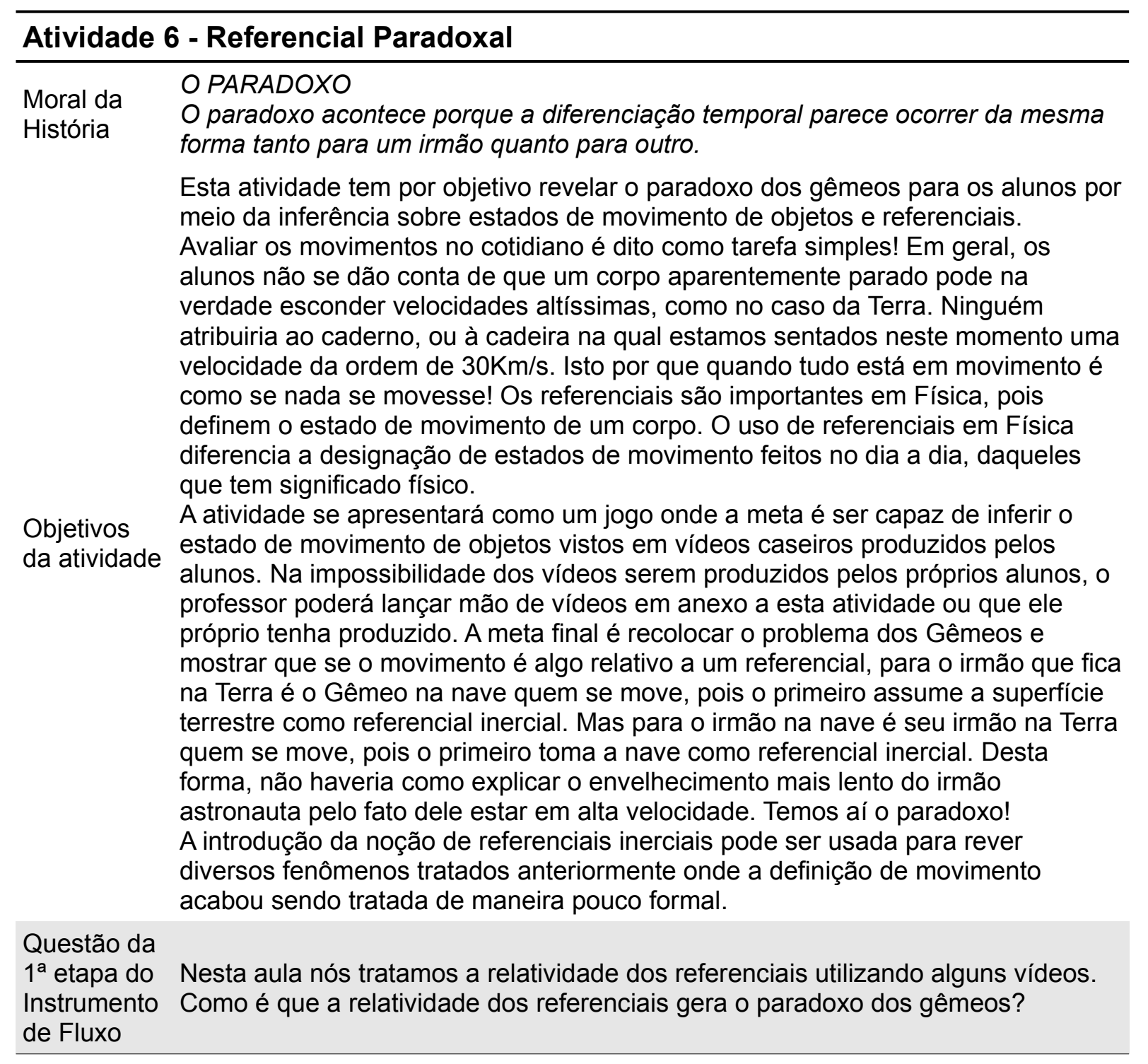

Quadro 16: Parâmetros para a construção da questão dissertativa para o instrumento de fluxo da Atividade 6. 


\begin{tabular}{ll}
\hline Atividade & 7 - Eventos \\
\hline Moral da & EVENTOS \\
História & $\begin{array}{l}\text { Eventos são ocorrências absolutas bem delimitadas no espaço e no tempo. A } \\
\text { existência dos eventos não depende do sistema de referência. }\end{array}$
\end{tabular}

Esta atividade foi desenvolvida para o primeiro contato com o conceito de evento, que consiste em um acontecimento pontual no espaço e no tempo. Como exemplos de eventos, podemos tomar a colisão entre dois carros ou o momento em que pomos nosso pé fora de casa, tais ocorrências bem localizadas no espaço e no tempo podem ser consideradas eventos.

Os eventos são importantes no ensino de relatividade porque eles são absolutos, isto é, permanecem inalterados independentemente de qualquer transformações relativística. Embora diferentes observadores possam descrever diferentemente um evento, podendo por exemplo discordar sobre o momento e o local onde ele ocorreu (suas coordenadas no espaço e no tempo), o fato de o evento ter

Objetivos da atividade construção do conjunto de noções futuramente trabalhadas.

Esperamos que os alunos consigam ao final da aula extrair onde e quando eventos comuns se manifestam. Para tanto é necessária a compreensão de sua representação no diagrama de espaço e tempo, o qual será importante para a solução de problemas relacionados à diferenciação do tempo. Com maior profundidade esperamos que o aluno compreenda o conceito de evento físico como uma representação abstrata dos acontecimentos no mundo.

É importante que o professor apresente mais alguns elementos que chamem a atenção para a noção de referenciais, mas sem apresentação formal. A noção de referencial vem sendo tratada ao longo do curso e acreditamos que seu significado já esteja sendo construído desde as atividades anteriores.

Questão da $1^{\text {a }}$ etapa do Instrumento de Fluxo
Hoje você viu que um conjunto de eventos ligados à existência de um objeto é chamada linha de mundo. Diga com que velocidade o carro ao lado criou os eventos representados por sua linha de mundo.

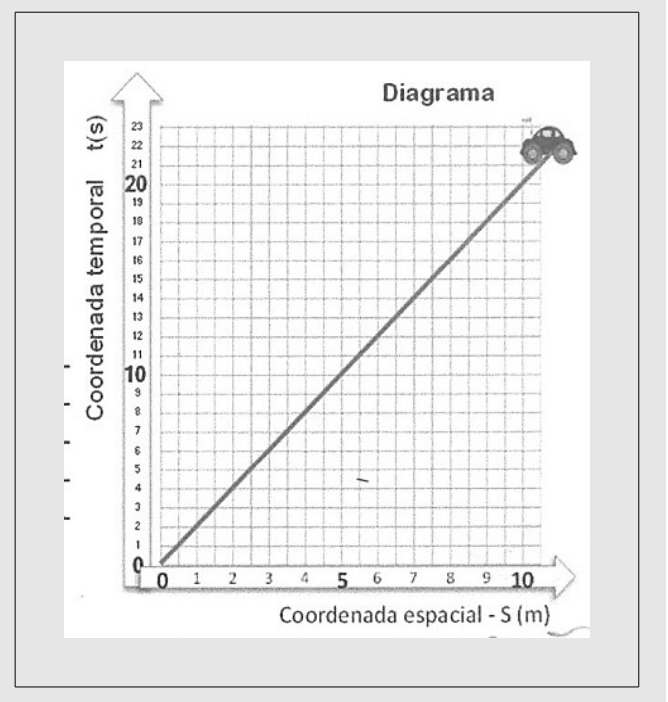

Figura 12 - Diagrama complementar à questão presente no instrumento de fluxo da atividade 7 .

Quadro 17: Parâmetros para a construção da questão dissertativa para o instrumento de fluxo da Atividade 7. 


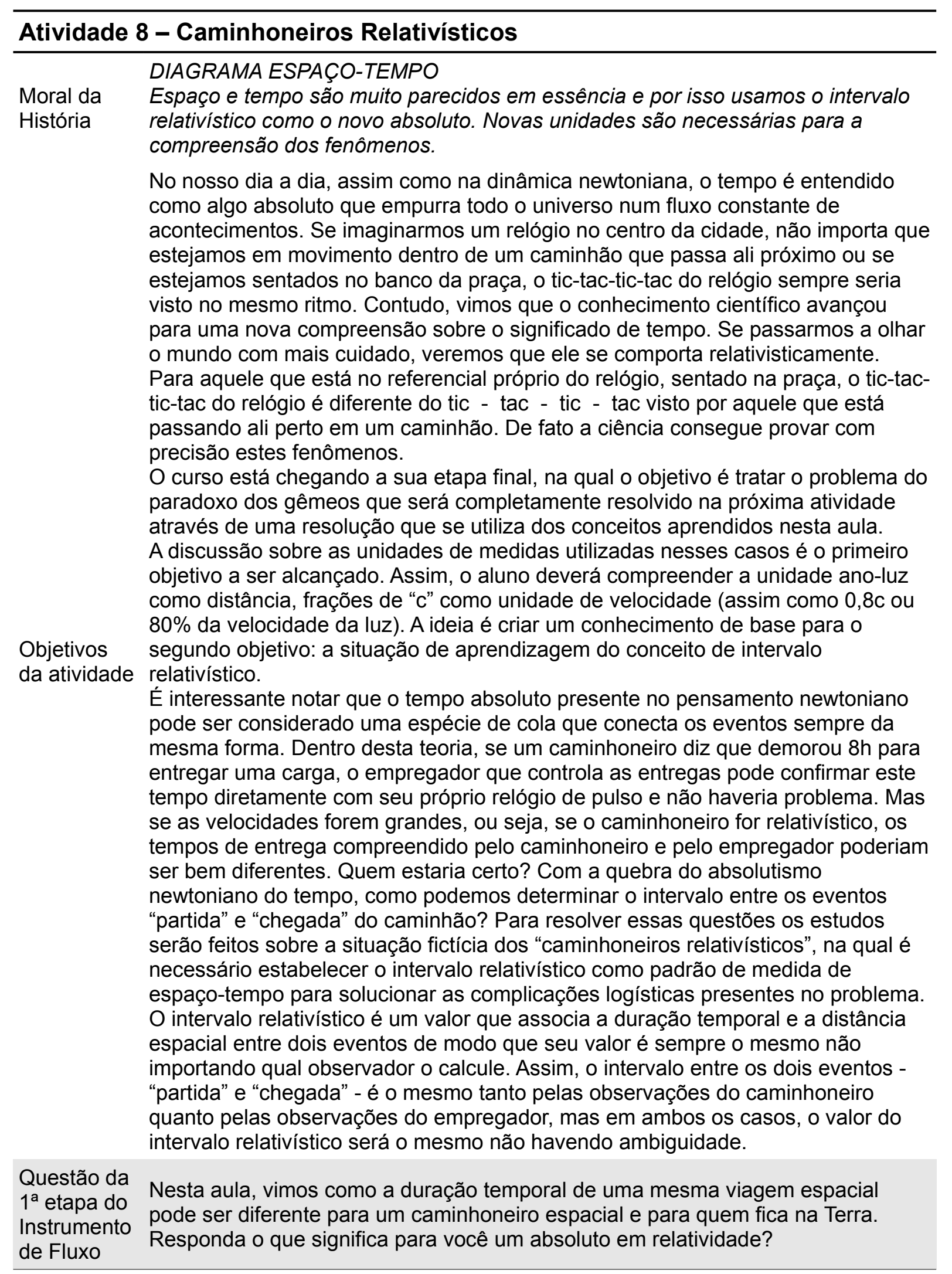

Quadro 18: Parâmetros para a construção da questão dissertativa para o instrumento de fluxo da Atividade 8. 


\section{$\overline{\text { Atividade } 9 \text { - Viagem no espaço-tempo }}$ \\ NÃO HÁ PARADOXO \\ Moral da Não há paradoxo porque os gêmeos não compartilham a mesma situação. $A$ \\ História duração entre dois eventos pode ser diferente para dois referenciais distintos, mas o intervalo relativístico é sempre o mesmo.}

Esta é a última atividade do curso e seu o objetivo é tratar e desvendar a falsidade do paradoxo dos gêmeos. A solução envolverá uma resolução geométrica num diagrama espaço-tempo referenciado na Terra. Sugerimos fortemente que sejam resgatados os elementos presentes em atividades anteriores durante a solução do paradoxo para que a totalidade do curso possa ser compreendida e validada pelos alunos. Esta atividade é de conclusão e deve ser aberta para que os alunos se expressem.

É objetivo desta atividade que o aluno compreenda que o paradoxo dos gêmeos é uma construção baseada numa simetria que não existe:

Se nos colocássemos no referencial de Adam, na Terra, veríamos Sheldon ir embora e voltar. Logo Sheldon envelheceria mais lentamente. Se nos colocássemos no referencial de Sheldon, na nave, veríamos Adam ir embora e voltar. Logo Adam e todo o planeta Terra envelheceria mais lentamente.

Sendo a situação aparentemente simétrica quando trocamos de referenciais, como poderiam ambos envelhecer diferentemente? Quem envelhece menos aquele que viaja ou o que fica na Terra?

A aparente simetria vem uma omissão importante na situação proposta: normalmente é omitido que o gêmeo viajante muda de referencial entre os eventos de partida e chegada. Isso faz toda a diferença nas descrições feitas pelo irmão que fica na Terra e pelo viajante, uma vez que o primeiro experimenta apenas um referencial entre os eventos de partida e chegada, já o irmão que viaja

Objetivos da atividade volta para a Terra.

experimenta um referencial durante a ida e um segundo referencial durante a

É importante compreender que o diagrama de espaço-tempo que tratamos aqui só pode ser construído se estiver "fixado" num referencial inercial. A construção de outro diagrama a partir do referencial do viajante exigiria habilidades matemáticas que não são tratadas durante o curso e por esse motivo não recomendamos qualquer tentativa em abordar esse aspecto.

É necessário também trabalhar a aula de modo a fazer com que os eixos do diagrama sejam bem compreendidos pelos alunos. O diagrama é construído por dois eixos coordenados: um deles é o bem conhecido eixo espacial na direção horizontal e o outro está totalmente relacionado com o tempo, mas não é o tempo propriamente dito. Certamente os alunos estranharão o fato de que a coordenada temporal presente no diagrama de espaço-tempo possui unidade de distância (anos-luz), mas isso é resultado da nova visão de mundo promovida pela relatividade einsteiniana. Nela os conceitos de espaço e tempo newtoniano são misturados permitindo-nos compreender o mundo não com 3 dimensões espaciais e 1 dimensão temporal, mas sim numa única estrutura quadridimensional (com 4 dimensões). Tais dimensões não se constituem nem coordenadas espaciais e nem temporais no sentido newtoniano, mas sim coordenadas espaço-temporais organizadas a partir da teoria da relatividade einsteiniana. Deste modo, é interessante indicar ao aluno que quando falamos em coordenada temporal no espaço quadridimensional, estamos falando sobre ct (em anos-luz) e não simplesmente em tempo (t).

Questão da $1^{a}$ etapa do Instrumento de Fluxo

Nesta aula finalizamos o curso de relatividade usando o intervalo relativístico na solução do paradoxo dos gêmeos. Explique porque é que o gêmeo que viaja envelhece mais lentamente que seu irmão que ficou na Terra.

Quadro 19: Parâmetros para a construção da questão dissertativa para o instrumento de fluxo da Atividade 9. 
$\mathrm{Na} 2^{\mathrm{a}}$ etapa, após responder a questão dissertativa, o aluno se depara com uma questão alternativa relacionada à percepção que o aluno cria a respeito da fluência da sequência. Para isso, uma frase inicial apresenta a essência da atividade conforme a perspectiva presente na moral da história relativa àquela atividade que acabara de participar.

O objetivo da frase inicial foi deixar explícita uma componente padronizada de informação para todos os alunos independentemente das diferentes perspectivas advindas dos raciocínios feitos durante a $1^{1 a}$ etapa Considera-se que essa afirmação inicial forneça ao aluno uma percepção local da estrutura do curso, informa sucintamente a função daquela atividade possibilitando uma melhor estimativa sobre qual seria o assunto da próxima atividade. No caso do exemplo presente na figura 10, a frase é "Nesta atividade tratamos sobre como dois grandes cientistas abordaram o conceito de tempo." A pergunta que se segue é: Sobre o que você acha que iremos falar na próxima atividade? A resposta é dada duas vezes, na primeira, o aluno aponta o que ele acha que será apresentado, na segunda o que ele gostaria que fosse apresentado. Entretanto, os perfis produzidos com base na segunda resposta não serão discutidos nessa análise. A justificativa desta $2^{\mathrm{a}}$ etapa foi opcional e considerada somente como confirmação da interpretação de algumas respostas.

A construção das fichas, assim como as categorias que serão apresentadas para a dimensão de interface, possui uma relação direta com o momento didático a que se referem. A produção de cada alternativa da $2^{a}$ etapa foi pensada para se vincular mais ou menos a elementos centrais presentes nas atividades que se posicionam adiante ou no passado da atividade que acabara de ser feita. Desta forma, as respostas são categorizáveis como tipo "passado", "presente" ou "futuro", conforme o conforme a figura 13.

O aluno poderá escolher, dentre as três alternativas, um assunto que se relaciona à atividades futuras, ou um assunto relacionado à atividade que efetivamente será iniciada naquele momento didático, ou ainda, poderá escolher um assunto relacionado à atividade que acabara de ser feita. $O$ perfil de fluência de uma determinada turma será feito a partir da categorização destas escolhas.

No quadro 20 é possível observar todo o conjunto de alternativas da $2^{\mathrm{a}}$ etapa. Para cada questão da $2^{\mathrm{a}}$ etapa existem 3 alternativas, cada uma se refere a uma das categorias da dimensão de fluência. 


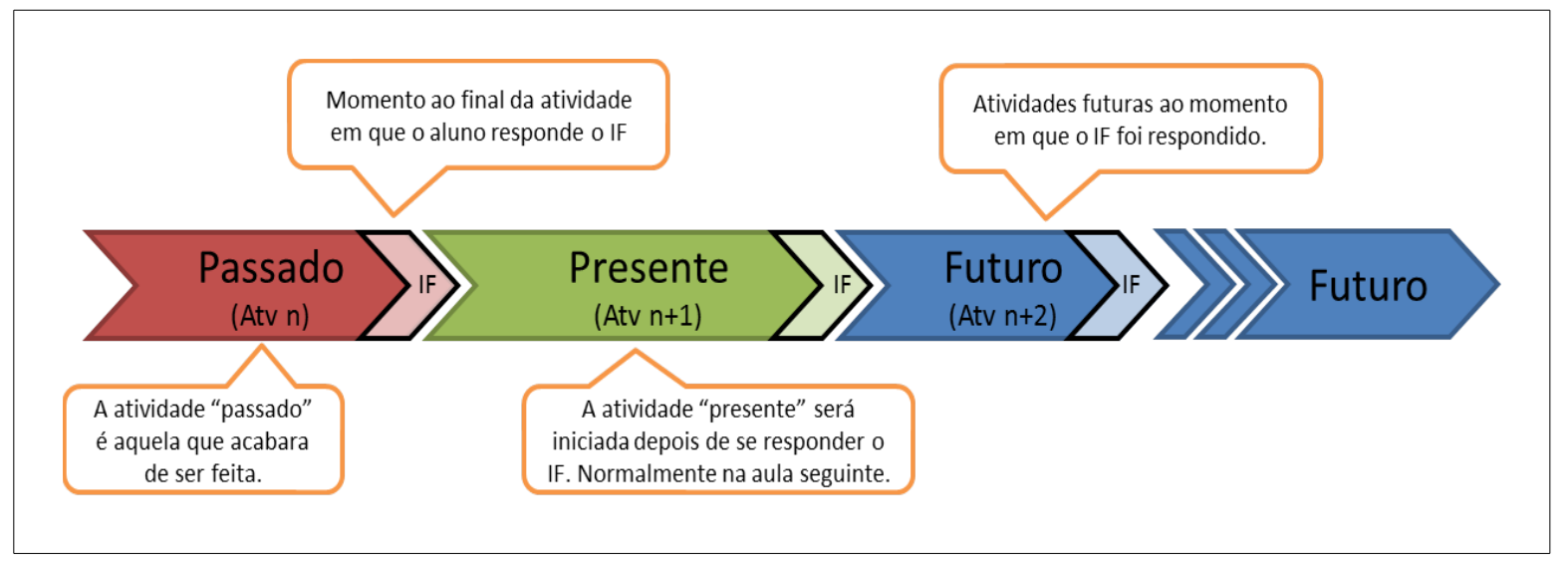

Figura 13 - Rotulação dos tempos didáticos com relação ao momento em que se responde o instrumento de fluxo (IF). 


\begin{tabular}{|c|c|c|c|}
\hline Atividade & Alternativas & Tipo & $\begin{array}{l}\text { Atividade } \\
\text { vinculada }\end{array}$ \\
\hline \multirow{3}{*}{1} & (1) - Tempo relacionado às sensações. & Passado & 1 \\
\hline & (2) - Tempo relacionado aos conceitos físicos. & Futuro & $4 ; 6 ; 7 ; 8$ \\
\hline & (3) - Tempo relacionado às medidas. & Presente & 2 \\
\hline \multirow{3}{*}{2} & (1) - A matemática por trás dos conceitos relativísticos. & Futuro & $4 ; 5$ \\
\hline & $\begin{array}{l}\text { (2) - Sobre os efeitos relativísticos nas pessoas e tecnologias } \\
\text { futuras. }\end{array}$ & Passado & 2 \\
\hline & (3) - Sobre como os cientistas trataram essas ideias no passado. & Presente & 3 \\
\hline \multirow{3}{*}{3} & $\begin{array}{l}\text { (1) - Sobre a construção de um experimento mental para } \\
\text { compreender os fenômenos relativísticos. }\end{array}$ & Presente & 4 \\
\hline & $\begin{array}{l}\text { (2) - Sobre novos conceitos relativísticos como o de evento ou o } \\
\text { intervalo relativístico. }\end{array}$ & Futuro & $6 ; 7 ; 8 ; 9$ \\
\hline & $\begin{array}{l}\text { (3) - Sobre as implicações dos estudos de Einstein e Newton para } \\
\text { a Ciência. }\end{array}$ & Passado & 3 \\
\hline \multirow{3}{*}{4} & (1) - Sobre ideias abstratas como "eventos" e "referenciais". & Futuro & $6 ; 7 ; 8 ; 9$ \\
\hline & $\begin{array}{l}\text { (2) - Sobre a estruturação algébrica usada para explicar o } \\
\text { experimento de pensamento. }\end{array}$ & Presente & 5 \\
\hline & $\begin{array}{l}\text { (3) - Sobre uma outra situação que nos ajuda a compreender os } \\
\text { fenômenos relativísticos. }\end{array}$ & Passado & 4 \\
\hline \multirow{3}{*}{5} & (1) - Sobre como os referenciais são equivalentes. & Presente & 6 \\
\hline & $\begin{array}{l}\text { (2) - Sobre gráficos e representações matemáticas usados em } \\
\text { relatividade. }\end{array}$ & Passado & 5 \\
\hline & (3) - Sobre intervalo relativístico. & Futuro & $8 ; 9$ \\
\hline \multirow{3}{*}{6} & $\begin{array}{l}\text { (1) - Sobre a solução do paradoxo dos gêmeos com base nas } \\
\text { atividades anteriores. }\end{array}$ & Futuro & $8 ; 9$ \\
\hline & $\begin{array}{l}\text { (2) - Sobre outros conceitos absolutos para a compreender a } \\
\text { solução do paradoxo. }\end{array}$ & Passado & 6 \\
\hline & $\begin{array}{l}\text { (3) - Sobre o diagrama espaço-tempo e sua relação com o } \\
\text { conceito de referenciais. }\end{array}$ & Presente & 7 \\
\hline \multirow{3}{*}{7} & $\begin{array}{l}\text { (1) - Sobre eventos em situações relativísticas representadas no } \\
\text { diagrama espaço-tempo. }\end{array}$ & Presente & 8 \\
\hline & (2) - Sobre a relatividade dos referenciais. & Passado & 7 \\
\hline & (3) - Sobre a solução do paradoxo dos gêmeos. & Futuro & 9 \\
\hline \multirow{3}{*}{8} & (1) - Sobre intervalo relativístico em 4 dimensões. & Futuro* & --- \\
\hline & (2) - Sobre a solução do paradoxo dos gêmeos. & Presente & 9 \\
\hline & $\begin{array}{l}\text { (3) - Sobre o desenvolvimento tecnológico relacionado com } \\
\text { viagens espaciais. }\end{array}$ & Passado & 8 \\
\hline \multirow{4}{*}{9} & (1) - Não satisfeito. & --- & --- \\
\hline & (2) - Razoavelmente satisfeito. & --- & --- \\
\hline & (3) - Satisfeito. & --- & --- \\
\hline & (4) - Plenamente satisfeito. & --- & --- \\
\hline
\end{tabular}

* Como não há atividades além da nona, essa alternativa foi criada para completar o instrumento.

Quadro 20: Alternativas criadas para a $2^{\mathrm{a}}$ etapa dos instrumentos de fluxo. 


\section{ANÁLISE}

No total, foram categorizadas 108 fichas das turmas BR3A, BR3E, BR2E, DEGr e DELe, 8 folhas foram descartadas por estarem em branco ou preenchidas incorretamente. Esse volume de informação e correlações foram organizadas utilizando o software de análise qualitativa Atlas.ti com base nos apontamentos de Weitzman, E. A (2000) sobre o uso crítico da ferramenta. As análises dos quadros e gráficos serão feitas por comparação de perfis.

\subsection{ANÁLISE DA PESQUISA AUXILIAR}

A seguir serão apresentadas análises para a etapa 1 e 2 de exemplares para cada categoria. Vale lembrar que a questão 3 e o instrumento de fluxo são instrumentos distintos.

\section{Respostas convergentes e coerentes (Conv\&Coer)}

Nesta categoria de resposta o aluno indicaria a permanência de uma linha de raciocínio vinculada a apenas um dos dois tipos de explicação durante as duas etapas. Suas justificativas revelariam maior estabilidade na percepção do contexto esperado no questionamento. Abaixo podemos ver dois exemplares desta categoria. 
Com céu aberto ao meio dia, o Sol brilha para todos!

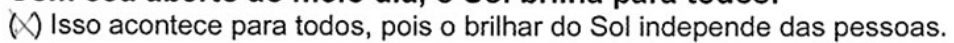

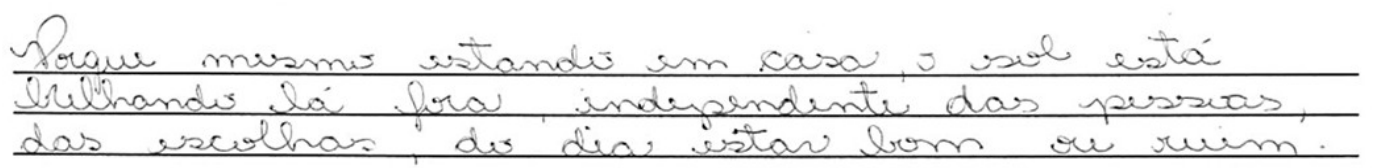

"Porque mesmo estando em casa, o sol está brilhando lá fora, independente das pessoas, das escolhas, do dia estar bom ou ruim."

Figura 14 - Exemplo de resposta Conv\&Coer etapa 1 - Turma BR 3E

Na justificativa da figura 14, a expressão "independente das pessoas" sugere a não dependência entre o brilhar do Sol e percepções pessoais ou mesmo entre fenômenos físicos não correlacionados assim como o clima. O tipo de explicação adotado foi o 1 neste caso.

Um animal nasce no meio de uma selva

() Isso acontece para todos, mesmo que não vejamos o filhote.

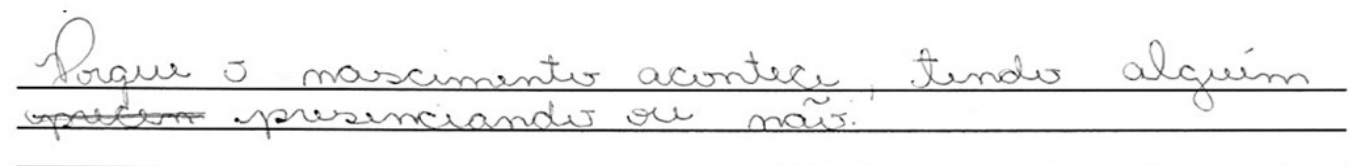

"Porque o nascimento acontece, tendo alguém presenciando ou não."

Figura 15 - Exemplo de resposta Conv\&Coer etapa 2 - Turma BR 3E

A mesma linha de raciocínio se repete na figura 15 tanto para a alternativa quanto para o tipo de explicação. A justificativa aparentemente indica que o nascimento simplesmente "acontece" com ou sem a presença de alguém significando que o fenômeno faz sentido mesmo sem observadores.

\section{Respostas divergentes e coerentes (Div\&Coer):}

A esse tipo de resposta se associa os alunos que não consideraram a existência de uma linha de raciocínio unificadora das duas afirmações. Entretanto, tais alunos justificaram coerentemente cada uma das alternativas escolhidas com base nos tipos. 


\section{Exemplo - Turma BR2E}

Com céu aberto ao meio dia, o Sol brilha para todos!

$\bigotimes$ Isso acontece somente para quem está sob o Sol, pois quem está fechado dentro de casa não percebe seu brilho naquele momento.

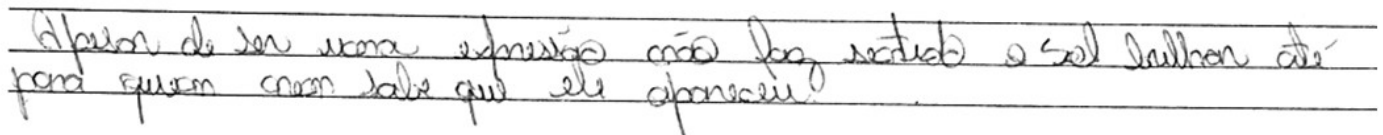

“Apesar de ser uma expressão não faz sentido o sol brilhar até para quem não sabe que ele apareceu."

Figura 16 - Exemplo de resposta Div\&Coer etapa 1 - Turma BR 2E

Na primeira etapa presente na figura 16 , considera-se que a justificativa do aluno está coerente com a explicação tipo 2, pois mesmo que o aluno tenha considerado que a frase vem da expressão popular, ele reconhece o contexto não literário e considera o brilhar do Sol como um acontecimento apenas para quem "sabe que ele apareceu".

Um animal nasce no meio de uma selva

$(X)$ Isso acontece para todos, mesmo que não vejamos o filhote.

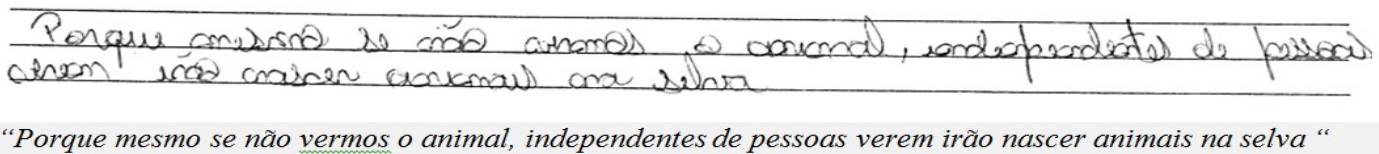

Figura 17 - Exemplo de resposta Div\&Coer etapa 2 - Turma BR 2E

$\mathrm{Na}$ justificativa da figura 17 é possível observar a independência que o acontecimento "nascer" tem com relação aos observadores quando é afirmado que "independentes de pessoas verem irão nascer". Desta vez a justificativa e a escolha apontam para a explicação do tipo 1.

Esta resposta particularmente exibe a interessante característica de ir contra praticamente todas as tentativas de contextualização do instrumento sem perder coerência. Ela toma o astronômico e evidente brilho do Sol como dependente de observação ao passo que o secreto e afetivo nascimento na floresta seriam independentes de observadores. 


\section{Respostas convergentes e incoerentes (Conv\&Incoer)}

As justificativas desta categoria puderam ser divididas em dois grandes grupos importantes. No primeiro grupo se encontram as justificativas diferentes e fora do contexto de pesquisa. Dentre elas, destaca-se as que consideram uma interpretação diferente da palavra "todos", como será apresentado no exemplo a seguir. No segundo grupo, encontram-se as justificativas que aparentemente utilizam as explicações tipo 1 ou 2 de forma invertida da esperada, por exemplo, aplica-se a justificativa tipo 2 para uma alternativa tipo 1. Estes grupos não foram colocados em subcategorias, pois o objetivo deste instrumento não foi o de analisar todas as possíveis perspectivas que os alunos podem trazer ao lerem as afirmações.

\section{Exemplo - Turma BR3A}

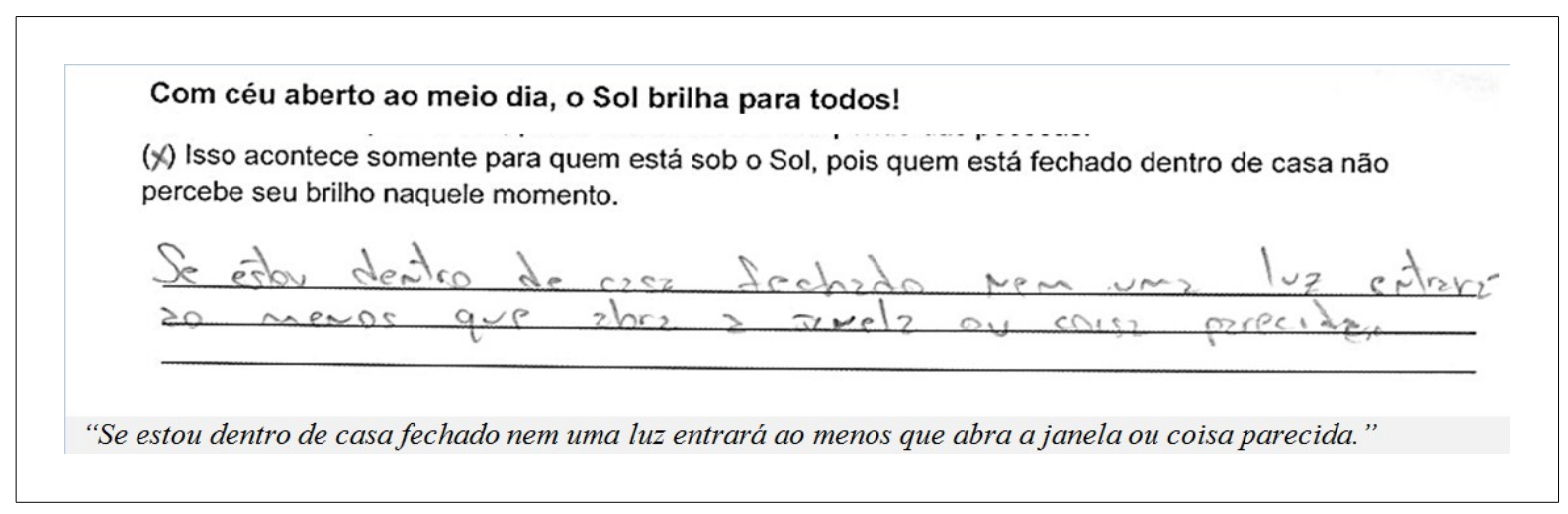

Figura 18 - Exemplo de resposta Conv\&Incoer etapa 1 - Turma BR3A

$\mathrm{Na}$ etapa 1 presente na figura 18, o aluno parece acreditar que faz mais sentido relacionar o brilhar do Sol com sua própria percepção. A alternativa e justificativa do aluno são coerentes com o tipo 2 de explicação uma vez que relaciona o brilhar à presença de observadores.

Um animal nasce no meio de uma selva

$($ Isso acontece somente para o animal e sua mãe, pois ninguém mais sabe sobre o nascimento.

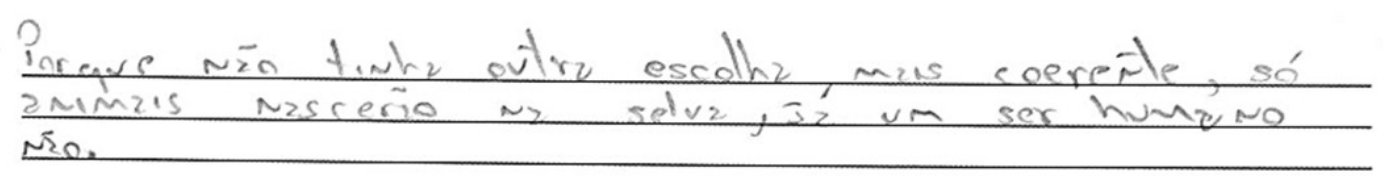

"Porque não tinha outra escolha, mais coerente, só animais nascerão na selva, já um ser humano não."

Figura 19 - Exemplo de resposta Conv\&Incoer etapa 2 - Turma BR3A 
$\mathrm{Na}$ segunda etapa, presente na figura 19, a justificativa exibe uma característica importante que surgiu em outras respostas. A sentença "Isso acontece para todos" nas demais alternativas pode significar tanto "todas as pessoas" como "todos os animais". Com base nessa dupla interpretação, alguns alunos conduziram justificativas diferentes dos tipos 1 e 2. No caso exemplificado aqui, a lógica referida pelo aluno reside no fato de que se um animal nasceu no meio da selva, logo ele não pode ser um homem. Então o aluno não poderia escolher nem a primeira e nem a segunda alternativa, pois o homem, ainda que seja um animal, não nasce em selvas. Restou apenas a última alternativa que não inclui a localidade do nascimento e mantém a coerência segundo a lógica do aluno. Esta escolha não se encaixa no eixo interpretação esperada, pois não evidencia alguma relação entre o fenômeno e a sua observação.

\section{Exemplo - Turma DELe}

$\mathrm{Na}$ figura 20 podem ser observadas as diferenças na diagramação entre a ficha utilizada em turmas brasileiras e as fichas utilizadas em turmas alemãs: 1) $\mathrm{Na}$ segunda afirmação, a palavra "animal selvagem" foi substituída por "leão" durante a tradução. 2) A escolha da alternativa não foi feita com o " $X$ " ao lado da alternativa, mas sim escrevendo a letra da respectiva alternativa na caixa presente logo abaixo. 3) O espaço para a justificativa é ligeiramente menor.

(tradução livre)

Unter einem klaren Himmel zu Mittag scheint die Sonne für jeden!

a) Es geschieht für jeden, weil die Sonne unabhängig von den Leuten scheint.

Com o céu aberto ao meio dia, o Sol brilha para todos!

a) Isso acontece para todos, pois o brilhar do Sol independe das pessoas.

Antwort $=\left[\begin{array}{l}a \\ a\end{array}\right]$

Resposta $=[a]$

Warum haben Sie so gewählt? Wa:! man sich jas and dem Hohs bravegsen hacem han

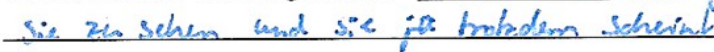

Por que fez essa escolha? Quando o sol brilha, brilha. É visivel para todos, mesmo para as pessoas na casa. Estes só precisam ir até a porta e já lhes brilha.

Figura 20 - Exemplo de resposta Conv\&Incoer etapa 1 - Turma DELe. (tradução nossa)

Tais modificações não foram consideradas relevantes durante a análise.

As justificativas que seguiram essa lógica são mais complicadas de serem categorizadas justamente porque revelam perspectivas e formas de escrever 
diferentes das esperadas. Por exemplo, nesta primeira etapa, o aluno escolhe a primeira alternativa. Sua justificativa inicia afirmando a característica independente do brilhar do Sol quando afirma que "Quando o sol brilha, brilha.", ou seja, brilharia de qualquer forma; isso indicaria o tipo 1 de explicação. Entretanto, continua sua justificativa relacionando o "brilhar" do Sol com a presença de pessoas, ou seja, utiliza o tipo de resposta 2. Nestes casos, consideramos que a resposta é incoerente por não se firmar entre os tipos preestabelecidos.

(tradução livre)

Ein Löwe wird mitten im Dschungel geboren. zu sehen und sie (die Sonne) ja trotzdem scheint.

a) Dies geschieht für jeden, auch wenn wir den Welpen nicht sehen.

Um leão nasce no meio da selva

a) Isso acontece para todos, mesmo que não vejamos o filhote.

Antwort $=[a$. $]$

Resposta $=[a]$

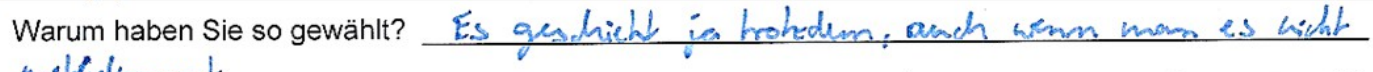
waibloliomanat

Por que fez essa escolha? Não sabemos da existência do recém-nascido, mas ele está lá e nós poderíamos vê-lo em teoria, se fossemos até ele.

Figura 21 - Exemplo de resposta Conv\&Incoer etapa 2 - Turma DELe

Na segunda etapa apresentada na figura 21, o trecho "mas ele está lá" indica que faz sentido para o aluno que o fenômeno "nascer" aconteça sem a observação de pessoas, ou seja, qualquer pessoa teria condições de ver, mas isso não é um condicionante para que o nascimento ocorra. Essa justificativa se aproxima do tipo 1.

Nestes casos, consideramos que a resposta é incoerente por que uma das etapas não se firmou entre os tipos preestabelecidos.

\section{Respostas divergentes e incoerentes (Div\&Incoer)}

Respostas divergentes e incoerentes são consideradas como as que fogem das linhas de raciocínio originalmente desenvolvidas para a questão. Considera-se que tais justificativas indicam uma percepção insuficiente do contexto apresentado, uma vez que ambas as alternativas divergem e, pelo menos uma é incoerente com o tipo adotado.

Essas respostas não são desejadas, mas vale ressaltar novamente que não 
existem respostas erradas, mas existem resposta fora do contexto desenvolvido para a questão. O tema, o contexto de classe e as tentativas de objetivação do instrumento talvez não tenham sido suficientes para sensibilizar os alunos que justificaram suas escolhas nesta categoria. Ou seja, a abordagem feita pode ter sida ineficiente e o aluno não se relacionou com a intenção original.

\section{Exemplo - Turma BR3A}

Com céu aberto ao meio dia, o Sol brilha para todos!

$(X)$ Isso acontece para todos, pois o brilhar do Sol independe das pessoas.

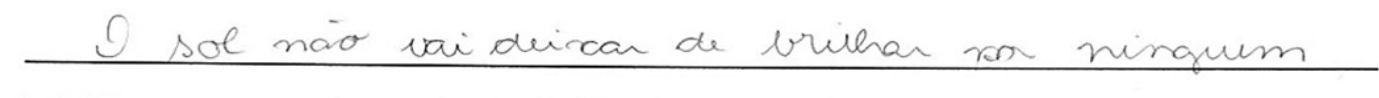

"O sol não vai deixar de brilhar pa ninguem"

Figura 22 - Exemplo de resposta Div\&Incoer etapa 1 - Turma BR3A

Na figura 22, a justificativa foi considerada muito superficial impossibilitando a interpretação para além do viés presente no ditado popular. Entretanto, com vistas na escolha alternativa e levando em conta uma leitura objetiva, poderíamos tratá-la como sendo do tipo 1.

Um animal nasce no meio de uma selva

(1) Isso acontece somente para o animal e sua mãe, pois ninguém mais sabe sobre o nascimento.

$\frac{\text { nià í do cont de ninguem, alem de mai is o }}{\text { animal navare }}$

"Não é da conta de ninguém, além da mãe se o animal nasceu"

Figura 23: Exemplo de resposta Div\&Incoer etapa 2 - Turma BR3A

A figura 23, a justificativa não tem coerência associada aos tipos, pois põe como núcleo a questão da privacidade no nascimento e não seu acontecimento quando afirma que "Não é da conta de ninguém (...)".

\section{Respostas descartadas}

Foram descartadas as respostas que possuíam algum dos quatro campos 
de preenchimento incompletos. No total foram descartadas 8 respostas restando um total efetivo de 100 respostas. Na tabela 1 é possível verificar as quantidades de respostas efetivas e descartadas por turma.

Tabela 1: Quantidade efetiva e descartada das respostas dadas à questão 3 da pesquisa auxiliar.

\begin{tabular}{ccc}
\hline Turma & Quantidade efetiva & Quantidade descartada \\
\hline BR3A & 26 & 3 \\
BR3E & 24 & 1 \\
BR2E & 18 & 3 \\
DEGr & 13 & 1 \\
DELe & 19 & 0 \\
Total & 100 & 8 \\
\hline
\end{tabular}

A tabela 2 abaixo apresenta as frequências em cada categoria e para cada turma e na figura 24 é possível observar o perfil da distribuição das categorias que formam a dimensão de continuidade.

Tabela 2: frequência nas categorias da dimensão de continuidade para cada turma.

\begin{tabular}{cccccc}
\hline & Conv\&Coer & Conv\&Incoer & Div\&Coer & Div\&Incoer & Total \\
\hline Turma BR3A & 9 & 4 & 6 & 7 & 26 \\
Turma BR3E & 10 & 2 & 4 & 8 & 24 \\
Turma BR2E & 5 & 4 & 3 & 6 & 18 \\
Turma DEGr & 3 & 3 & 6 & 1 & 13 \\
Turma DELe & 7 & 6 & 3 & 3 & 19 \\
Total & 34 & 19 & 22 & 25 & 100 \\
\hline
\end{tabular}

É possível observar uma expressiva semelhança entre os perfis das turmas brasileiras BR3A, BR3E e BR2E: a predominância das respostas Conv\&Coer e Div\&Incoer em relação às outras duas categorias. Em especial, a distribuição da turma BR3E aparentemente indica que a instância de alunos, aqui no Brasil, possuía duas linhas de raciocínio significativas antes do início da sequência didática: alunos que convergiam para o contexto esperado no questionamento e justificavam de forma coerente suas escolhas em contraposição ao grupo dos que divergiam sobre a forma de encarar o "acontecimento" e ainda apresentavam pelo menos uma 
justificativa incoerente.

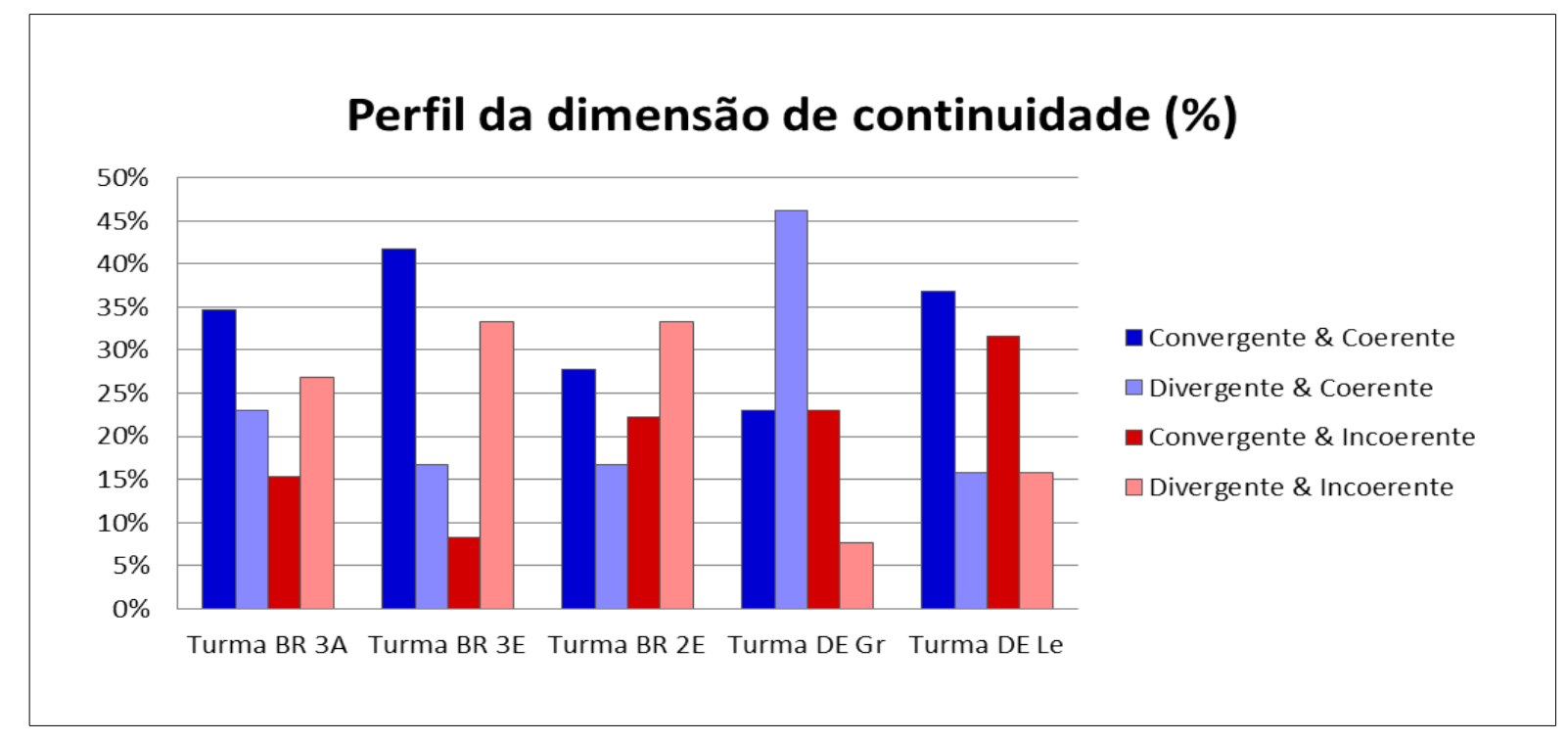

Figura 24 - Perfil da distribuição de respostas para a dimensão de continuidade.

As turmas DEGr e DELe, por sua vez possuem um perfil completamente diferente mesmo sendo entre elas da mesma cidade. A DEGr possui um grupo de respostas Div\&Coer que compreende quase metade das respostas dadas. Esse grupo é flanqueado pelos grupos convergentes. Menos de $10 \%$ das respostas foram categorizadas como Div\&Incoer. A turma DELe tem um perfil misto contando com aproximadamente $70 \%$ das respostas nas duas categorias de convergência.

Vale apontar que as respostas Div\&Incoer são consideradas problemáticas porque refletiriam percepção insuficiente. A frequência destas respostas é expressiva em todas as turmas brasileiras e bem menor nas turmas alemãs.

Uma hipótese possível para se compreender esse comportamento está associado ao fato de que os dois professores das turmas brasileiras participaram de todo o desenvolvimento e aplicação do projeto. Isso poderia fazer pensar que estes perfis refletissem uma postura adquirida ao longo dos meses de trabalhos anteriores. Entretanto essa explicação é pouco provável tendo em vista que os alunos das turmas BR3A, BR3E (professor A) e BR2E (professor D) tiveram conteúdos distintos típicos de turmas do $3^{\circ}$ e $2^{\circ}$ anos do Ensino Médio respectivamente. Existe também uma grande diferença notada entre os dois professores. Por exemplo, o professor A (BR3A e BR3E) possui larga experiência em sala de aula, uma característica mais introspectiva e maior adesão às ideias 
desenvolvidas nas reuniões. Já o professor D (BR2E) é mais jovem na carreira apresentando maior tendência a construir suas aulas com ideias próprias adaptadas às da coletividade do grupo. Nessa explicação, as turmas DEGr e DELe teriam um perfil diferente devido ao não contato com a sequência durante seu processo de desenvolvimento. Cada turma refletiria a postura de seu respectivo professor independentemente.

Entretanto existe outra hipótese a qual atribuímos maior credibilidade com base principalmente nas observações diretas das aulas. Todas as turmas eram muito diferentes entre si, assim como cada um dos quatro professores. A melhor explicação para um perfil tão parecido nas turmas brasileiras e tão diferente nas turmas alemãs deveria estar em algo que fosse comum às brasileiras, mas que fosse diferente nas alemãs. Assim, talvez o perfil esteja associado mais ao currículo escolar do que aos professores ou alunos. Não a dimensão curricular relacionada ao conteúdo em si, mas àquela associada à forma como os alunos estudam tais conteúdos durante o Ensino Médio.

Nessa hipótese, o perfil na figura 24 representaria 3 currículos distintos. 0 primeiro currículo enquadraria as turmas brasileiras cujo perfil aponta dois grupos majoritários Conv\&Coer e Div\&Incoer. No caso nacional, o currículo tem a finalidade de desenvolver basicamente atributos de cidadania para a realidade social e cultural do Brasil. O segundo currículo é o da turma DEGr que tem como finalidade uma educação propedêutica voltada às Ciências Humanas. Há um expressivo grupo Div\&Coer podendo indicar o resultado de uma formação mais sensível às particularidades do próprio texto e levando em consideração contextos diversos fora do científico sem perder coerência na escolha feita. Nessa direção, chama a atenção a pequena quantidade de respostas Div\&Incoer desta turma. O terceiro currículo é o da turma DELe que também possui caráter propedêutico, mas voltado para a área de Ciências Naturais. As respostas da DELe mostram um grande número de convergentes se contabilizadas de forma única as respostas incoerentes e coerentes. Essa característica mostraria uma percepção mais desenvolvida no que diz respeito ao tipo de pensamento normalmente associado a Ciências físicas, ou seja, essas respostas indicariam um grande grupo que reconhece o que se espera normalmente em ensino de ciências, mesmo que suas justificativas não sejam coerentes. 


\section{Análise de alinhamento}

A análise de alinhamento tem como finalidade apresentar como as diferentes turmas que participaram do projeto se alinhavam inicialmente a uma das ideias importantes presentes em relatividade: a noção de acontecimento ou evento. $\mathrm{Na}$ figura 25 é possível observar o perfil de cada turma.

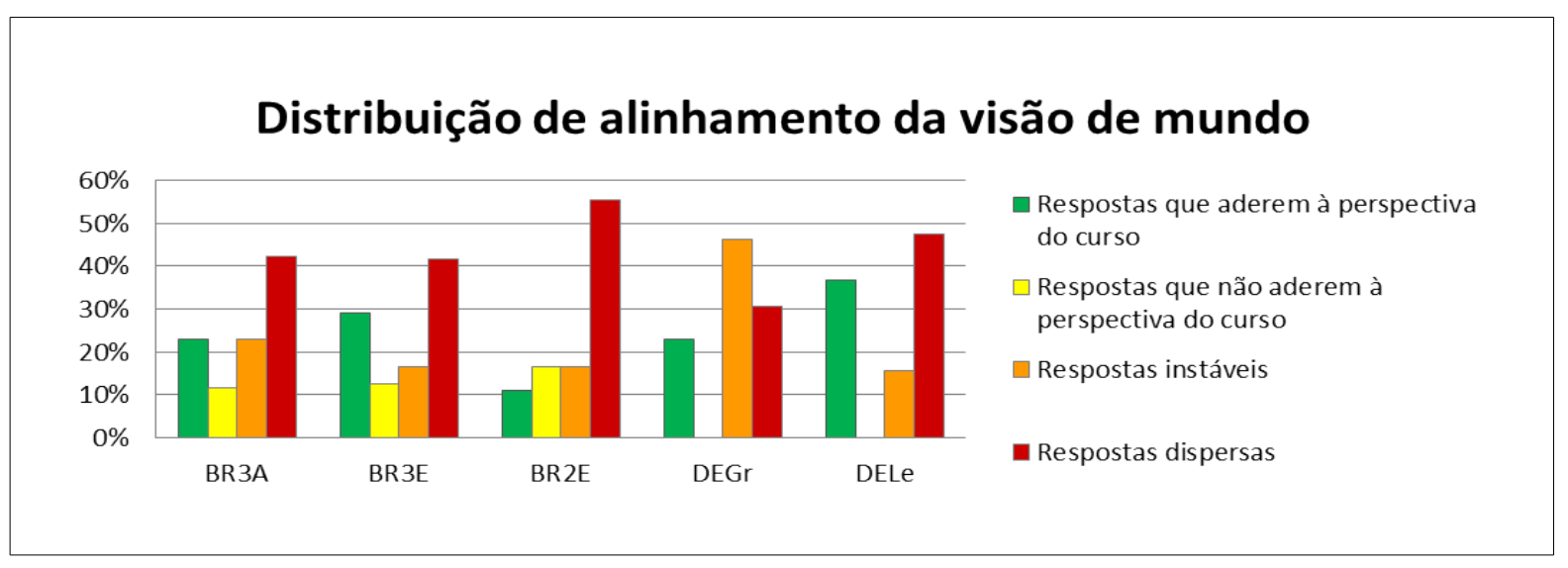

Figura 25 - Distribuição de respostas para a dimensão de alinhamento.

Quando se observa a figura 25, o primeiro resultado que chama a atenção é a grande quantidade de respostas dispersas em todas as turmas, ou seja, a proporção de alunos que responderam de forma incoerente. Essa proporção indica que é necessário atenção extra para a forma de se expressar dos alunos no próximo desenho da sequência, pois em torno de $40 \%$ justificou sua resposta de forma insuficiente ou de forma confusa com relação ao que era esperado.

A turma BR2E foi, por um lado, a que mais apresentou grande número de respostas dispersas contando com mais da metade de todas nessa categoria. Por outro lado, ela foi a que menos possuiu respostas que aderem à perspectiva da sequência. É difícil explicar um perfil tão distante do esperado: é possível esse comportamento esteja associado à imaturidade acadêmica dos alunos que ainda estavam no $2^{\circ}$ ano do Ensino Médio; ou que possa estar associado mais à forma de trabalho do professor tendo em vista a semelhança das outras duas turmas brasileiras as quais possuem o mesmo professor. Entretanto ambas as explicações são especulativas.

A turma BR3A possui $23 \%$ das respostas aderindo à perspectiva do curso, já a BR3E apresenta 29\%. Ambas as turmas BR3A e BR3E possuem um perfil semelhante para as respostas dispersas e respostas que não aderem à sequência 
em proporções praticamente iguais, $42 \%$ e $12 \%$ respectivamente. Esse comportamento de forma geral semelhante apresentado pelas duas turmas parece reforçar a hipótese de que haja uma relação entre o professor e o perfil de alinhamento da turma, mas ainda há a hipótese de que seja o simples despreparo típico da etapa de aprendizado dos alunos.

Algo realmente interessante é o fato de ambas as turmas alemãs não possuírem sequer uma resposta não aderente à sequência didática. Não há uma resposta Coer\&Conv com a explicação do tipo 2, ou seja, de algum modo os alunos alemães sabem qual contexto não é esperado, ainda que sua resposta seja instável ou dispersa.

A turma DELe chama a atenção quanto à existência de dois grupos bem distintos. O grupo dos que aderem à perspectiva da sequência é a maior porcentagem em relação a todas as turmas. Esse comportamento é esperado tendo em vista o currículo científico praticado pela turma o qual certamente já apresenta constantemente um direcionamento no tratamento deste tipo de questão. Já o grande grupo de respostas dispersas mostra uma parcela significativa da sala com dificuldades em convergir sua resposta.

A turma DEGr por sua vez possui uma grande proporção de respostas instáveis, ou seja, aquelas em que as escolhas são divergentes e as explicações dadas são coerentes com as escolhas. Essa turma teve uma participação expressiva de respostas que aderem à perspectiva da sequência e a menor proporção de respostas dispersas.

Tendo em mãos os perfis tanto da dimensão de continuidade quanto da dimensão de alinhamento, fica mais fácil propor medidas a serem desenvolvidas no próximo ciclo da sequência de RR. Como a finalidade deste estudo está vinculado ao contexto nacional, toma-se as turmas brasileiras como referência comportamental. As informações das turmas alemãs são consideradas adicionais ou optativas.

Algo que se deve levar em conta nos próximos ciclos é a existência de aproximadamente $1 / 3$ de alunos brasileiros que não conseguem manter um mesmo raciocínio entre duas afirmações de mesma qualidade quando os contextos são distintos trazendo justificativas incoerentes com o esperado (Div\&Incoer). Esse significativo grupo não poderá constituir surpresa para o professor devendo esta 
informação ser apresentada no material do professor. Uma sugestão inicial seria o desenvolvimento das atividades em grupo visando a interatividade entre a parcela de alunos Conv\&Coer e a parcela Div\&Incoer para promover troca de experiências que ajudasse a parcela Div\&Incoer a um posicionamento favorável a compreensão do conteúdo apresentado.

Se for considerado o grupo de respostas dispersas, a proporção dos alunos chega a aproximadamente $40 \%$. Para esses que possuem suas justificativas incoerentes, talvez fosse possível trabalhar esse aspecto na primeira atividade tendo em vista sua característica de introduzir sobre qual "tipo" de tempo será tratado na sequência. Essa discussão pode ser estendida ou modulada para tratar não só do tempo, mas também dos acontecimentos como algo objetivo e mensurável.

Quando se adota a hipótese de que o principal elemento definidor dos perfis é a associação do tipo de currículo com a visão promovida pela sequência, é possível verificar que a melhor relação se encontra nas turmas alemãs justamente por não possuírem respostas que coerentemente vão contra a sequência didática. Essa ideia leva a pensar sobre os motivos do desempenho estrangeiro ser melhor do que o desempenho nacional na pesquisa auxiliar.

Nesta direção talvez seja interessante incluir transversalmente na sequência elementos e discussões que promovam o desenvolvimento do espírito científico no aluno. Um momento específico para se tratar isso seria a atividade 3 onde são discutidas as perspectivas de Newton e Einstein para o conceito de absoluto e relativo.

\subsection{ANÁLISE DO FLUXO}

A análise do fluxo foi construída principalmente a partir da organização dos dados nas dimensões de interface e fluência. O instrumento de fluxo foi aplicado nas turmas BR2E, BR3A e BR3E. 


\subsubsection{Exemplos e Análise da Dimensão de Interface}

A Dimensão de Interface é dividida em duas categorias que comportam quais respostas estão próximas da moral da história (AproxMH) e quais não estão (AfastMH). Ambas as categorias foram definidas no tópico 4.4 Instrumento de fluxo página 91 , mas nenhum dos parâmetros relacionados às atividades foi exemplificado para não criar uma quebra na leitura e reunir todo o movimento de análise da pesquisa em uma única seção.

Ao final da apresentação de cada categorização foi disponibilizada as contagens feitas para as respectivas categorias e um perfil comparativo das frequências das categorias AproxMH e AfastMH. A ideia foi familiarizar o leitor com os resultados que serão discutidos posteriormente.

\subsubsection{Interface para a Atividade 1}

A atividade 1 não possui subcategorias além da $\operatorname{AproxMH}(a)^{26}$.

AproxMH(a) Atv1: reúne as respostas que apontam o tempo físico como o de maior pertinência quando se está tratando de fenômenos relativísticos.

\subsubsection{Interface para a Atividade 2}

AproxMH(a) Atv2: Agrupa as respostas nas quais o fenômeno ocorre a todo momento mesmo que não percebamos sua influência no cotidiano [\&] o fenômeno é imperceptível em condições físicas onde as velocidades são baixas. Há generalização do fenômeno para além das condições específicas ou percepção. 


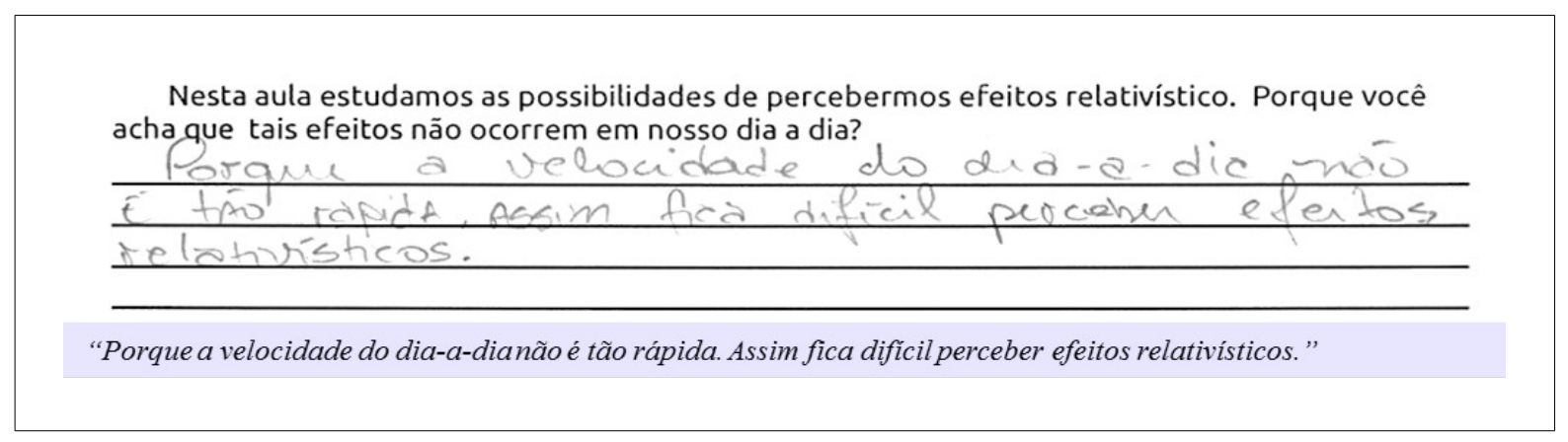

Figura 26 - Exemplar AproxMH(a) - Dimensão de Interface - Atv 2, turma BR3A - ficha 47:7.

No exemplar da figura 26 é possível observar que a dificuldade em se perceber os efeitos relativísticos se dá devido às baixas velocidades presentes no dia a dia, ou seja, não há indícios de que o aluno considere que o fenômeno só ocorra em situações especiais. Desta forma, o aluno generaliza o fenômeno e distingue sua existência de sua percepção.

AproxMH(b) Atv2: agrupa as respostas que indicam que o fenômeno ocorre relacionado com a velocidade, mas limitam-se aos contornos do problema apresentado na atividade ou omitem a existência do fenômeno em baixas velocidades. Não há generalização e a existência do fenômeno é considerada limitada a condições específicas.

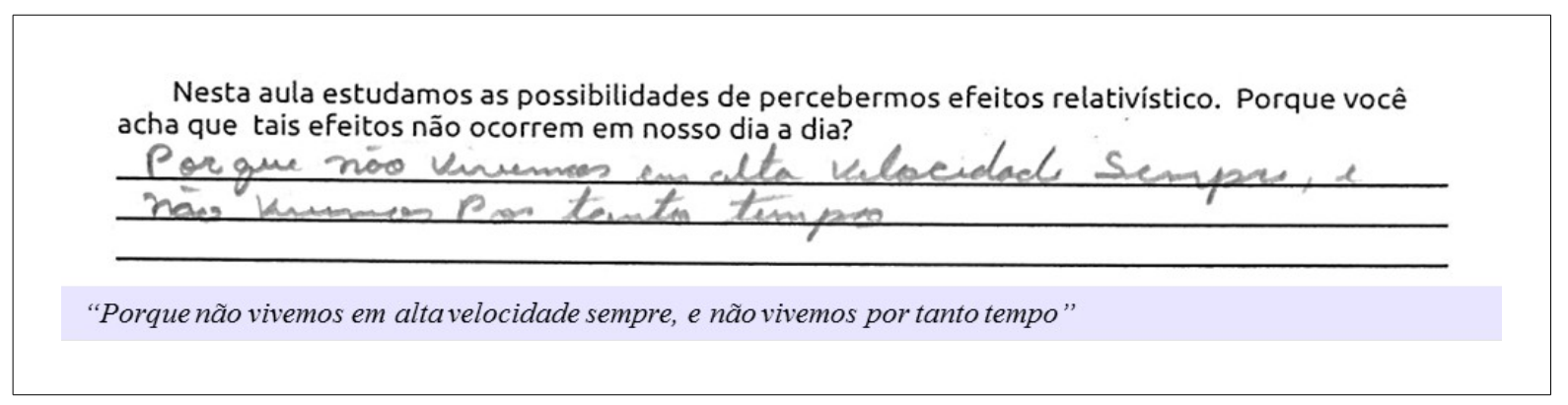

Figura 27 - Exemplar AproxMH(b) - Dimensão de Interface, - Atv 2, turma BR2E - ficha 73:6.

A figura 27 exemplifica um caso recorrente durante a análise. $O$ aluno não deixa claro se considera a existência do fenômeno da diferenciação do tempo em baixas velocidades. Soma-se a isso o aparente tendência de associar sua resposta ao problema proposto no material do aluno na atividade 2. Respostas deste tipo, quando observadas em conjunto, indicam a existência de uma subcategoria em que 
o aluno não generaliza o fenômeno da diferenciação do tempo para além da situação específica de alta velocidade.

AfastMH Atv2: reúne as respostas insuficientes ou distantes da moral da história.

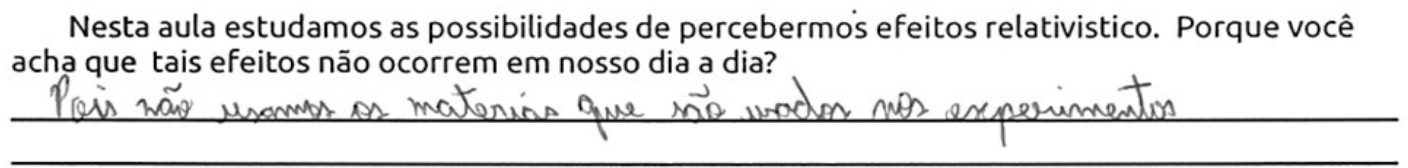

"Pois não usamos os materiais que não são usados nos experimentos"

Figura 28 - Exemplar da AfastMH - Dimensão de Interface - Atv 2, turma BR3E - ficha 48:3.

Nesta categoria surgiram respostas diversas que fogem da moral da história proposta. Há maior frequência daquelas em que o aluno afirma que os efeitos ocorrem, mas não são percebidos. Tais respostas não convergem para a moral da história e objetivos da atividade. No exemplar da figura 28 , o aluno não faz referência à dependência da velocidade para a existência do fenômeno. Parece compreender que o fenômeno da diferenciação não existe naturalmente e seria produzido por equipamentos especiais ${ }^{27}$. Outra interpretação aponta a crença na existência de elementos ou materiais que proveriam algum tipo de característica relativística às situações.

Quando se observou as respostas para o instrumento de fluxo entregue na atividade 2, algumas interpretações não esperadas apareceram. A questão é feita da seguinte forma: "Nesta aula estudamos as possibilidades de percebermos efeitos relativísticos. Porque você acha que tais efeitos não ocorrem em nosso dia a dia?". Sete (7) respostas AfastMH da BR3E apresentaram algo parecido a um ataque à afirmação feita no corpo da questão em detrimento da resposta esperada. Num dos casos uma aluna escreveu: "Efeitos relativísticos ocorrem sim em nosso dia a dia." (Aluna da BR3E, ficha 48:18). Em outro: "Está falando que não ocorre, mais isso no dia a dia ocorre sim." (Aluno da BR3E, ficha 48:19)

A intenção na última frase da questão era separar o mundo visível do invisível, ou seja, o termo "dia a dia" foi pensado como sendo a parte do mundo

27 Vale observar que o pesquisador se posiciona filosoficamente tomando a existência dos fenômenos físicos na natureza como independentes do emprego da técnica para reproduzi-los. 
físico perceptível pelos sentidos. Entretanto 5 respostas indicam uma interpretação diversa da questão. Duas hipóteses surgem: ou alguns alunos consideram elementos não perceptíveis pelos sentidos como parte cotidiano (um modo emancipado de percepção); ou esse comportamento foi induzido pelo professor, o que é provável porque somente respostas de uma turma apresentaram esse resultado. De qualquer forma, esse tipo de resposta sinaliza a necessidade de tornar a pergunta mais clara. Uma sugestão é: "Porque você acha que tais efeitos são imperceptíveis em nosso dia a dia?".

Abaixo segue o quadro 21 com a distribuição de respostas para as subcategorias de interface e um histograma com as frequências da dimensão de interface da atividade 2.

\begin{tabular}{|c|c|c|c|c|c|c|c|}
\hline \multicolumn{5}{|c|}{ Atividade 2 - Frequências para a Dimensão de Interface } & \multicolumn{3}{|c|}{ ATV2 - D. Interface } \\
\hline & BR3A & BR3E & BR2E & TOTAL: & \multirow{2}{*}{$5^{13}$} & \multirow{2}{*}{5} & \multirow{2}{*}{$7^{16}$} \\
\hline AproxMH(a) Atv2 & 4 & 0 & 1 & 5 & & & \\
\hline AproxMH(b) Atv2 & 1 & 5 & 6 & 12 & $n$ & $n$ & \\
\hline AfastMH Atv2 & 13 & 19 & 16 & 48 & BR3A & BR3E & $\mathrm{BR} 2 \mathrm{E}$ \\
\hline Branc/Incorr Atv2 & 8 & 3 & 0 & 11 & \multirow{2}{*}{\multicolumn{3}{|c|}{ AproxMH $\square$ AfastMH }} \\
\hline TOTAL & 26 & 27 & 23 & 76 & & & \\
\hline
\end{tabular}

Quadro 21: Distribuição de respostas para subcategorias de interface e histograma da Atividade 2. O perfil apresentado ao lado da tabela não computa as respostas da categoria Branc/lncorr.

\subsubsection{Interface para a Atividade 3}

AproxMH(a) Atv3: compreende as respostas que explicam a palavra "relativo" como algo dependente de outra coisa com base nas ideias de Einstein e Newton apresentadas na atividade 3. O conceito de evento ou a velocidade da luz são os elementos não relativos esperados.

A resposta presente na figura 29 não deixa claro se o aluno compreendeu corretamente a segunda parte da pergunta, é possível que ele tenha confundido a questão original pela: "o que é relativo segundo a perspectiva de Einstein?" Entretanto, a resposta mostra uma definição clara para o que é e o que não é relativo quando afirma que "a luz tem velocidade independente do estado de movimento" e quando afirma que relativo é aquilo "diferente de acordo com a 


\section{situação de movimento".}

Houve apenas mais uma resposta nessa categoria, nela o aluno aponta que o tempo como relativo e a velocidade da luz como absoluta.

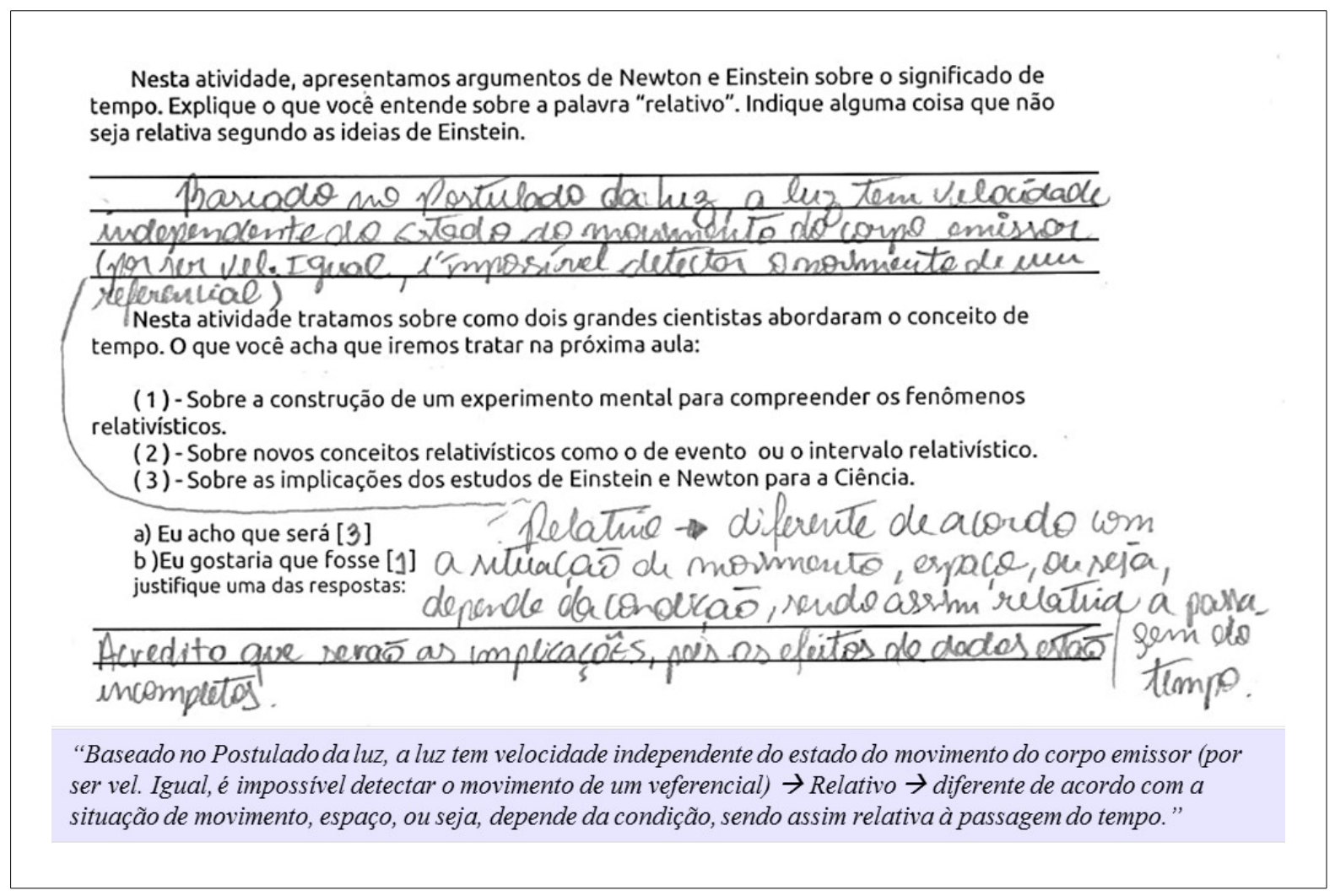

Figura 29 - Exemplar AproxMH(a) - Dimensão de Interface - Atv 3, turma BR3E - ficha 52:1.

\section{AproxMH(b1) Atv3: reúne as respostas que consideram a palavra "relativo"} como uma relação ou dependência com outra coisa de forma generalizada.

Nesta atividade, apresentamos argumentos de Newton e Einstein sobre o significado de tempo. Explique o que você entende sobre a palavra "relativo". Indique alguma coisa que não seja relativa segundo as ideias de Einstein.

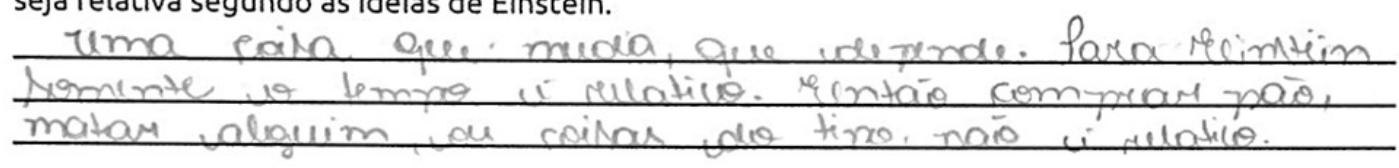

"uma coisa que muda, que depende. Para Einstein somente o tempo é relativo. Então comprar pão, matar alguém, ou coisas do tipo, não é relativo."

Figura 30 - Exemplar AproxMH(b1) - Dimensão de Interface - Atv 3, turma BR2E - ficha 74:1. 
O exemplar na figura 30 converge para a moral da história entretanto não há indicação de que a palavra "relativo" foi tomada de forma específica ao caso da relatividade. Quando o aluno escreve “uma coisa que muda, que depende", não deixa claro nem a mudança e nem a dependência a que se refere. Na frase seguinte restringe as ideias einsteinianas à passagem do tempo. Os elementos não relativos citados são bons exemplos de eventos.

As diversas respostas feitas nessa direção parecem indicar uma transformação do argumento vago para algo mais objetivo.

AproxMH(b2) Atv3: compreende as respostas que restringem a palavra "relativo" ao conceito de tempo.

\footnotetext{
Nesta atividade, apresentamos argumentos de Newton e Einstein sobre o significado de tempo. Explique o que você entende sobre a palavra "relativo". Indique alguma coisa que não seja relativa segundo as ideias de Einstein.

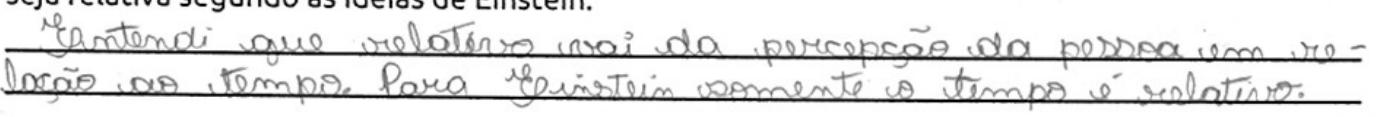

"Entendi que relativo vai da percepção da pessoa em relação ao tempo. Para Einstein somente o tempo é relativo.
}

Figura 31 - Exemplar AproxMH(b2) - Dimensão de Interface - Atv 3, turma BR2E - ficha 74:12.

A primeira frase da resposta na figura 31, está conforme esperado, tendo em vista que não fora apresentado até aquele momento o termo "referencial". A segunda frase da resposta associa a palavra "relativo" estritamente ao conceito de tempo, ignorando outros conceitos e não deixando claro sobre o que seria absoluto em relatividade.

Tanto a resposta da figura 31 quanto a da figura 30, e outras mais, advindas da turma BR2E apresentaram algo aproximado da expressão "somente o tempo é relativo". Esse termo não aparece no material, mas foi utilizado pelo professor de forma auxiliar para atacar a afirmação de que "tudo é relativo para Einstein". Aparentemente, os alunos compreenderam essa afirmação de forma inesperada. Essa expressão encerra um detalhe crítico a ser observado nos próximos ciclos.

AfastMH Atv3: agrupa as respostas insuficientes ou distantes da moral da história. 
A resposta na figura 32 indica uma definição vaga para a palavra "relativo" porque não aponta, na primeira frase, elementos que remetam à relatividade. A afirmação de que tudo é relativo rebaixa diretamente a resposta para a categoria AfastMH tendo em vista a centralidade desta abordagem na moral da história. A segunda frase indica uma relação aparentemente gradativa entre ser relativo ou invariante se afastando das definições propostas pela sequência.

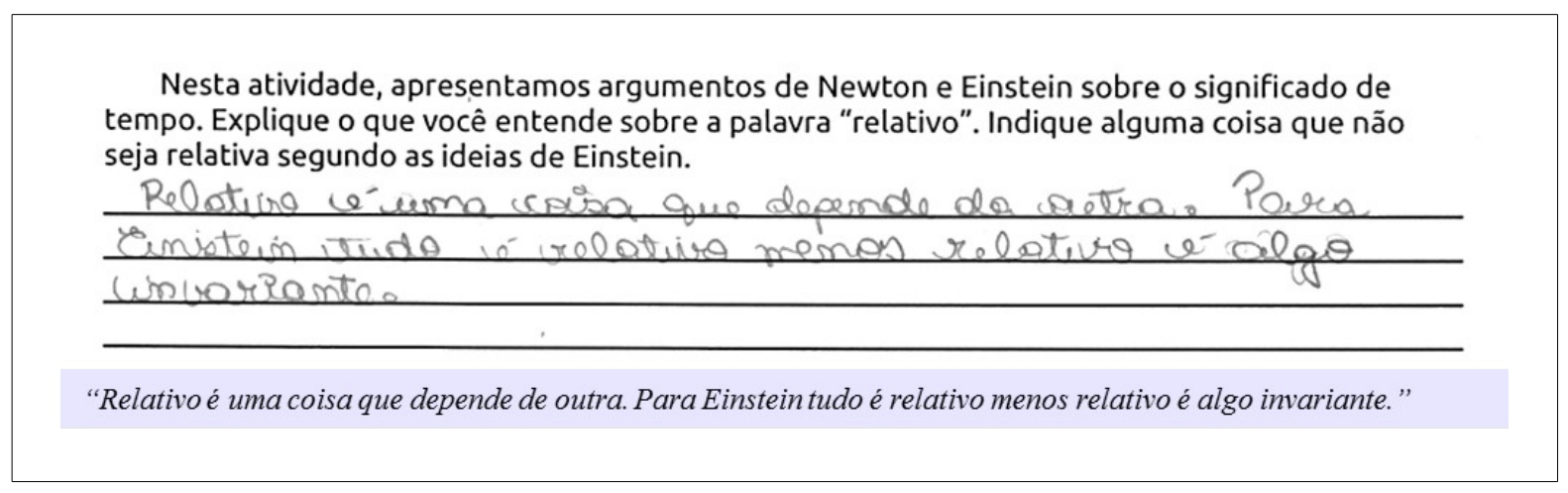

Figura 32 - Exemplar AfastMH - Dimensão de Interface - Atv 3, turma BR3E - ficha 50:8.

Vários alunos tiveram dificuldade em compreender a frase final presente no instrumento de fluxo da atividade 3: "Indique alguma coisa que não seja relativa segundo as ideias de Einstein." Em várias respostas foi possível verificar uma confusão entre as palavras relativo, relativístico e relatividade. Por exemplo: "Relativo é a velocidade da luz e nada pode alcançar esta velocidade. (aluno $B R 3 A)$ ). Nessa resposta, o aluno utiliza a palavra "relativo" ao invés de "relativística". O uso desatento dessa terminologia pode configurar um detalhe crítico a ser atacado nas atividades. Uma alternativa é diminuir o número de termos e simplificar os jargões utilizados no material dos alunos e professores.

Com relação a essa mesma pergunta, surgiu um tipo de resposta que aponta uma confusão na compreensão sobre o que seria "relativo para Einstein". Na resposta exemplar "Bom, na ideia de Einstein, unica coisa que é relativo é o tempo, ou seja, unica coisa que muda é o tempo. Somente a velocidade da luz que é absoluta." (Aluno, BR2E, ficha 74:22), o aluno especifica bem a resposta utilizando palavras como "única" e "somente". A resposta é coerente para o desenvolvimento dos conceitos naquele momento e foi categorizada como $\operatorname{Aprox} \mathrm{MH}(\mathrm{A})$, mas inclui a ideia de que o tempo é a única coisa relativa.

Aparentemente esse tipo de resposta está associado a uma composição 
ruim de explicações. A atividade 3 tem objetivo de afirmar que "nem tudo é relativo na relatividade". Entretanto ela também afirma que "para Einstein o tempo é relativo". Como os alunos não possuíam outros exemplos de conceitos relativos, alguns acabaram por compreender equivocadamente que apenas o tempo é relativo para Einstein.

Abaixo segue o quadro 22 com a distribuição de respostas para as subcategorias de interface e um histograma com as frequências da dimensão de interface da atividade 3.

\begin{tabular}{|c|c|c|c|c|c|c|c|}
\hline \multicolumn{5}{|c|}{ Atividade 3 - Frequências para a Dimensão de Interface } & \multirow{2}{*}{\multicolumn{3}{|c|}{ ATV3 - D. Interface }} \\
\hline & BR3A & BR3E & BR2E & TOTAL: & & & \\
\hline AproxMH(a) Atv3 & 0 & 1 & 1 & 2 & \multirow{2}{*}{$4^{7}$} & \multirow[b]{2}{*}{46} & 1212 \\
\hline AproxMH(b1) Atv3 & 3 & 3 & 5 & 11 & & & \\
\hline AproxMH(b2) Atv3 & 1 & 0 & 6 & 7 & a & a & \\
\hline AfastMH Atv3 & 7 & 6 & 12 & 24 & BR3A & BR3E & BR2E \\
\hline Branc/Incorr Atv3 & 4 & 2 & 2 & 8 & & & \\
\hline TOTAL & 15 & 12 & 26 & 52 & & & \\
\hline
\end{tabular}

Quadro 22: Distribuição de respostas para subcategorias de interface e histograma da Atividade 3. O perfil apresentado ao lado da tabela não computa as respostas da categoria Branc/lncorr.

\subsubsection{Interface para a Atividade 4}

AproxMH(a) Atv4: compreende as respostas onde a constância da velocidade da luz está relacionada a pontos de vista ou referenciais. A constância da velocidade da luz não deve se associar à constância clássica de velocidade.

Algumas respostas foram feitas em folhas de caderno, como pode ser visto abaixo. Para simplificar a leitura, segue reproduzida a questão da atividade 4, presente no quadro 14: "Durante a aula utilizamos a luz para compreender a diferenciação do tempo. O que significa dizer que a luz possui velocidade constante para você?" 


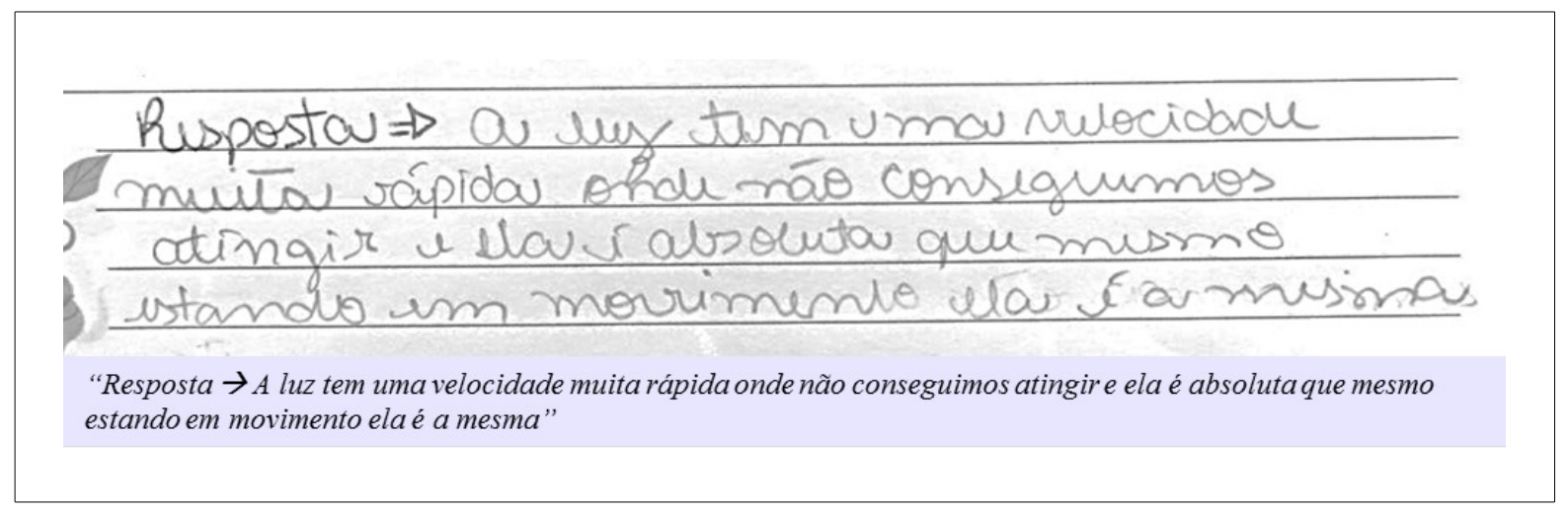

Figura 33 - Exemplar AproxMH(a) - Dimensão de Interface, - Atv 4, turma BR2E - ficha 75:1.

Ainda que tenha havido dificuldades típicas ao aluno em processo de aprendizagem, no que diz respeito à eleição dos elementos que compõem a frase, a resposta indica compreensão do caráter absoluto da velocidade da luz conforme o esperado.

Das 5 respostas desta subcategoria 4 são da turma BR2E. Todas as respostas indicam compreensão parecida ou melhor do que o exemplar.

AproxMH(b) Atv4: essa subcategoria agrupa as repostas em que a velocidade da luz é considerada sempre constante, mas sem conexão explícita com a noção de mudança de referenciais.

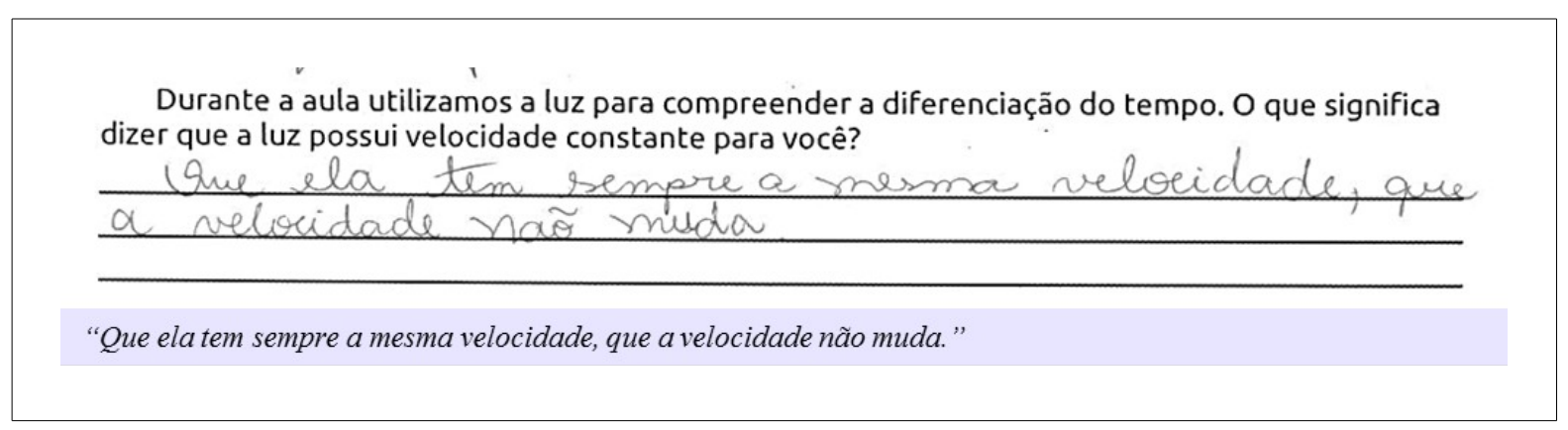

Figura 34 - Exemplar AproxMH(b) - Dimensão de Interface, - Atv 4, turma BR3A - ficha 53:2.

É difícil ter certeza se a luz é considerada com velocidade constante para qualquer meio ou por mudança de referencial. Para a primeira possibilidade, seria a luz constante em seu movimento, mas possível de ser ultrapassada, assim como um objeto clássico em movimento. Já para a segunda possibilidade, a constância seria associada à impossibilidade de mudança de velocidade mesmo quando 0 
observador muda de referencial. Esta categoria de respostas foi difícil de ser estabilizada porque encerra uma incerteza sobre a compreensão de vários alunos.

Com base nas falas em classe e a inexistência do contexto relacionado à velocidade no meio, tomou-se a posição de considerar tais respostas como aproximadas da moral da história. Isso porque foi comum, pelo menos na turma BR2E durante a atividade 4, o uso de expressões como "a luz tem a mesma velocidade sempre" como sinônimo de possuir a mesma velocidade tanto para quem está no chão quanto para quem está sobre o skate.

AfastMH Atv4: esta subcategoria reúne as respostas insuficientes ou distantes da moral da história.

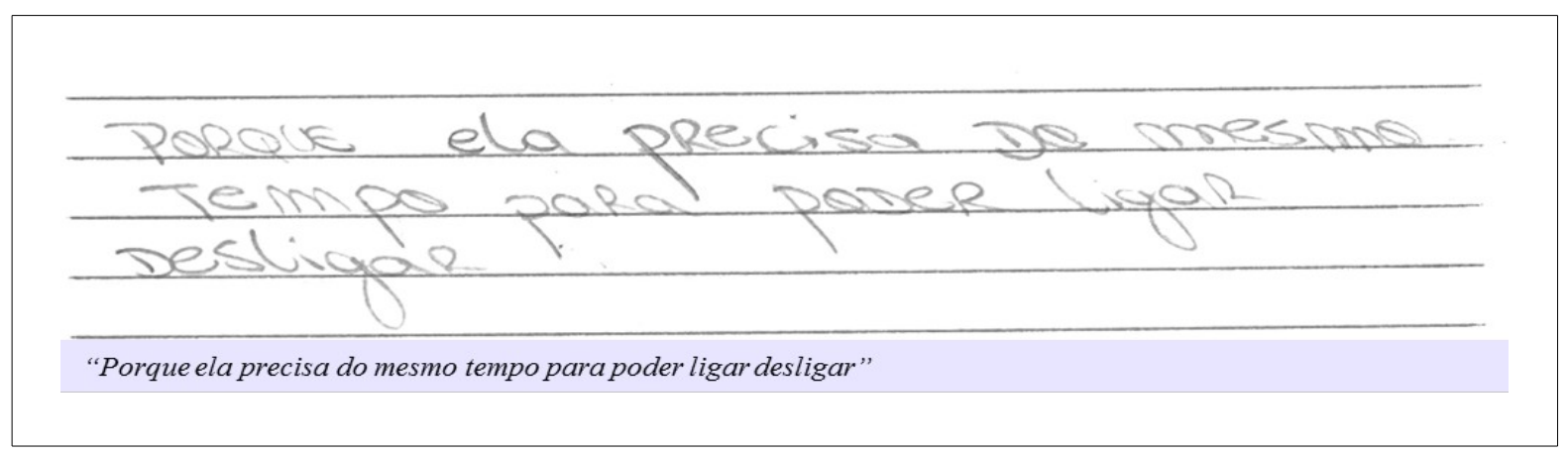

Figura 35 - Exemplar AfastMH - Dimensão de Interface - Atv 4, turma BR2E - ficha 75:27.

A resposta presente na figura 35 está relacionada ao experimento de pensamento R-Luz presente na atividade 4. O aluno parece considerar a constância da velocidade da luz como algo restrito ao experimento, destinado a fazê-lo funcionar ou algo similar. Não há indicação da emancipação dos conceitos para situações além do proposto.

As demais respostas se abrem num leque difuso de tentativas: "Que tem (possui) luz própria." (aluno, BR3A) ou "Poque estamos em constante movimento" (aluno, BR3E).

Abaixo segue o quadro 23 com a distribuição de respostas para as subcategorias de interface e um histograma com as frequências da dimensão de interface da atividade 4. 


\begin{tabular}{|c|c|c|c|c|c|c|c|}
\hline \multicolumn{5}{|c|}{ Atividade 4 - Frequências para a Dimensão de Interface } & \multirow{2}{*}{\multicolumn{3}{|c|}{ ATV4 - D. Interface }} \\
\hline & BR3A & BR3E & BR2E & TOTAL: & & & \\
\hline AproxMH(a) Atv4 & 0 & 1 & 5 & 6 & $1_{5}$ & $10_{3}$ & 7 \\
\hline AproxMH(b) Atv4 & 11 & 9 & 15 & 35 & n & $\omega^{3}$ & $n$ \\
\hline AfastMH Atv4 & 5 & 3 & 7 & 15 & BR3A & BR3E & BR2E \\
\hline Branc/Incorr Atv4 & 3 & 3 & 0 & 6 & & & \\
\hline TOTAL & 19 & 16 & 27 & 62 & & & \\
\hline
\end{tabular}

Quadro 23: Distribuição de respostas para subcategorias de interface e histograma da Atividade 4. O perfil apresentado ao lado da tabela não computa as respostas da categoria Branc/Incorr.

\subsubsection{Interface para a Atividade 5}

É importante sinalizar que existe uma incoerência entre a Questão e a moral da história no instrumento de fluxo da Atividade 5. A questão aponta especificamente para o conceito de referencial próprio enquanto o fluxo aponta para a constância da velocidade da luz e o não solucionamento do problema dos gêmeos. De fato a questão foi equivocada, pois o conceito de referencial próprio não é abordado sistematicamente nas atividades. Este problema de fidedignidade do instrumento neutraliza, as conclusões criadas sobre o fluxo da atividade 5 porque, a princípio, as respostas dos alunos não estariam vinculadas diretamente ao fluxo da atividade.

Entretanto, ainda que descompassadas com o fluxo, as respostas trazem informações sobre o avanço que os alunos tiveram na atividade. Para aproveitar estas informações, optou-se por flexibilizar o critério original no desenvolvimento da subcategoria $\operatorname{AproxMH}(b)^{*}$ e da categoria AfastMH $^{*}$ para que abrangessem a realidade dos dados e permitissem torná-los artificialmente suficientes para a cruzamento que será feito com os dados da $2^{\mathrm{a}}$ etapa do instrumento de fluxo. Essas considerações impactam somente nos dados da atividade 5 e serão indicadas oportunamente ao leitor. ${ }^{28}$

AproxMH(a) Atv5: reúne as respostas que consideram o referencial próprio como aquele onde os eventos importantes ocorrem no mesmo lugar. 
Nenhuma resposta se enquadrou nessa subcategoria.

$\operatorname{Aprox} \mathbf{M H}(\mathbf{b 1})^{*}$ Atv5: agrupa as respostas que associam o referencial próprio mais como um conteúdo procedimental da atividade 5 do que como um conteúdo conceitual. Neste grupo estão aplicados os critérios de flexibilização da atividade 5.

Nesta aula estudamos alguns detalhes importantes relacionado ao entendimento da relatividade. Qual é o significado do termo "referencial próprio" para você?

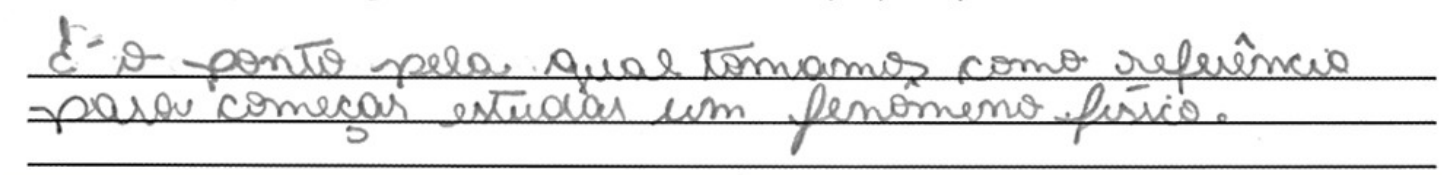

"É o ponto pela qual tomamos como referência para começar estudar um fenômeno físico."

Figura 36 - Exemplar AproxMH(b1)* - Dimensão de Interface - Atv 5, turma BR3A - ficha 57:6.

$\mathrm{Na}$ figura 36, a resposta apresenta a definição de referencial próprio diretamente associada à forma de resolução tipicamente utilizada em problemas relativísticos. Esse comportamento pode ser explicado pela ênfase que esta atividade dá aos conteúdos procedimentais. Respostas assim foram encontradas em todas as turmas de forma homogênea: "É o referencial de cada um diante do objeto." (aluno, BR2E).

$\operatorname{Aprox} M H(b 2)^{*}$ Atv5: reúne as explicações mais difusas sobre o que é um referencial. Nesta subcategoria há maior enfoque no caráter conceitual. Estão aplicados os critérios de flexibilização da atividade 5 .

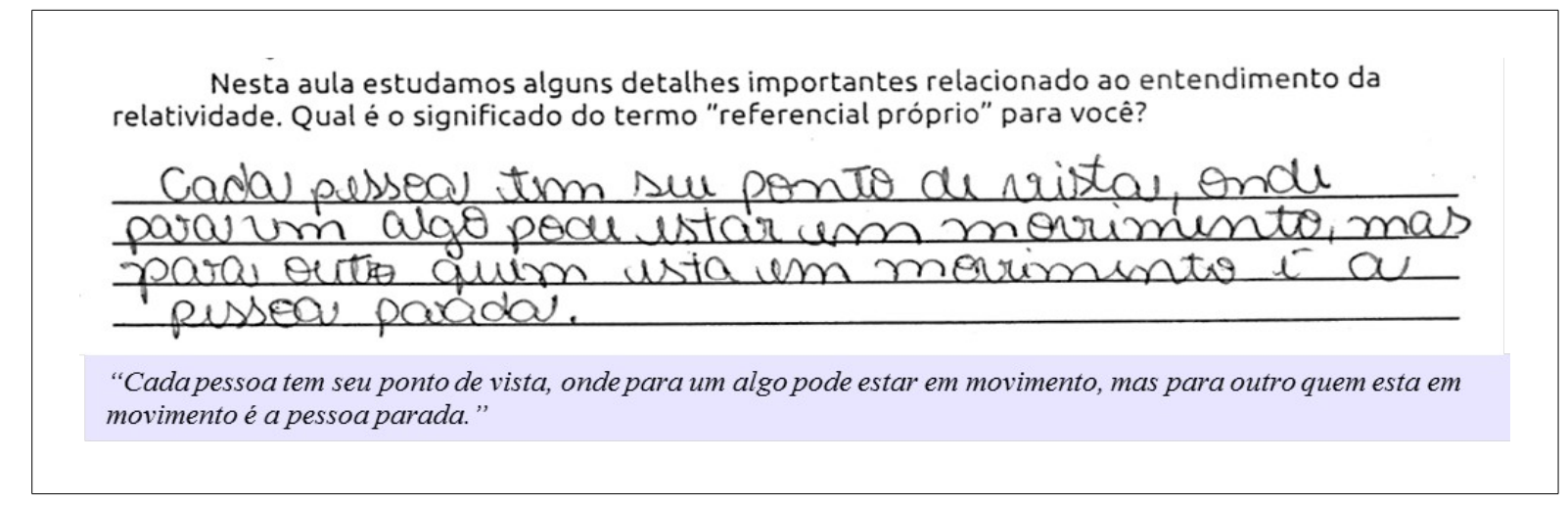

Figura 37 - Exemplar AproxMH(b2)* - Dimensão de Interface - Atv 5, turma BR2E - ficha 76:3. 
As respostas da $\operatorname{Aprox} \mathrm{MH}(\mathrm{b} 2)^{*}$ apresentam ideias gerais sobre referenciais, mas não identificam as diferenças entre o referencial próprio e o outro diferente. $\mathrm{Na}$ resposta presente na figura 37, o aluno tem dificuldades com o vocabulário necessário para verbalizar a resposta, mas apresenta uma articulação coerente com a relatividade.

As demais respostas desta subcategoria são similares ao exemplar.

AfastMH* Atv5: reúne as respostas insuficientes. Nesta subcategoria está aplicado os critérios de flexibilização da atividade 5 .

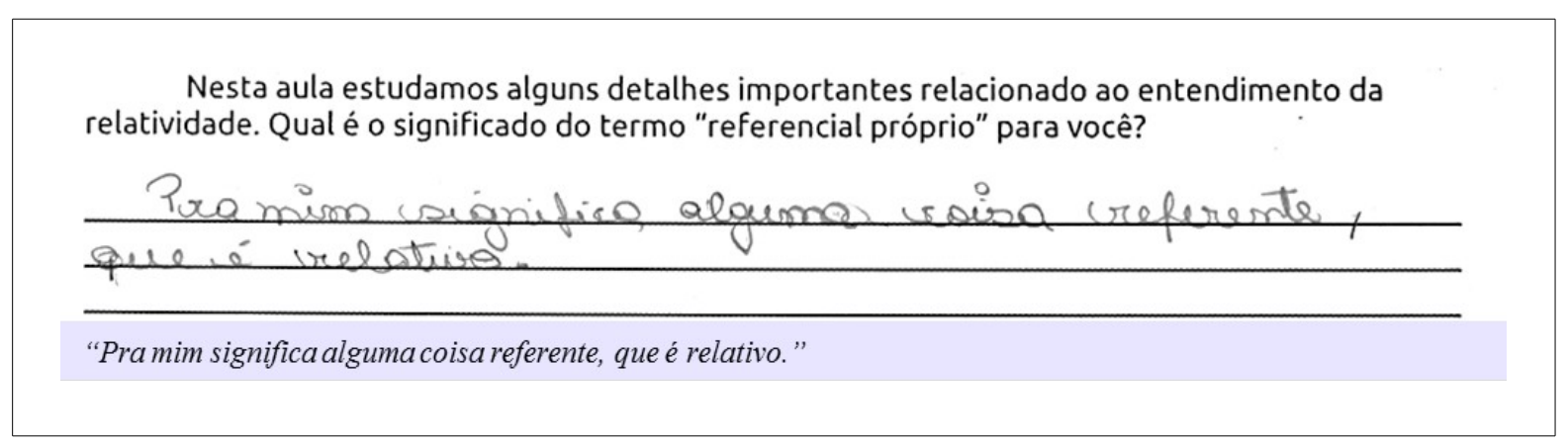

Figura 38 - Exemplar AfastMH - Dimensão de Interface - Atv 5, turma BR3E - ficha 58:8.

Nessa categoria encontram-se diversas respostas em que os alunos articulam os conceitos aprendidos de forma superficial e por vezes sem sentido identificável. Na figura 38, o aluno utiliza adjetivos genéricos como "referente" e "relativo" para significar o termo pedido. A resposta se torna insuficiente e longe dos conceitos pretendidos.

\begin{tabular}{|c|c|c|c|c|c|c|c|}
\hline \multicolumn{5}{|c|}{ Atividade 5 - Frequências para a Dimensão de Interface } & \multirow{2}{*}{\multicolumn{3}{|c|}{ ATV5 - D. Interface }} \\
\hline & BR3A & BR3E & BR2E & TOTAL: & & & \\
\hline AproxMH(a) Atv5 & 0 & 0 & 0 & 0 & \multirow[b]{2}{*}{64} & \multirow[b]{2}{*}{44} & \\
\hline AproxMH(b1) Atv5 & 5 & 4 & 4 & 13 & & & \\
\hline AproxMH(b2) Atv5 & 1 & 0 & 7 & 8 & $\square$ & n & \\
\hline AfastMH Atv5 & 4 & 4 & 8 & 16 & BR3A & BR3E & BR2E \\
\hline Branc/Incorr Atv5 & 8 & 4 & 0 & 12 & = Apr & $\mathrm{MH}=$ & fastMH \\
\hline TOTAL & 18 & 12 & 19 & 49 & & & \\
\hline
\end{tabular}

Quadro 24: Distribuição de respostas para subcategorias de interface e histograma da Atividade 5. O perfil apresentado ao lado da tabela não computa as respostas da categoria Branc/Incorr.

Acima segue o quadro 24 com a distribuição de respostas para as subcategorias de interface e um histograma com as frequências da dimensão de 
interface da atividade 5.

\subsubsection{Interface para a Atividade 6}

AproxMH(a) Atv6: agrupa as explicações que associam paradoxo, simetria entre os referenciais e passagem do tempo nos referenciais.

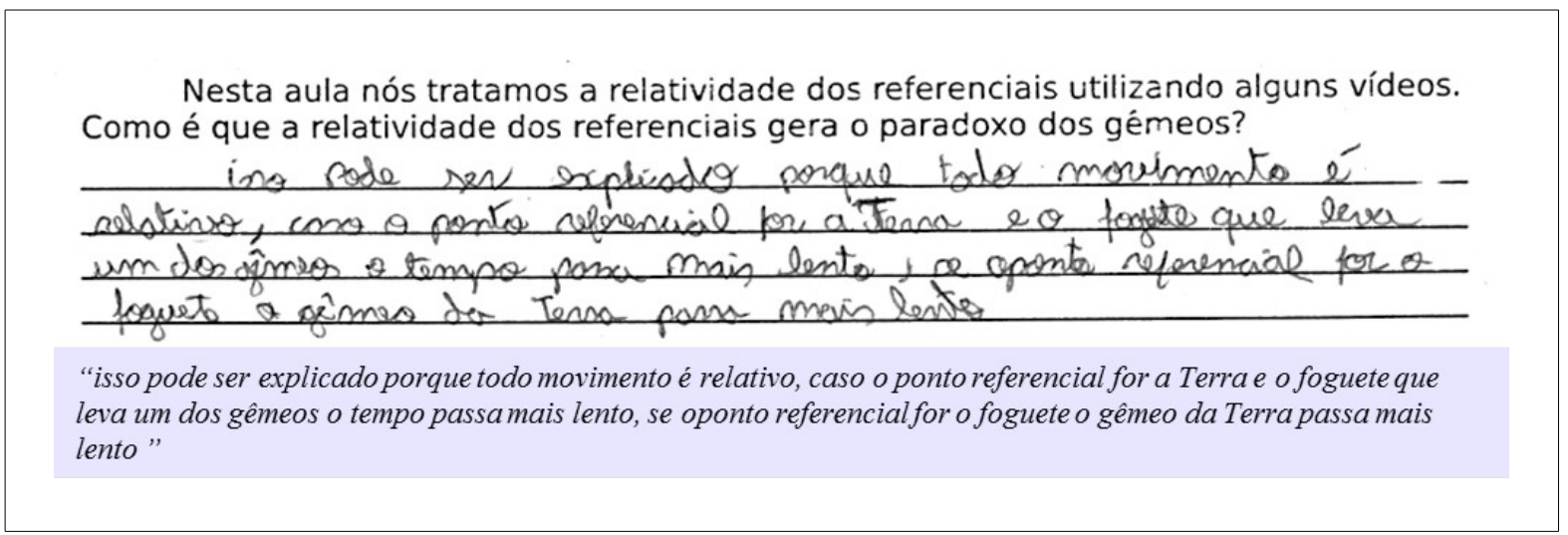

Figura 39 - Exemplar AproxMH(a) - Dimensão de Interface - Atv 6, turma BR3E - ficha 62:15.

O paradoxo dos gêmeos só pode ser compreendido quando já se conhece o fenômeno da diferenciação do tempo. Na figura 39, o aluno mostra possuir clareza sobre o significado do paradoxo, pois indica compreensão tanto sobre a troca de referenciais quanto a troca dos eventos que devem ser observados.

Todas as respostas desta subcategoria estão mais ou menos alinhadas à apresentada no exemplar: "É quando tipo um cara viaja pro espaço, na visão e quem ta na terra é o outro que vai envelhese, mais ja na visão de que ta em movimento é o que ta na terra que vai envelhece " (aluno, BR2E).

AproxMH(b) Atv6: esta subcategoria agrupa as respostas que explicam a relatividade dos referenciais associando as diferentes perspectivas de forma imprecisa e sem apontar a diferenciação temporal.

Para compreender a categorização desta resposta, é necessário observar que, no problema posto na atividade 6 , o observador é apresentado como se estivesse na Terra. Na resposta da figura Erro: Origem da referência não encontrada o aluno explora a perspectiva complementar não tratada no problema, ou seja, a do foguete. 
Nesta aula nós tratemos a relatividade dos referenciais utilizânco alguns vídeos. Como é que a relatividade dos referenciais gera o paradoxo dos gêmeos?

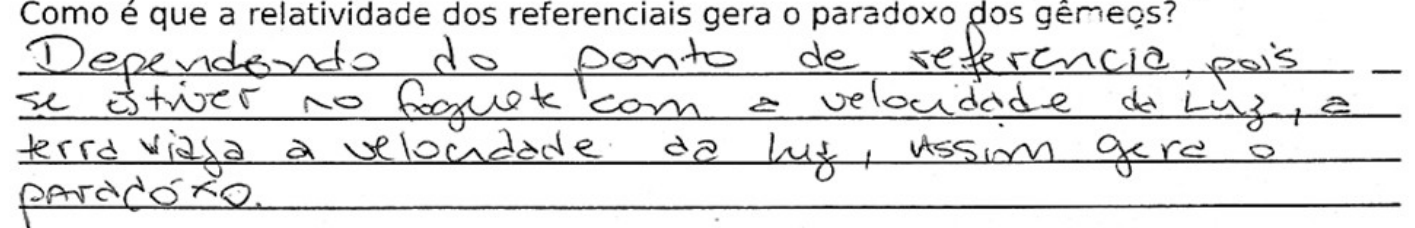

"Dependendo do ponto de referencia, pois se estiver no foguete com a velocidade da luz, a terra viaja a velocidade da luz, assim gera o paradóxo."

Figura 40 - Exemplar AproxMH(b) - Dimensão de Interface - Atv 6, turma BR3A - ficha 60:16.

O erro com relação à velocidade da viagem na afirmação “(...) viaja a velocidade da luz" é recorrente em outras respostas e se configura um detalhe crítico. Vale citar a troca do termo "ponto de vista" por "ponto de referência" na resposta. Era esperado que os alunos trocassem esse termo diretamente por "referencial" tendo em vista o uso contínuo do termo por parte dos professores após a atividade 4.

Na resposta exemplar, o aluno não explicita a diferenciação temporal na sua explicação. O mesmo acontece em outros casos, por exemplo: "Cada um tem o seu pondo de vista, o que está em movimento pensa o que está movimentando e o que esta parado, pensa que quem esta em movimento é quem está se movendo." (aluno, BR2E).

De forma geral, respostas assim foram categorizadas como próximas da moral da história porque trazem consigo a noção de simetria necessária à compreensão do paradoxo dos gêmeos.

AfastMH(c1) Atv6: agrupa as respostas que abordam a relatividade dos referenciais de forma confusa.

A resposta presente na figura 41 indica que o aluno não avançou com as ideias da atividade 5. Ele afirma que o Paradoxo está relacionado somente à diferenciação temporal e não à comparação entre referenciais. Nesse sentido, o aluno aparenta não ter capturado a essência da moral da história.

Outro conjunto de respostas aponta a mudança de referencial de forma confusa, por exemplo: "Paradoxo dos gêmeos é o que se contra diz de acordo com ponto de vista de quem esta se movimentando" (aluno, BR3E). 
Nesta aula nós tratamos a relatividade dos referenciais utilizando alguns vídeos. Como é que a relatividade dos referenciais gera o paradoxo dos gêmeos?

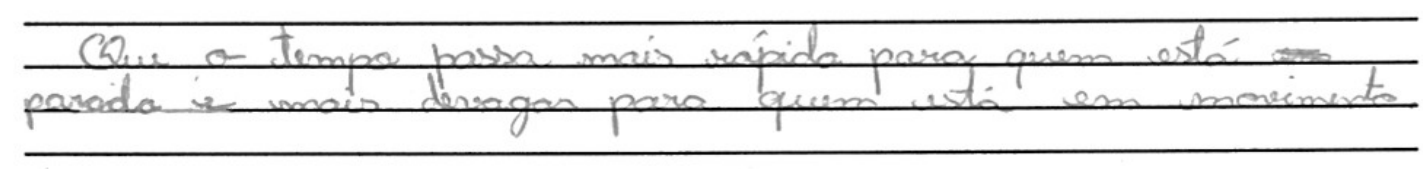

"Que o tempo passa mais rápido para quem está parado e mais devagar para quem está em movimento"

Figura 41 - Exemplar AfastMH(c1) - Dimensão de Interface - Atv 6, turma BR2E - ficha 77:5.

AfastMH(c2) Atv6: respostas insuficientes ou distantes da moral da história.

A figura 42 exemplifica um grande conjunto de respostas que aparentemente procuram elencar elementos abordados na atividade de modo impreciso. Nesse caso, o aluno traz de forma incoerente alguma noção sobre os referenciais. Com base na quantidade de respostas nessa categoria, talvez seja necessário rever a própria questão presente no instrumento.

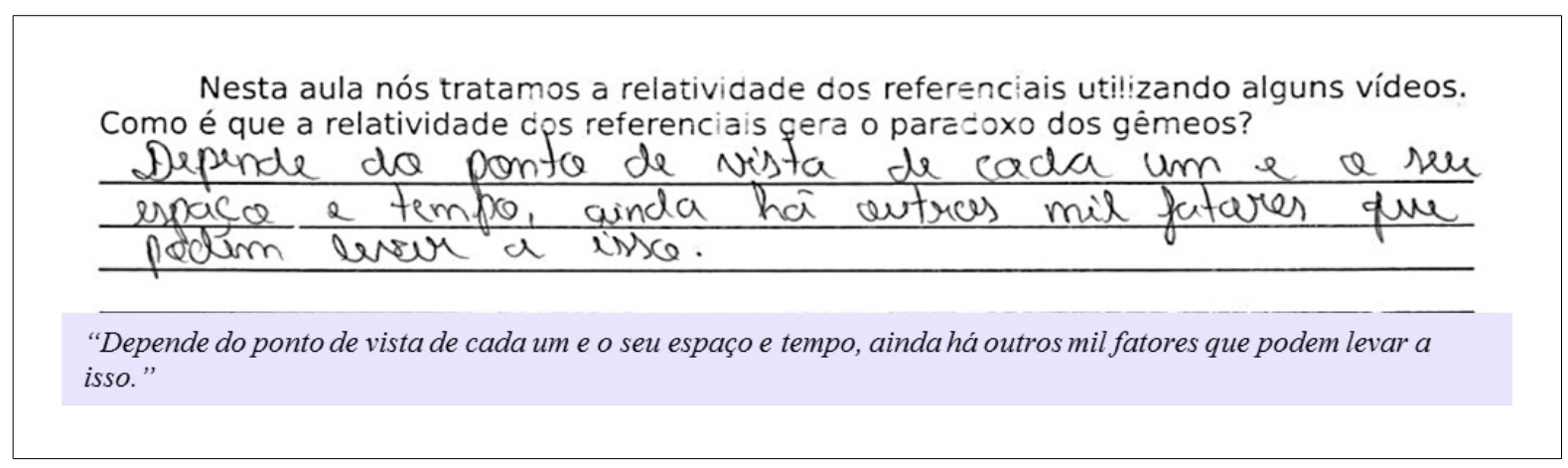

Figura 42 - Exemplar AfastMH(c2) - Dimensão de Interface - Atv 6, turma BR3E - ficha 63:1.

Abaixo segue o quadro 25 com a distribuição de respostas para as subcategorias de interface e um histograma com as frequências da dimensão de interface da atividade 6 . 
Atividade 6 - Frequências para a Dimensão de Interface

\begin{tabular}{|c|c|c|c|c|c|c|c|}
\hline \multicolumn{5}{|c|}{ Aliviadue o-riequencids } & \multirow{2}{*}{\multicolumn{3}{|c|}{$\underset{20}{\text { ATV6 - D. Interface }}$}} \\
\hline & BR3A & BR3E & $\mathrm{BR} 2 \mathrm{E}$ & TOTAL: & & & \\
\hline AproxMH(a) Atv6 & 0 & 2 & 4 & 6 & \multirow[b]{2}{*}{2} & \multirow[t]{2}{*}{13} & \multirow{2}{*}{109} \\
\hline AproxMH(b) Atv6 & 2 & 2 & 6 & 10 & & & \\
\hline AfastMH(c1) Atv6 & 4 & 2 & 3 & 9 & - & a & \\
\hline AfastMH(c2) Atv6 & 16 & 11 & 6 & 33 & BR3A & BR3E & $\mathrm{BR} 2 \mathrm{E}$ \\
\hline Branc/Incorr Atv6 & 4 & 4 & 0 & 8 & \multirow{2}{*}{\multicolumn{2}{|c|}{ AproxMH }} & \multirow{2}{*}{ AfastMH } \\
\hline TOTAL & 26 & 21 & 19 & 66 & & & \\
\hline
\end{tabular}

Quadro 25: Distribuição de respostas para subcategorias de interface e histograma da Atividade 6. O perfil apresentado ao lado da tabela não computa as respostas da categoria Branc/lncorr.

\subsubsection{Interface para a Atividade 7}

Esta questão solicita aos alunos efetuarem um cálculo de velocidade média. Vários alunos desenvolveram tais cálculos em folha separada e a maioria das fichas analisadas não possuíam o desenvolvimento matemático de forma expressa.

AproxMH(a) Atv7: compreende as respostas em que os cálculos concluem $\mathrm{v}=0,5 \mathrm{~m} / \mathrm{s}$.

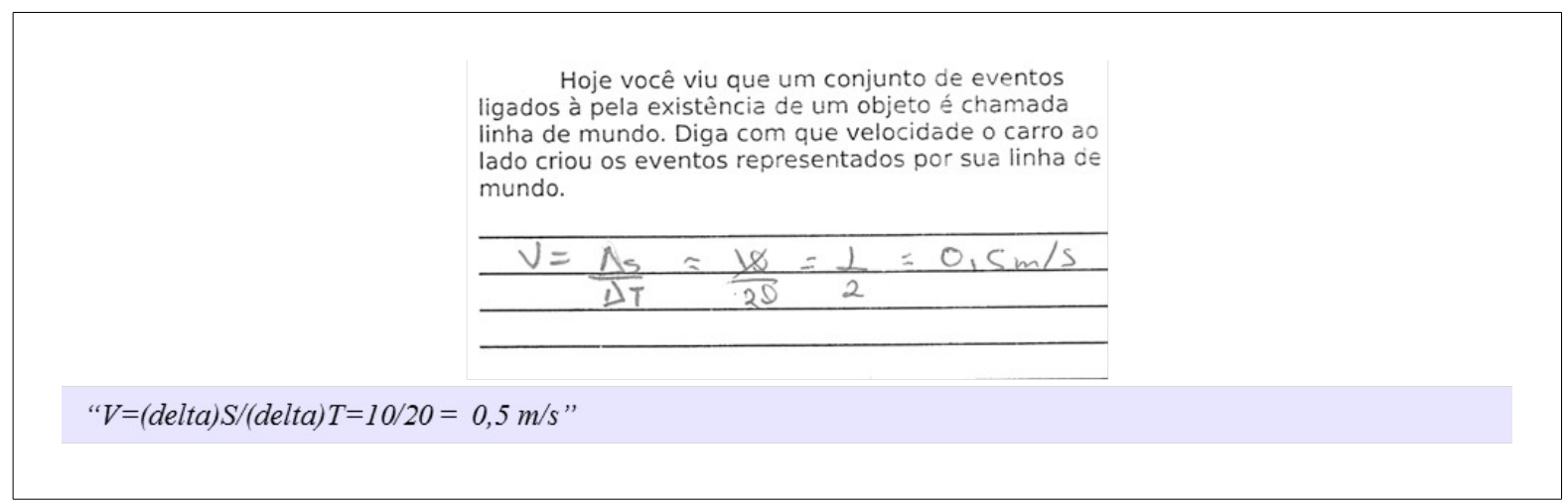

Figura 43 - Exemplar AproxMH(a) - Dimensão de Interface - Atv 7, turma BR3A - ficha 64:24.

$\mathrm{Na}$ figura 43 o aluno apresenta a resposta numericamente correta para o problema mostrando capacidade de articular matematicamente a representação geométrica em direção à representação algébrica. 
De forma geral, a categorização da atividade 7 proporcionou bastante dificuldade porque os alunos não fizeram os cálculos na ficha do instrumento de fluxo. Deste modo, as respostas desta subcategoria são praticamente iguais.

AproxMH(b) Atv7: as respostas que indicam o cálculo feito com base na posição do ícone que representa o carro em vez de utilizar a linha de mundo. Nessa condição a resposta dada é $v=0,45 \mathrm{~m} / \mathrm{s}$.

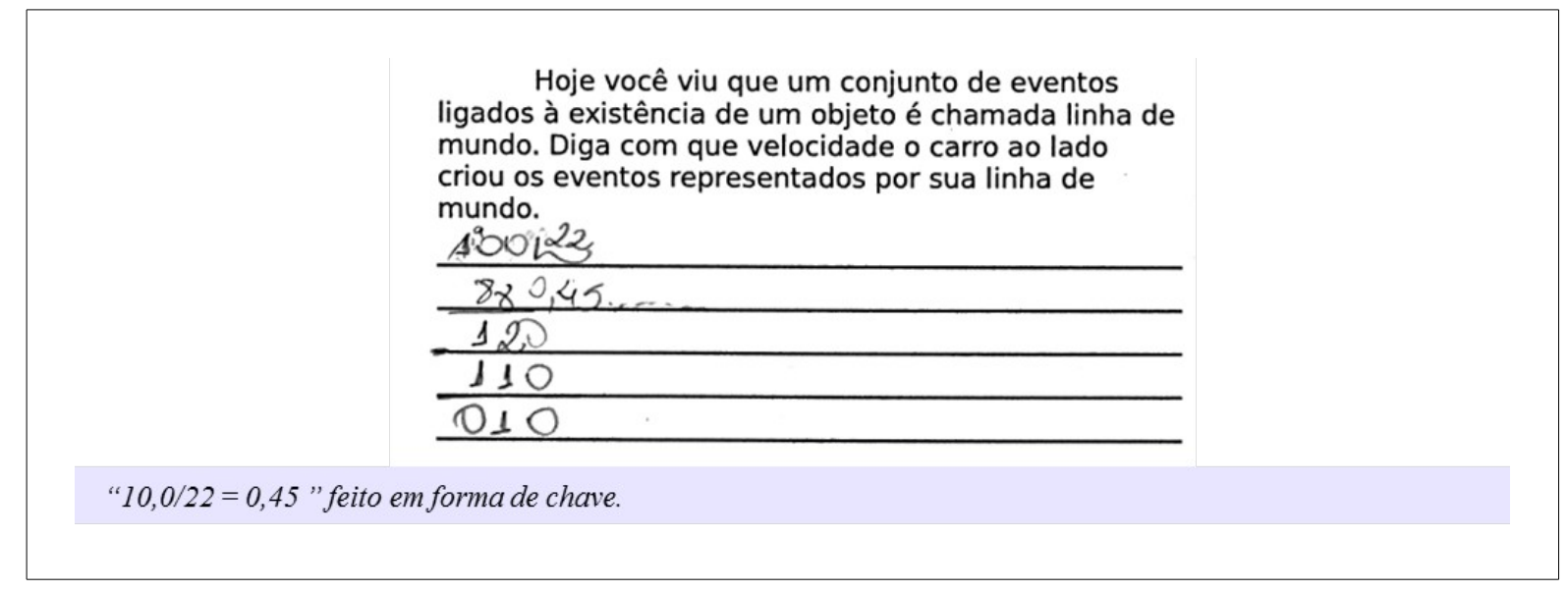

Figura 44 - Exemplar AproxMH(b) - Dimensão de Interface - Atv 7, turma BR2E - ficha 78:18.

Nessa resposta na figura 5, o aluno demonstra pouca habilidade em lidar com gráficos. Durante a resolução considerou a posição do ícone que representava o carro em vez de utilizar a linha de mundo em seus cálculos (figura 12 na página 103). Nesse caso, a divisão foi feita em chave e por extenso na ficha.

AfastMH Atv7: respostas insuficientes ou distantes da moral da história.

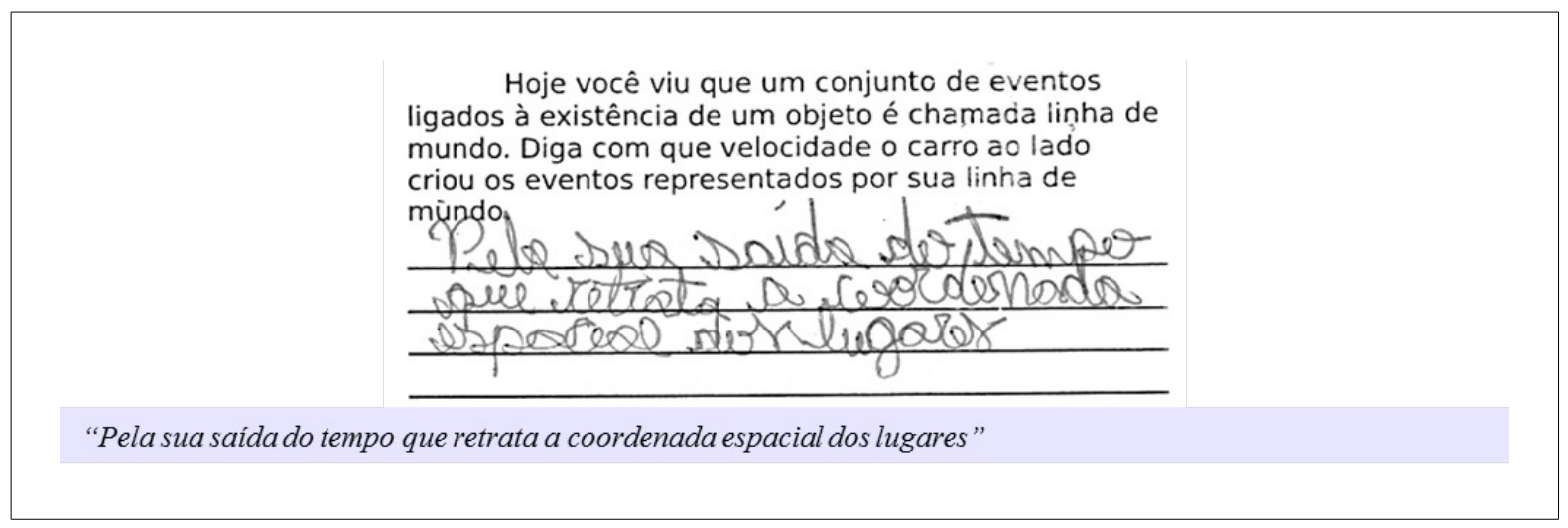

Figura 45 - Exemplar AfastMH - Dimensão de Interface - Atv 7, turma BR3E - ficha 65:14. 
A figura 45 mostra uma resposta incoerente com a esperada. Houve um grande grupo de respostas apontou soluções com o equacionamento invertendo espaço por tempo, apresentando valores estranhos em outras unidades de medida, entre outros.

\begin{tabular}{|c|c|c|c|c|c|c|c|}
\hline \multicolumn{5}{|c|}{ Atividade 7 - Frequências para a Dimensão de Interface } & \multicolumn{3}{|c|}{ ATV7 - D. Interface } \\
\hline & BR3A & BR3E & BR2E & TOTAL: & 16 & & 1314 \\
\hline AproxMH(a) Atv7 & 16 & 0 & 4 & 20 & 5 & 105 & 1314 \\
\hline AproxMH(b) Atv7 & 0 & 10 & 9 & 19 & m & $\square$ & \\
\hline AfastMH Atv7 & 5 & 5 & 14 & 33 & BR3A & BR3E & $\mathrm{BR} 2 \mathrm{E}$ \\
\hline Branc/Incorr Atv7 & 7 & 4 & 1 & 3 & & & \\
\hline TOTAL & 28 & 19 & 28 & 75 & & $\mathrm{NIH}$ & \\
\hline
\end{tabular}

Quadro 26: Distribuição de respostas para subcategorias de interface e histograma da Atividade

7. O perfil apresentado ao lado da tabela não computa as respostas da categoria Branc/lncorr.

Acima segue o quadro 26 com a distribuição de respostas para as subcategorias de interface e um histograma com as frequências da dimensão de interface da atividade 7.

\subsubsection{Interface para a Atividade 8}

AproxMH(a) Atv8: respostas que expliquem algum tipo de invariância como o intervalo relativístico, a constância da velocidade da luz ou dos eventos.

Não houve respostas categorizadas.

AproxMH(b1) Atv8: respostas que apontem que o intervalo relativístico é sempre o mesmo para qualquer observador.

$\mathrm{Na}$ resposta presente na figura 46, o aluno acerta quando afirma sobre a necessidade da existência de um "tempo" que não mudasse. Aparentemente, essa troca do termo "intervalo relativístico" pela palavra "tempo" é resultado da analogia proposta entre ambos na atividade 8 . Há no final da frase uma referência à velocidade da luz, ela pode ser um segundo exemplo de absoluto ou ter sido a indicação de uma mistura confusa de conceitos porque parece ter sido tomada como um referencial. 
Respostas deste tipo convergem para o fluxo porque buscam um termo ou expressão para um "tipo de tempo que não muda", em essência, um absoluto.

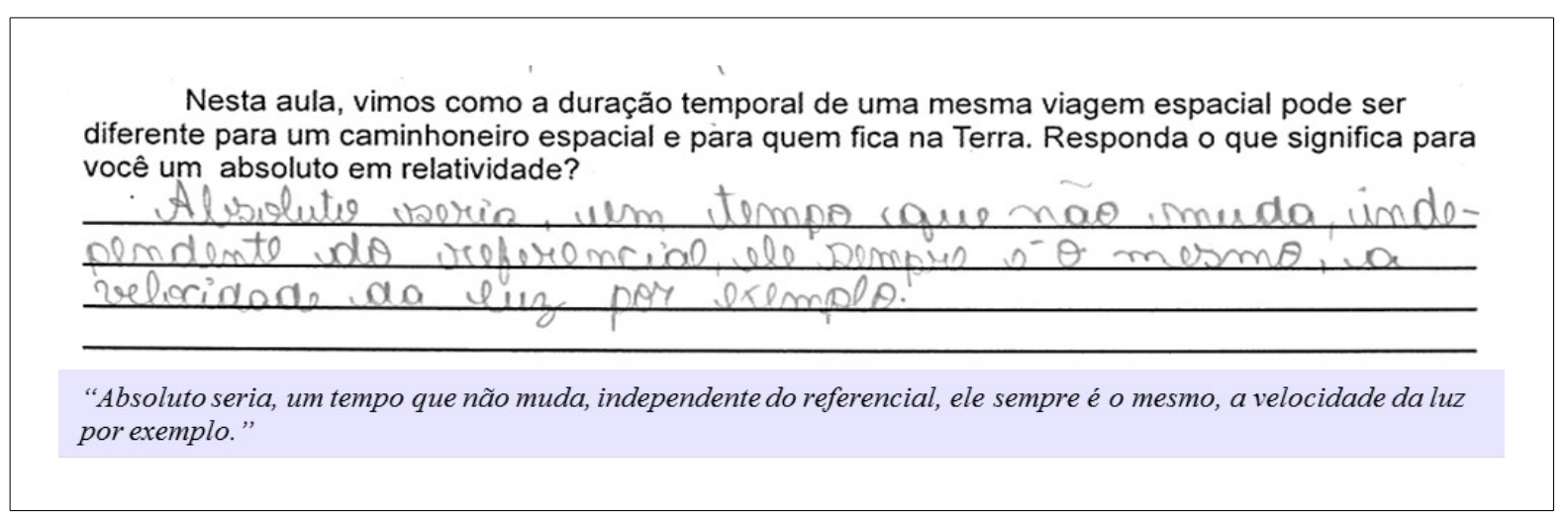

Figura 46 - Exemplar AproxMH(b1) - Dimensão de Interface - Atv 8, turma BR2E - ficha 78:14.

AproxMH(b2) Atv8: agrupa as respostas que aponte outros elementos absolutos na RR.

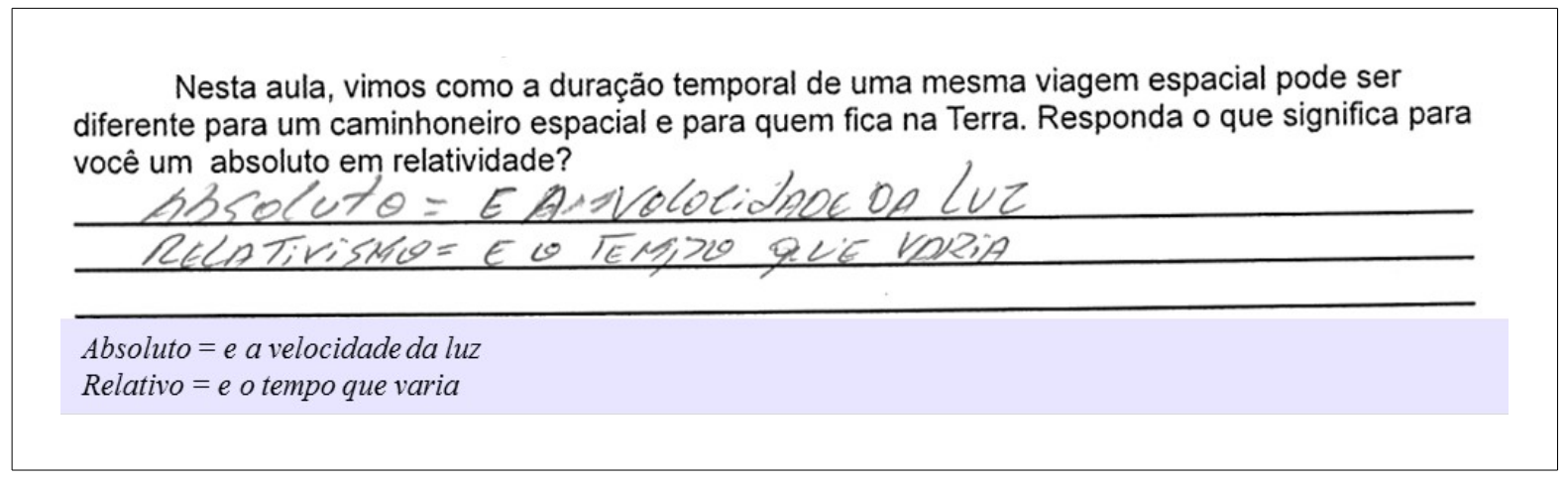

Figura 47 - Exemplar AproxMH(b2) - Dimensão de Interface - Atv 8, turma BR2E - ficha 80:24.

A resposta na figura 47 elenca corretamente e de forma objetiva os elementos absolutos. Quando afirma que "relativo $=$ e o tempo que varia" parece tentar diferenciar o "tempo" clássico do "intervalo relativístico". Em todos as respostas desta categoria, o elemento elencado pelo aluno foi a velocidade da luz.

AfastMH: categoriza as respostas insuficientes ou distantes da moral da história. 
Nesta aula, vimos como a duração temporal de uma mesma viagem espacial pode ser diferente para um caminhoneiro espacial e para quem fica na Terra. Responda o que significa para você um absoluto em relatividade?

(1) tempo is aboluto para quem rie; í abosoluto. para cada um

"O tempo é absolutoparaquem vê; é absoluto paracadaum"

Figura 48 - Exemplar AfastMH - Dimensão de Interface - Atv 8, turma BR2E - ficha 79:6.

A figura 48 indica uma confusão que não era esperada na penúltima atividade. O aluno faz associações confusas onde o absoluto e o relativo. A dificuldade com relação ao conceito de tempo não era esperada na etapa final da sequência didática.

Abaixo segue o quadro $27 \mathrm{com}$ a distribuição de respostas para as subcategorias de interface e um histograma com as frequências da dimensão de interface da atividade 8.

\begin{tabular}{|c|c|c|c|c|c|c|c|}
\hline \multicolumn{5}{|c|}{ Atividade 8 - Frequências para a Dimensão de Interface } & \multirow{2}{*}{\multicolumn{3}{|c|}{ ATV8 - D. Interface }} \\
\hline & BR3A & BR3E & $\mathrm{BR} 2 \mathrm{E}$ & TOTAL: & & & \\
\hline AproxMH(a) Atv8 & 2 & 0 & 0 & 0 & \multirow{3}{*}{9} & \multirow{3}{*}{46} & \multirow{2}{*}{99} \\
\hline AproxMH(b1) Atv8 & 1 & 1 & 5 & 5 & & & \\
\hline AproxMH(b2) Atv8 & 6 & 3 & 4 & 4 & & & \multirow{2}{*}{$\mathrm{BR} 2 \mathrm{E}$} \\
\hline AfastMH Atv8 & 4 & 6 & 9 & 9 & BR3A & BR3E & \\
\hline Branc/Incorr Atv8 & 13 & 1 & 1 & 1 & \multirow{2}{*}{\multicolumn{3}{|c|}{ AproxMH = AfastMH }} \\
\hline TOTAL & 26 & 11 & 19 & 19 & & & \\
\hline
\end{tabular}

Quadro 27: Distribuição de respostas para subcategorias de interface e histograma da Atividade 8. O perfil apresentado ao lado da tabela não computa as respostas da categoria Branc/Incorr.

\subsubsection{Interface para a Atividade 9}

AproxMH(a) Atv9: reúne as respostas que explicam a diferença de idade com base em diferenças nas linhas de mundo de cada irmão.

Na figura 49, a afirmação "adam está só no percurso do tempo", sugere que o aluno compreendeu a ideia de deslocamento temporal. Além disso, faz uma 
comparação geométrica com base na simetria dos percursos. Ele se engana quando indica a existência de um "verdadeiro movimento".

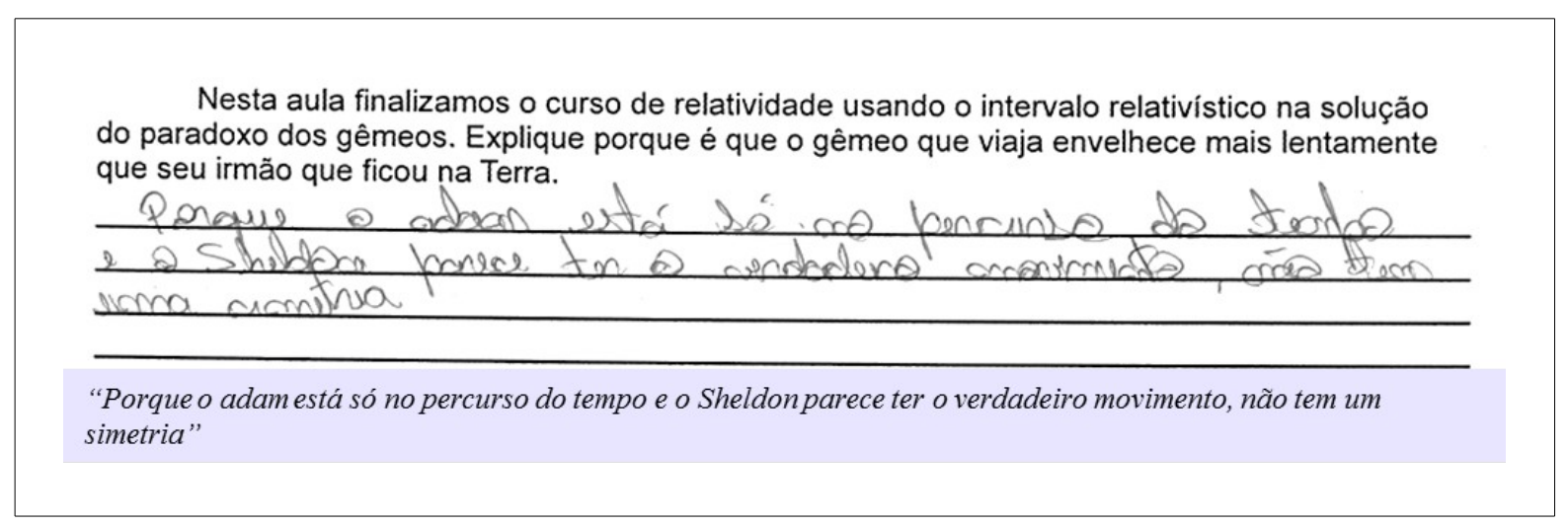

Figura 49 - Exemplar AproxMH(a) - Dimensão de Interface - Atv 9, turma BR2E - ficha 80:2.

A segunda resposta que compõe esta categoria "Porque ele está numa velocidade alta e não segue uma linha reta, ele uma linha curva." (aluno, BR2E), apresenta dificuldades com o vocabulário e desatenção à escrita, entretanto apresenta um argumento geométrico coerente com a moral da história.

AproxMH(b) Atv9: esta subcategoria engloba as respostas que argumentam usando a quebra de simetria presente nas linhas de mundo.

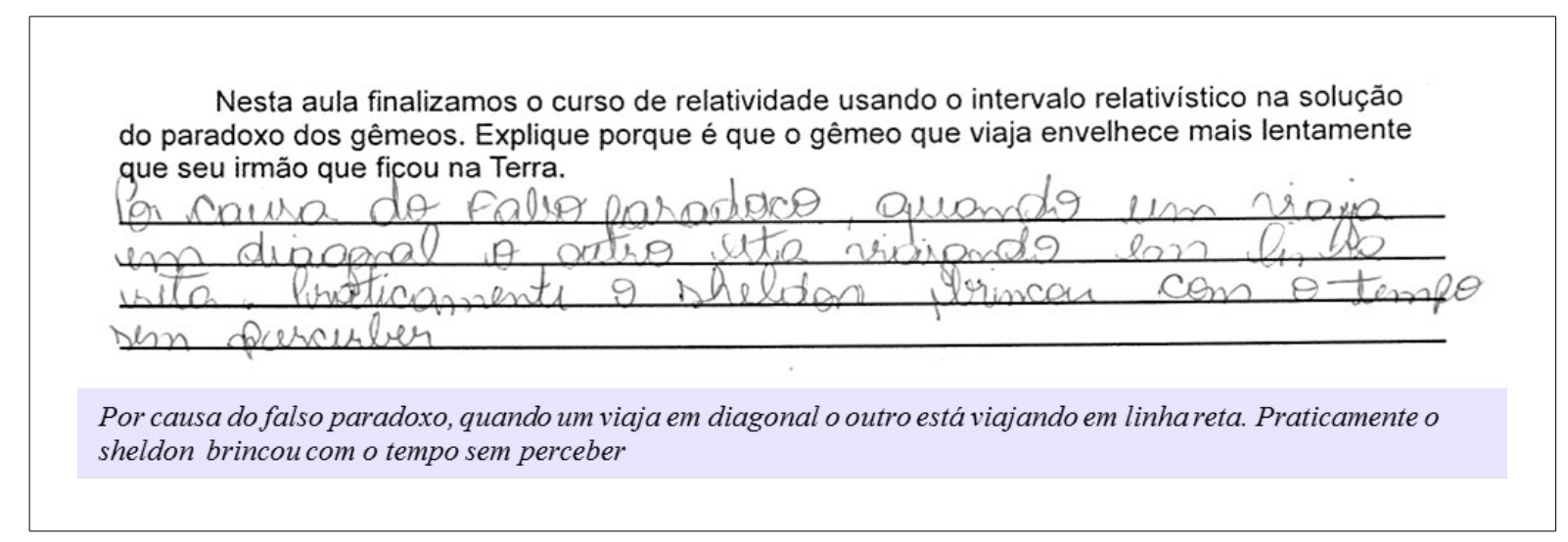

Figura 50 - Exemplar AproxMH(b1) - Dimensão de Interface - Atv 9, turma BR2E - ficha 80:13.

$\mathrm{Na}$ resposta da figura 50, o aluno trata a questão utilizando um argumento geométrico sobre as linhas de mundo. As outra duas respostas indicam objetivamente que a diferença de idade entre os irmãos ocorre por quebra de simetria. 
AfastMH(c1) Atv9: reúne respostas que consideram o movimento como responsável pela diferença de idade, mas não indicam compreensão do Paradoxo dos Gêmeos verdadeiro.

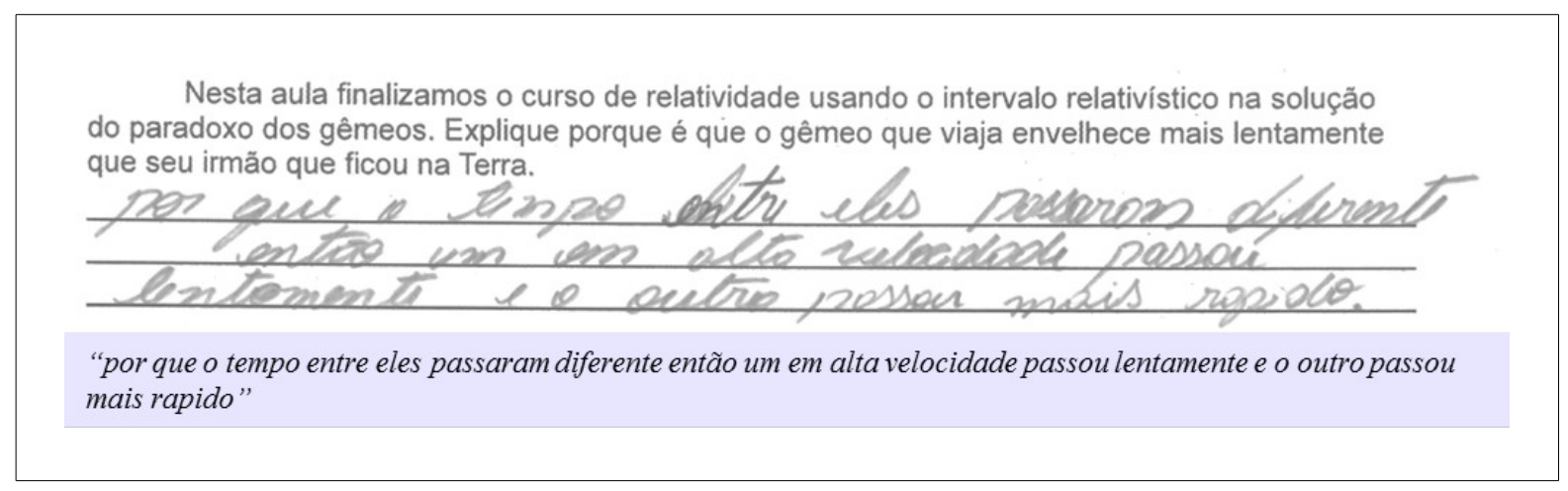

Figura 51 - Exemplar AproxMH(b2) - Dimensão de Interface - Atv 9, turma BR2E - ficha 79:13.

A resposta presente na figura 51 não deixa clara a compreensão sobre a simetria presente na situação entre os dois irmãos. Aparentemente relaciona a diferença na passagem do tempo causada pela velocidade relativa diretamente ao paradoxo dos gêmeos. Isso sugere que seu entendimento sobre o paradoxo se limita à compreensão da diferenciação do tempo.

Várias respostas seguiram esse mesmo caminho ao indicar que a causa do paradoxo dos gêmeos se restringe à diferenciação temporal como no caso estudado na atividade 5. Essas respostas não se aproximam da moral da história esperada.

AfastMH(c2) Atv9: agrupa as respostas insuficientes ou distantes da moral da história.

Nesta aula finalizamos o curso de relatividade usando o intervalo relativístico na solução do paradoxo dos gêmeos. Explique porque é que o gêmeo que viaja envelhece mais lentamente gue seu irmão que ficou na Terra.

Eu acho que é um paradoxe, mas poderá ser verdade per causa da velecidade de luz

"Eu acho que é um paradoxo, mas poderáser verdade por causa da velocidade da luz."

Figura 52 - Exemplar AfastMH - Dimensão de Interface - Atv 9, turma BR3A - ficha 66:14.

Na figura 52 a resposta do aluno aparentemente toma a palavra "paradoxo" como sinônimo da palavra "mentira". De forma geral, as demais respostas 
apresentam respostas diversas, por exemplo: "Porque o irmão mais velho ficou "parado" por 20 anos, e o outro ficou viajando por 12 anos."(aluno, BR2E), ou ainda "Porque o gêmeo que viaja o tempo não passa direto, como o do que ficou na terra." (aluno, BR2E).

Abaixo segue o quadro 28 com a distribuição de respostas para as subcategorias de interface e um histograma com as frequências da dimensão de interface da atividade 9.

\begin{tabular}{|c|c|c|c|c|c|c|c|}
\hline \multicolumn{5}{|c|}{ Atividade 9 - Frequências para a Dimensão de Interface } & \multirow{2}{*}{\multicolumn{3}{|c|}{ ATV9 - D. Interface }} \\
\hline \multirow[b]{2}{*}{ AproxMH(a) Atv9 } & \multirow{2}{*}{$\begin{array}{c}\text { BR3A } \\
0\end{array}$} & \multirow{2}{*}{$\begin{array}{c}\text { BR3E } \\
0\end{array}$} & \multirow{2}{*}{$\begin{array}{c}\text { BR2E } \\
2\end{array}$} & \multirow{2}{*}{$\begin{array}{c}\text { TOTAL: } \\
2\end{array}$} & & & \\
\hline & & & & & 13 & & 17 \\
\hline AproxMH(b) Atv9 & 0 & 0 & 3 & 3 & 0 & 00 & J \\
\hline AfastMH(c1) Atv9 & 7 & 0 & 10 & 17 & & & \\
\hline AfastMH(c2) Atv9 & 6 & 0 & 7 & 13 & BR3A & BR3E & BR2E \\
\hline Branc/Incorr Atv9 & 4 & 0 & 6 & 10 & $\square$ Aprc & $\mathrm{MH}$ & AfastMH \\
\hline TOTAL & 17 & 0 & 28 & 45 & & & \\
\hline
\end{tabular}

Quadro 28: Distribuição de respostas para subcategorias de interface e perfil da Atividade 9.

Os histogramas apresentam as frequências da dimensão de interface. Neles, as subcategorias $\mathrm{AproxMH}(\mathrm{a})$ e $\mathrm{AproxMH}(\mathrm{b})$ são unificadas na categoria AproxMH permitindo comparação com a AfastMH. Nesses histogramas não foram contabilizadas as frequências relativas à $\operatorname{AfastMH}(\mathrm{d})$.

As atividades 2, 6 e 9 apresentaram uma grande quantidade de respostas que se afastam da moral da história. Com relação à atividade 2, essa diferença pode ser vista no quadro 21. Uma possível explicação para esta discrepância talvez esteja na ênfase dada à resolução do problema 4 proposto no material. A resolução deste problema tomou grande parte de todas as aula. Isso provavelmente teve maior relevância, especialmente ao final da aula, induzindo-o a associar a questão do instrumento de fluxo à resolução que acabara de ser feita.

O quadro 25 da atividade 6 também mostra um número expressivo de respostas que se afastavam da moral da história para as turmas BR3A e BR3E. A atividade 6 propõe um jogo didático que envolve a produção antecipada de vídeos pelos alunos. A explicação para estes dois casos está associada às dificuldades encontradas pelo professor A em promover a participação dos alunos na produção desses vídeos. Como não houve o engajamento de apenas um grupo de alunos na 
criação do vídeo, o professor precisou improvisar a atividade 6. Atividades relativas ao final do ano tais como comissões de formatura e campeonatos desportivos associados a um calendário escolar pouco definido foram os motivos de tão baixa aderência para esta atividade.

A relação ruim entre as respostas dos alunos e a moral da história da atividade 9 , indicada no histograma do quadro 27 , pode estar relacionada à própria questão. Assim como acontece com a questão da atividade 6 , a questão apresentada para os alunos ao final da sequência didática possui uma característica sistematizadora e específica exigindo a articulação de diversos conceitos até então pouco usados.

Ainda sobre as respostas da atividade 9, a turma BR3E não possui dados porque o instrumento de fluxo não fora aplicado pelo professor. A turma BR3A, por sua vez, não teve nenhuma aproximação da moral da história para a atividade 9 . Um dos motivos agravadores pode estar associado à desmotivação e evasão dos alunos, uma vez que o relato do professor $A$ aponta que a programação de ambas as turmas foram prejudicadas por mudanças ou superposições no calendário escolar. A turma BR2E também apresentou baixa aproximação das respostas ao fluxo da sequência, mas não há nenhum elemento explícito que tenha colaborado com isso. Essa situação aponta grande probabilidade da atividade em si não ter sido suficiente para alcançar a moral da história proposta.

As atividade 3, 5, 8 (quadros 22, 24 e 27) mostraram-se equilibradas quanto à quantidade de respostas que se aproximam da moral da história, mas é importante lembrar sobre a flexibilização feita nos critérios da atividade 5 .

A atividade 7 foi tida à primeira vista pelos próprios professores e pesquisador como de complexa aplicação. Sua problematização possui elementos cotidianos que contrastam com as problematizações baseadas em viagens espaciais fictícias das atividades anterior e posterior a ela. A metodologia exige uma dinâmica de aula na qual as conclusões finais dependem do sucesso dos grupos na execução das tarefas. Após aplicação, os próprios professores sugeriram que essa atividade fosse excluída da sequência em virtude de uma série de dificuldades metodológica. Entretanto, como pode ser visto no quadro 26, as respostas dos alunos possuem uma relação positiva entre AproxMH e AfastMH. Esse resultado talvez esteja ligado à forma dinâmica com que a atividade fora pensada.

A atividade 4 possui a melhor relação entre as categorias AproxMH e 
AfastMH como pode ser visto no quadro 24.

\subsubsection{Análise da dimensão de fluência}

A dimensão de fluência categoriza as respostas com base nas alternativas apontadas pelos alunos na $2^{\mathrm{a}}$ etapa do instrumento de fluxo. Optou-se por normalizar os perfis pela quantidade de respostas efetivamente encontrada em cada conjunto de fichas coletado. Esse procedimento permite uma comparação direta entre turmas com quantidade de alunos diferentes. Entretanto é importante observar que quando o número de respostas em determinada categoria é pequena, é possível criar situações onde, por exemplo, a escolha de um aluno em determinada atividade possui o mesmo peso que a escolha de dois alunos em outra. Para ajudar a evitar esse problema, as barras correspondentes a cada categoria exibem a quantidade de respostas que as compõem.

Abaixo é possível observar o perfil do fluxo da aplicação junto às turmas BR3A, BR3E e BR3E. Nesses gráficos, são contabilizadas todas as respostas "acho que será" apontadas na segunda etapa do instrumento de fluxo.

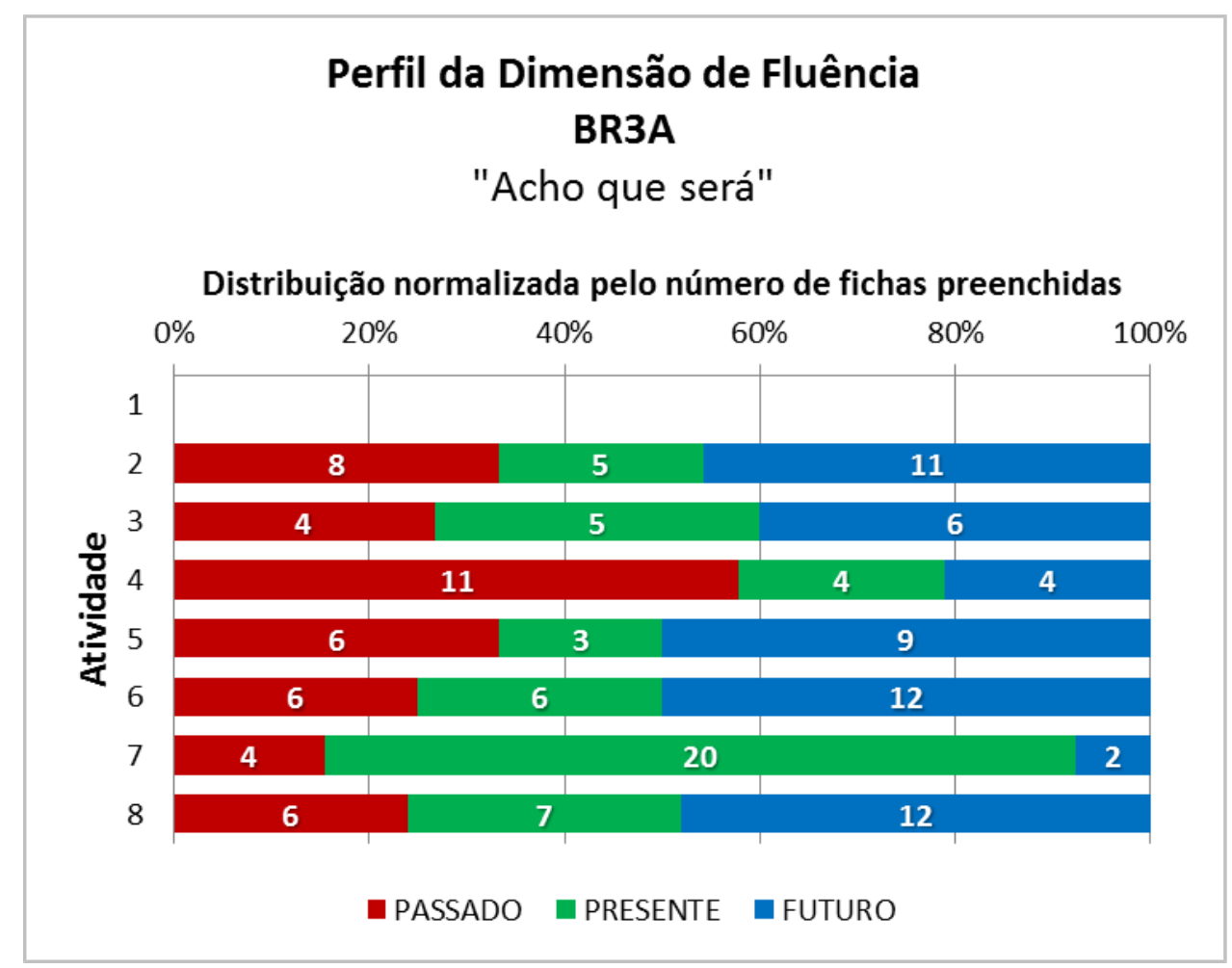

Gráfico 1: Perfil de fluência "acho que será" da turma BR3A. 


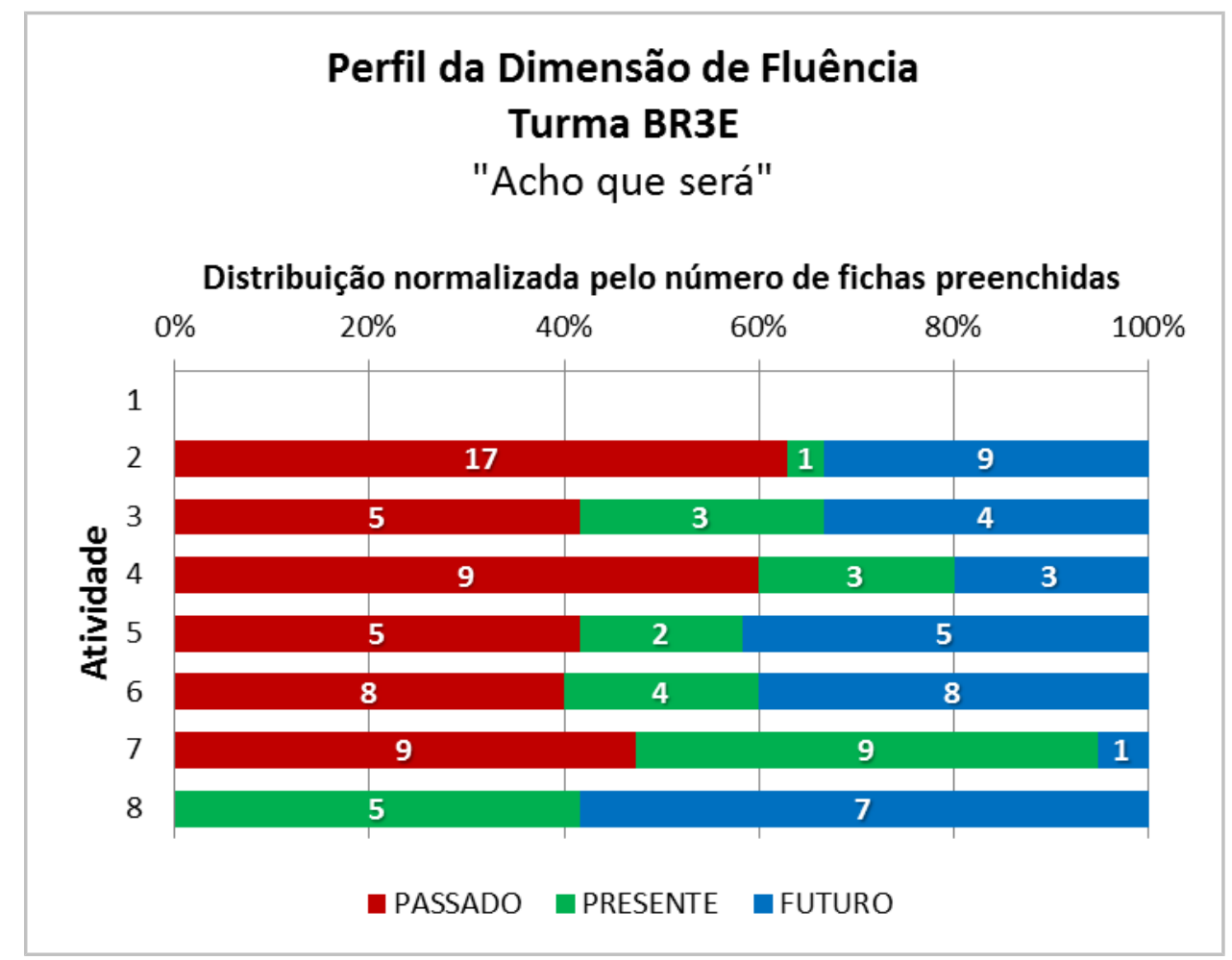

Gráfico 2: Perfil de fluência "acho que será" da turma BR3E.

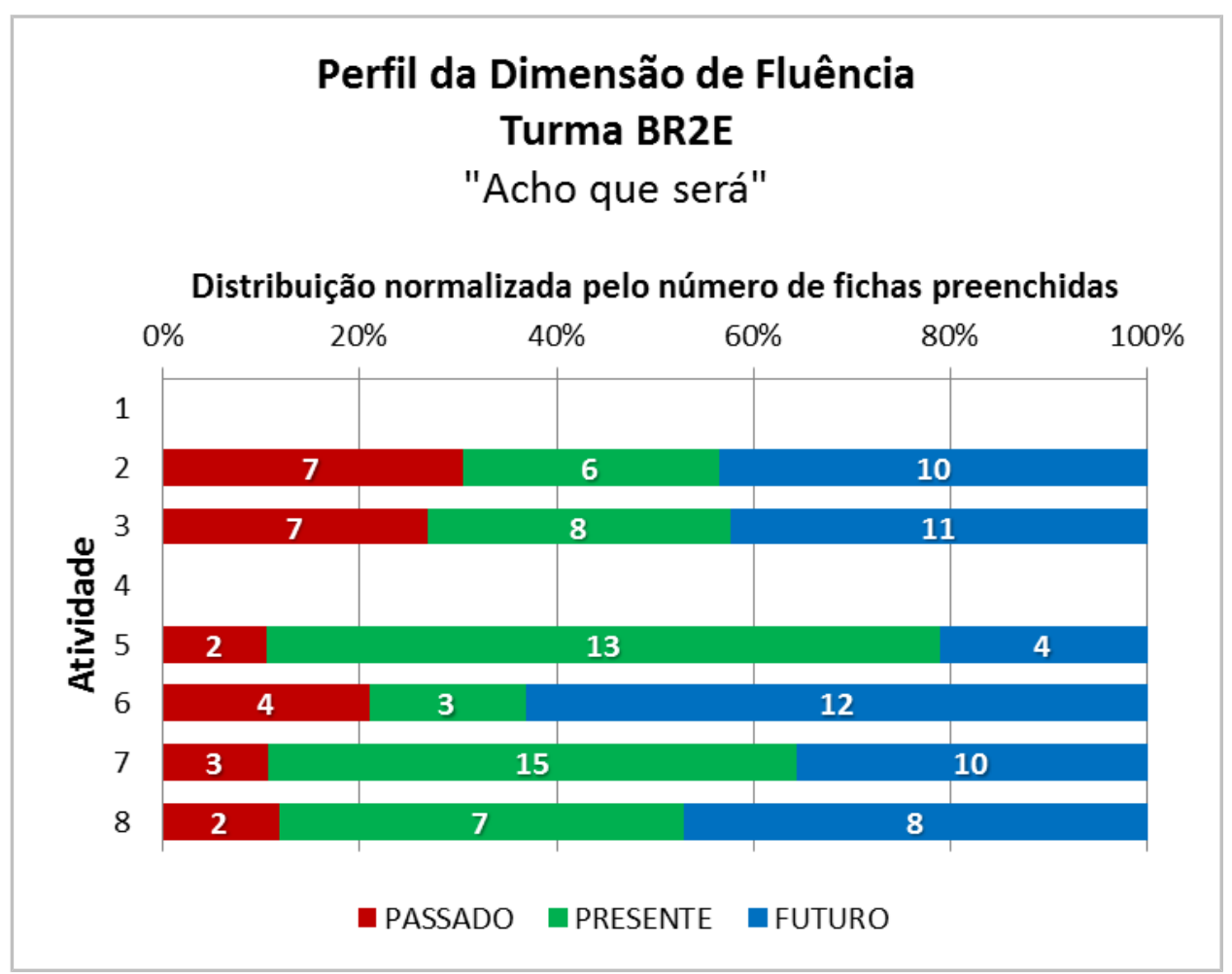

Gráfico 3: Perfil de fluência "acho que será" da turma BR2E. 
Com base na observação geral sobre distribuição de dados presente no gráfico 1, é possível perceber que a proporção das respostas tipo presente (ou seja, aquelas que efetivamente apontam para a atividade seguinte) é igual ou menor do que as demais e não varia conforme a evolução do curso. As maiores proporções se dividem entre as respostas do tipo passado e futuro sendo que o último é a maior em quase todas as atividades.

Isso indica que, de forma geral, a turma BR3A percebeu fracamente a fluência local proposta na transição entre as atividades. Entretanto, o saldo levemente positivo com relação às respostas tipo futuro indica que outra grande parcela de alunos perceberam a direção que o curso estava tomando conforme as atividades foram acontecendo.

Em contraste com esse quadro geral, a atividade 7 se destaca por possuir $80 \%$ das respostas do tipo presente, ou seja, um grande número de alunos apontou efetivamente que a próxima atividade seria a de número 8. Um comportamento parecido, mas em menor intensidade, é encontrado também nas turmas BR3E e BR2E conforme pode ser visto nos gráficos 2 e 3 . Essa característica, como apontado anteriormente, possivelmente esteja associada à forma participativa que a atividade ocorre em classe. É provável que esse aspecto tenha promovido maior compreensão da posição didática daquela atividade diante das demais. Outro ponto interessante é uma possível relação entre a etapa 1 e a etapa 2 . No caso da atividade 7, a predominância da categoria AproxMH (quadro 26, página 140) associada à grande proporção de respostas do tipo presente talvez indique uma correlação entre a compreensão da moral da história e sua posição em relação às demais presentes no diagrama de fluxo (figuras 7, 8 e 9 nas páginas 77, 78 e 79).

O gráfico 2 apresenta o perfil da turma BR3E. Nessa turma, em praticamente todas as atividades, a proporção de respostas tipo passado ganha maior destaque. Isso pode indicar indiretamente que os alunos sentiram, ao longo do curso, a constante necessidade de complementação das atividades que haviam feito.

Nesse sentido, a atividade 2 se destaca negativamente quanto à sua aproximação do fluxo proposto, pois conta com mais de $60 \%$ das respostas do tipo passado. Quando se compara os resultados do histograma no quadro 21 (página 125) aos perfis da atividade 2 (gráficos 1,2 e 3 na página anterior), é possível 
perceber que a turma BR3E possui o maior proporção de respostas que se afastam da moral da história, ou seja, 3,8 vezes mais respostas $\operatorname{AfastMH}(a+b)$ do que $\operatorname{AproxMH}(\mathrm{c})$. A mesma relação aplicada às turmas BR3A e BR2E retornam as proporções 2,6 e 2,3 respectivamente. De forma simples isso significa que, para a atividade 2, a turma BR3E teve um desempenho ruim, a turma BR3A foi a intermediária e a BR2E foi a de melhor desempenho no quesito aproximação da moral da história. Quando se observa as proporções da $2^{a}$ etapa para a atividade 2, as mesmas turmas se posicionam da mesma forma, ou seja, a proporção de respostas tipo passado para a atividade 2 é maior para a BR3E, intermediária para a BR3A e menor para a BR2E como pode ser visto nos gráficos 1,2 e 3. De forma similar à observação feita para a atividade 7 , a atividade 2 reforça a hipótese de correlação existente entre as duas etapas do instrumento de fluxo.

A atividade 8 não apresenta nenhuma resposta do tipo passado. Esse resultado precisa ser observado com cuidado porque a turma BR3E possuía muito poucos alunos no dia da aplicação.

Uma característica levemente positiva presente no perfil da BR3E está na evolução das escolhas tipo presente ao longo do curso. Pode ser observado que sua participação se torna cada vez maior conforme as atividades avançam. Isso indica um pequeno movimento de aproximação da fluência da turma BR3E para o fluxo proposto.

O perfil da turma BR2E no gráfico 3 apresenta a melhor relação entre a fluência da turma e o fluxo pretendido no desenvolvimento da sequência didática. A proporção de respostas tipo passado tem valor aceitável no início da sequência vindo a diminuir gradativamente conforme a evolução do curso. Esse comportamento evolutivo não é acompanhado pelas respostas tipo presente e futuro, mas há maior predominância destas categorias em todas as atividades indicando uma percepção maior dos alunos quanto ao fluxo.

A atividade 5 é a que tem a maior proporção de respostas do tipo presente. Esse resultado talvez esteja relacionado à preparação feita pelo professor $D$ antes desta atividade. É importante ter em mente que a sequência didática é inovadora tanto para os alunos quanto para os professores. E, mesmo que os últimos tenham 
trabalhado diretamente na confecção das atividades, foram constantes as discussões diretamente relacionadas ao conteúdo relativístico. À atividade 5 , que conclui matematicamente o conceito de diferenciação temporal, foi depositado maior atenção quanto ao preparo feito pelo professor D. Em relato, o professor afirma:

\begin{abstract}
"Antes de começar o relato, gostaria de dizer que para executar essa atividade fiz o exercício várias vezes em casa numa folha de rascunho e posso dizer que treinei comigo mesmo para que quando eu explicasse, desse tudo certo." (Professor D, relato da atividade 5)
\end{abstract}

O professor preparou a aula para ser feita no laboratório da escola por que teria disponível duas lousas para apresentar todas as ideias simultaneamente. Com relação às passagens matemáticas ele afirma que

\footnotetext{
"Foi muito interessante, porque sentia que a cada passo na obtenção da equação, os alunos entendiam o que estava fazendo, porém quando já construída, percebi que havia utilizado as duas lousas e eles de certa forma ficaram "com medo" de ver aquilo tudo para chegar a um resultado bem pequeno." (Professor D, relato da atividade 5)
}

É provável que esse cuidado tenha influenciado na percepção dos alunos sobre o significado da atividade 5 em relação às opções disponibilizadas na $2^{\mathrm{a}}$ etapa da ficha, elevando assim a proporção de respostas tipo presente. Vale lembrar que a flexibilização feita nos critérios da etapa $1^{\mathrm{a}}$ não interferem na análise da $2^{\mathrm{a}}$ etapa.

Uma possibilidade interessante de analisar os dados é feita distribuindo-se os dados da dimensão de fluência, vindos da $2^{\mathrm{a}}$ etapa, entre as categorias AproxMH e AfastMH da $1^{\text {a }}$ etapa. Essa forma de organização permitiria que fossem observadas separadamente a fluência dos alunos cuja interface se aproxima do fluxo e a fluência dos alunos cuja interface se afasta dele. Entretanto, essa estratégia dilui os dados da dimensão de fluência em quantidades muito pouco representativas e impossibilita que a análise seja feita turma a turma.

A solução encontrada foi a reunião dos perfis individuais de cada turmas em 
um perfil geral. Esse movimento torna, por um lado, a análise insensível às diferenças entre os contextos de aplicação e entre os professores, mas por outro, permite uma representação geral do trabalho em equipe feito neste primeiro ciclo da pesquisa.

Para a criação do perfil unificado e dividido entre as categorias da dimensão de interface, alguns cuidados precisaram ser tomados. Algumas das fichas coletadas ao longo da pesquisa não foram completamente preenchidas e apresentaram respostas ou somente na $1^{\text {a }}$ etapa (dimensão de interface) ou somente na $2^{a}$ etapa (dimensão de fluência). O caso mais expressivo desta situação aconteceu com a turma BR2E na atividade 4 em que os todos os alunos responderam somente a $1^{\text {a }}$ etapa porque não tinham em mãos a $2^{\mathrm{a}}$ etapa do instrumento de fluxo. Em alguns poucos casos ocorreu o inverso, ou seja, somente a $2^{a}$ etapa foi respondida e não houve dados para a dimensão de interface. Essas situações podem ser ignoradas quando a análise de cada etapa é feita de forma individualizada. Entretanto, na análise conjunta entre as duas etapas esse subconjunto de fichas precisa ser subtraído.

Desta forma, os perfis produzidos pela união citada contabilizam somente as respostas em que ambas as etapas foram corretamente preenchidas. Excluem-se também as respostas da subcategoria Branc/Incorr por não serem representativas.
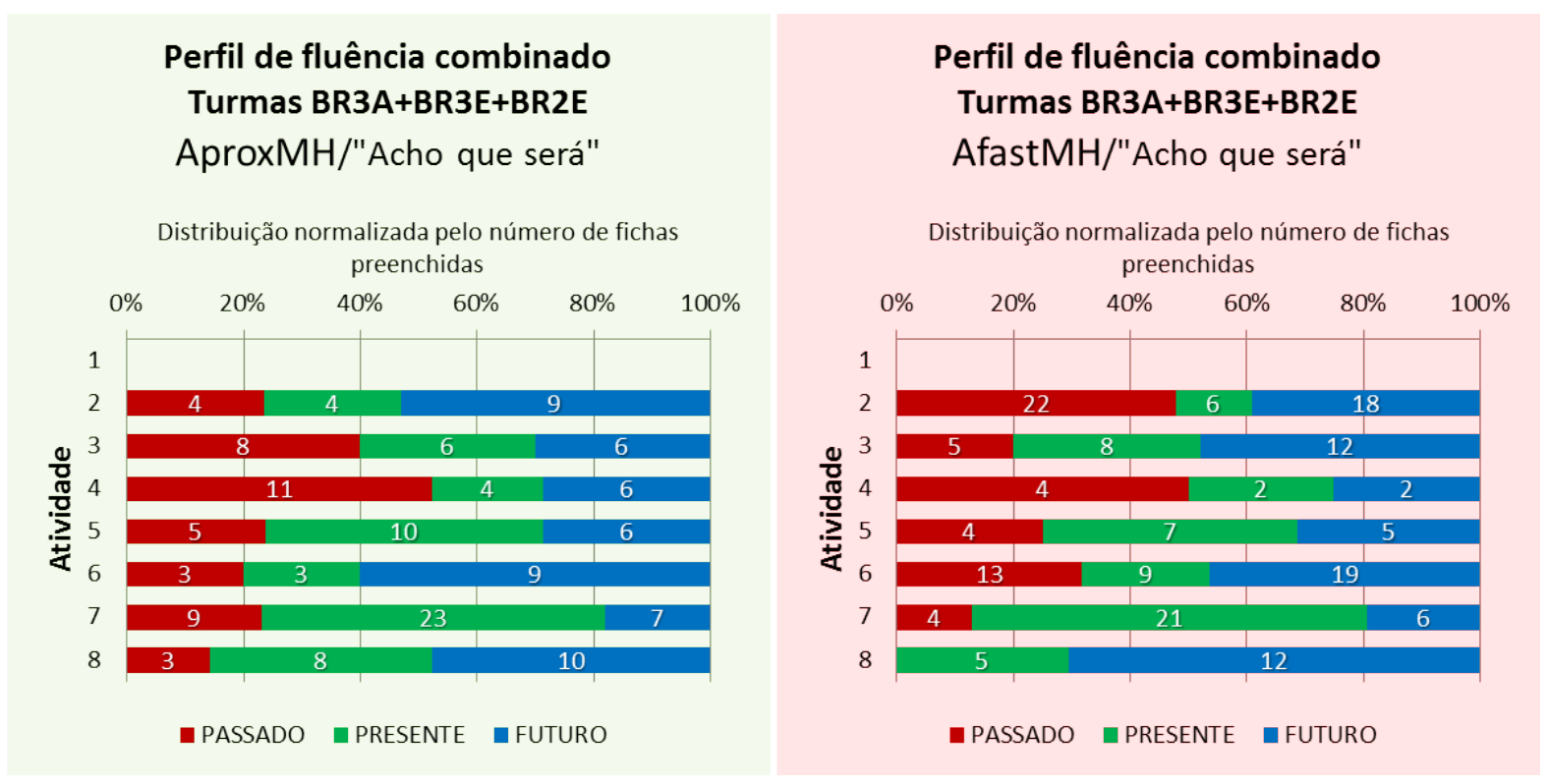

Gráfico 4: Perfis de fluência para AproxMH e AfastMH produzido pela combinação das de todas as turmas.

Quando se aplica uma sequência didática, não é incomum perceber que as 
primeiras atividades da sequência trazem consigo uma espécie de reinício das relações feitas em sala de aula. A reorganização acontece em vários níveis diferentes e exige uma série de readaptações relacionadas à renovação do contrato didático, ao reconhecimento das novas metodologias empregadas, ao esforço em compreender o contexto do novo conteúdo, entre outros. A perturbação causada pela sequência leva os alunos a criarem expectativas diversas sobre as direções que o curso poderia tomar. Após essa fase inicial, esperava-se que quanto mais avançados estivessem os alunos nas atividades da sequência, mais próximos seus perfis se aproximariam do fluxo devido à familiarização e reconhecimento proposta.

A análise dos perfis AproxMH e AfastMH, presentes no gráfico 4, permite afirmar que existe uma diminuição gradativa da proporção de respostas tipo passado com a evolução da sequência. Isso corrobora com a expectativa porque respostas tipo passado são aquelas que representam um retrocesso ou divergência da fluência em relação ao fluxo. Sua diminuição indica que os alunos compreenderam cada vez mais a sequenciação efetivamente planejada.

A grande dispersão dos dados torna difícil concluir a tendência das categorias presente e futuro. Desta forma, os dados das proporções foram organizados em forma de gráfico de dispersão e linha de tendência feita por regressão linear conforme pode ser visto no gráfico 5. É importante deixar claro que só podem ser analisadas tendências gerais nesses gráficos, porque a dispersão dos dados não permitiria definir qualquer aspecto do comportamento real dessa evolução. Ou seja, não se deve interpretar as linhas de tendência como funções matematicamente definíveis e que descrevam o comportamento dos dados devido à grande dispersão. 
Tendência de fluência

"acho que será"

BR3A+BR3E+BR2E (AproxMH)

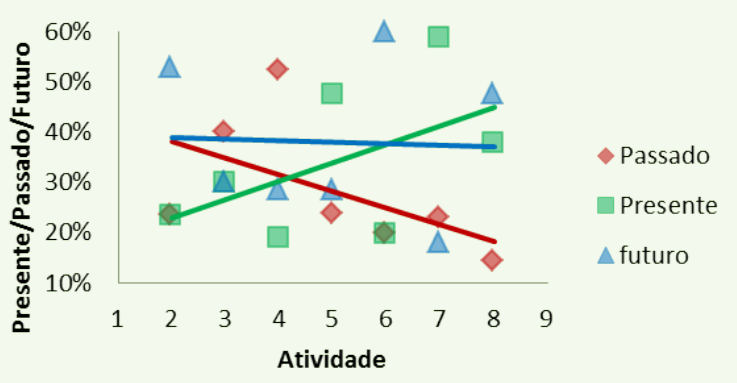

Tendência de fluência

"acho que será"

BR3A+BR3E+BR2E (AfastMH)

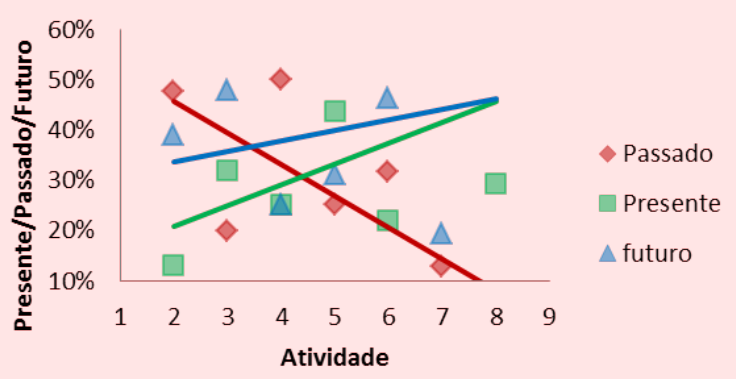

Gráfico 5: Tendência de fluência para AproxMH e AfastMH.

Tendo essa ressalva em mente, fica mais claro observar que o decréscimo das respostas tipo passado foi, na média, compensado por um acréscimo na categoria do tipo presente na categoria AproxMH. A proporção da categoria do tipo futuro se manteve sem alteração na média. Isso significa que proporcionalmente e de forma geral, as respostas tipo passado foram se tornando tipo presente ao longo do curso. A evolução para a categoria AfastMH é parecida, mas para os alunos que tiveram suas respostas se afastando da moral da história, tanto as respostas tipo presente quanto as respostas tipo futuro sofreram acréscimo conforme a evolução da sequência.

Essa descrição é importante no processo de validação do instrumento porque indica a existência do alinhamento médio para o fluxo conforme esperado.

O olhar mais atento ao conjunto de dados de cada atividade conduz a uma segunda análise importante. É razoável considerar que atividades com estruturas efetivamente baseadas em fluxo de alguma forma diferenciam o perfil das respostas que se aproximam da moral da história daquelas que se afastam dela. Isso porque as atividades que possuem o mesmo perfil tanto para os alunos que responderam AfastMH, quanto para aqueles que responderam AproxMH, são atividades que não conseguiram organizar didaticamente o conteúdo de modo a associar a moral da história ao fluxo em classe. Na situação oposta estão as atividades que demonstram uma diferenciação entre os perfis AproxMH e AfastMH, pois tais atividades possuem algum elemento ou organização que promove uma relação entre compreender a moral da história e perceber a existência de um fluxo.

De forma simples, se a atividade não promove diferença entre os que se 
aproximam e os que se afastam do fluxo, então essa atividade é ineficiente em tendenciar qualquer percepção da fluência. Isso não significa que os alunos não possam inferir corretamente o fluxo proposto. Uma atividade baseada em fluxo de boa qualidade, além de criar essa diferença, seria capaz de tendenciar o perfil para respostas tipo presente. Ao comparar os perfis no gráfico 4 da página 152, foi possível verificar que existem atividades nesses dois grupos.

No primeiro grupo estão as atividades que não aparentam possuir uma correlação entre as dimensões de interface e fluência, ou seja, seus perfis não exibem grandes diferenças entre as categorias AproxHM e AfastMH. Enquadram-se nesse grupo os perfis das atividades 4, 5 e 7. O segundo grupo é formado pelos perfis que indicam alguma correlação entre as duas dimensões. Nesses casos, 0 perfil das respostas AproxMH é visivelmente diferente do perfil das respostas AfastMH. Estão enquadradas nesse grupo as atividades 2, 3, 6 e 8.

Essa forma de analisar o gráfico 5 possibilitou guiar a atenção para a seguinte questão: como e quais elementos transversais às atividades promovem corretamente a moral da história para fazê-la interferir no perfil de fluência? De modo algum o perfil indicaria esses elementos, mas tendo em vista o acompanhamento aproximado no processo de desenvolvimento, talvez seja possível inferi-los.

Quando se observa a sequência como um todo é possível distinguir dois grandes blocos que se repetem. As três primeiras atividades são introdutórias e problematizam a diferenciação do tempo. As atividades 4 e 5 estruturam o problema para uma representação matemática finalizando o bloco. A atividade 6 inicia o segundo bloco introduzindo e contextualizando do paradoxo dos gêmeos, as atividades 7, 8 e 9 fazem o mesmo movimento das atividades 4 e 5 ao estruturarem matematicamente o problema do paradoxo.

As atividades 4, 5 e 7, que não trazem diferenças entre as categorias AproxMH e AfastMH, são todas relacionadas à estruturação matemática. As atividades 4 e 5 são complementares e destinadas à criação do modelo físico associado à diferenciação do tempo. A atividade 4 promove um movimento de abstração do fenômeno por meio do raciocínio relativístico gradualmente sistematizado no material. A atividade 5 procura representar e articular matematicamente o fenômeno de diferenciação. A atividade 7 também intenciona trabalhar a representação matemática e se assemelha à função da atividade 4 quando aborda a noção de evento. 
Essa característica matemática comum a essas atividades talvez seja uma primeira pista sobre esse não relacionamento entre o reconhecimento da moral da história e o perfil de fluência.

Uma segunda pista aparentemente esteja associada à forma como foram construídas as atividades. As atividades 5 e 7 tiveram origem no primeiro período e tiveram seus esboços iniciais vindos da instância de pesquisa conforme pode ser visto no quadro 2 (4.1.1 Primeiro período, página 42). A atividade 4 não se enquadra nessa situação, entretanto, quando da divisão de tarefas entre pesquisadores e professores no início do desenvolvimento, o pesquisador teve maior influência na construção desta atividade por ser considerada de maior dificuldade conceitual. As atividade 9 se enquadra nessa situação, mas não possui fluxo associado por ser a última atividade.

Talvez essa influência da instância de pesquisa no desenvolvimento seja um denominador comum associado à desconexão entre a dimensão de interface e a dimensão de fluência, seja de forma intencional como no caso das atividade 5, 7 e 9, seja de forma não intencional como na atividade 4.

Um obstáculo didático-pedagógico importante no desenvolvimento da atividade 4 está associado ao embate presente entre seu conteúdo conceitual e o conteúdo procedimental. O conceito de referencial inercial explica que para dois sistemas físicos com velocidades constantes e diferentes as leis físicas são invariantes. Entretanto, ao tratar problemas didaticamente propostos desta natureza, é comum que o principal aspecto analisado esteja associado não aos elementos invariantes, mas sim aos elementos que são relativos aos referenciais. Procura-se, por exemplo, antever onde alguma coisa acontece, a velocidade relativa de um objeto em relação a um ou outro ou ainda sua energia.

Nas atividade 4 e 5, por exemplo, os referenciais do R-Luz e do "skatista" são conceitualmente equivalentes, mas quando se começa a tratar as questões, o foco procedimental torna o referencial do R-Luz como o referencial próprio e o do skatista como um diferente. De fato o referencial próprio possui características que o definem, como por exemplo, a de que possui a menor medida tempo entre dois eventos quando comparada com as medidas de qualquer outro referencial. Mas esse "privilégio" não está relacionado à equivalência dos referenciais. Ele se relaciona com a montagem específica desse problema. Mas, no final das contas, o aluno compreende que existe um referencial "parado" e um referencial em 
"movimento" na hora de resolver o problema.

A atividade 6 segue com a mesma situação incômoda pois apresenta um dos irmãos no referencial da Terra e outro no referencial "em movimento" do foguete. A situação se torna mais complicada porque há uma comparação entre as perspectivas dos dois gêmeos. Isso implica em compreender duas situações distintas simultaneamente. Na primeira o gerador de eventos é o gêmeo no foguete, na segunda, o gerador de eventos é o gêmeo que está na Terra.

Após estudos sobre os eventos e pontos de vista na atividade 7 e intervalos relativísticos na atividade 8 , os alunos revisitam o problema dos gêmeos novamente. $\mathrm{Na}$ situação apresentada, é indica que um dos gêmeos necessariamente precisa encontrar o outro para que a comparação seja feita. Essa necessidade do encontro exige que o gêmeo viajante freie, pare e retorne até encontrar o primeiro gêmeo. $A$ solução final aparece analisando-se o momento em que gêmeo do foguete resolve retornar. Uma situação assimétrica surge e aquele paradoxo onde ambos os gêmeos estavam ficando mais jovens não faz mais sentido pois um dos gêmeos não esteve o tempo todo num referencial inercial.

A sutileza do obstáculo está nas compreensões truncadas que se acumulam no caminho. Primeiro, os alunos são levados a compreender que referenciais são diferentes com base na forma de resolução dos problemas, especialmente o conteúdo procedimental relacionado ao uso do referencial próprio nas atividade $4 \mathrm{e}$ 5. Depois eles são levados a compreender que os referenciais são equivalentes com base no princípio da relatividade, ou seja, pelo conteúdo conceitual na atividade 6 . Finalmente, os alunos são levados a compreender que os referenciais são novamente diferentes, porque um dos gêmeos não está a todo momento num referencial inercial na atividade 9.

Este vai e vem implícito ao conceito de referenciais aparentemente não foi compreendido por vários alunos e talvez explique a existência de um grande grupo de respostas inconsistentes encontradas ao longo das atividades.

O planejamento adequado das aplicações da sequência didática de RR segundo a proposta desta sequência solicita que o professor sempre tenha em mente o diagrama de fluxo. Antes de cada atividade, espera-se que ele observe o conector vem antes e o conector que vem depois da respectiva moral da história 
para compreender e direcionar a atividade para o momento didático em que se encontra. Entretanto, a primeira atividade no diagrama de fluxo não possui um dos conectores associado porque não há atividade que a preceda. O mesmo ocorre com a última atividade, pois o diagrama de fluxo deixa a última moral da história solta, sem o conector final.

A primeira vista isso não é um problema porque espera-se que o professor simplesmente inicie a primeira atividade e se preocupe apenas com a conexão seguinte, na atividade final, os objetivos gerais da sequência teriam sido alcançados e tudo terminaria bem. Entretanto, durante uma conversa com o professor $\mathrm{E}$, que não participou da elaboração das atividades, e posteriormente em outras situações com os professores A e D, foi observada a busca de informações ligadas ao início e ao fim da sequência. Qual seria a primeira tendência a ser dada no curso? Tal busca, sutil e dispersa nas conversas, aparentemente não estava associada ao conteúdo ou ao material, mas sim sobre representação no diagrama de fluxo.

Certamente o material apresenta seus objetivos gerais. Especificamente sobre a atividade 1, a moral da história indica a existência de vários tipos de tempo, mas os estudos serão sobre o tempo físico. A pergunta que se faz é: qual pergunta a atividade 1 deverá responder quando se observa o diagrama de fluxo? Nesse sentido, talvez seja interessante desenvolver um conector inicial com função introdutória.

A última atividade aparentemente sofre mais com essa lacuna, pois houve consenso de todos os professores, inclusive os alemães, de que a sequência precisaria promover um sentimento mais excitante no final. Ou que faltava algum brilho na última atividade. Quando se observa o histograma do quadro 28, pode-se atribuir tal falha na finalização à superposição de algumas hipóteses.

Aparentemente não houve correspondência das respostas dos alunos à moral da história, ou seja, a atividade não conseguiu promover situações didáticas suficientes para se alcançar o objetivo proposto, mas além disso a própria atividade poderia ser deficiente em apresentar uma finalização empolgante.

Seria melhor se a última atividade se expandisse para além do âmbito didático da própria sequência de RR. Apresentando uma sistematização dos assuntos tratados e conectando-os à nova visão do mundo externo que pretendeu desenvolver. Mas, como fazer isso de fato durante o processo de desenvolvimento se os objetivos da atividade 9 (veja o quadro 19 na página 105) foram produzidos 
com vistas numa moral da história que se restringe ao objetivo-obstáculo que fora tratado na sequência?

Talvez esse aspecto na atividade 1 não fora tão expressivo porque aquela moral da história possui uma ideia da conexão externa pretendida quando diz que "existem várias formas de entender o tempo" (figura 7, 8 e 9 nas páginas 77, 78 e 79). A moral da história da atividade 9 não diz nada sobre a necessidade de alguma conexão com o ambiente didático externo ou ao mundo de forma geral.

Toda essa situação parece indicar que a criação do diagrama de fluxo precisa ser complementado tanto com conectores introdutórias como com indicações finalizadoras para que durante o desenvolvimento da atividade, o respectivo fluxo tenha melhor adequação às condições didáticas do ambiente externo. 


\section{CONSIDERAÇÕES FINAIS}

A pesquisa se propõe produzir conhecimentos sobre a percepção de fluência que os alunos desenvolveriam sobre o encadeamento das atividades presentes em uma sequência didática. Utilizando a metodologia DBR, uma sequência sobre Relatividade Restrita foi criada com a finalidade de produzir situações favoráveis ao reconhecimento dessa fluência. $O$ protoprincípio fluxo didático foi desenvolvido e conceitualizado como parâmetro central na criação deste tipo de pesquisa. O instrumento de fluxo foi desenvolvido como a forma de se coletar dados para análise. E uma pesquisa auxiliar permitiu verificar aspectos específicos sobre a concepção de evento. Um dos principais compromissos da pesquisa foi creditar importância em tornar as intenções didáticas dos professores reconhecíveis pelos alunos presentes no centro do processo didático. A aplicação da DBR garantiu a existência dessa intencionalidade no material didático e nas atitudes dos professores viabilizando a produção de dados sobre a fluência percebida na instância de alunos.

$O$ instrumento de fluxo aplicado à sequência se mostrou eficiente em apresentar um conjunto de informações locais e instantâneas sobre a conexão entre as atividades. A categoria de interface apresentou informações relevantes sobre a compreensão que os alunos tiveram sobre a moral da história de cada atividade. A dimensão de fluência tratada turma a turma mostra apenas tendências da fluência percebida pelos alunos devido à pequena quantidade de dados. Entretanto o tratamento coletivo das turmas se mostrou mais interessante para verificar a evolução da fluência dos alunos em relação ao fluxo proposto. Finalmente a correlação entre as duas dimensões permitiu identificar as atividades capazes de promover compreensão do fluxo daquelas que não promoveram. Deste modo, foi possível verificar quão próximas ficaram a fluência percebida pelos alunos do fluxo pretendido pelos desenvolvedores.

É interessante pensar no instrumento de fluxo como um primeiro passo exploratório na instrumentalização de pesquisadores que pretendam fazê-lo evoluir. A evolução de aspectos relacionados à fidedignidade do instrumento, especialmente no preparo das questões dissertativas da $1^{\text {a }}$ etapa e nas alternativas que 
representam fluxos possíveis em direção ao passado ou ao futuro na $2^{\mathrm{a}}$ etapa de cada atividade, seria a primeira sugestão para a continuidade deste trabalho.

Uma outra proposta interessante para melhorar a análise seria incluir ferramentas estatísticas para determinar a qualidade das tendências mostradas nos perfis de fluência e nas regressões lineares apresentadas no gráfico 5 . Informações sobre a representatividade dos perfis de fluência trariam, aos grupos de desenvolvimento, melhores condições de tomarem decisões sobre a modificação, exclusão ou criação de atividades.

A sequência de ensino-aprendizagem foi ferramenta inspiradora aos professores que, no limiar do tradicional e do inovador, se arriscam a produzir novos conhecimentos em sala de aula. A ideia da sequência foi criar algo não chocante, factível e que guiasse o professor iniciante em direção à busca por inovações. Os relatos que possuímos de professores externos ao desenvolvimento se restringem às aplicações internacionais. É possível afirmar que a adesão desses professores à proposta e a compreensão sobre a direção em que o fluxo didático apontava indica a boa capacidade que o diagrama de fluxo e o material da sequência possui em transmitir informações essenciais à aplicação. Um minicurso foi ministrado no XX SNEF (2013) com base na sequência de RR. Na ocasião diversos professores tiveram uma boa primeira impressão sobre a aplicabilidade da sequência. Num questionário simples passado ao final do curso foi possível verificar afirmações do tipo “(...) eu sabia que tinha dedo de professor nesse trabalho". Esse reconhecimento sobre proximidade que o material didático possuía com a prática do professor em sala de aula mostra que a sequência conseguira agregar aspectos identitários próprios do fazer escolar durante o processo de produção coletiva.

A utilização do diagrama de fluxo como uma condição de contorno para a produção da sequência didática se mostrou eficaz em organizar o desenvolvimento da sequência e em representar o fluxo de forma simples. Ele conseguiu reunir as diversas perspectivas vindas dos diversos integrantes para formar o objeto que efetivamente foi estudado.

As atividades quando observadas de forma fragmentada foram diversas vezes, ao longo das aplicações, consideradas um sucesso pelos professores e pelo pesquisador. De fato, a produção e aplicação da sequência promoveu uma série de conhecimentos a todas as instâncias. Entretanto é necessário se ater aos resultados apresentados pela pesquisa. Quando se verifica a quantidade de alunos que se 
alinham com o fluxo da sequência, é possível verificar que um pouco mais de $50 \%$ das respostas não se alinharam ao fluxo desenvolvido durante a criação da sequência. Esse resultado expressivo indica a necessidade de preparo frente à indeterminação neste tipo de situação.

A terceira questão da Pesquisa Auxiliar é de interesse específico ao ensino de RR. Ela conta com 4 categorias bem definidas e simples sobre a percepção que o aluno possui inicialmente sobre o conceito de evento. As categorias foram desenvolvidas com base numa perspectiva teórica que considera duas opções: ou os fenômenos dependem da observação para existirem ou não. Um dos resultados expressivos é a existência de uma grande parcela dispersa ( $40 \%$ de respostas), ou seja, quantidade expressiva de alunos quando questionados duas vezes sobre 0 significado de evento, justifica sua escolha de modo incoerentemente com a expectativa da pesquisa.

Com vistas na construção de um pensamento científico coerente, seria interessante que o público escolar considerasse os fenômenos como não dependentes da presença ou vontade humana para os casos apresentados. Entretanto seria essa perspectiva condizente com a realidade brasileira? Seria a disciplina de Física, não os conteúdos que a compõe, mas a visão científica promovida por ela contextualizada ao longo dos anos escolares? A Pesquisa Auxiliar permitiu traçar perfis de respostas que diferenciaram os contextos escolares. Quando se observa os resultados, infere-se que o pensamento científico não foi bem apresentado nas escolas brasileiras pesquisadas ao passo que é melhor reconhecida pelos alunos das escolas alemãs.

A pesquisa parte da hipótese de que exista um saber construído no âmbito do saber ensinado associado à compreensão da fluência de uma sequência didática. Essa hipótese foi colocada no centro do processo de desenvolvimento junto ao objetivo-obstáculo sobre o absolutismo do tempo. Esse movimento permitiu o controle dos parâmetros que definiram a construção do instrumento de fluxo de forma clara.

A validade da pesquisa é consideravelmente elevada devido à colaboração entre professores e pesquisadores. A criação da sequência didática ocorreu de forma a incorporar a experiências práticas dos professores e seu emprego foi feito em contextos genuínos de sala de aula.

Tanto os instrumentos de pesquisa quanto a própria sequência didática 
foram pensadas para permitirem aprimoramento. A continuidade da pesquisa foi garantida pela exposição detalhada da forma como cada representação e parâmetro foi criado. Neste sentido destacam-se o conjunto de hipóteses associadas ao fluxo e sua conceitualização, a forma como o diagrama de fluxo se torna consoante com a perspectiva coletiva, o modo empregado no instrumento de fluxo para amarrar o diagrama de fluxo à fluência percebida pelos alunos no contexto de aplicação e à apresentação da sequência em si como o objeto materializador da intenção didática modulada pelo protoprincípio de fluxo didático.

Esta preocupação em cumprir com todos os quesitos metodológicos previstos pela DBR vem da intenção do pesquisador em reconhecer os parâmetros que efetivamente influenciam a construção de sequências didáticas em pesquisas similares. Deste modo, foi possível criar um conjunto de dados e conclusões passíveis de serem melhoradas, testadas ou refutadas. 


\section{REFERÊNCIAS ${ }^{29}$}

ARRUDA, S. M., \& VILLANI, A. Sobre as Origens da Relatividade Especial: Relações entre Quanta e Relatividade em 1905. Caderno Catarinense de Ensino de Física, vol. 13(1), p. 32-47, 1996.

ASTOLFI J. P. El Trabajo Didáctico de Los Obstáculos, en El Corazón de Los Aprendizajes Científicos. Enseñanza de las Ciencias, vol. 12, $n^{\circ} 2$ : p. 206-216, 1994.

BACHELARD, G. A Formação do Espírito Científico: Contribuição para psicanálise do conhecimento. Tradução Abreu, E. S. Rio de Janeiro: Contraponto, 1938.

BASSALO, J. M. F. Aspectos Históricos das Bases Conceituais das Relatividades. Revista Brasileira de Ensino de Física, vol. 19(2), p. 180-188, 1997

BECHARA, M. J. et. al. Física 4 Notas de aula. São Paulo: Instituto de Física da Universidade de São Paulo, 2007.

BRASIL. Lei № 9.394, de 20 de dezembro de 1996. Lei de Diretrizes e Bases da Educação Nacional. Diário Oficial da União, Brasília, DF,23 dez. 1996. Disponível em: <http://www.planalto.gov.br/ccivil_03/leis/19394.htm>. Acesso em: 20 junho 2014.

. Parâmetro Curriculares Nacionais para o Ensino Médio. Ministério da Educação/Secretaria da Educação Média e Tecnológica, Brasília, 1999.

PCN+ Ensino Médio: Orientações Educacionais Complementares aos Parâmetros Curriculares Nacionais para o Ensino Médio. Ciências da Natureza, Matemática e suas tecnologias. Ministério da Educação/Secretaria da Educação Média e Tecnológica, Brasília, 2002.

BROCKINGTON, G. A Realidade Escondida: A Dualidade Onda-Partícula para Estudantes do Ensino Médio. Dissertação de Mestrado. Universidade de São Paulo, São Paulo, 2005.

BROWN, A. L. Design Experiments: Theoretical and Methodological Challenges in Creating Complex Interventions in Classroom Settings. The Journal of the Learning Sciences, vol. 2, $n^{\circ} 2$, p. 141-17, 1992.]

BUTY, C.; TIBERGHEIN, A.; MARÉCHAL, J. F. L. Learning Hypotheses and an Associated Tool to Design and to Analyse Teaching-Learning Sequences. International Journal of Science Education. vol. 26(5), p. 579-604, 2004. 
CARVAlHO, A. M. P.; GIL-PÉREZ, D. Formação de Professores de Ciências. 8. ed. São Paulo: Cortez, 2006.

CHEVALLARD, Y. La Transposicion Didactica: Del Saber Sabio al Saber Enseñado. La Pensée Sauvage, Argentina, 1991.

COLL, C. et al. Os conteúdos na Reforma: ensino e aprendizagem de conceitos, procedimentos e atitudes. Porto Alegre: Artmed, 2000.

COLLINS, A. Toward a Design Science of Education: technical report $n^{0} 1$. New York: Center of technology in education, 1990. Disponível em: $<$ HTTP://ERIC.ED.GOV/?Q=COLLINS\%2C+ALLAN\&PG=2\&ID=ED357733>. Acesso em: 14 May 2014.

COLLINS, A.; JOSEPH, D.; BIELACZYC, K. Design Research: Theoretical and Methodological Issues. The Journal of Learning Sciences, vol. 13(1), p. 15-42, 2004.

DBR COLLECTIVE. Design-Based Research: An Emergin Paradigm for Educational Inquiry. Educational Researcher, vol. 32(1), p. 5-8, 2003.

EDWIN F. T.; WHEELER, J. A. Spacetime Physics. W. H. Freeman and Company, San Francisco, 1963.

ESTADO DE SÃO PAULO. Proposta Curricular do Estado de São Paulo: Física. Maria Inês Fini (coord). Secretaria de Estado da Educação, São Paulo, 2008.

FERRER, A. Concepções de Estudantes Acerca do Conceito de Tempo: Uma Análise à Luz da Epistemologia de Gaston Bachelard. Tese de doutorado. Universidade de São Paulo, São Paulo, 2004.

FERRER, A. P. M.; ZANETIC, J. O Tempo na Mecânica: de Coadjuvante a Protagonista. Caderno Brasileiro de Ensino de Física, vol.19(2), p. 149-175, 2002.

HERNÁNDEZ, M.I.; PINTÓ, R. The process of Iterative Development on a Teaching/Learning Sequence on Acoustic Properties of Material. In: Psillos, D.; Kariotoglou, P. (Eds.). Interative Design of Teaching-Learning Sequences: Introducing the Science of Materials in European Schools, Springer Editorial, in press.

KARAM, R. A. S. Relatividade Restrita no Início do Ensino Médio: Elaboração e Análise de uma Proposta. Dissertação de mestrado. Universidade Federal de Santa Catarina. Florianópolis, 2005.

KARAM, R. A. S.; CRUZ, S. M. S. C. DE S.; COIMBRA, D. Experiência de Michelson-Morley no Ensino Médio: Prerrogativa e Possibilidades. In: XVII SIMPÓSIO NACIONAL DE ENSINO DE FÍSICA, 2007, São Luis, Maranhão. Anais eletrônicos. São Paulo: SBF, 2007. Disponível em: <http://www.sbf1.sbfisica.org.br/eventos/snef/xvii/atas/>. Acesso em: 22 de Julho de 
2014.

KARAM, R. A. S.; CRUZ, S. M. S. C. DE S.; COIMBRA, D. Tempo Relativístico no Ensino Médio. Revista Brasileira de Ensino de Física, vol. 28, n 3, p. 373-386, 2006.

LANDAU, L.; RUMER, Y. O que é a teoria da relatividade. Tradução: Giorio Moscati. Brasil: Ed. Hemus, 2004.

LIJNSE, P. L. Didactical Structures as An Outicome of Research on TeachingLearning Sequences? International Journal of Science Education, vol. 26:5, p. 537-554, 2004.

LIJNSE, P. L. "Developmental Research" As a Way to an Empirically Based "Didactical Structure" of Science. Science Education, vol. 79(2), p. 189-199, 1995.

MÉHEUT, M.; PSILLOS, D. Teaching-Learning Sequences: Aims and Tools for Science Education Research. International Journal of Science Education, vol. 26(5), p. 515-535, 2004.

NICOLAU, J. L.; BROCKINGTON, G.; SASSERON, L. H. Formação Continua de Professores para Abordagem de tópicos de Relatividade no Ensino Médio: Saberes Docentes dos Implementadores. Experiências em Ensino de Ciências, vol. 6(2), p. 96-106, 2011.

OFUGI, D. A Inserção da Teoria da Relatividade no Ensino Médio. Dissertação de Mestrado. Universidade Federal de Santa Catarina. Florianópolis, 2001.

OGBORN, J. Introducing Relativity: Less May Be More. Physics Education, vol. 40, p. $213-222,2005$.

OSTERMANN, F.; MOREIRA, M. A. Uma Revisão Bibliográfica Sobre a Área de Pesquisa "Física Moderna e Contemporânea no Ensino Médio". Investigações em Ensino de Ciências, vol. 5(1), p. 23-48, 2000.

PEREIRA, A. P.; OSTERMANN, F. Sobre o Ensino de Física Moderna e Contemporânea: uma revisão da produção acadêmica recente. Investigações em Ensino de Ciências, vol. 14(3), p.393-420, 2009.

PIETROCOLA, M. A. Mathematics as a Structural Language of Physics Thought. In: Matilde Vicentini and Elena Sassi (Org.). Connecting Research in Physics Education with Teacher Education. 2nd ed. New Delhi: Angus \& Grapher Publishers, 2010, vol. 2, p. 35-48.

- Transposição da Física Moderna e Contemporânea para o Ensino Médio: Superando Obstáculos Epistemológicos e Didático-Pedagógicos. In: Regina Borges (Org.). Propostas Interativas na Educação Científica e Tecnológica. Porto Alegre: EDUC, p. 159-180, 2008.

PORTO, C. M.; PORTO, M. B. D. S. M. Uma Visão do Espaço na Mecânica 
Newtoniana e na Teoria da Relatividade de Einstein. Revista Brasileira de Ensino de Física, vol. 30(1), p. 1-8, 2008.

RAMOS, P. AMBIENTE VIRTUAL VIVÊNCIAS: análise do processo de desenvolvimento na perspectiva da pesquisa baseada em design. Tese de Doutorado. Universidade Federal do Rio de Janeiro, Rio de Janeiro, 2010.

RUBY, L. Teaching Special Relativity Without Calculus. The Physics Teacher, vol. 47, p. 231-232, 2009.

SIQUEIRA, M. R. DA P. Do Visível ao Indivisível: Uma proposta de Física de Partículas Elementares para o Ensino Médio. Dissertação de Mestrado. Universidade de São Paulo. São Paulo, 2006.

TERRAZZAN, E. A. A Inserção da Física Moderna e Contemporânea no Ensino de Física na Escola de $2^{\circ}$ Grau. Caderno Catarinense de Ensino de Física, vol..9(3), p. 209-214,1992.

VIENNOT, L. et al. Designing Strategies and Tools for Teacher Training: The Role of Critical Details, Examples in Optics. Science Education, v. 89(1), p. 13-27, 2005.

VIENNOT, L. Physics Education Research: Inseparable Contents and Methods - The Part Played by Critical Details. In: Maija Ahtee, Ole Bjorkqvist, Erkki Pehkonen, and Virpi Vatanen (Org.). Research on Mathematics and Science Education: From Beliefs to Cognition from Problem Solving to Understanding, Institute for Educational Research: Finland, 2001. p.90-100.

WEITZMAN, E. A. Software and Qualitative Research. In: Norman K. Denzin and Yvonna S. Lincoln (Org.). The handbook of qualitative research. 2nd. Ed.Thousand Oaks, CA: Sage, 2000, p. 803-820.

ZANETIC, J. Física Também é Cultura. Tese de Doutorado. Universidade de São Paulo, São Paulo, 1989. 
UNIVERSIDADE DE SÃO PAULO

INTITUTO DE FÍSICA, INSTITUTO DE QUÍMICA, INSTITUTO DE

BIOCIÊNCIAS E FACULDADE DE EDUCAÇÃO

JORGE LUIZ NICOLAU JUNIOR

Estrutura didática baseada em Fluxo: Relatividade Restrita para o Ensino Médio

$$
\text { v. } 2
$$

São Paulo 


\title{
JORGE LUIZ NICOLAU JUNIOR
}

\section{Estrutura didática baseada em Fluxo: Relatividade Restrita para o Ensino Médio}

\author{
em dois volumes \\ v. 2
}

Dissertação de mestrado apresentada ao Instituto de Física, ao Instituto de

Química, ao Instituto de Biociências e à Faculdade de Educação da Universidade de São Paulo para a obtenção do título de Mestre em Ensino de Ciências.

Área de Concentração: Ensino de Física

Orientador: Prof. Dr. Maurício Pietrocola Pinto de Oliveira.

São Paulo 


\section{SUMÁRIO}

DEDICATÓRIA

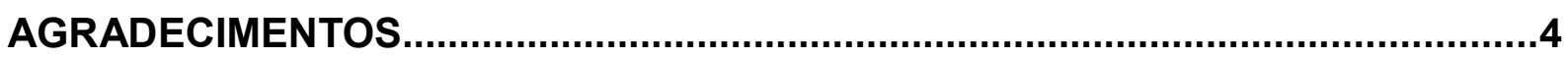

RESUMO

ABSTRACT

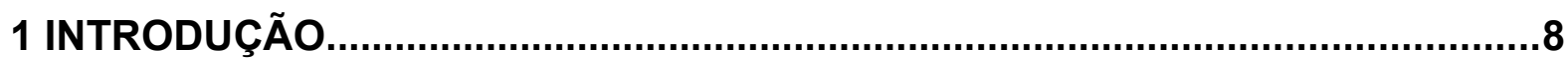

2 A RELATIVIDADE RESTRITA NA ESCOLA .....................................................

3 REFERENCIAIS TEÓRICO-METODOLÓGICOS................................................15

3.1 A TRANSPOSIÇÃO DIDÁTICA COMO PANO DE FUNDO …….....................15

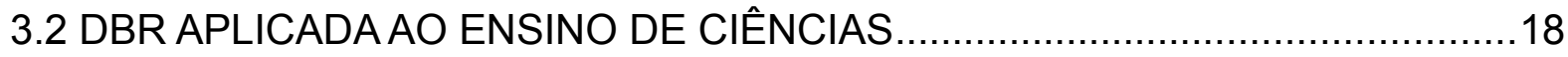

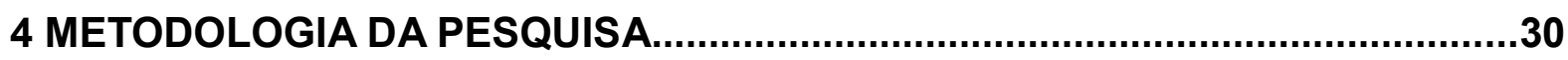

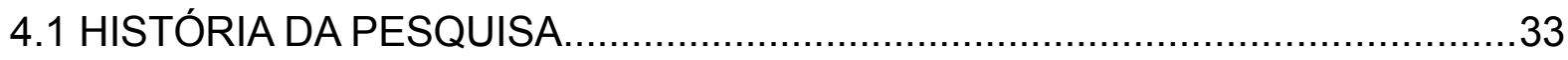

4.2 PESQUISA AUXILIAR

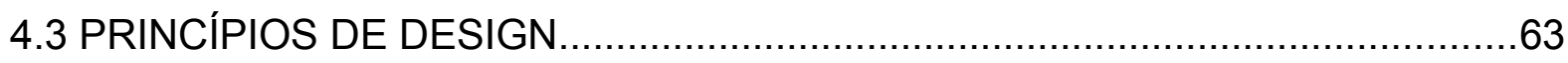

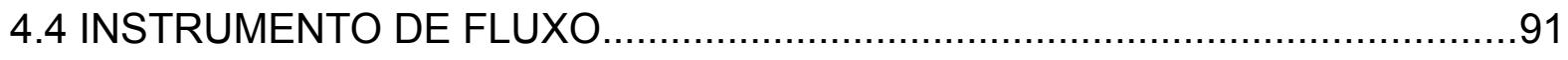

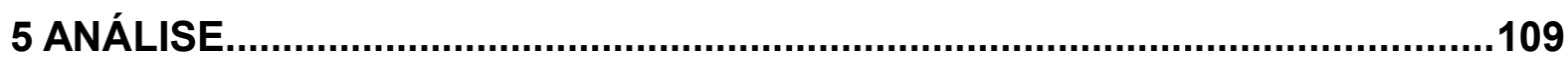

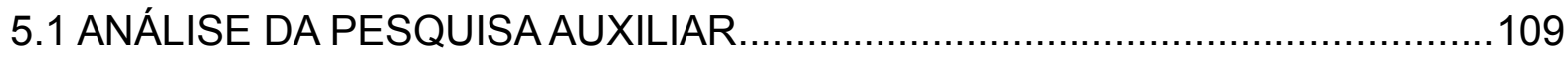

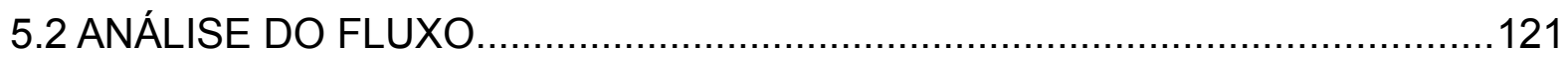

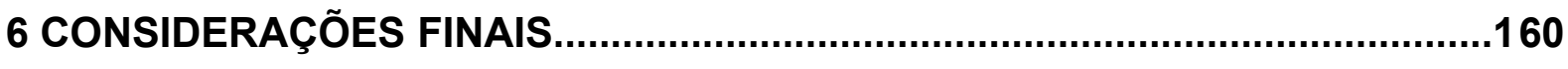

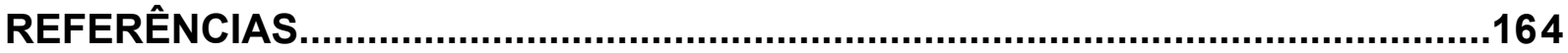

ANEXO 1 - SISTEMA EDUCACIONAL ALEMÃO..............................................170

ANEXO2 - MODELO DE FICHA DA PESQUISA AUXILIAR.................................176

ANEXO 3 - SEQUÊNCIA DIDÁTICA SOBRE RELATIVIDADE RESTRITA............180 


\section{ANEXO 1 - SISTEMA EDUCACIONAL ALEMÃO}

Como a pesquisa auxiliar possui dados produzidos em contexto estrangeiro, apresentam-se abaixo algumas das principais características do sistema educacional alemão visando a melhor compreensão da análise e conclusões futuras. A maior fonte de pesquisa utilizada aqui é a Eurydice ${ }^{30}$, um site de informações e análises do sistema educacional europeu criado pela Comissão Europeia em 1980 o qual auxilia a Comunidade Europeia na tomada de suas decisões educacionais.

A estrutura educacional alemã constituída a partir do ensino primário até o superior é condicionada pelo governo federal, mas de acordo com a lei básica, a administração e legislação são primeiramente de responsabilidade das Länder (o que equivale a uma unidade federativa no Brasil). A divisão administrativa se organiza em Ministério da Educação da Länder, Assuntos culturais e Ciência e em autoridades regionais. Os jardins de infância são regulamentados por ministérios sociais mais relacionados às questões de saúde e bem do que a questões educacionais, eles são mantidos majoritariamente por associações religiosas ou comunitárias, mas não deixam de receber recursos públicos.

O sistema privado de escolas, que abriga aproximadamente $10 \%$ dos alunos alemães, podem receber recursos do Estado com valores padronizados pela Länder a qual pertence de modo que se procura manter os padrões educacionais nacionais aplicados da mesma forma no o setor privado e no público.

Aproximadamente $90 \%$ dos alunos de ensino médio estão no setor público (general education and vocational education). Com alguma diferença entre as Länder, a escola é normalmente obrigatória dos 6 aos 15 de forma integral e dos 15 aos 18 anos obrigatória em meio período. O período de aulas vai de Agosto até Julho variando de 188 dias por ano a 208 dias para escolas com aulas aos sábados. O número de aulas semanais varia de 20-29 no primário e de 28-32 aulas no secundário, todas com período de $45 \mathrm{~min}$, sendo que na maioria das escolas inicia suas atividade no período da manhã.

As crianças alemãs entre 3 e 6 anos podem entrar no jardim da infância. 
Interessante observar que aqueles que chegarem aos 6 anos e não estiverem preparados para a escola primária podem requerer paralelamente a Schulkindergärden ou a Vorklassen, uma sequência paralela de acompanhamento que inicia um ano antes do ingresso no primário e pode se estender até um ano depois (aproximadamente dos 5 aos 7 anos) visando adequar as crianças à nova realidade. Os professores são treinados no upper secondary level de modo semelhante ao antigo magistério brasileiro.

Estruturalmente, o ensino primário guarda alguma semelhança antigo sistema brasileiro, pois ocorre em 4 anos tendo um professor para todas as matérias. Como será mostrado adiante o lower secondary school, equivalente ao nosso ensino básico II, possui diversos caminhos escolares distintos a serem seguidos. $O$ ingresso em um vertente ou outra depende do desempenho escolar do aluno e pais. De modo geral, um levantamento feito pela escola guia na decisão quanto ao tipo de escola que o aluno irá frequentar com vistas na futura carreira escolar e a decisão final é dada ou pelos pais, pela escola ou pela autoridade que supervisiona a escola, dependendo da Länder.

Após a escolha guiada da escola a ser cursada, os alunos vão para a lower secondary school. Entretanto, ainda recebem por dois anos orientações sobre os diferentes tipos de modalidade escolar que poderiam cursar permitindo aos alunos alguma autonomia para tomar suas decisões na carreira escolar com base no seu próprio currículo.

A diversidade de programas pode ser vista no quadro 29 é muito grande e há particularidades dependendo da Länder. Entretanto, a de forma geral o aluno segue a carreira escolar escolhida em uma das 4 opções abaixo:

Gymnasium: é um programa com caráter propedêutico que visa formação superior em ciências;

Realschule: é um programa intermediário que articula a prática e a teoria. Tem caráter técnico e o acesso voltado ao ensino superior profissionalizante.

Hauptschule: é um programa que foca no fazer prático. Ao final do curso, os alunos podem cursar paralelamente uma escola técnica denominada Berufsschule, mas não podem acessar a universidade. Trata-se do programa onde se encontra os alunos de menor renda com aproximadamente 50\% de alunos imigrantes.

Gesamtschule: uma linha mais abrangente que visa formação geral do aluno reunindo elementos do Gymnasium, Realschule e Hauptschule. Ela permite acesso 
ao ensino superior. Este programa foi desenvolvido nos anos 60 como uma forma de diminuir essa estratificação e promover a miscigenação e convivência na construção de uma sociedade condizente com as tendências da época, trata-se de um modelo educacional mais moderno voltado ao desenvolvimento pessoal e à cidadania.

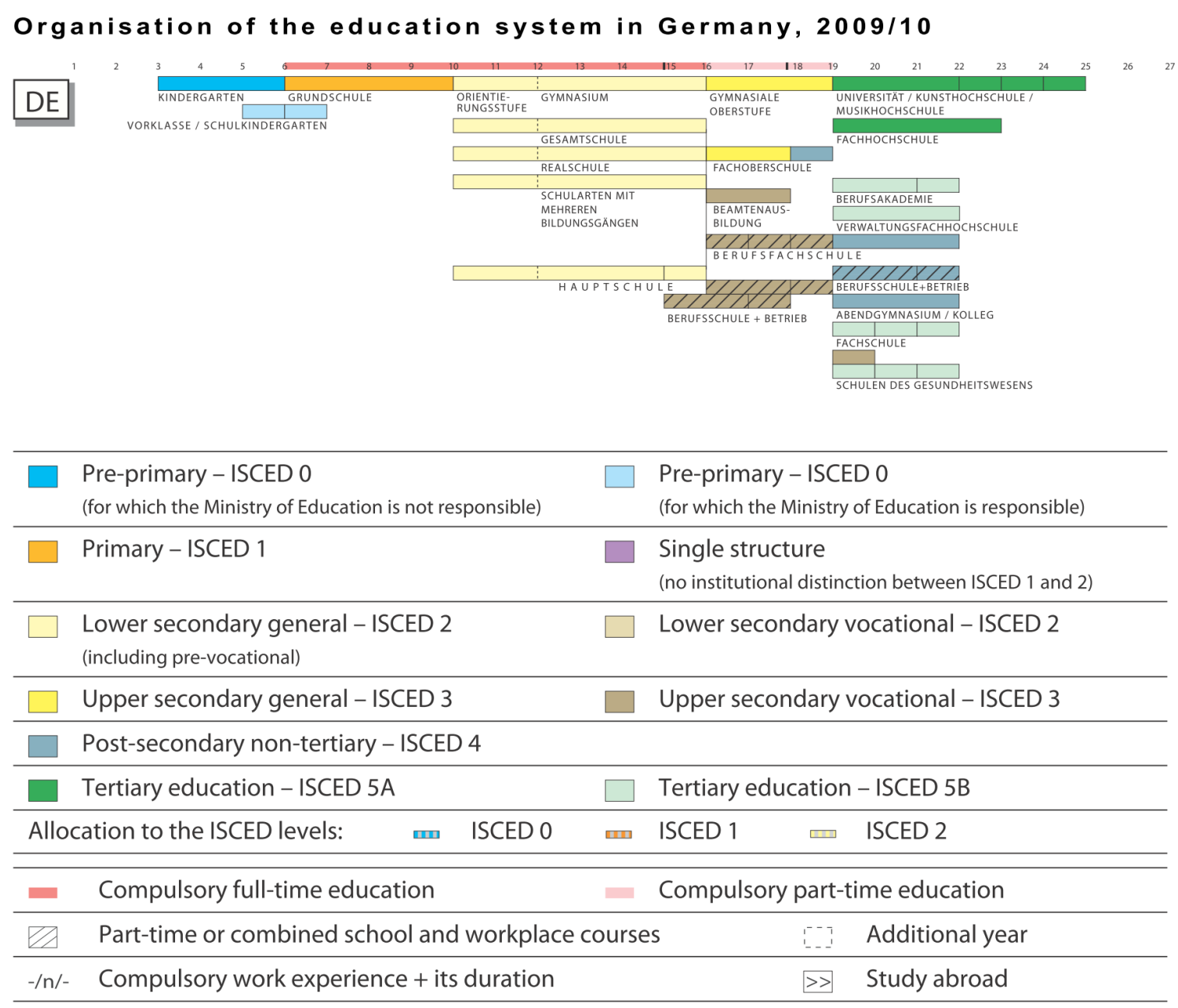

Source: Eurydice.

Quadro 29: Organização do sistema educacional alemão, 2009/10.

Schularten mit mehreren Bildungsgängen: esta classe reúne diversos programas com organização diferente das tradicionais. Normalmente os grupos são especialmente focados em determinadas áreas em momentos diferentes da formação - matemática, línguas e ciências são cursados em séries específicas; já ciências sociais, arte, música, esporte e educação religiosa são cursados por alunos de diversas séries. Os alunos são formados acessando cursos de diversos outros programas.

As escolas Gymnasium, Realschule e Hauptschule são as que efetivamente 
formam alunos alemães, pois são em maior quantidade e já fazem parte do sistema educacional a séculos representando a histórica estratificação social do país.

Quando o aluno chega ao upper secondary school, equivalente ao nosso ensino médio, o aluno se depara com dois campos para prosseguir em seus estudos: Escola de educação geral e escola vocacional.

O primeiro grande campo é o da Escola de Educação geral. Esta escola possui o programa de estudos fortemente propedêutico denominado gymnasiale Oberstufe. Com duração de 3 anos, este possui a finalidade de capacitar o aluno a fazer estudos acadêmicos e trabalhos científicos. O acesso a esse programa não é uma questão de simples escolha para os alunos, pois para que seja cursado eles devem ser aprovado com base em exames feitos nos anos anteriores e no currículo desenvolvido no primário (lower secondary school).

O gymnasiale Oberstufe é dividido em 1 ano de fase introdutória, comum aos alunos e 2 anos de qualificação, a qual permite escolhas quanto ao enfoque da aula. A qualificação é composta por matérias semestrais e os alunos possuem um núcleo básico comum ligado à língua alemã, a proficiência em língua estrangeira e estudos matemáticos. Na parte diferenciada, as opções se estendem em três grandes grupos de matérias: associadas às artes, literatura e línguas; às ciências sociais; e às matemáticas, ciências naturais e tecnologia. Caso o aluno não tenha aprendido uma língua estrangeira em estudos anteriores de forma satisfatória, é requerido que ele dobre esforços e aprenda duas estrangeiras nesse período de curso básico. Para título de informação, as turmas alemãs participantes desta pesquisa se enquadram da seguinte forma: DELe tinha qualificação voltada para a vertente científica; DEGr, era composta por alunos que optaram pelas qualificações em ciências humanas.

As escolhas ocorrem aprofundando-se em dois outros assuntos nos outros cinco períodos semanais ou por continuação aprofundada dos estudos anteriores por quatro períodos. As matérias existem em dois níveis de aprofundamento e cabe ao aluno balanceá-las respeitando algumas regras escolares com base no exame de qualificação Abitur (um vestibular unificado que garante a continuação no ensino superior e possui alguma semelhança com o ENEM aqui do Brasil).

O segundo grande campo são as escolas vocacionais e treinamento vocacional em sistemas duais. Essa modalidade tem a finalidade de habilitar os alunos a de trabalhos que necessitam de qualificação específica. A 
Berufsfachsschule e a Fachoberschule se dão em período integral e a Berufsschule ocorre em meio período adicionado a estágios remunerados. Um pouco menos que 2/3 da população jovem está em programas vocacionais.

A Berufsfachsschule tem a finalidade de desenvolver habilidades vocacionais específicas e dedica algum tempo para expandir o conhecimento geral adquirido anteriormente. O curso se dá em período integral, mas dependendo da escola, existem estágios regularizados por legislação específica. Sob certas condições, quem faz essa escola pode requerer os exames para cursar o Fachhochschule (escola de ensino superior técnica), mas isso depende do currículo do aluno. Os alunos ocupam cargos de negócio, cargos na indústria, economia doméstica e trabalhos sociais.

A Fachoberschule só pode ser cursado por aqueles que conseguiram certificação suficiente nos anos anteriores. Ele tem a finalidade de desenvolver habilidades teóricas e práticas em caráter propedêutico em direção ao Fachhochschule (ensino superior técnico). O curso tem língua alemã, língua estrangeira, matemática, ciências naturais, economia e sociedade e estudos voltados para o campo técnico específico. Os estágios são rigorosamente controlados e os alunos acabam indo em direção á administração de empresas, setores de tecnologia, trabalhos relacionados à saúde, nutrição, design, agricultura.

A Berufsschule é dedicada a quem cursa o sistema dual, no qual o aluno faz estágio remunerado em empresas. Para cursá-lo só é preciso que o aluno já tenha passado pelo período de escola integral obrigatório. Nele o aluno trabalha 3 ou 4 dias por semana como estagiário nas empresas e mais quatro períodos por semana na escola sendo que o treino vocacional, em ambiente de trabalho, é supervisionado pelas public-law corporations (aparentemente leis acordadas entre sindicatos e industrias ou comércio). O conteúdo básico é a língua alemã, estudos sociais e econômicos, religião e esportes, além de estudos específicos da área que atua. Este tipo de escola é voltado á profissionalização e pelo que parece se parecem com cursos de ensino médio com especialização técnica que temos aqui no Brasil.

Qualquer comparação entre os sistemas educacionais brasileiro e alemão deve ser feita com muito cuidado. Culturalmente a sociedade alemã parece aceitar relativamente bem a questão da estratificação social refletida nos tipos de escola que possuem. Isso porque a Gesamtschule foi desenvolvida para amenizar tal situação, mas existem em pouca quantidade por falta de requerimento da 
população, a qual parece ser muito ativa nestas questões. A relação com o setor privado também é diferenciado do contexto brasileiro, pois mesmo sob as mesmas leis da escola pública, as escolas privadas são consideradas de qualidade inferior, assim como no início da educação pública brasileira. De modo geral, cada uma das escolas públicas possui um conselho ativo de professores, alunos e pais que se responsabilizam e legislam as regras disciplinares ou regulamentos com poder limitado apenas pela Länder. Aqui no Brasil, a legislação prevê essa autonomia das comunidades sobre as escolas, mas a participação comunitária é visivelmente pequena.

\section{Bibliografia}

EURYDICE. Organisation of the education system in Germany, Education, Audiovisual \& Culture Executive Agency, Eurydice - European Commission, 2009/2010.

EURYDICE. Teachers' and School Heads' Salaries and Allowances in Europe. Eurydice - European Commission, 2009/10.

EURYDICE. National system overview on education systems in Europe and ongoing reforms. 2011 Ed. Eurydice - European Commission, Germany, nov. 2011.

FICHTNER, B.; BENITES, M.; PEREIRA, M. V. O ofício do professor na Alemanha uma entrevista, Revista Educação, n. 3(57), p. 535-546, 2005.

UNESCO, World Data on Education VII Edition, 2010/11, Brazil, versão atualizada em abril 2010. 
ANEXO2 - MODELO DE FICHA DA PESQUISA AUXILIAR 
Nome: série:

Professor: data:

Responda este encarte de perguntas em sequência com suas melhores ideias sobre o assunto e não se preocupe com notas ou algo assim. Suas respostas são destinadas para nossa pesquisa e não para avaliação.

Responda as questões em sequência, obrigado, Nupic.

Santo Agostinho, famoso teólogo que viveu no século $V$, disse certa vez: "Sei muito bem o que é o tempo até que alguém me pergunte".

Longe de buscarmos uma definição precisa sobre o conceito de tempo, e apesar de utilizarmos a palavra tempo em nosso dia a dia, pedimos que você leia atentamente as frases que seguem e marque com um $X$ a(s) que mais se aproxima $(m)$ da ideia de tempo que você tem.

a) ( ) O tempo não passa na aula do professor Chatonildo!

b) ( ) O atleta completou a prova em um tempo de 1 hora 45 minutos e 37 segundos.

c) ( ) O tempo dirá e não o há o que você possa fazer para mudar.

d) ( ) Se eu for duas vezes mais rápido, levarei a metade do tempo para chegar em casa.

e) ( ) Não temos todo o tempo do mundo, o amanhã pode nem chegar!

f) ( ) O tempo passa mais devagar nos relógios em movimento.

Escreva com suas próprias palavras: o que é tempo para você? 

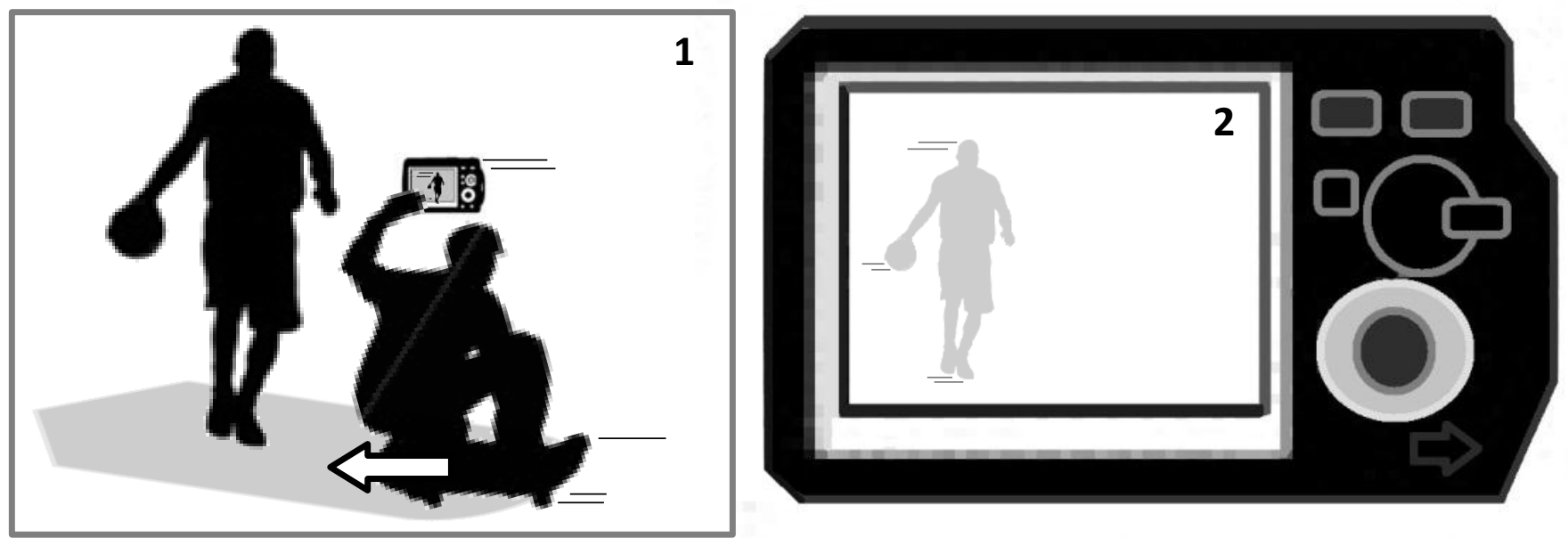

Imagine que nós, num parque, presenciemos a situação 1. O desenho ilustra um jogador de basquete parado batendo a bola no chão enquanto um skatista passa filmando a paisagem. Você consegue imaginar a trajetória que a bola faria a partir do nosso ponto de vista (1)? E do ponto de vista do skatista (2)? Desenhe as trajetórias da bola em ambas perspectivas dentro dos quadros mostrando o sentido do movimento.

Escolha uma das explicações que você considere que seja a melhor em cada caso e explique o porquê da sua escolha.

\section{Com céu aberto ao meio dia, o Sol brilha para todos!}

( ) Isso acontece para todos, pois o brilhar do Sol independe das pessoas.

( ) Isso acontece somente para quem está sob o Sol, pois quem está fechado dentro de casa não percebe seu brilho naquele momento.

O que te levou a fazer essa escolha?

\section{Um animal nasce no meio de uma selva}

( ) Isso acontece para todos, mesmo que não vejamos o filhote.

( ) Isso se tornará um acontecimento quando alguém localizar o filhote na selva

( ) Isso acontece somente para o animal e sua mãe, pois ninguém mais sabe sobre o nascimento.

O que te levou a fazer essa escolha? 
Representar onde e quando alguma coisa acontece é muito importante para179 solucionar problemas de criminalística.

- o carro sai com velocidade constante da posição $0 \mathrm{~m}$ no momento $20 \mathrm{~s}(0 ; 20)$

- o semáforo fica vermelho na posição $63 \mathrm{~m}$ no ${ }^{30}$ momento $8 \mathrm{~s}(63 ; 8)$

- o semáforo fica verde na posição $63 \mathrm{~m}$ no momento $28 \mathrm{~s}(63 ; 28)$

- O caro bate na bicicleta na posição 84 no momento $32 \mathrm{~s}(84 ; 32)$

- o semáforo fica amarelo na posição $63 m$ no momento $3 s(63 ; 3)$

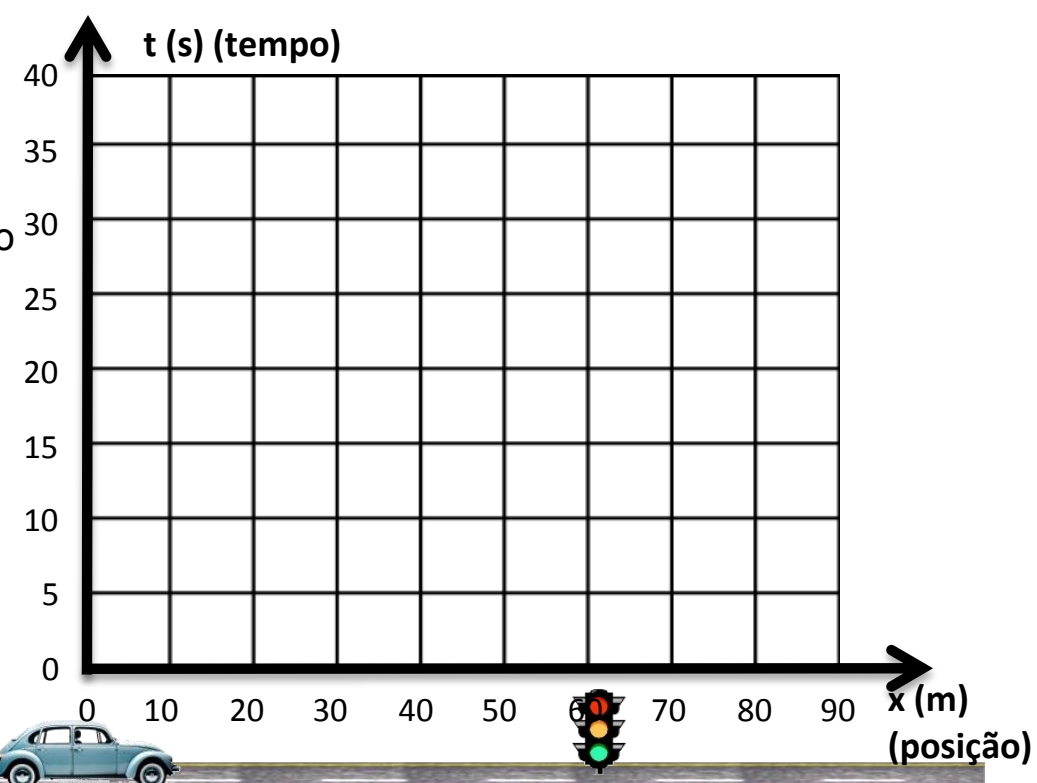

a) localize os acontecimentos ocorridos com pontos no gráfico.

b) considerando que a velocidade dos objetos sejam constantes, trace as trajetórias dos objetos ligando os pontos corretamente.

Como você indicaria que o motorista do carro ultrapassou o sinal vermelho? (escreva ou desenhe)

O que você espera aprender em um curso de relatividade? 
ANEXO 3 - SEQUÊNCIA DIDÁTICA SOBRE RELATIVIDADE RESTRITA 
Núcleo de Pesquisa em Inovações Curriculares

\section{Paradoxo dos Gêmeos 2013}

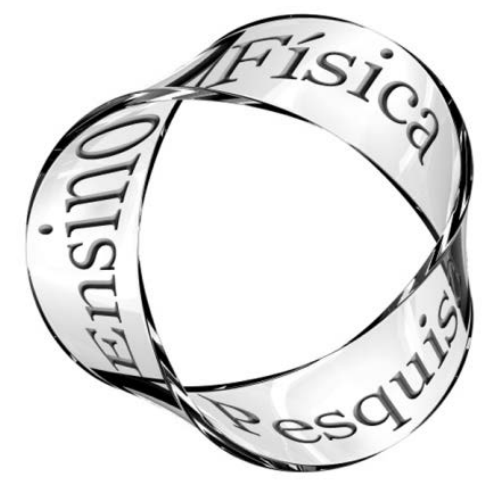

Núcleo de Pesquisa em Inovações

Curriculares

Agradecimentos

-FEOSP

FACULDADE DE EDUCAÇÃO DA USP
02 Instituto de a) Física - IFUSP

Financiado pela

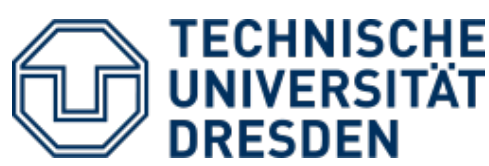

DRESDEN

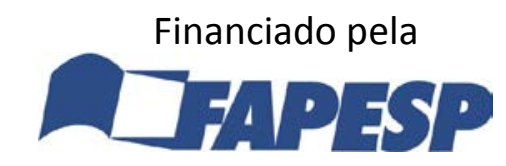




\section{PARADOXO DOS GÊMEOS INTRODUÇÃO AO CURSO}

Neste curso propomos alguns passos para professores que desejem inovar ou desenvolver práticas destinadas ao ensino de relatividade restrita a alunos de ensino médio. Desse modo, temos como grande desafio e objetivo a compreensão do não absolutismo do tempo e a existência do intervalo relativístico como um invariante por mudança de referenciais. O tema escolhido é o conhecido paradoxo dos gêmeos e a abordagem de alguns conceitos centrais da relatividade é feita de forma vinculada a pesquisas sobre inserção de física moderna no ensino médio. A construção e validação das atividades têm sido feita por professores e pesquisadores com base em dados obtidos de ambientes reais de aplicação. Um curso piloto foi aplicado em 2011 por professores regulares em classes de ensino médio de escolas públicas na cidade de São Paulo. Em 2012 professores alemães e brasileiros aplicaram o curso em suas turmas. Tais aplicações melhoraram a organização dos assuntos e instruções permitindo a construção da primeira versão completa que apresentamos aqui.

\section{VISÃO GERAL DO CURSO}

A teoria da relatividade tem origem num conjunto de experiências, deduções e interpretações que no final do século XIX e início do século XX provocaram uma revolução no cenário científico. Podemos ter uma leve impressão sobre a visão científica da época que antecede a formulação do pensamento relativístico promovido por Einstein quando lemos algumas das observações feitas por Lorentz em 1901:

"O mundo físico consiste de três coisas separadas, três tipos de materiais fundamentais: primeiro, a matéria ordinária tangível; segundo, os elétrons; terceiro o éter...

Em relação ao éter - o suporte da luz que preenche o universo inteiro -

... desde que temos aprendido a considerá-lo como transmissor não só dos fenômenos óticos, mas também dos eletromagnéticos, o problema da sua natureza tornou-se mais premente do que nunca..."

" - Lorentz (1902).

A comunidade científica pré-relativística estava especialmente preocupada com a natureza do éter e o fenômeno de propagação da luz, pois a manipulação da teoria eletromagnética de Maxwell proporcionava um valor constante para a velocidade da luz no vácuo, o que confirmava teoricamente, aos olhos da época, a existência do éter. Diversos experimentos precisos como o de Michelson e Morley em 1887 foram desenvolvidos para detectar e caracterizá-lo, mas todos utilizavam, naturalmente, as teorias do paradigma clássico para descrever os estranhos resultados que obtinham: curiosamente a velocidade da luz parecia não se alterar com o movimento do observador relativo ao éter. Com a finalidade de explicar tais resultados, 
FitzGerald, Lorentz e Poincaré desenvolveram na época uma explicação matematicamente aceitável e compatível com as equações de Maxwell - as transformações de Lorentz ${ }^{1}$.

Nesse contexto científico, Einstein apresentou sua teoria da Relatividade Restrita: uma estrutura que matematicamente convergia para as transformações apresentadas por Lorentz, mas que proporia uma revolução nos conceitos mais profundos do paradigma newtoniano. A teoria da Relatividade Geral veio posteriormente expandindo a cinemática relativística, limitada a explicações sem acelerações, para a dinâmica relativística. Com base na nova teoria que contemplava referenciais não inerciais descritos em espaço curvo, os cientistas compreenderam fenômenos até então obscuros como os desvios dos valores clássicos do periélio de Mercúrio e previram a existência de objetos jamais observados até então como buracos negros. Após extensa articulação do paradigma relativístico, a comunidade científica passou a compreender o universo físico de modo bem diferente do qual era compreendido no século XIX e do qual nós compreendemos naturalmente no nosso dia a dia. É esse universo estruturado por conceitos no espaço-tempo que consideramos importante que o aluno tenha conhecimento.

Mas isso não é tão simples de ser feito. Devemos ter em mente que o conhecimento aprendido sobre relatividade é uma estrutura multidimensional que conecta de diversas formas seus conceitos com relações matemáticas. Por exemplo, o conceito de luz tem estreita conexão com os conceitos de tempo e espaço por meio das transformações de Lorentz, os quais possuem conexão com o conceito de energia e momento relativísticos quando consideramos o conceito de inércia, e por aí vai. Quando estamos em um contexto de aprendizado é impossível compreender toda essa estrutura por um viés multidimensional e matematicamente estruturado. De fato existe um desafio aos professores que precisam transformar esse conhecimento numa linha temporal didatizada de modo a fazer com que os alunos transcendam a linearidade inerente ao processo de aprendizado em direção à compreensão da estrutura teórica à qual está se envolvendo, assim como sua relação com a realidade.

Este curso propõe os primeiros passos rumo à compreensão dos conceitos relativísticos. Ele procura tratar a diferenciação do tempo existente em diferentes referenciais promovendo o contato entre o mundo real e o mundo abstrato por meio de experiências de pensamento e discussões. Nossa escolha como porta de entrada ou recorte foi a relatividade do tempo e esta versão da sequência de ensino-aprendizagem é composta por 9 atividades que podem ser estendidas ou comprimidas dependendo da relação didática existente.

As três primeiras atividades procuram indicar ao aluno sobre a parte do seu mundo que será tratada durante o curso. Iniciamos nossa proposta sondando o significado de tempo físico por meio de uma discussão em torno de uma notícia fictícia sobre gêmeos com idades diferentes. A importância desta atividade introdutória vem do fato de os alunos não possuírem clara distinção entre as diferentes concepções de tempo que eles mesmos possuem. A segunda atividade procura trazer o primeiro contato sobre como a diferenciação temporal ocorre na realidade. Ela trata da ordem de grandeza na relação existente entre velocidade e diferenciação temporal mostrando o porquê não podemos perceber diferenciações temporais no cotidiano. A terceira atividade mostra de modo simplificado a diferença entre a relatividade newtoniana e a relatividade einsteiniana contrapondo alguns dos conceitos centrais que as sustentam.

\footnotetext{
${ }^{1}$ Assim como as transformações de Galileu são equações para mudança de referencial no paradigma clássico, as transformações de Lorentz são equações que permitem a mudança de referencial no paradigma relativístico uma vez que preservam de forma coerente a constância da velocidade da luz em todo referencial inercial.
} 


\begin{tabular}{|c|c|c|}
\hline $\begin{array}{l}\text { Atividades e estimativa de tempo } \\
\text { baseadas em aplicações reais. }\end{array}$ & $\begin{array}{l}\text { Atividades } \\
\text { Extraclasse }\end{array}$ & $\begin{array}{l}\text { Tempo } \\
(1 \text { aula = 50min })\end{array}$ \\
\hline $\begin{array}{l}\text { Atividade 1: O tempo em diferentes } \\
\text { concepções }\end{array}$ & & Aproximadamente 1 aula \\
\hline $\begin{array}{l}\text { Atividade 2: Diferenciação em } \\
\text { relógios }\end{array}$ & & Entre 1 aula e 1,5 aulas \\
\hline $\begin{array}{l}\text { Atividade 3: Entrevista com Einstein } \\
\text { e Newton }\end{array}$ & & Entre 1 aula e 1,5 aulas \\
\hline Atividade 4: Relógio de luz & $\nabla$ & Entre 1 aula e 1,5 aulas \\
\hline $\begin{array}{l}\text { Distribuição de tarefas: filmes e } \\
\text { seminários }\end{array}$ & & Aproximadamente 1 aula \\
\hline Atividade 5: Diferenciação temporal & & Entre 1 aula e 1,5 aulas \\
\hline Atividade 6: Referencial paradoxal & 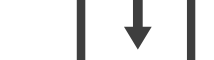 & Aproximadamente 1 aula \\
\hline Atividade 7: Eventos & & \\
\hline $\begin{array}{l}\text { Atividade 8: Caminhoneiros } \\
\text { relativísticos }\end{array}$ & & Aproximadamente 1 aula \\
\hline $\begin{array}{l}\text { Atividade 9: Viagem no espaço- } \\
\text { tempo }\end{array}$ & & Entre 1 aula e 1,5 aulas \\
\hline $\begin{array}{l}\text { Avaliação final: Apresentação de } \\
\text { seminários }\end{array}$ & & Entre 1 aula e 1,5 aulas \\
\hline Total estimado & & Entre 10 e 13 aulas \\
\hline
\end{tabular}

Observe na tabela as sugestões de solicitação e entrega das atividades extraclasse para os alunos na coluna central.

Após esse movimento de delimitação do universo de estudo, o curso parte para um movimento de abstração. A atividade 4 desenvolve um experimento de pensamento para se estudar como a constância da velocidade da luz produz a ideia de que o tempo é relativo entre dois referenciais. É importante notar que nesse ponto a noção de referencial começa a ser construída e espera-se que sua compreensão e necessidade surjam naturalmente ao longo das atividades 4, 5 e 6. A aula seguinte à atividade 4 trata-se de uma distribuição de tarefas a serem feitas pelos alunos. Cada grupo de alunos deverá executar duas tarefas: a primeira será a produção de um vídeo que será utilizado na atividade 6; a segunda será a produção de um seminário que será apresentado ao final do curso como forma de avaliação (Não deixe de olhar o texto "Distribuição de Tarefas após ATV4" presente na pasta Avaliação e Distribuição de tarefas). A atividade 5 segue em direção à matematização que estrutura o pensamento físico sobre o fenômeno e procura pontuar o significado de detalhes importantes para a compreensão desta nova forma de pensar o tempo. Grande destaque deve ser 
dado à noção de referencial próprio, pois ele naturalmente gera a errônea impressão de que existe um referencial fisicamente privilegiado, quando na verdade se trata de um referencial mais fácil de tratar matematicamente. A atividade 6 possui um caráter introdutório convidando o aluno a olhar o núcleo do paradoxo dos gêmeos com base na falsa simetria existente entre os referenciais dos gêmeos. As atividades seguintes são importantíssimas na retificação desse olhar. A atividade 7 propõe uma dinâmica para o estudo da representação de eventos.

O objetivo da atividade 8, 9 é trabalhar a representação e a interpretação gráfica dos fenômenos relativísticos em diagramas de espaço-tempo. A atividade 8 trabalha os aspectos relacionados às unidades utilizadas nos eixos do diagrama espaço-tempo. O significado de intervalo relativístico como um absoluto para qualquer referencial é estruturado utilizando-se álgebra ao final desta atividade. Finalmente a atividade 9 objetiva unir a representação geométrica às interpretações algébricas para a solução final do paradoxo dos gêmeos. A ideia é mostrar graficamente que a situação de separação e reencontro dos gêmeos após uma viajem espacial não é de fato simétrica porque o gêmeo que viaja percorre dois intervalos relativísticos em referenciais distintos enquanto o gêmeo que fica na Terra percorre apenas um intervalo relativístico justamente por nunca mudar de referencial.

Existe uma tênue e abrangente lição que permeia todo curso. Tal lição está intimamente relacionada ao que consideramos realmente absoluto no universo. Naturalmente vivemos submetidos a leis naturais que guiam nossa percepção sobre mundo como, por exemplo, a absoluta crença de que o tempo é imutável sob qualquer perspectiva. Adentrar nos estudos sobre relatividade pelo caminho proposto neste curso permite aos estudantes perceberem que o tempo tido como grande "sincronizador" de tudo o que ocorre à nossa volta é, na verdade, fruto de uma percepção limitada do homem sobre a natureza: estranhamente o tempo depende da forma com que é observado.

Mas o que fazer? Como devemos então nos situar temporalmente no universo? Quando é que as coisas efetivamente ocorrem se o período de tempo entre o nascer e o morrer podem ser diferente dependendo de como isso observado? A resposta a essa questão está na adoção de um novo e mais "poderoso" conceito absoluto constituído pela imbricada relação entre espaço e tempo matematicamente representada pelo que chamamos de intervalo relativístico. Entretanto a noção de como é o universo se modifica quando consideramos essa relação entre o espaço e o tempo. Somos levados a compreendê-lo pela união do espaço e do tempo numa forma quadridimensional onde a "duração" e o "tamanho" passam a ter relações com a velocidade relativa entre os objetos e quem os observa.

A estrutura geral do curso é composta por 3 grandes dimensões:

\section{$1^{\mathrm{a}}$ DIMENSÃO - DIAGRAMA DE FLUXO}

O fluxo é a dimensão relacionada com a conexão interna dos assuntos apresentados durante o curso. Ele é o aspecto mais positivo da sequência didática por ser responsável pela sensação de que cada atividade é parte de um todo. O fluxo do curso é representado em forma de blocos pelo diagrama de fluxo onde a sequência de ideias ou impressões é cronologicamente encadeada - veja adiante. As caixas representam a "moral da história" esperada após cada atividade; os octógonos são conectores em forma de questões que podem ser implicitamente ou explicitamente apresentadas durante o curso para que os alunos criem uma expectativa coerente com a atividade seguinte à aplicada. 
É muito importante que os professores conheçam e usem o diagrama de fluxo como um guia quando, antes ou durante a aplicação, necessitarem modificar ou adaptar o curso, pois ele carrega consigo a coerência originalmente planejada. Para os alunos, o fluxo pode ser apresentado explicitamente (exceto para situações de pesquisa).

\section{TLS - Paradoxo dos gêmeos: Diagrama de Fluxo}

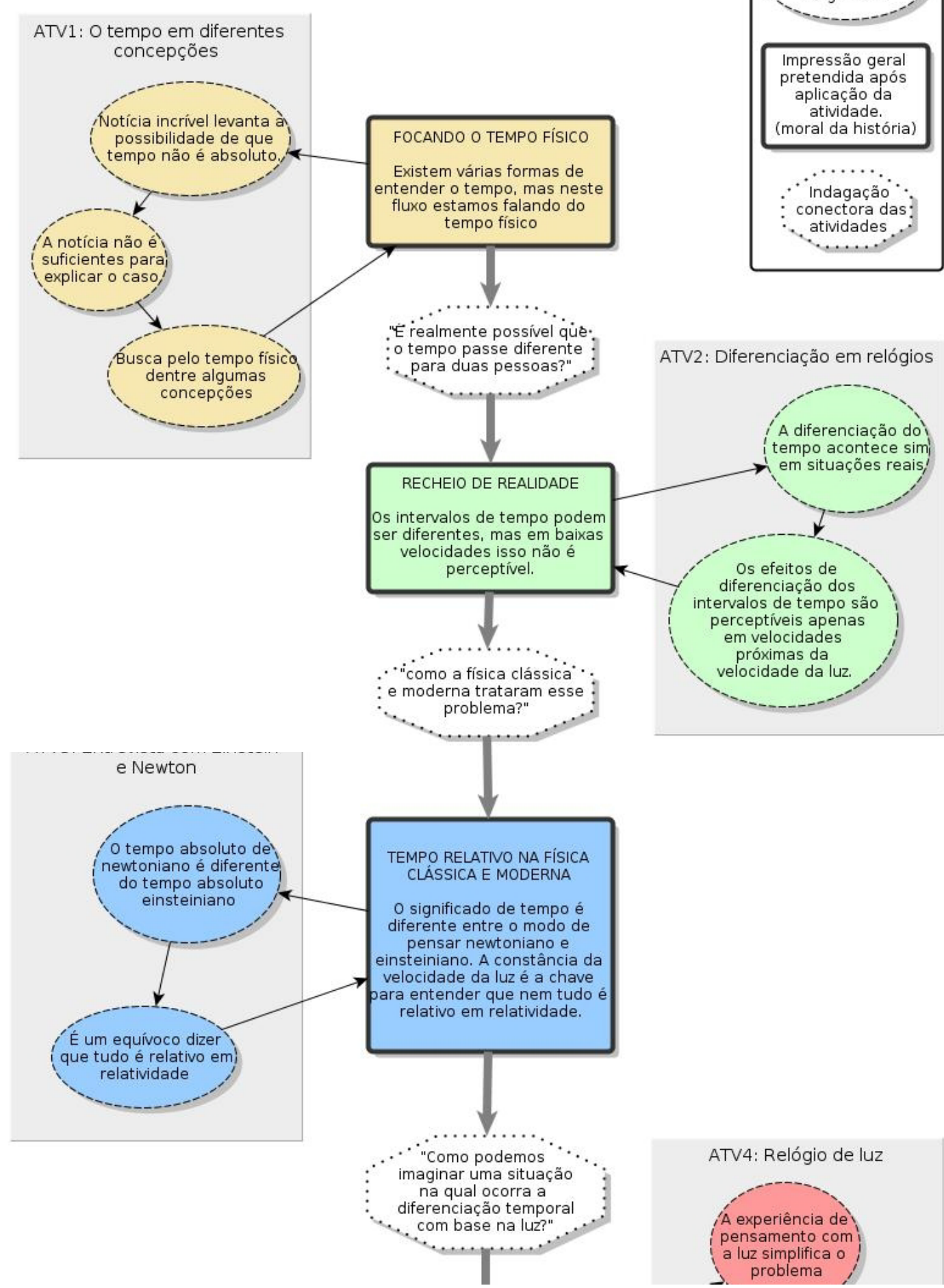



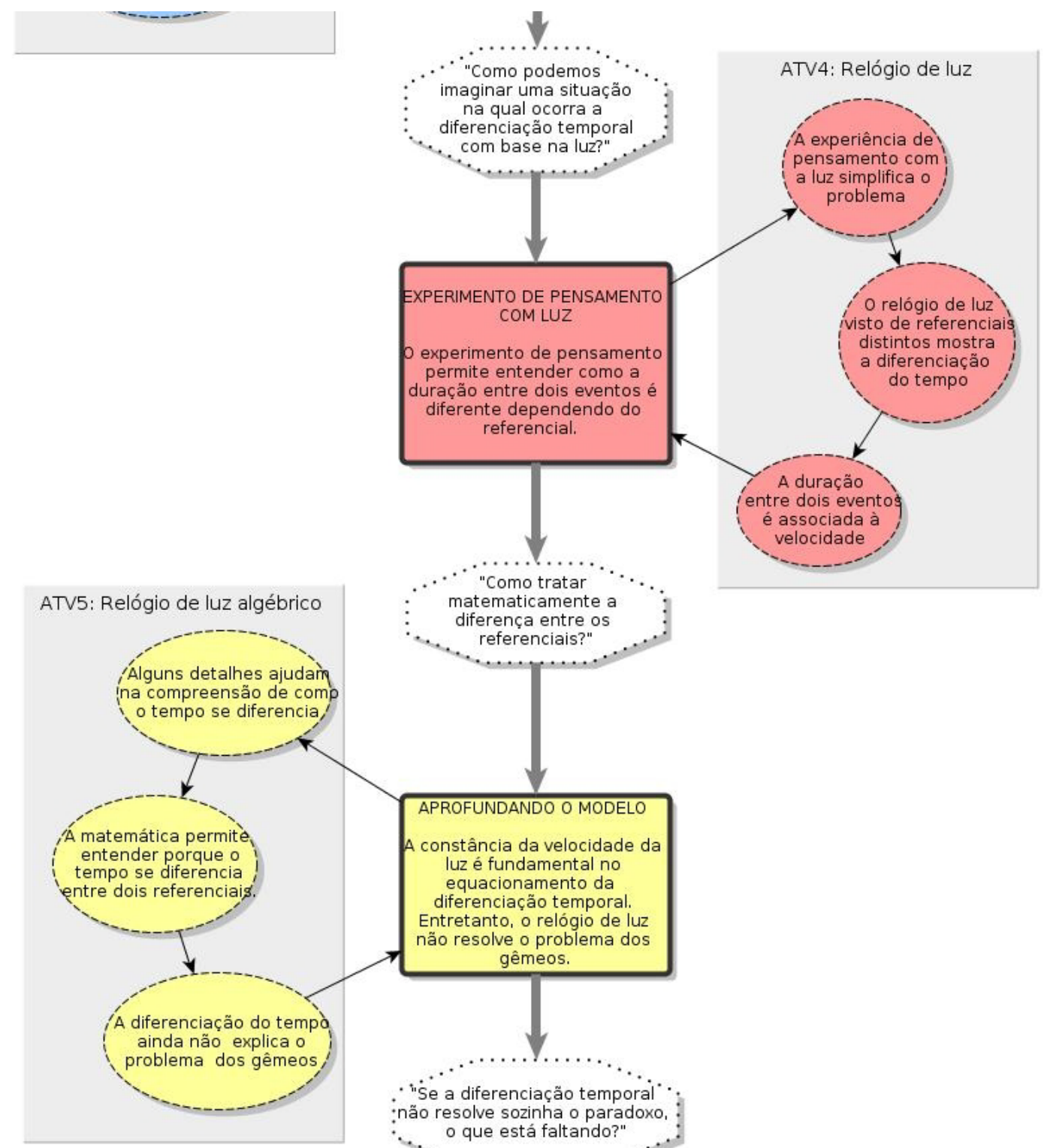

o que está faltando?"

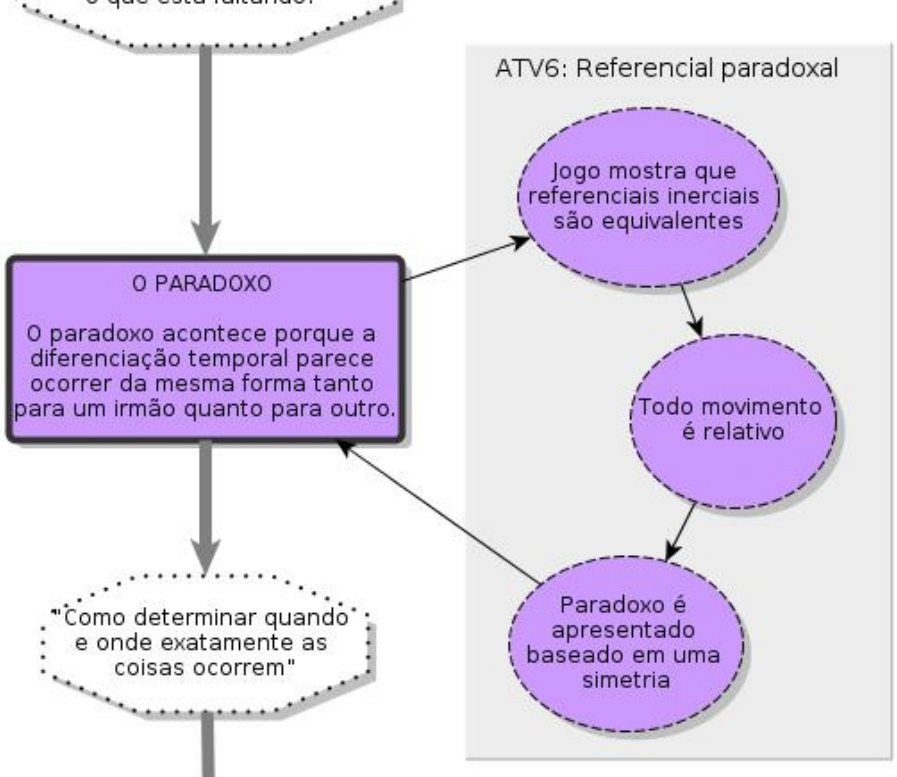




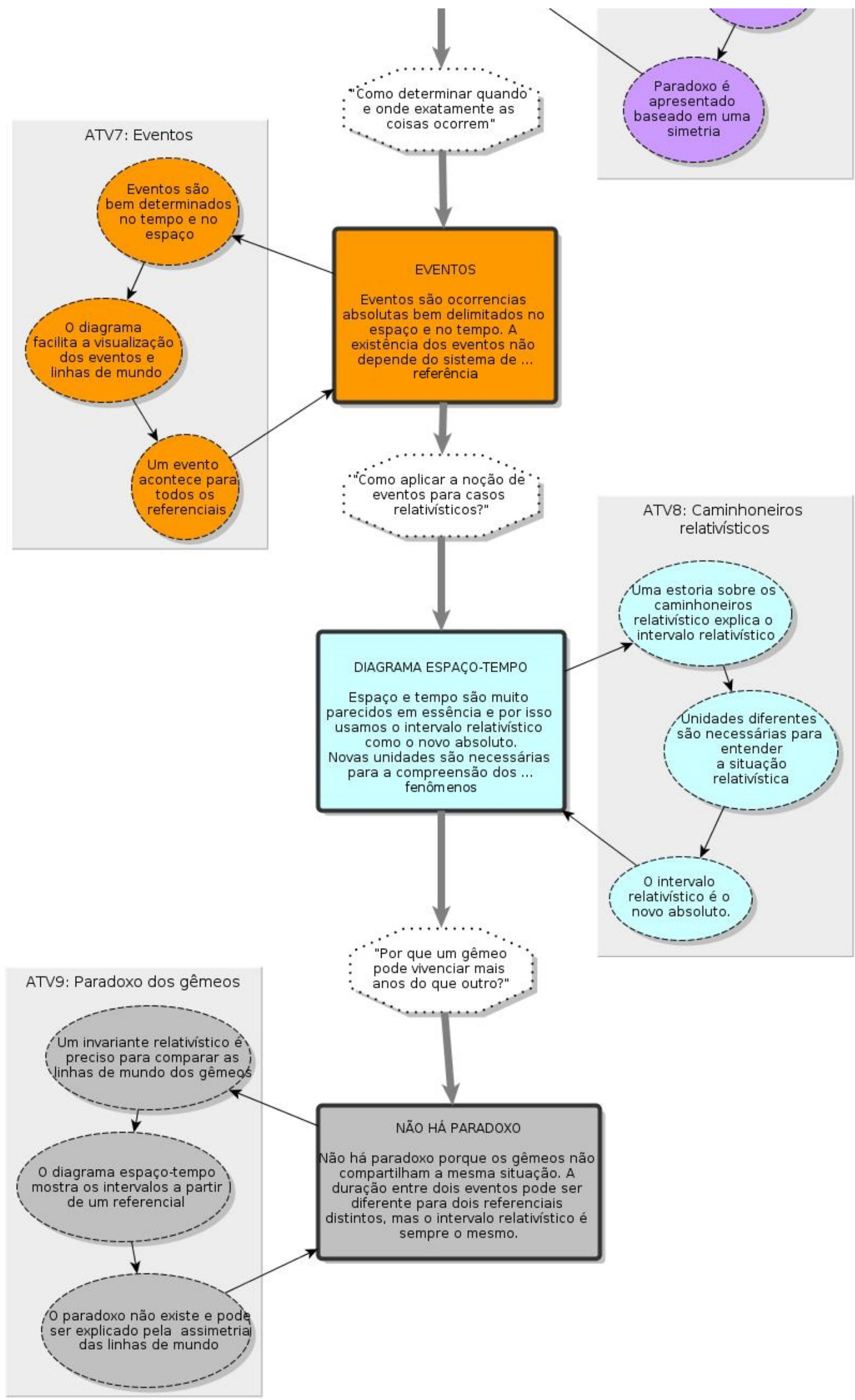




\section{$2^{\circ}$ DIMENSÃO - OBJETIVOS ESPECÍ́FICOS}

Os objetivos específicos relacionam-se com o conjunto de objetivos e práticas de ensino de cada atividade. Este conjunto está mais próximo do trabalho que o professor faz durante o preparo da aula e sua aplicação. Neste ponto é necessário que haja uma negociação entre a autonomia que o professor possui para a modificação do material e os objetivos específicos originais do material.

Nesta sequência de ensino aprendizagem, a autonomia do professor está garantida no tipo de metodologia empregada, na suplementação dos materiais utilizados e nos tempos empregados. Todos os objetivos específicos são acompanhados de sugestões sobre práticas de aplicação. Caso o professor deseje alterar o objetivo específico de algum material, entendemos que um bom equilíbrio ocorrerá se os novos objetivos forem desenvolvidos segundo o diagrama de fluxo do curso.

\section{$3^{\circ}$ DIMENSÃO - INFORMAÇÕES VINDAS DAS AULAS}

Esta dimensão está mais relacionada aos instrumentos de avaliação utilizados durante o curso, eles são quatro instrumentos:

- Avaliação local - Esta avaliação é composta por uma ficha contendo uma ou duas questões abertas a serem respondidas nos 5 minutos finais de cada atividade (não a cada aula). Sugerimos ao professor que não ajude os alunos nessa tarefa e que não a deixe como tarefa para casa. Trata-se de um pequeno desafio que exige uma pequena síntese individual articulando a "moral da história" presente no fluxo referente à atividade. Na perspectiva do professor, a função desta avaliação é acessar informações rápidas e constantes sobre a interpretação dos alunos quanto aos objetivos centrais da atividade que foi feita. O professor também pode utilizá-la como feedback de sua própria atuação com relação aos objetivos originalmente indicados.

- Avaliação intermediária - Esta avaliação tradicional é opcional. Trata-se de um pequeno conjunto que conta com questões fechadas, abertas e alternativas relativas às atividades $1-6$ (sugerimos que seja aplicada após a atividade 6). O professor pode aplicá-la em classe individualmente, respondendo-a em forma de discussão coletiva ou como trabalho para casa. É importante notar que o tempo destinado a esta avaliação não é contabilizado na tabela acima. Assim, é importante que o professor fique atento para o tempo disponível para o curso.

- Apresentação de seminário - A avaliação final deste curso se dá em forma de seminários cujos temas são relacionados a cada atividade compondo um mosaico que expande e complementa o curso. Esta avaliação pode promover interações e discussões que permitem ao professor identificar concepções alternativas às científicas e complementar explicações sobre os conceitos já apresentados. 
É importante salientar que o curso é uma produção coletiva e está em fase de experimentação. A participação de professores inovadores que aceitem o desafio de mudarem suas práticas em busca de algum tipo de superação pessoal ou na sala de aula é fundamental para que este projeto amadureça e avance mais em direção a novos alunos e em direção a outros colegas professores. 


\section{ATIVIDADE 1 - O TEMPO EM DIFERENTES CONCEPÇÕES}

\section{OBJETIVO:}

O objetivo principal da atividade é problematizar a possibilidade do tempo transcorrido entre dois eventos quaisquer ser diferente para duas pessoas. Para isso, se propõe a situação fictícia onde dois irmãos gêmeos possuem 8 anos de diferença de idade. Este caso é exposto através de um texto curto que simula uma reportagem de jornal aparentemente verídica. Através da leitura, busca-se fazer com que os alunos reflitam sobre a possibilidade real de o fenômeno ocorrer e sobre as diferentes formas de explicá-lo. A própria reportagem apresenta explicações de caráter não físico, remetendo a ideias não reais relacionadas à Biologia e à Psicologia. Estas noções são apresentadas para que se possa conceituar o tempo físico, entendido aqui como o intervalo entre dois acontecimentos que independe das impressões das próprias pessoas, isto é, desvinculado de formas subjetivas de pensar o tempo. Considera-se este ponto relevante para que os alunos percebam corretamente a natureza do problema exposto, que, para sua solução, exigirá a reformulação de conceitos da Física Clássica.

\section{CONTEÚDO FÍSICO:}

Diferentes conceitos de tempo; conceito físico de tempo.

\section{RECURSOS:}

- Material instrucional para o professor (este)

- Matéria fictícia do jornal relatando o "caso dos gêmeos de diferentes idades" para o aluno

- Avaliação local

MOMENTOS SUGERIDOS: 1 AULA APROXIMADAMENTE

\section{PROPOSTA DE LEITURA DO TEXTO}

A aula deve ser iniciada com a proposta de leitura de uma notícia que surpreendeu a todos, o caso de dois irmãos gêmeos com diferentes idades. A leitura do texto pode ser coletiva, em que o professor ou um aluno o lê em voz alta e todos o acompanham através de uma cópia individual do texto. Durante a leitura, o professor pode sugerir que os alunos tragam trechos do texto que consideram interessantes (para organizar os comentários dos alunos, os mesmos podem ser anotados na lousa para posterior debate). É importante que o professor não dê qualquer informação acerca da veracidade da notícia, pois esse é um dos fatores de discussão no conjunto de questões que se seguem. Como sugestão complementar, pode-se pedir aos alunos para anotarem as palavras que tenham dúvida para o professor discutir a posteriori na sala. 


\section{DISCUSSÃO DO TEXTO}

Com a finalização da leitura pelos alunos, o professor pode sugerir uma discussão coletiva sobre as seguintes questões que se encontram no material do aluno:

1. O que está acontecendo com os irmãos? É possível que haja diferentes idades para irmãos que nasceram no mesmo dia, quase ao mesmo tempo?

2. As explicações apontadas pelo artigo conseguem justificar a diferença de idades entre os irmãos? Quais delas e por quê?

3. Vocês conseguiriam apresentar, de forma coerente, outra explicação para esta situação? Qual?

4. Vocês consideram que esta notícia é verdadeira? Justifique.

\section{ENCAMINHAMENTO DA DISCUSSÃO}

Inicialmente os alunos poderão apresentar as mais diferentes explicações para o caso. É importante deixar que eles se expressem para que seja possível promover um debate. Em um primeiro momento é preciso avaliar possíveis explicações de cunho fantástico, como portais para outros mundos, mutação genética futurística (mudança de idade repentina), bruxaria etc. O interessante é notar que todas estas possíveis explicações não tratam exatamente de intervalos de tempo, isto é, não significam que o tempo transcorrido foi diferente para os irmãos e cabe ao professor apresentar isso aos alunos:

- Uma pessoa que "entrasse em um portal" e "saísse no futuro" teria deixado de existir durante um período. É impossível que algo simplesmente deixe de existir por um tempo para que depois volte a existir em outro. Onde essa pessoa estaria enquanto estivesse dentro do portal? E quanto à conservação de energia, como ficaria explicado o sumiço de todo o corpo e energia dessa pessoa?

- No caso de uma mutação ou mágica que faz a pessoa ficar mais velha, isto novamente não significa nenhuma interferência no tempo físico, mas seria a subtração de parte de seu envelhecimento biológico (claro que estes casos seriam igualmente estranhos, mas o importante é frisar que nenhum equivale ao caso Cooper apresentado na reportagem).

- O mesmo vale para explicações de caráter psicológico. A sensação de o tempo fluir mais rápido ou devagar é uma percepção interna e nada influencia na passagem do tempo físico, pois se cada um de nós influenciássemos a passagem do tempo conforme nossa tristeza ou felicidade, o mundo seria um grande mosaico de tempos diferentes dependendo de quão perto se está de uma pessoa alegre ou não, o que não acontece.

O professor deve deixar claro que as diferenças são realmente de idade e não se referem a experiências mentais. Neste sentido, é necessário que o aluno compreenda que o caso não se trata de dois irmãos que perceberam a passagem do tempo de modo diferente, mas mais do que isso, que viveram quantidades de tempo distintas no mesmo universo, enfatizando a ideia de que o tempo físico passou diferentemente para os irmãos.

\section{FINALIZAÇÃO E QUESTÕES DE REFLEXÃO}

O professor pode finalizar enfatizando que de acordo com a teoria da relatividade o tempo realmente não é absoluto. Vale finalizar a atividade ressaltando aos alunos que a reportagem é fictícia, embora casos semelhantes podem realmente acontecer. Como exemplo, na próxima atividade haverá uma discussão sobre um experimento real que comprova as ideias de Einstein.

Para manter a discussão viva até a aula seguinte, deixe uma questão para reflexão (que também pode ser apresentada como tarefa para casa):

Por quê a ideia o tempo não ser igual para duas ou mais pessoas causa em nós um certo mal estar?

Você consegue pensar o que tal situação poderia causar em sua vida cotidiana? 


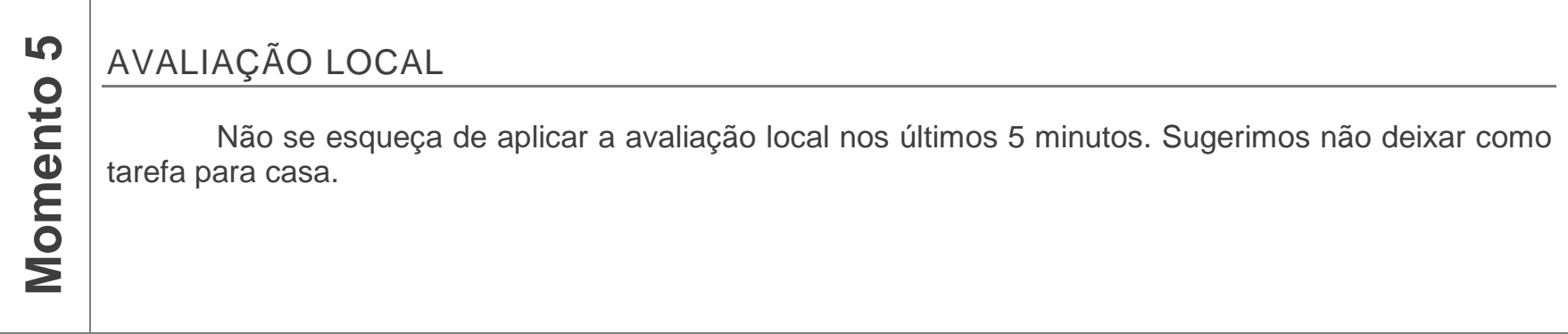




\section{Os Gêmeos}

A figura abaixo é uma cópia extraída de um artigo recentemente publicado pelo Jornal Relatos. Leiam a notícia e reflitam as seguintes questões propostas. Logo após, sigam as orientações do professor.

\section{Gêmeos são encontrados nos EUA com 8 anos de diferença entre suas idades}

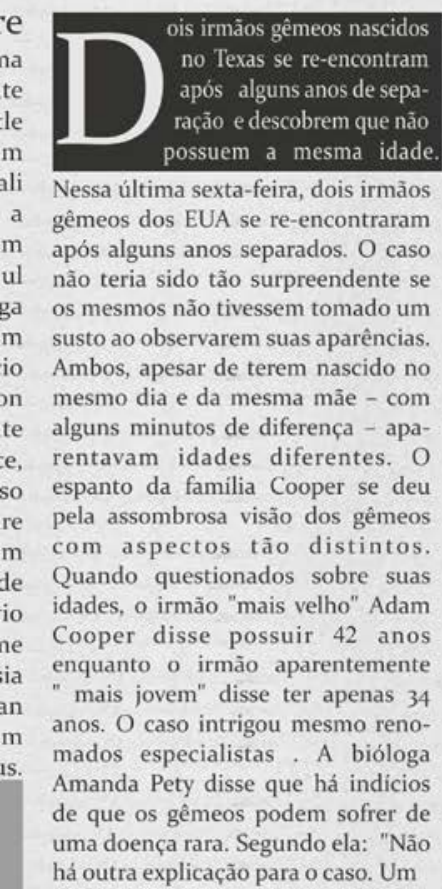

dos irmãos sofre de uma entre irmãos, comentou deformidade no gene $\mathrm{Y}$ que faz o caso. "A necessidade de com que o envelhecimento das encontrar uma identidade indivicélulas seja acelerado. Esse tipo de dual faz com que alguns irmãos transgressão genética é muito acabem por viver uma vida extrecomum em tribos indigenas doSul mamente diferente da do outro, da Venezuela. Outro pesquisador implicando em um desgaste emoda mesma Universidade de Nova cional e consequentemente, fisico. Yorque, especialista em casos Isso aparenta um desvio de contuda psiquiátricos que ocorrem

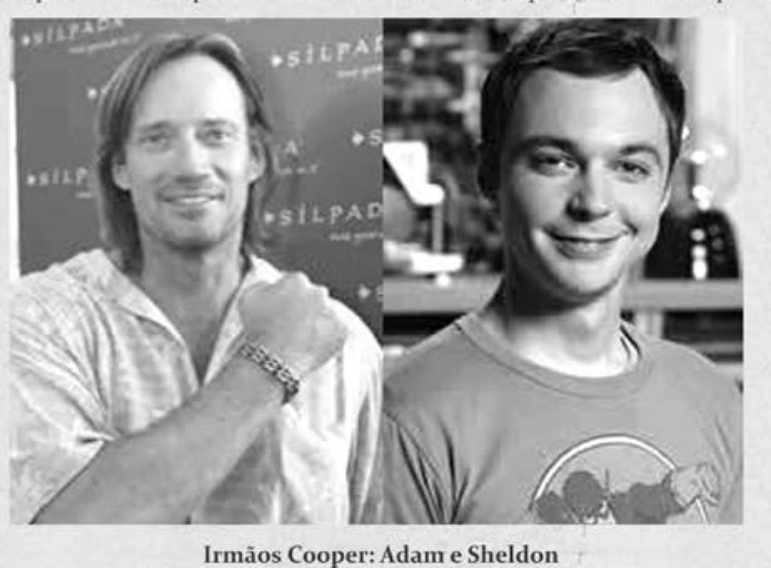

psicológico e no biológico também. Assim, apesar de aparentarem idade diferentes eles só estão fisicamente diferentes pelas experiências da vida" comentou o psicológo Gene Simmons. Caso ainda sem solução, os irmảos aproveitam o tempo livre para conversarem sobre o tempo em que ficaram separados. Adam comentou que "a diferença de idade tambén parece ter influenciado nossa experiênciais. Neste tempo fiz mais coisas, vivi mais coisas, enquanto Sheldon teve menos oportunidade de aproveitar a vida". O irmão Sheldon rebateu a afirmaçăo, dizendo: "Que absurdo! O fato é que, apesar deaparentar ser mais jovem, tenho muito mais conhecimento que Adam. Enquanto os irmãos não chegam a um acordo, a mãe dos rapazes já convocou uma vigilia entre os integrantes da igreja local para rezar pelos filhos e pedir à Deus que "salve seus filhos dessa blasfêmia".

Sheldon rejeita todas as afirmações dadas para o caso e afirma não entender o porquê de tanta confusão. Para ele, há uma explicação física muito simples para a situação!

\section{Tecnolnoia}

\section{Questões a serem refletidas pelo grupo:}

1 - O que aconteceu com os irmãos? É possível que existam diferentes idades para irmãos que nasceram no mesmo dia, 'quase' ao mesmo tempo?

2 - Das explicações apontadas pelo artigo, elas conseguem justificar a diferença de idades entre os irmãos? Quais delas e por quê?

3 - Vocês conseguiriam apresentar, de forma coerente, outra explicação para esta situação? 


\section{ATIVIDADE 2 - DIFERENCIAÇÃO EM RELÓGIOS}

\section{OBJETIVO:}

$\mathrm{Na}$ atividade anterior, que inicia o curso, foi apresentado e discutido o caso de dois irmãos gêmeos com idades diferentes. Nela, buscou-se apresentar a possibilidade do tempo físico fluir de modo diferente para duas pessoas independente da percepção e das condições biológicas de cada indivíduo. É fácil que os alunos notem que não se trata de uma notícia real e mesmo argumentem que nunca tomaram conhecimento de caso parecido. De fato, o caso da notícia não ocorre, pois necessitaria de condições muito diferentes das que vivenciamos no dia a dia, tais como velocidades relativas milhares de vezes superiores às alcançadas pelo foguete mais veloz já construído pelo homem. Contudo, quando tratamos de objetos microscópicos como partículas produzidas em aceleradores de partículas ou vindas do espaço, as quais podem viajar em velocidades da ordem de grandeza da velocidade da luz, os efeitos relativísticos se tornam mensuráveis. Assim, nesta atividade, buscamos apresentar um caso semelhante ao dos irmãos gêmeos, mas que se baseia em uma experiência real. Nesta atividade também se apresenta uma notícia, só que neste caso verídica.

O objetivo principal é discutir as condições físicas, em especial a dependência às altas velocidades, para que um fenômeno como o dos irmãos ocorra. Nesta direção, julgamos importante separar realidade de ficção, para que os alunos percebam qual é o núcleo do problema e suas causas. Isso é importante para que o conteúdo trabalhado na sequência de ensino-aprendizagem não seja tomado como fantasioso e sim como conhecimento válido.

\section{CONTEÚdO FÍsICO:}

Velocidade; condições físicas e grandezas envolvidas na diferenciação do tempo; conceituação matemática.

\section{PRÉ-REQUISITOS:}

Regra de três, porcentagem.

\section{RECURSOS:}

- Matéria do jornal Folha de São Paulo sobre medida da diferenciação do tempo

- Material instrucional para o professor (este)

- Avaliação local 
MOMENTOS SUGERIDOS: ENTRE 1 AULA E 1,5 AULAS

\begin{tabular}{|c|c|}
\hline & PROPOSTA DE LEITURA DO TEXTO \\
\hline 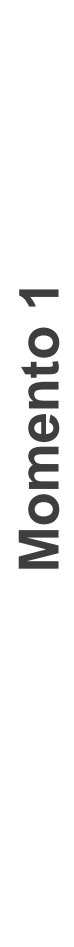 & $\begin{array}{l}\text { A aula pode ser iniciada com a proposta de leitura coletiva, em voz alta, organizada pelo } \\
\text { professor. Esta forma de leitura ajuda a controlar o tempo, mas, caso o professor ache conveniente, ela } \\
\text { pode ser feita de modo diferente. Durante a leitura, o professor pode sugerir que os alunos tragam } \\
\text { trechos do texto que consideram interessantes ou que não tenham compreendido (para organizar os } \\
\text { comentários dos alunos, os mesmos podem ser anotados na lousa para posterior debate). } \\
\text { Durante ou logo após o termino da leitura o professor pode esclarecer ou destacar alguns } \\
\text { pontos do texto. Pode-se discutir sobre os conceitos de relativo e absoluto que aparecem pela primeira } \\
\text { vez nas aulas. O importante é destacar que a ideia de tempo absoluto envolve considerar que o tempo } \\
\text { sempre flui da mesma forma, independe do referencial de medição (isto é, o tempo transcorrido entre } \\
\text { dois acontecimentos é sempre o mesmo, independente de quem observa). Já a ideia de tempo relativo } \\
\text { se refere à possibilidade de a medição do tempo em dois referenciais inerciais diferentes não ser a } \\
\text { mesma (neste caso, dois observadores podem discordar sobre o tempo transcorrido entre dois } \\
\text { acontecimentos). O professor deverá tomar cuidado para não adiantar a resposta da questão } 2 \text {, ou } \\
\text { seja, a velocidade relativa de dois observadores é o que explica a diferença de idade entre os gêmeos. } \\
\text { Também é interessante apontar a importância dos relógios atômicos. Estes últimos, por sua } \\
\text { regularidade, permitem medidas de tempo extremamente precisas. Um relógio destes pode atrasar } \\
\text { somente } 1 \text { segundo em } 65 \text { mil anos }{ }^{1} \text {. Isso mostra que a diferença de tempo medida não poderia ser } \\
\text { atribuída a um problema no relógio, mas sim à constatação de que o próprio tempo esta fluindo de } \\
\text { maneira diferente. }\end{array}$ \\
\hline
\end{tabular}

Isso equivale à um erro médio de 2 picossegundos a cada segundo que passa! Para termos uma noção da precisão destes relógios, basta sabermos que a espécie humana homo sapiens surgiu a aproximadamente 200 mil anos e se já houvesse um relógio atômico naquela época, hoje ele estaria errado no máximo em aproximadamente $4 \mathrm{~s}$. 


\section{DISCUSSÃO DO TEXTO E QUESTÕES}

Os alunos deverão ser divididos em grupos para a resolução das questões. As questões 1 e 2 podem ser discutidas de forma coletiva, abrindo espaço para que os alunos imaginem soluções criativas sobre o tema. 0 professor deverá correlacionar o contexto da atividade anterior, retratando o caso dos irmãos gêmeos. Para responder à questão 1 é importante que os alunos percebam que o caso dos dois irmãos também se refere à diferenciação do tempo para cada um deles, como ocorre no caso dos relógios. Desta forma, cria-se a relação desejada entre as notícias.

Na questão número 2, os alunos devem perceber que a diferença de tempo entre o "relógio" de um dos átomos o relógio dos pesquisadores (que estava parado junto ao laboratório) se deve ao estado de movimento relativo, ou seja, por que os átomos possuíam velocidade em relação aos pesquisadores. Assim, os alunos podem ser guiados na suposição de que um dos irmãos esteve em uma viagem que o fez envelhecer mais lentamente. No entanto, nas questões seguintes eles deverão perceber que, para que isso seja correto, as condições físicas desta viagem deveriam ser extremas. Lembramos ao professor que o objetivo da atividade é somente tratar dos motivos da diferenciação temporal, entretanto, poderá surgir o questionamento sobre como exatamente foi feito o experimento com os átomos, ou ainda, como um átomo pode possuir um relógio. Nesse caso, o professor pode sugerir que o experimento foi realizado num acelerador de partículas, onde é possível obter grandes velocidades e onde o "relógio" dos átomos é na verdade sua frequência de oscilação quando excitados por lasers com frequências específicas.

Os alunos deverão continuar a resolução das questões 3 e 4. O professor deverá corrigir as questões na lousa antes de seguir para a discussão da questão 5. Na questão 3, primeiramente, os alunos devem calcular as velocidades dos átomos, chegando aos valores de $19.200 \mathrm{~km} / \mathrm{s}$ e $9.000 \mathrm{~km} / \mathrm{s}$ para, respectivamente, os átomos à $6,4 \%$ e $3 \%$ da velocidade da luz. Deve-se tomar cuidado com a unidade, apresentada em quilômetros por segundo, diferente dos usuais quilômetros por hora ou metro por segundo.

É importante que os alunos consigam perceber as dimensões envolvidas nestas velocidades. Para isso, o professor pode dar uma série de exemplos ilustrativos. Tomando a velocidade de $19.200 \mathrm{~km} / \mathrm{s}$ temos que:

- É possível chegar à China em menos de 1s ou dar meia volta na Terra em 1s enquanto que de avião essa viagem demoraria em torno de $20 \mathrm{~h}$.

- É possível chegar à Lua em 18s enquanto que a Apollo 11 demorou 4 dias de viagem.

- É possível correr de uma trave à outra de uma quadra de futsal 500 mil vezes em 1s.

- É 56.470 vezes mais rápido que o som ou 21.300 vezes mais rápido que um jato.

- $\quad$ É 1.839.360 vezes mais rápido que o homem mais veloz, recordista dos $100 \mathrm{~m}$ rasos.

Esses exemplos ajudam a ilustrar o quão rápido são os átomos do experimento, mesmo que seja apenas $6,4 \%$ da velocidade da luz.

$\mathrm{Na}$ questão 4 deve-se calcular quanto tempo seria necessário para que houvesse diferença de 8 anos entre os relógios que acompanhou o átomo e que ficou com os pesquisadores. É importante tomar cuidado com a conversão de unidades. Uma possibilidade é converter 47 minutos para anos $\left(8,3.10^{-5}\right.$ anos), outra é converter 47 minutos para dias $(0,033$ dias).

$$
\begin{gathered}
1 \text { dia ----- } 47 \text { minutos } \\
\text { X ------8 anos } \\
1 \text { dia ----- 0,033 dias } \\
\text { X ----- } 2920 \text { dias } \\
X=88484 \text { dias }=242 \text { anos }
\end{gathered}
$$

Esse resultado mostra que somente após 242 anos os dois irmãos poderiam ter 8 anos de diferença. Devemos ainda lembrar que durante todo esse tempo um dos irmãos deveria estar constantemente viajando à $19.200 \mathrm{~km} / \mathrm{s}$. Com a interpretação desse resultado o professor pode partir para a última questão. O interessante é notar que a diferenciação do tempo somente é mensurável quando estamos em velocidades muito altas, que fogem completamente das velocidades cotidianas e, mesmo assim, muitas vezes temos pouca diferença entre os tempos. Isso explica facilmente porque ninguém percebe a diferenciação do tempo em seu dia-dia e porque um caso como o dos irmãos gêmeos não acaba se tornando uma notícia de jornal. 


\section{SISTEMATIZAÇÃO FINAL}

m

옳

É interessante que na discussão final o professor aponte que se pudéssemos viajar constantemente a velocidades próximas à da luz o caso dos dois irmãos poderia se tornar uma notícia real. Assim, a diferenciação do tempo é considerada um fenômeno real, mesmo que não seja detectada em situações comuns.

Para encaminhar a atividade seguinte, o professor pode questionar os alunos sobre como a física clássica e a física moderna tratam o problema da diferenciação do tempo. Este questionamento é importante, pois este será o tema de nossa próxima atividade.

\begin{tabular}{|c|c|}
\hline$\nabla$ & AVALIAÇÃO LOCAL \\
\hline 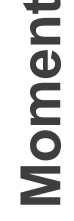 & $\begin{array}{l}\text { Não se esqueça de aplicar a avaliação local nos últimos } 5 \text { minutos. Sugerimos não deixar como } \\
\text { tarefa para casa. }\end{array}$ \\
\hline
\end{tabular}




\section{Cientistas usam relógios atômicos para mostrar diferenciação ${ }^{i}$ do tempo.}

\section{- Reportagem disponível no site:}

\section{http://www1.folha.uol.com.br/folha/ciencia/ult3o6u344720.shtml}

Uma equipe de cientistas desenvolveu um novo método baseado em relógios atômicos ópticos para mostrar, com uma precisão sem precedentes, o fenômeno da diferenciação do tempo, um dos aspectos mais fascinantes da teoria da relatividade especial.

Os resultados do relatório, publicados neste domingo na revista científica britânica "Nature", confirmam a validade da teoria da relatividade especial de Albert Einstein e apresentam um importante ponto de referência para futuras aplicações práticas, como o Sistema de Posicionamento Global (GPS, em inglês).

A diferenciação do tempo é um fenômeno pelo qual os tiquetaques de um relógio que está em movimento serão mais lentos do que os de outro relógio idêntico que estiver em repouso.

\section{(..)}

A equipe de cientistas dirigida por Sascha Reinhardt, do Instituto Max Planck, na
Alemanha, utilizou átomos que alcançavam velocidades de $6,4 \%$ e $3 \%$ da velocidade da luz. As medidas foram feitas comparando as frequências de oscilação destes átomos quando estão em movimento e quando estão parados.

$\mathrm{Na}$ teoria da relatividade postulada por Einstein, as medidas de tempo e espaço são relativas e não absolutas, já que dependem do estado de movimento do observador.

Até agora, se utilizaram os satélites GPS para medir a diferenciação do tempo, mas o estudo reivindica que o atual experimento é o primeiro teste que supera a sensibilidade obtida pelo sistema de posicionamento.

Baseado no texto anterior, responda:

1 - Com base nesta notícia, é possível formular uma explicação sobre o que ocorreu no caso dos irmãos gêmeos da reportagem anterior?

2 - Se considerarmos que a frequência de oscilação dos átomos é como um relógio natural. $O$ que faz com que o tempo marcado pelos relógios seja diferente?

3 - Sabendo que a velocidade da luz é aproximadamente $300.000 \mathrm{~km} / \mathrm{s}$, qual foi a velocidade obtida pelos átomos utilizados no experimento? Você conhece algo que atinja esta velocidade?

4 - Após 1 dia de experiência, encontrou-se uma diferença de tempo de $47 \mathrm{~min}$ entre o relógio do átomo mais veloz e relógio do átomo em repouso. Quanto tempo seria necessário para ocorrer uma diferença de 8 anos entre aqueles átomos, assim como ocorreu com os irmãos Cooper?

5 - Por que, então, não encontramos gêmeos de diferentes idades?

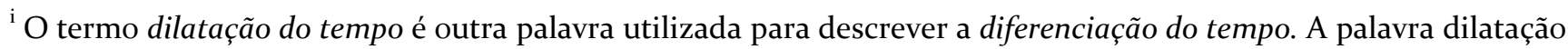
é utilizada na reportagem original e em muitos textos de divulgação científica.
} 


\section{ATIVIDADE 3 - ENTREVISTA COM EINSTEIN E NEWTON}

\section{OBJETIVO:}

Nas atividades anteriores foi debatido o conceito de diferenciação temporal e estudado as condições físicas para que este fenômeno ocorra. Neste momento, buscaremos, primeiramente, apresentar um olhar mais amplo deste problema, mostrando que a nova concepção de tempo apresentada neste curso não é apenas um rompimento com o senso comum, mas sobretudo uma ruptura com a própria forma com que a Física Clássica buscou conceituar esta ideia. Isso nos permitirá fazer uma síntese final em que devem ficar claras estas três formas de pensar o tempo: o Tempo Subjetivo ou do Senso Comum, o Tempo Absoluto de Newton e o Tempo Relativo de Einstein. Ainda nesta atividade buscamos indicar quais são os princípios que estão na base da formulação da Teoria da Relatividade. Em especial, buscaremos indicar que a constância da velocidade da luz é o mais importante fundamento para que seja possível compreender como o tempo diferencia. Este último aspecto será também trabalhado nas duas próximas atividades, que fecham um primeiro bloco sobre o Paradoxo dos Gêmeos.

\section{CONTEÚdO FÍsICO:} da luz

Transição entre o conceito de tempo absoluto e tempo relativo, princípio da Constância da Velocidade

\section{RECURSOS INSTRUCIONAIS:}

Recursos Instrucionais:

- Texto com entrevista de Einstein e Newton sobre o tempo

- Roteiro da atividade 3

- Trabalho extraclasse para aluno

- Avaliação local

\section{MOMENTOS SUGERIDOS: ENTRE 1 AULA E 1,5 AULAS}

\section{PROPOSTA DE LEITURA E DISCUSSÃO DA PRIMEIRA PARTE DO TEXTO}

A aula começa com a proposta de leitura coletiva da primeira parte do texto, relembrando o caso dos gêmeos dizendo que a solução do seu caso pode ser ajudada pela consulta a especialistas sobre o tempo físico. A primeira parte do texto trata da visão de Newton sobre o tempo. A leitura pode ser organizada pelo professor, ou feita individualmente. Após a leitura, o professor deve tirar as dúvidas dos alunos, chamando atenção para os conceitos de tempo relativo e tempo absoluto para Newton, relembrando o que foi discutido na primeira aula: a diferença entre o tempo psicológico, cotidiano, percebido pelos sentidos, em relação ao tempo físico, absoluto, medido com o relógio. 


\begin{tabular}{|c|c|}
\hline $\mathbf{N}$ & PROPOSTA DE LEITURA E DISCUSSÃO DA SEGUNDA PARTE DO TEXTO \\
\hline $\begin{array}{l}\frac{\sum}{2} \\
\frac{E}{2}\end{array}$ & $\begin{array}{l}\text { Em seguida, é realizada a leitura coletiva da segunda parte do texto, que trata da } \\
\text { visão de Einstein sobre o tempo. Novamente, a leitura pode ser organizada pelo professor, } \\
\text { ou feita individualmente; e, após a leitura, o professor deve tirar as dúvidas dos alunos, } \\
\text { chamando atenção para os conceitos de tempo relativo e tempo absoluto para Einstein. É } \\
\text { importante tomar cuidado para não responder a primeira questão proposta, que trata da } \\
\text { diferença das visões de tempo para Einstein e Newton }\end{array}$ \\
\hline
\end{tabular}

\section{DISCUSSÃO DAS QUESTÕES}

Após terminada a discussão prévia do texto, os alunos devem responder individualmente às três questões propostas ou se dividirem em pequenos grupos e discutirem as respostas. Em seguida, o professor pode discutir com a sala todas as respostas encontradas por cada grupo. Na primeira questão, é importante chamar a atenção para o significado de tempo relativo em Newton e Einstein. O tempo relativo para Newton não é o mesmo que para Einstein. Quando Newton se refere ao tempo relativo, ele está falando do tempo subjetivo ou cotidiano, como foi discutido na atividade 1 . Já quando Einstein fala do tempo relativo, é o próprio tempo físico, independente dos sujeitos, que pode ser diferente para dois referenciais. Para deixar isso claro, pode-se voltar para a atividade anterior e lembrar que o tempo medido pelos relógios, que independem da percepção de cada um, foi diferente de acordo com seu estado de movimento. O professor pode indicar que os relógios nos permitem estudar o tempo objetivo, sem que nossa percepção interfira. Por isso tanto Newton quanto Einstein atribuem grande importância a eles durante a "entrevista".

$\mathrm{Na}$ segunda questão deve-se perceber que a concepção newtoniana de tempo absoluto não aceita que dois irmãos gêmeos possam ter idades diferentes. Aqui, pode-se destacar porque os conceitos obtidos pela Teoria da Relatividade foram tão inovadores e permitiram prever fenômenos como a diferenciação temporal, que não poderiam ser pensados através da Física Clássica.

Finalmente, na terceira questão, é importante perceber que a Teoria da Relatividade não afirma que tudo é relativo. Pelo contrário, seu principal fundamento considera que a velocidade da luz é constante, o que significa que seu valor é o mesmo independe da velocidade do referencial que a emite (por exemplo, uma lanterna parada e outra em movimento irão emitir luzes que se propagarão exatamente com a mesma velocidade). Nesta etapa da aula, além de destacar a importância da luz na Teoria da Relatividade, podese indicar aos alunos que, nas próximas aulas, ela será a chave para a descrição sobre como o tempo diferencia. 


\section{SÍNTESE FINAL}

Esta atividade, diferentemente das anteriores, prevê um momento extra-classe, no qual os estudantes deverão fazer uma síntese final das discussões realizadas até o momento. Esta síntese tem o significado de uma avaliação formativa, isto é, ela deve ser pensada como forma de o professor diagnosticar a compreensão dos alunos até o momento e não se pretende com ela uma avaliação para atribuição de uma nota final. Este ponto é fundamental, pois nela os alunos devem escrever um texto autoral, privilegiando sua forma atual de pensar e se expressando com suas próprias palavras. Sua realização individualizada ainda permite que os alunos estruturem sua ideias e apresentem sua visão estabelecida até o momento. Por estas motivações, pede-se que os alunos escrevam um texto sobre o que é o tempo baseado na interpretação de dois quadros. Para que o aluno se sinta à vontade com a escrita, o professor pode indicar que ele deve escrever o texto como estivesse explicando o que é tempo, de acordo com o discutido no curso, para um colega novo, que acabou de entrar na turma. O aluno deve ter claro esse duplo compromisso, que é escrever um texto pautado no que foi discutido nas aulas mas que, ao mesmo tempo, possa ser um exercício pessoal.

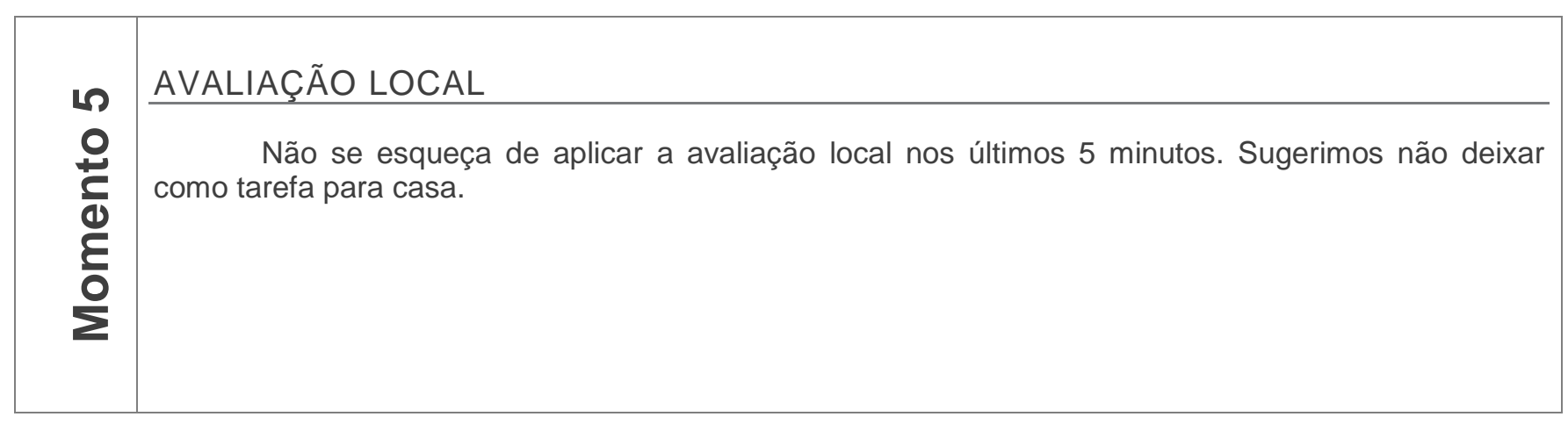




\section{Entrevista com físicos sobre o mistério dos gêmeos com diferentes idades por João da Silva}

Einstein e Newton conversam com o jornalista João da Silva sobre o tempo e como podemos entender a diferença de idade de 12 anos entre os gêmeos Adam e Sheldon

O primeiro deles, Isaac Newton, publicou em $\underline{\mathbf{1 6 8 7}}$ o livro Philosophiae Naturalis Principia Matemática, uma das obras mais importantes da História da Física.

\section{João da Silva: Caro} Newton, em sua obra, o Principia, você escreveu que o tempo é absoluto. Poderia nos explicar melhor o que é o tempo para você?

Newton: Tempo, espaço, lugar e movimento são palavras conhecidas por todos. Porém, na linguagem cotidiana costumamos relacionar estes conceitos com o que percebemos através dos sentidos. Por isso, surgem certas noções que devemos evitar se quisermos pensar cientificamente. Para tanto, precisamos distinguir $\mathrm{O}$ absoluto do relativo, o verdadeiro do aparente e o conhecimento matemático do conhecimento cotidiano.

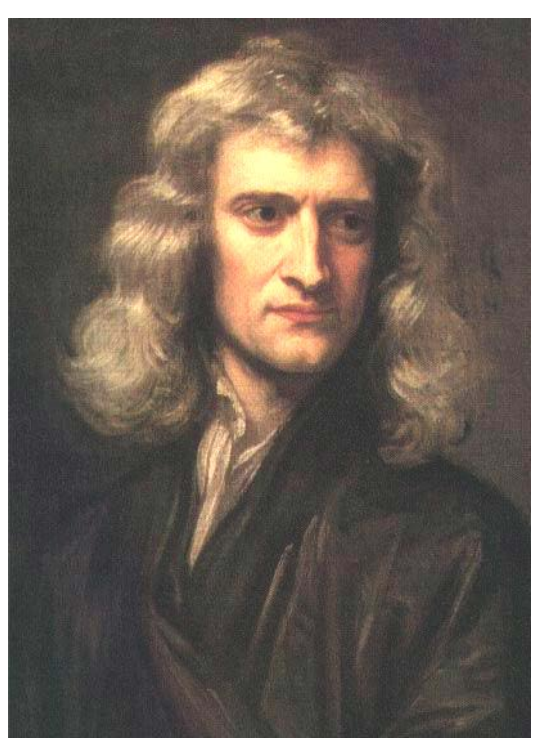

1 - Isaac Newton (\$1643 - †1727) durante a entrevista.

João da Silva: Então você diz que o tempo de verdade não é o tempo que sentimos?

Newton: Sim, isso mesmo. Para quem não gosta de física a aula parece muito demorada. Mas quando as questões fazem sentido e entendemos o problema a ser investigado, o tempo parece passar bem mais rápido. Todo o mundo já passou por uma sensação parecida, mas esta é somente uma percepção subjetiva do tempo.

Já o tempo absoluto, verdadeiro e matemático não tem relação com nada externo, flui uniformemente. Independente da forma como o percebemos, sua passagem segue sempre o mesmo ritmo. É muito comum confundirmos estas duas formas de tempo e tomarmos o tempo relativo no lugar do tempo absoluto.

João da Silva: E como podemos conhecer esse tempo absoluto?

Newton: Por meio do movimento de um objeto material, tem-se uma estimativa do tempo absoluto. Nesse caso, qualquer fenômeno físico que se repita periodicamente, independente de nossa vontade, pode ser usado como relógio: a oscilação de um pêndulo, a passagem da areia do compartimento superior para o inferior em uma ampulheta, a rotação diária da Terra, a translação anual terrestre, entre outros. Quanto mais precisa for essa regularidade e sua correspondente medição, melhor será o relógio e mais próximo do tempo absoluto estará o valor medido.

Meu amigo Huygens se preocupou muito com a construção de relógios que medissem o tempo independente de nossa percepção comum. Ele tinha muita razão em perceber que estes instrumentos são a base das melhores teorias físicas que abordam a natureza do tempo. 
A visão do tempo proposta por Newton foi dominante na comunidade científica até o começo do século XX. Até que, com a teoria da relatividade restrita publicada em $\underline{\mathbf{1 9 0 5}}$, surgiu uma nova forma de ver o tempo, alterando profundamente o que havia sido proposto por Newton.

Para entendê-la melhor, conversamos com Albert Einstein, um dos mais importantes físicos do século $\underline{\mathbf{X X}}$ :

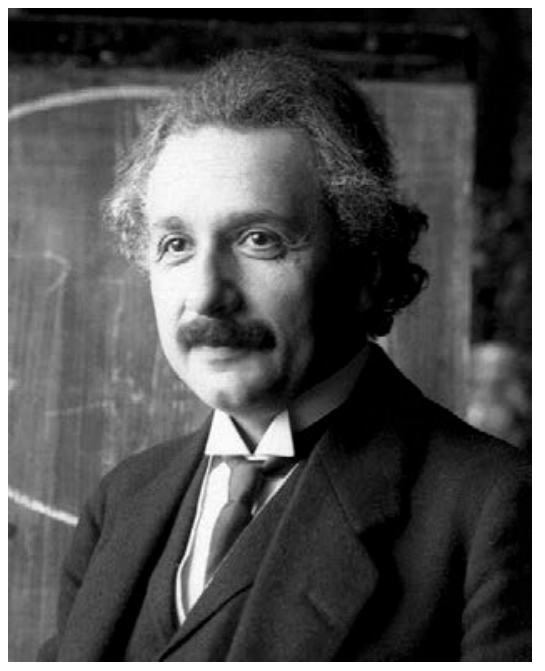

2 - Albert Einstein (1879 - \$1955) quando perguntado sobre o tempo absoluto.

João da Silva: Caro Einstein, o que você tem a dizer sobre a proposta de Newton, de que o tempo é absoluto?

Einstein: Gostaria que Newton me perdoasse, mas acho que ele está errado. A via que ele abriu era talvez a única possível, à época, para um homem dotado do mais alto raciocínio e poder criativo. Os conceitos que criou ainda hoje orientam o nosso pensamento na Física, embora saibamos que devam ser reformulados.

Eu percebi que se adotarmos o princípio de que a velocidade da luz seja sempre a mesma (c= $300.000 \mathrm{~km} / \mathrm{s}$ ), medida por qualquer observador, então a noção de tempo absoluto precisa ser abandonada.

João da Silva: E como seria então essa nova visão sobre o tempo?

Einstein: $\mathrm{Na}$ teoria da relatividade medidas de tempo são relativas, ou seja, dependem do estado de movimento de cada observador.

Quando dois observadores, que estão se movendo um em relação ao outro, comparam suas medidas de tempo entre dois eventos eles podem encontrar valores diferentes.

João da Silva: Então o tempo pode passar de forma diferente para duas pessoas?

Einstein: Sim! Um relógio pode se atrasar em relação a outro dependendo de seu movimento. No entanto, esses efeitos só são notados e medidos por um observador que não esteja se movendo junto com o objeto ou com o relógio. Um observador que se desloque juntamente com o objeto ou o relógio não vai notar nenhuma mudança neles porque compartilha do mesmo referencial, isto é, está no mesmo estado de movimento que ele. Esses efeitos dependem do observador e por isso não são absolutos, mas sim relativos a eles.

João da Silva: Isso é muito estranho! De onde você tirou essa conclusão?

Einstein: A teoria da relatividade surgiu a partir de estudos sobre a luz, sobre a eletricidade e o magnetismo. Esses estudos, que não foram feitos só por mim, mas por diversos outros cientistas, como Lorentz e Poincaré.

É importante dizer que a constância da velocidade da luz é a chave para entendermos como o tempo pode passar diferentemente para duas pessoas. Poderíamos imaginar uma situação onde um relógio de luz nos mostra a diferenciação do tempo para exemplificar esse fenômeno. Mas esse assunto eu deixo para explorar outra hora!

Responda com base na leitura das "entrevistas"

1 - A ideia de tempo relativo para Newton é a mesma para Einstein? Justifique sua resposta com base no texto.

2 - Pensando na entrevista com Newton e Einstein sobre o tempo, como você imagina que cada um deles poderia explicar o mistério dos gêmeos Adam e Sheldon?

3 - Podemos afirmar que para Einstein tudo é relativo? Discuta com base nas afirmações feitas por ele no texto. 


\section{Atividade de Síntese}

Neste momento do curso você deve ter percebido que existe mais de uma forma de compreendermos o tempo. Agora é o momento de você expressar o que tem pensado sobre tudo isso. Compare as duas figuras dos relógios abaixo. Como você interpreta as imagens com base no que temos discutido?

Redija um texto no qual você deve explicar o que é tempo com base nestas imagens. Imagine que há um aluno novo na turma e você foi encarregado de explicar a ele o que foi discutido até agora. O único material que ele recebeu foram estas duas imagens e com base nelas você deve elaborar o texto.

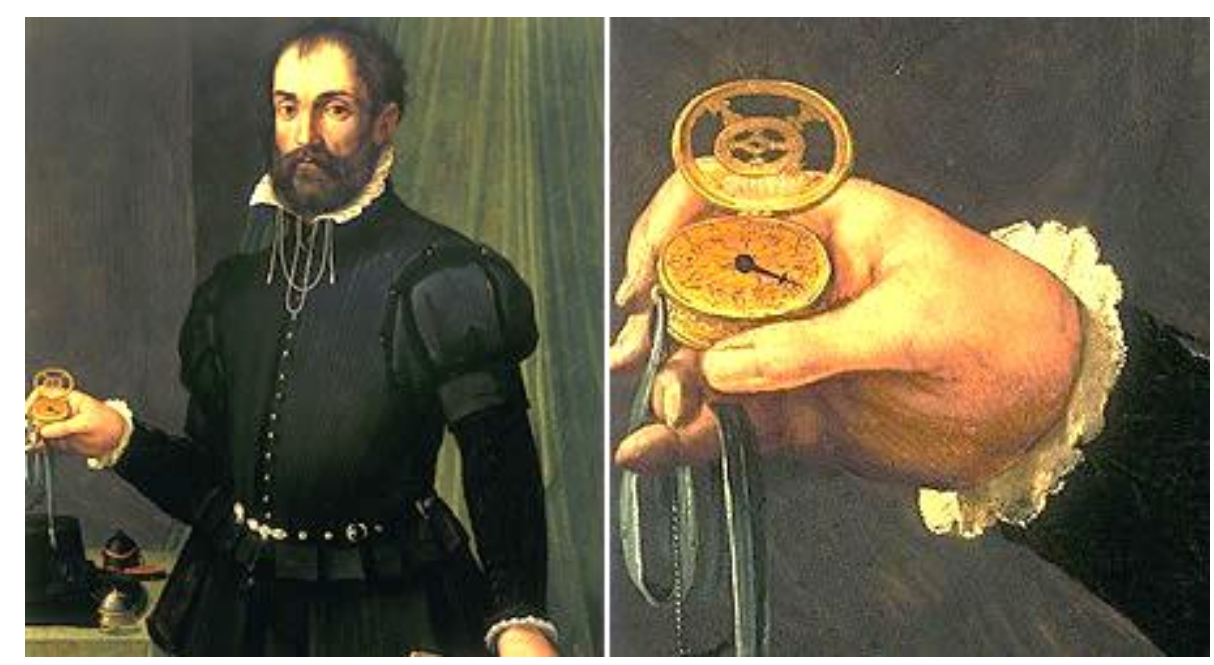

Figura 1

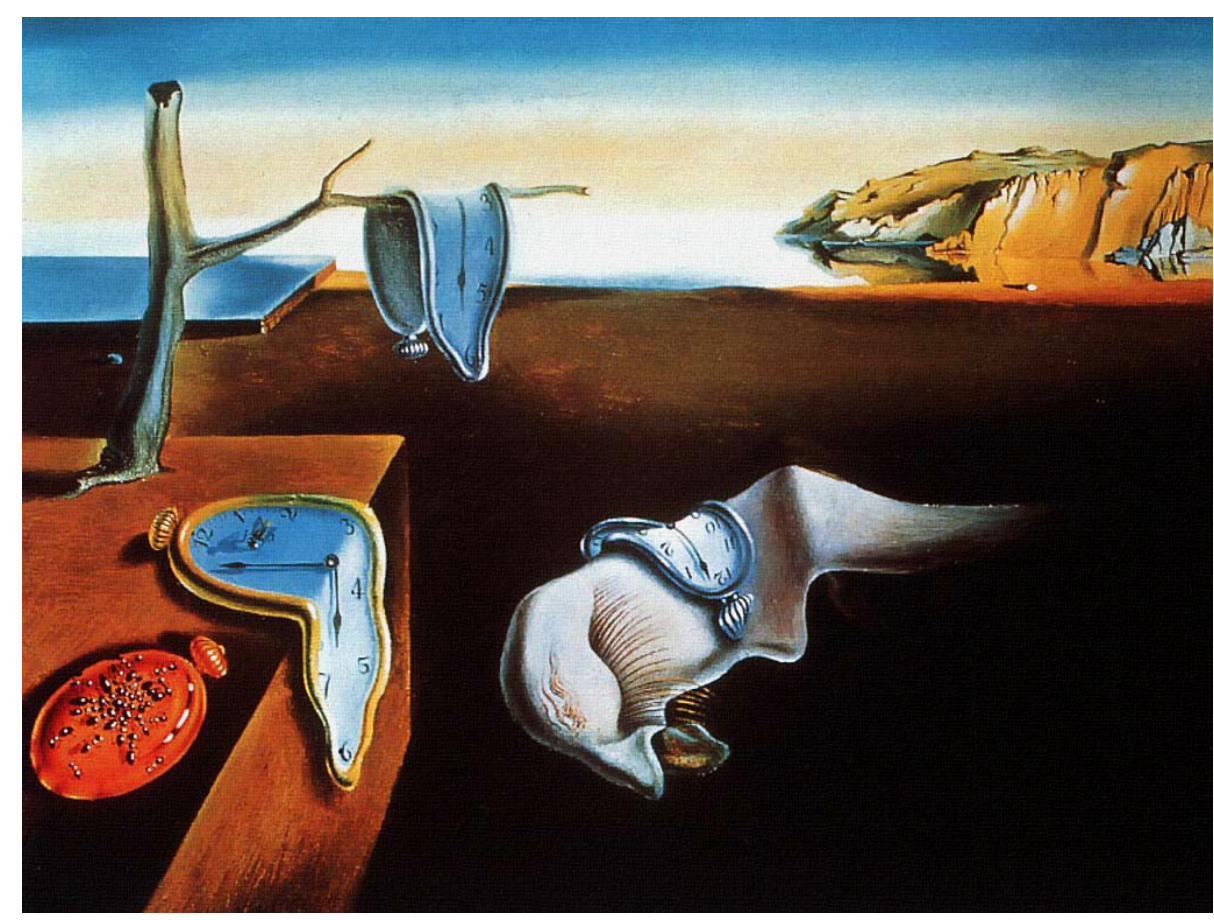

Figura 2 


\section{ATIVIDADE 4 - R-LUZ}

\section{OBJETIVO:}

Um dos motivos que tornam o conceito de referencial difícil para os alunos é o seu nível de abstração. O conceito de referencial é utilizado sempre num mundo físico inventado o qual procura refletir os elementos do mundo real. Idealizar um mundo fisicamente coerente é a chave para facilitar essa atividade. Assim, um dos objetivos desta atividade é desenvolver um experimento de pensamento que contenha os elementos necessários para a compreensão qualitativa da diferenciação temporal. Propositadamente são utilizados os conceitos de evento e de referencial os quais os alunos provavelmente não conhecem, mas poderão desenvolvê-los no nível prático.

A construção desta situação é o ponto central da atividade e deve ser realizada a partir de quatro elementos principais. O primeiro deles é a estranha característica da luz em manter-se sempre com o mesmo módulo da velocidade para qualquer referencial. O segundo está relacionado ao funcionamento do relógio de luz (R-Luz). O terceiro é a existência de dois observadores, um no skate e outro no chão. A quarta é a compreensão da pergunta relacionada à duração entre dois eventos (qual é a duração entre os eventos $A$ e $B$ vistos a partir do skate e a partir do chão?).

É importante deixar bem claro ao aluno que a constância da velocidade explorada na atividade não tem relação com a mudança de meio em que a luz se propaga, mas sim, com a mudança de referencias. Deste modo, se duas pessoas medem um mesmo pulso de luz a partir de referenciais distintos, a velocidade encontrada será a mesma "c".

Ao final da atividade, espera-se que o aluno consiga estruturar as ideias relacionadas à diferenciação temporal com base nas medições feitas pelos dois observadores presentes na situação. Devido à natureza do assunto, não recomendamos criar qualquer tipo de suspense quanto ao que será estudado; deixar claro os passos que serão tomados na atividade logo no início faz parte dos objetivos desta atividade.

\section{CONTEÚDO FÍsICO:}

Noção de duração temporal; a constância da velocidade da luz e seu significado em referenciais distintos; diferenciação temporal relativística.

\section{RECURSOS:}

- Material instrucional para o professor (este)

- Roteiro de atividade para o aluno

- Folha de respostas para o professor

- Avaliação Local

\section{MOMENTOS SUGERIDOS: ENTRE 1 AULA E 1,5 AULAS}

A construção do conceito de diferenciação temporal necessita de um grande número de outros conceitos. Tendo isso em vista, salientamos este assunto também estará presente nas atividades seguintes e sugerimos que o professor não procure esgotá-la nesta atividade.

Caso o professor sinta necessidade, a abordagem sobre o conceito de referencial pode ser feita. Sugerimos que a discussão seja ancorada na situação proposta e se limite aos exemplos no próprio experimento de pensamento apresentado. Os conceitos de "referencial", "eventos" e "intervalo" aparecem no texto da atividade, mas serão trabalhados de forma recorrente e com mais clareza em atividades futuras. 


\section{APRESENTANDO O EXPERIMENTO DE PENSAMENTOAPRESENTANDO O EXPERIMENTO DE PENSAMENTO}

Sugerimos que o professor inicie apresentando uma visão geral das atividades da aula, especialmente quanto à construção da situação imaginária e do R-Luz para que possa ser feita a comparação entre disparo e detecção no R-Luz. Nesse sentido, sugerimos debater rapidamente ou apresentar por que o experimento proposto é necessariamente de pensamento. São três os motivos principais: não é possível ver um pulso de luz que não esteja direcionado aos nossos olhos, como é sugerido nos desenhos; A velocidade da luz é muito grande para que fosse possível enxerga-la com os olhos; As velocidades envolvidas são tecnologicamente inviáveis de serem conseguidas para corpos grandes como o de uma pessoa ou uma câmera filmadora.

Os problemas 1, 2 e 3 podem ser propostos como desafio ou com a ajuda do professor. Dependendo da dinâmica do debate, o professor pode optar pela leitura e pela resolução dos primeiros três problemas de forma coletiva.

\section{DISTINQUINDO OS REFERENCIAIS DO SKATISTA E DO CHÃO}

O professor pode discutir com os alunos a ideia de que os mesmos eventos se apresentam de modo diferente para observadores diferentes. No material dos alunos isso é materializado na comparação entre a observação a partir da rua e uma filmagem feita por um skatista. Uma discussão sobre a impossibilidade de um observador pertencer a dois referenciais ao mesmo tempo baseada nas figuras é encorajada. As questões 4 e 5 são importantes nesta atividade porque evidenciam a compreensão que os alunos possuem sobre o significado prático de uma mudança de referencial. A resposta à questão 5 pode ser construída com o grande grupo após tentativa por parte dos alunos.

Sugerimos que inicie discutindo a necessidade da câmera filmadora para comparar o que os observadores vêm. A ideia é que eles efetivamente observam os mesmos eventos, mas de forma diferente. O professor pode sistematizar as questões 4 e $5 \mathrm{com}$ base nas respostas dadas, mas não encorajamos uma grande discussão porque o tema é muito fechado e promove pouca diversidade de respostas.

Como não estamos tratando a situação com rigor matemático, o texto usa a noção de observador e referencial de modo informal e provavelmente os alunos o tratarão como sinônimos. De fato, um observador real sempre está localizado e observando a situação em que ocorrem os fenômenos. O referencial, por sua vez, pode ser pensado como uma estrutura rígida, com velocidade relativa e infinitamente grande de modo a estar toda parte; no experimento de pensamento, ele nos ajuda a localizar todos os lugares sem preocupações quanto à velocidade de propagação de informações. Sugerimos ao professor que somente aborde tal assunto caso alguma questão específica surja. 


\section{PASSAGENS ALGÉBRICAS}

Sugerimos iniciar esse momento explicando a cinemática do R-luz visto pelo skatista visando as características da luz de forma bem objetiva, especialmente sua invariância por mudança de referencial. A critério do professor, as questões 6 e 7 podem ser resolvidas em grupos ou coletivamente.

Compreender a dinâmica do pulso de luz quando visto pelo referencial do skatista é algo complexo porque o R-Luz é inicialmente explicado em seu próprio referencial. Assim, o entendimento a partir do referencial do skatista exige que uma mudança de referencial seja feita. A noção de que o módulo da velocidade da luz é constante para qualquer referencial é fundamental e deve ser explicada com bastante calma para que os alunos compreendam porque o intervalo entre os eventos disparo e detecção são efetivamente diferentes para os dois referenciais.

Nesse ponto da atividade provavelmente haja dificuldade na execução das passagens matemáticas que envolvem o teorema de Pitágoras, interpretação e articulação das grandezas espaço, tempo e velocidade. É interessante ressaltar o fato de que a luz tem uma velocidade de "tráfego" determinada e invariante. Proponha aos alunos que façam os problemas 6 e 7 com base no que já foi discutido deixando-os trabalhar em grupo. Sugerimos que o professor transite e auxilie os grupos sem criar expectativa de resolver as questões por eles. Sistematize os resultados alcançados discutindo o significado relativístico que diz que dois observadores possuem percepções temporais distintas dependendo de sua velocidade.

\section{CONCLUSÕES}

Sugerimos a finalização da atividade por meio de uma discussão coletiva das questões 8 e 9 as quais provavelmente surjam nos momentos anteriores.

É perfeitamente normal que os alunos relutem ou não compreendam como tais resultados se adequariam à realidade deles próprios. Uma boa discussão poderia girar em torno da capacidade humana em perceber o mundo, uma vez que tais fenômenos são imperceptíveis corriqueiramente. Outra discussão pode correr em direção à quebra do pensamento comum sobre funcionamento do mundo. $\mathrm{O}$ desenvolvimento da relatividade mostrou que a crença de que a duração é igual para todos não é compatível com o que ocorre no mundo físico.

\begin{tabular}{|c|c|}
\hline م & AVALIAÇÃO LOCAL \\
\hline$\frac{\frac{c}{0}}{\frac{\varepsilon}{0}}$ & $\begin{array}{l}\text { Não se esqueça de aplicar a avaliação local nos últimos } 5 \text { minutos. Sugerimos não deixar como } \\
\text { tarefa para casa. }\end{array}$ \\
\hline
\end{tabular}

\section{Professor, não se esqueça!}

Sugerimos que seja feita a explicação para a produção de vídeos que serão utilizados na Atividade 6 em uma aula dedicada após esta atividade. Consulte a tabela com os tempos previstos para as atividades presentes no texto de introdução e a pasta da Atividade 6 para mais informações. 


\section{R-LUZ e os tempos diferentes folha 1}

Abaixo se encontra um aparelho imaginário que vamos chamar de R-Luz, para facilitar nosso experimento de pensamento. Com ele vamos tentar explorar a questão da passagem do tempo em referenciais distintos, ou seja, vamos observar o R-Luz de duas formas diferentes procurando saber quanto tempo demora entre os dois principais acontecimentos que ele cria:

- O primeiro acontecimento é um disparo de luz. Esse é o evento A

- O segundo acontecimento é a detecção da luz. Esse é o evento B

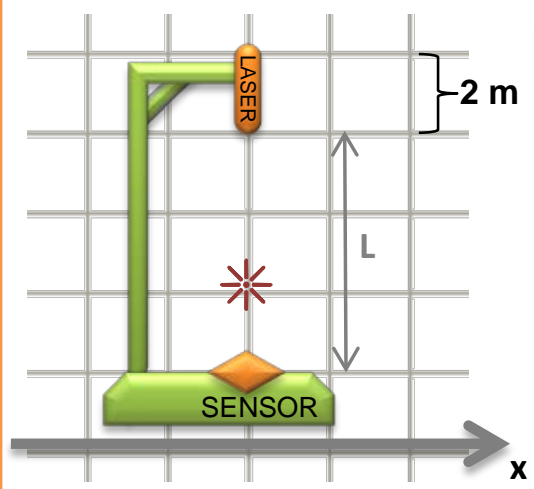

O R-Luz é um aparelho imaginário simples que dispara um pulso de luz em direção a um detector. Neste experimento de pensamento pretendemos observar o RLuz de duas formas. Na primeira, vemos e descrevemos funcionando em seu próprio referencial. Na segunda, fazemos a mesma coisa, mas observando-o a partir de outro referencial em movimento relativo ao primeiro.
1 - Você seria capaz de dizer onde cada evento acontece nesse desenho? Circule os locais onde ocorrem os eventos A e B no R-Luz.

2 - Qual a distância percorrida pelo pulso?

3 - A velocidade da luz é $c=300000000 \mathrm{~m} / \mathrm{s}$ $c=3 \cdot 10^{8} \mathrm{~m} / \mathrm{s}$

Quanto tempo o pulso demora entre sair do laser e chegar ao detector?

Agora vamos à situação! Para pensar se o tempo entre os eventos $A$ e $B$ (isto é, 0 disparo e a detecção do pulso de luz) é sempre o mesmo, vamos observar o mesmo disparo a partir de dois referenciais. Anteriormente vimos o R-Luz a partir da perspectiva de alguém parado em relação a ele. Agora a ideia é verificar se o tempo entre os dois eventos é o mesmo para quem está em movimento e o observa.

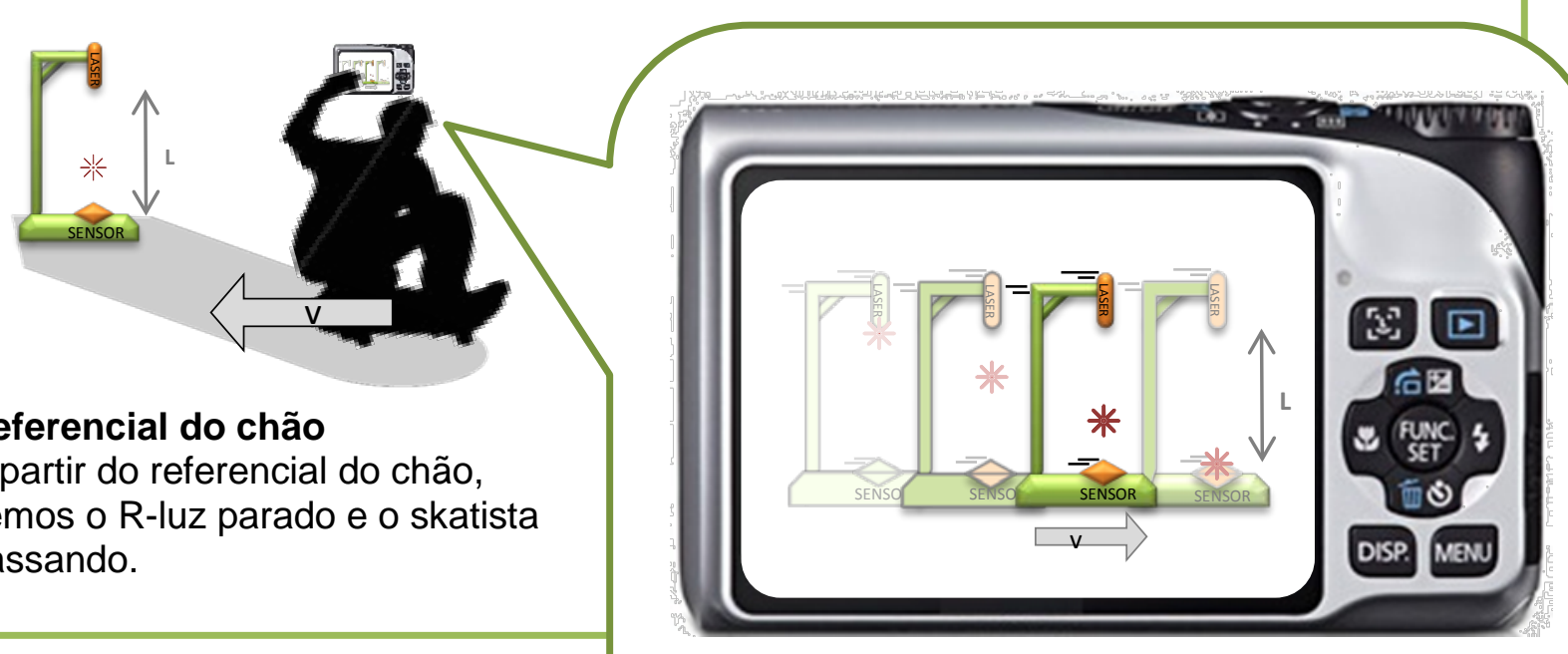

Referencial do skatista

4 - Explique por que o R-Luz se A partir do referencial do skatista, vemos o R-luz e o chão passando. desloca na filmagem do skatista se ele não possui rodas e está no referencial do chão. 


\section{R-LUZ e os tempos diferentes folha 2}

5 - Considerado o movimento do aparelho R-Luz, desenhe na figura ao lado, o caminho que o pulso de faz desde seu disparo (evento $A$ ) até sua detecção (evento B).

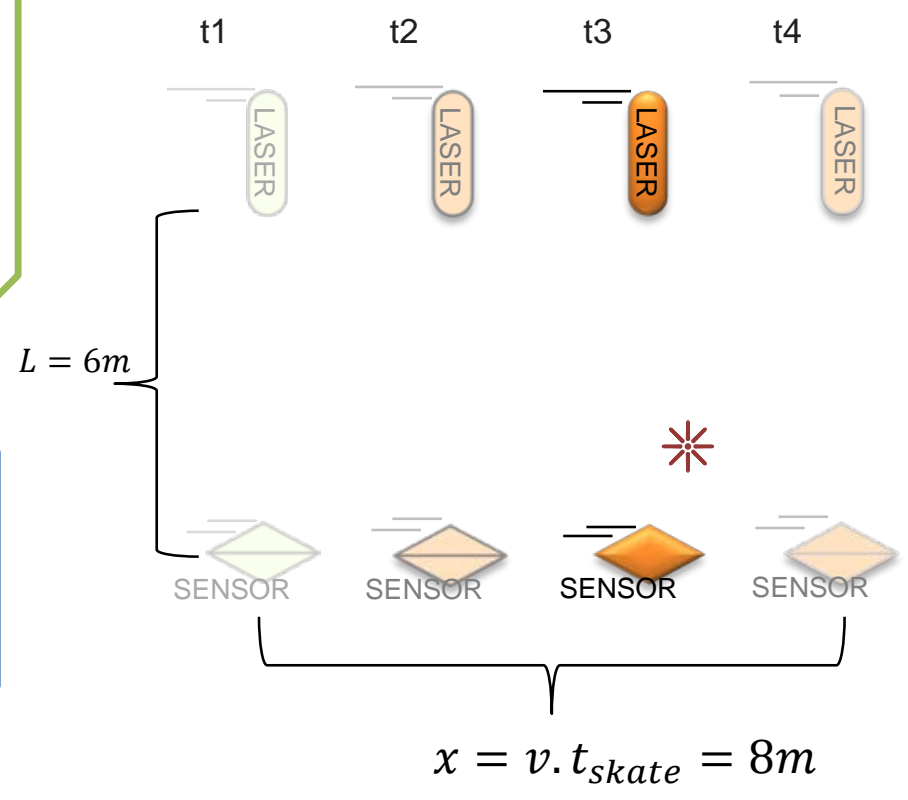

Referencial do skatista

Lembre-se que estamos tentando descobrir quanto tempo demora entre o disparo e a detecção visto pela filmagem. Por isso não podemos utilizar informações que o skatista não pudesse observar porque não podemos garantir que 0 tempo descoberto na questão 3 é o mesmo que o skatista observa.

8 - Compare o tempo obtido na questão 3 com o resultado da questão 7. Por que eles são diferentes?

9 - Qual é a velocidade do skatista? É possível alguém atingir esta velocidade? Este experimento mental poderia ser realizado em nosso dia-dia? 


\section{ATIVIDADE 4 - FOLHA DE RESPOSTAS}

1)

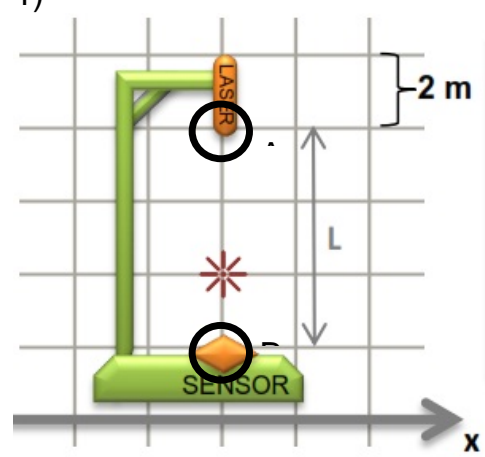

2) $L=6 \mathrm{~m}$

3) $v=\frac{\Delta S}{\Delta t}$

$\Delta t_{\text {próp. }}=\frac{\Delta S}{v}=\frac{6}{3 \cdot 10^{8}}=2 \cdot 10^{-8} s$

4)

Sugerimos ao professor que considere as respostas que evidenciem a noção/significado prático de mudança de referencial. Este tipo de questão inicia a compreensão de conceitos de mudança de referencial (não precisa de prérequisito).

Se nós nos colocássemos no referencial do skatista, veríamos o R-luz e o chão em movimento. O R-luz se desloca para a direita porque o skatista não está no referencial do chão. Ele vê todos os objetos que não estão em seu referencial em movimento.

5)
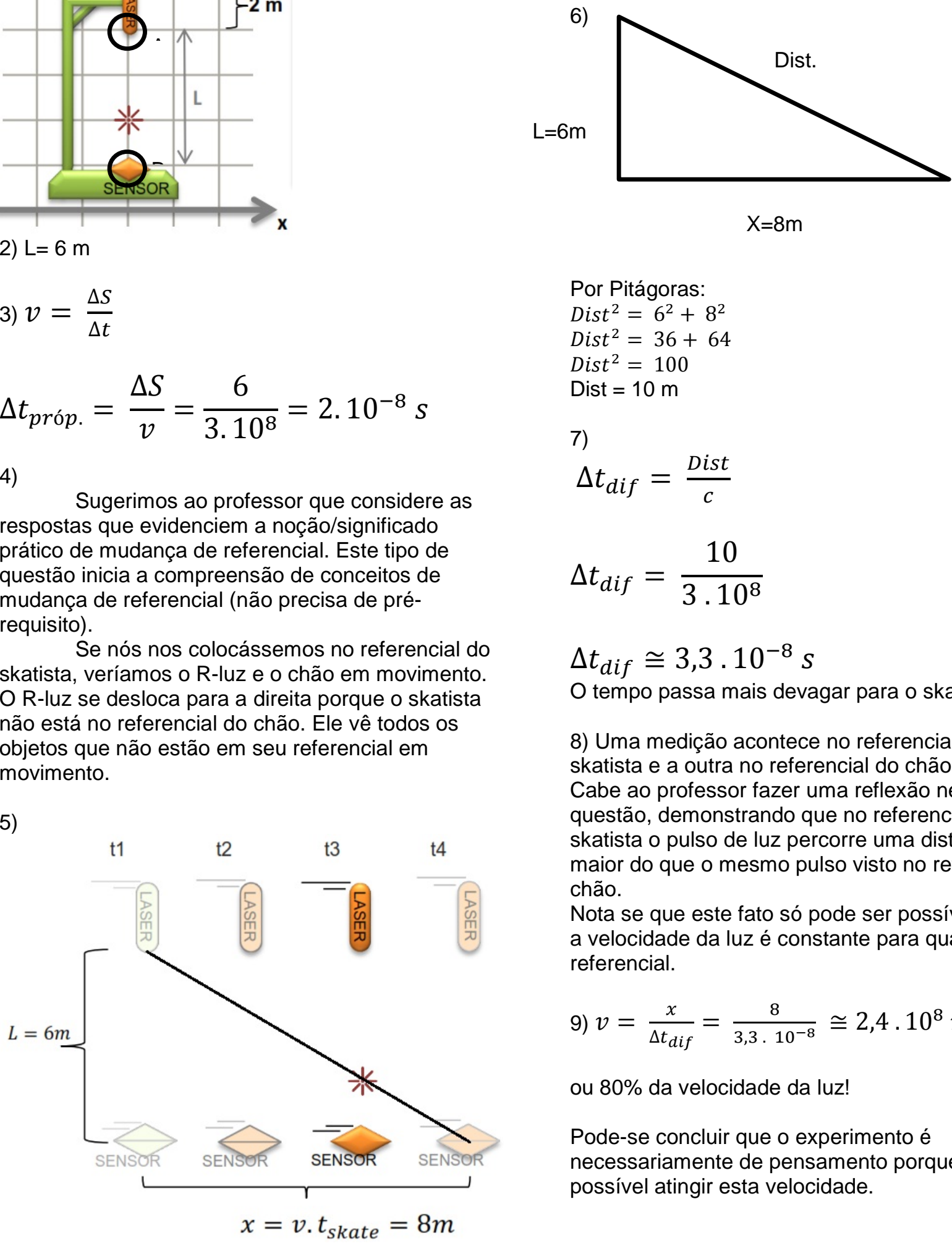

Por Pitágoras:

Dist $^{2}=6^{2}+8^{2}$

Dist $^{2}=36+64$

Dist $^{2}=100$

Dist $=10 \mathrm{~m}$

7)

$$
\begin{aligned}
\Delta t_{d i f} & =\frac{D i s t}{c} \\
\Delta t_{d i f} & =\frac{10}{3 \cdot 10^{8}}
\end{aligned}
$$

$\Delta t_{\text {dif }} \cong 3,3 \cdot 10^{-8} \mathrm{~s}$

O tempo passa mais devagar para o skatista

8) Uma medição acontece no referencial do skatista e a outra no referencial do chão.

Cabe ao professor fazer uma reflexão nesta questão, demonstrando que no referencial do skatista o pulso de luz percorre uma distância maior do que o mesmo pulso visto no referencial do chão.

Nota se que este fato só pode ser possível porque a velocidade da luz é constante para qualquer referencial.

9) $v=\frac{x}{\Delta t_{d i f}}=\frac{8}{3,3 \cdot 10^{-8}} \cong 2,4 \cdot 10^{8} \mathrm{~m} / \mathrm{s}$

ou $80 \%$ da velocidade da luz!

Pode-se concluir que o experimento é necessariamente de pensamento porque não é possível atingir esta velocidade. 


\section{DISTRIBUIÇÃO DE TAREFAS}

\section{MOMENTOS SUGERIDOS: APROXIMADAMENTE 1 AULA}

\begin{tabular}{|c|c|}
\hline & ORGANIZAÇÃO \\
\hline $\begin{array}{l}\text { ㄱ } \\
\text { 을 } \\
\frac{0}{0} \\
\frac{\varepsilon}{0} \\
\frac{0}{2}\end{array}$ & $\begin{array}{l}\text { Após a Atividade } 4 \text {, sugere-se que o professor utilize uma aula para a organização dos } \\
\text { seminários que serão apresentados pelos alunos ao final do curso e para a explicação referente à } \\
\text { produção dos vídeos utilizados na atividade } 6 \text {. } \\
\text { - Organizar a sala em grupos de } 3 \text { ou } 4 \text { integrantes para ambas as tarefas. } \\
\text { - Distribuir o material instrucional sobre a regras do QUIZ da Atividade } 6 \text {. } \\
\text { - Apresentar o vídeo "Atv6 } 1 \text { Mola desafio Como fazer" indagando os alunos sobre o que } \\
\text { está se movendo na filmagem. Posteriormente, apresentar o vídeo "Atv6 } 1 \text { Mola solucao } \\
\text { Como fazer" revelando que o primeiro movimento é feito pelo sistema massa-mola, mas o } \\
\text { segundo é uma "fraude" porque foi feito pela câmera. } \\
\text { Os grupos deverão produzir vídeos com base nas regras contidas na instrução. Para maiores } \\
\text { informações, veja a pasta "Atv6 Instrucao para produção de vídeo" presente na pasta "Avaliação e } \\
\text { Distribuição de tarefas". } \\
\text { Distribuir os temas para o seminário. Veja mais informações na pasta "Seminários" presente } \\
\text { na pasta "Avaliação e Distribuição de tarefas". }\end{array}$ \\
\hline
\end{tabular}




\section{ATIVIDADE 5 - DIFERENCIAÇÃO TEMPORAL}

\section{OBJETIVO:}

O material visa uma atividade dialogada com base em anotações relacionadas ao R-Luz em um caderno hipotético.

O objetivo é desenvolver familiaridade com os elementos presentes em problemas que envolvam relatividade. Palavras e noções utilizadas sem muita precisão em atividades anteriores passam a ter importância para a compreensão de toda a problemática em torno do conceito de tempo. A lógica matemática envolvida na diferenciação temporal também é abordada para a compreensão do papel da constância da velocidade da luz na resolução do problema. Assim, este é o momento de articular ao máximo o significado da constância da velocidade da luz para qualquer referencial utilizando a construção matemática sugerida.

Esta atividade complementa a atividade 4 e ao mesmo tempo possui características de conclusão. Assuntos relacionados às concepções temporais (atividade 1 e 3), à realidade dos fenômenos (atividade 2) e à construção de uma situação que torna a diferenciação temporal inteligível (atividade 4) são utilizados para a compreensão teórica do problema, assim surgirão provavelmente questões relacionadas a todos os assuntos anteriormente.

Assim como indicado na atividade anterior, sugerimos que o professor utilize termos como "referenciais" e "eventos", não os abordando isoladamente ou com profundidade. A ideia é procurar criar uma conexão de duas vias onde, por um lado, os elementos trabalhados em atividades anteriores forneçam significado à estruturação matemática e, por outro, o pensamento algébrico também dê significado às noções e conceitos.

\section{CONTEÚDO FÍSICO:}

Diferenciação temporal; conceituação matemática.

\section{RECURSOS:}

- Material instrucional para o professor (este)

- Material de apoio ao professor

- Folha de atividade: notas de um bom aluno

- Questões extraclasse para aluno

- Gabarito de questões extraclasse para professor

- Avaliação local 
MOMENTOS SUGERIDOS: ENTRE 1 AULA E 1,5 AULAS

\section{MOSTRANDO ERROS E ESTRATÉGIAS PARA ENTENDER A DIFERENCIAÇÃO}

Sugerimos iniciar a atividade com a distribuição e apresentação das Anotações de estudos sobre relatividade como um material hipotéticamente desenvolvido por um aluno (autor das Anotações) que estudou relatividade no curso anterior; os alunos irão reconhecer a situação como aquela proposta na atividade 4 . Como serão feitas discussões sobre alguns aspectos do texto, recomendamos a leitura de forma coletiva.

O texto de apoio com as Anotações possui algumas rasuras propositadamente feitas conceitos quando conceitos ou noções chave são apontadas pelo autor, à semelhança de equívocos comuns nas anotações que fazemos quando estamos estudando. Discuta com os alunos o porquê do autor fazer tais rasuras com a ajuda do material de apoio ao professor. Posteriormente, aborde algumas estratégias utilizadas pelo autor para o encadeamento de ideias que o levaram a compreender a diferenciação. Evite abordar assuntos matemáticos nesse momento, pois é difícil apresentar demonstrações matemáticas de forma dialogada. Sugerimos que o professor foque na compreensão e aprofundamento dos conceitos e elementos específicos.

\section{DESENVOLVIMENTO ALGÉBRICO}

Sugerimos que o professor faça as passagens algébricas da diferenciação temporal do R-Luz na lousa iniciando pela identificação dos eventos e enfatizando que serão sempre os mesmos a serem tratados em cada um dos referenciais. A ideia central nesse momento é determinar o intervalo de tempo gasto entre o disparo do pulso laser e sua detecção tanto para próprio referencial próprio do R-Luz quanto para o referencial diferente. Posteriormente, o professor pode apresentar e explicar as tragetórias do pulso para o caso 1 e para o caso 2 focando na representação matemática das distâncias de forma literal, sem números.

A partir deste ponto, recomendamos calcular a duração entre os dois eventos para o caso 1 (próprio referencial do R-Luz) e para o caso 2 (um outro referencial diferente) apontando e explorando a estranha característica que a luz possui em manter-se sempre à mesma velocidade em módulo. Como a duração entre os eventos é calculada com base na velocidade da luz, talvez o professor sinta-se a vontade para antecipar que matematicamente a diferença temporal é explicada pela constância de "c" nos denominadores presentes no cálculo do tempo. (veja o material de apoio ao professor)

O professor deve se esquivar de questões que procurem explorar os motivos físicos para o fenômeno de diferenciação lançando mão de respostas metafísicas como, por exemplo, afirmando que a natureza se "revela desta forma" ou dizendo que quando são feitos experimentos, os resultados confirmam a teoria. De fato, para avançar mais um nível na compreensão física seriam necessários outros conceitos matematicamente correlacionados os quais não são o foco destas atividades.

Finalmente apresente a união das duas equações com a finalidade de relacionar a duração no próprio referencial em função da duração apresentada num referencial diferente. É interessante explorar as dependências funcionais com a velocidade do referencial.

AVALIAÇÃO LOCAL

Não se esqueça de aplicar a avaliação local nos últimos 5 minutos. Sugerimos não deixar como tarefa para casa. 


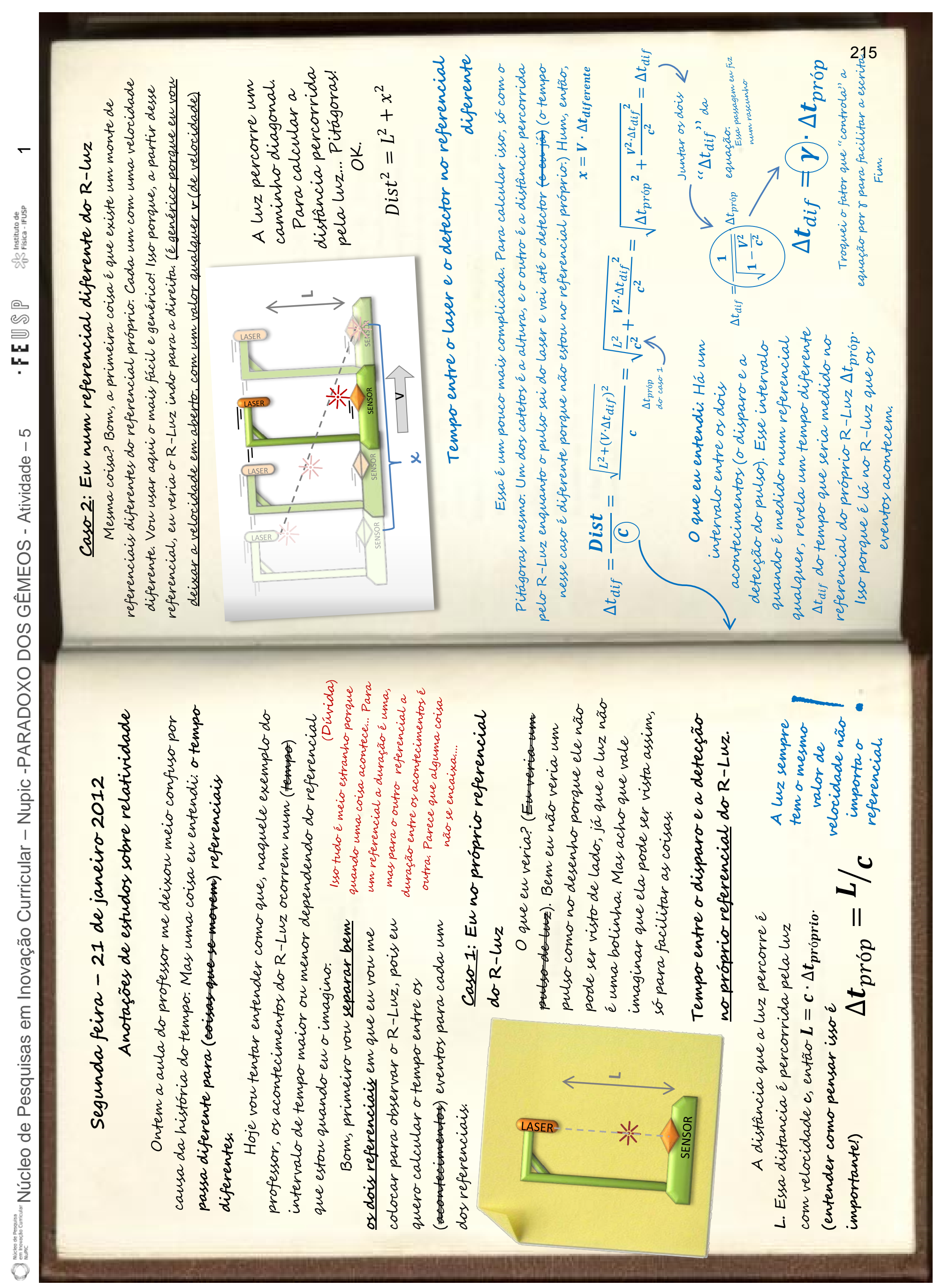




\section{Atividade 5 - Diferenciação temporal Material de apoio ao professor}

\section{Rasuras no material}

Este é um material de auxílio para discussão sobre as notas e rasuras feitas pelo aluno fictício (autor).

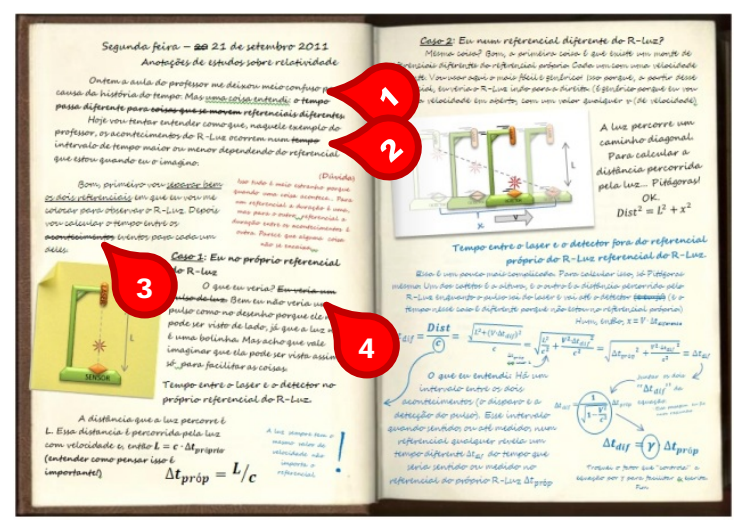

1

Ontem a aula do professor me deixou meio confuso por causa da história do tempo. Mas uma coisa eu entendi: o tempo passa diferente para (coisas que se movem) referenciais diferentes.

Um engano normalmente surge em considerar os efeitos relativísticos com os objetos, mas na verdade a diferenciação temporal ocorre entre os referenciais, ou seja, igualmente para todos os objetos que estejam no mesmo referencial.

2

Hoje vou tentar entender como que, naquele exemplo do professor, os acontecimentos do R-Luz ocorrem num (tempo) intervalo de tempo maior ou menor dependendo do referencial que estou quando eu o imagino.

Em relatividade a palavra tempo está envolta de vários significados e pode gerar confusões. De fato, as comparações são feitas entre intervalos de tempo de dois eventos. É importante observar que a diferença entre os intervalos não é provocado pelo R-Luz, uma vez que ele é sempre o mesmo para qualquer caso estudado. A diferença depende do referencial a partir do qual observamos o par de eventos.

\section{3}

Bom, primeiro vou separar bem os dois referenciais em que eu vou me colocar para observar o R-Luz, pois eu quero calcular o tempo entre os (acontecimentos) eventos para cada um dos referenciais.

De forma geral, um acontecimento é uma palavra menos precisa do que a palavra evento. Compreender a noção de evento como um acontecimento localizado no espaço e no tempo pode facilitar o entendimento.

\section{4}

O que eu veria? (Eu veria um pulso de luz). Bem eu não veria um pulso como no desenho porque ele não pode ser visto de lado, já que a luz não é uma bolinha. Mas acho que vale imaginar que ela pode ser vista assim, só para facilitar as coisas.

A luz é tratada como um objeto material comum no experimento de pensamento. Um objeto comum parado ou se dirigindo a algum lugar reflete a luz que o ilumina para várias direções, inclusive em direção aos nossos olhos, por isso o vemos. Tratar a luz como um objeto comum é uma simplificação facilita o entendimento quanto à trajetória efetuada pela luz no R-Luz, mas cria confusão quanto à essência física do pulso luminoso. A luz não pode ser "vista de lado" porque quando trafega entre o laser e o sensor ela não reflete as luzes que iluminam o ambiente como um objeto comum. Seria visível somente se os olhos do observador estivessem posicionados na trajetória do pulso e virados para o laser.

Seria interessante tratar essa dificuldade experimental em classe de modo a justificar o uso de experimentos de pensamento para facilitar o entendimento dos fenômenos. 


\section{Estratégias ou indicações do autor}

Neste ponto reforce algumas estratégias e dicas interessantes que o autor faz em suas anotações.

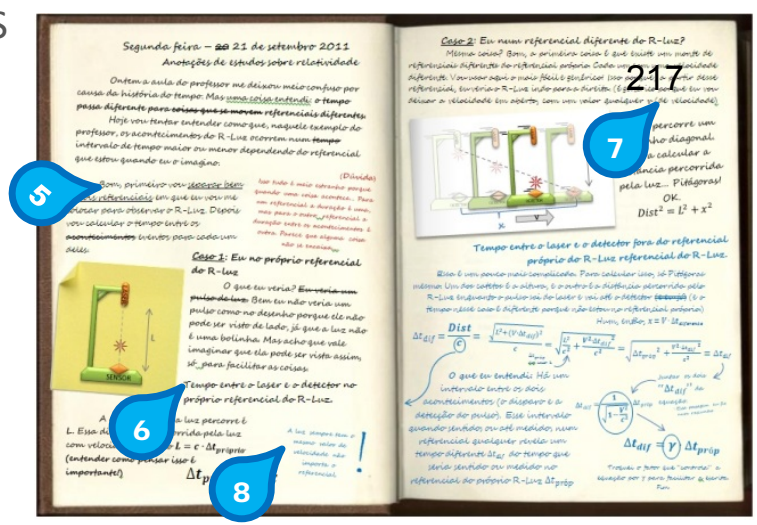

Bom, primeiro vou separar bem os dois referenciais em que eu vou me colocar para observar o R-Luz, pois eu quero calcular o tempo entre os acontecimentos eventos para cada um dos referenciais.

Organizar o problema é fundamental para a compreensão de seus resultados. Separar bem os referenciais significa nomear corretamente as grandezas. A distância percorridas pelo pulso de luz quando visto do próprio referencial é diferente da distância percorrida pelo mesmo pulso quando visto a apartir de um referencial diferente. Além disso, o autor procura deixar claro a questão que está sendo posta: calcular o tempo entre dois eventos. Procure deixar clara a questão pois muitas questões são formuladas por desconhecimento do que está sendo procurado no problema.

\section{Caso 1: Eu no próprio referencial do R-luz}

O que eu veria? Euveria um pulso de luz. Bem eu não veria um pulso como no desenho porque ele não pode ser visto de lado, já que a luz não é uma bolinha. Mas acho que vale imaginar que ela pode ser vista assim, só para facilitar as coisas.

Fisicamente não existe nenhuma diferença entre qualquer referencial, quando um evento ocorre ele ocorre em todos eles. Contudo, quando representamos nossas ideias com instrumentos matemáticos, há uma um referencial que facilita e traz informações com maior facilidade. Esse é o referencial próprio.

Quando vemos um corpo extenso como o R-Luz criando eventos parado em nossa frente, podemos dizer que estamos no referencial próprio àqueles eventos porque eles ocorrem no mesmo lugar conforme o tempo passa. Se ao contrário observarmos o R-Luz de tal forma que os eventos não se apresentem no mesmo lugar conforme o tempo passa, então estamos em um referencial diferente.

Observe que a nomenclatura utilizada nas anotações são feitas com relação ao referencial próprio do RLuz e com relação a um referencial diferente.

\section{Caso 2: Eu num referencial diferente do R-luz?}

Mesma coisa? Bom, a primeira coisa é que existe um monte de referenciais diferentes do referencial próprio. Cada um com uma velocidade diferente. Vou usar aqui o mais fácil e genérico! Isso porque, a partir desse referencial, eu veria o R-Luz indo para a direita. (é genérico porque eu vou deixar a velocidade em aberto, com um valor qualquer $v$ (de velocidade)

Ressaltar que o R-Luz pode ter qualquer velocidade abaixo da velocidade da luz quando o observamos a partir de um referencial diferente. Não conhecer a velocidade do skatista não impede que a representação matemática do problema seja feita. Deixando a equação dependendo da velocidade podemos saber a resposta da diferença na duração não só para um caso específico, mas para todas as velocidade possíveis (trata-se de generalizar o caso específico do fator de conversão y apresentado na atividade 4 para $y(v)$ dependente da velocidade.

A luz sempre tem o mesmo valor de velocidade não importa o referencial.

A constância da velocidade da luz é a chave para a compreensão da relatividade. Entender profundamente essa ideia significa toma-la como real e construir uma representação relativística do mundo, entretanto é difícil aceita-la justamente porque é totalmente contra intuitiva. Procure explicar, por exemplo, que um fóton saído de um farol de um carro em movimento se afasta do carro à mesma velocidade tanto para o motorista quanto para aquele parado na calçada. 


\section{Dedução da diferenciação temporal}

Uma estratégia interessante para determinar o intervalo de tempo em cada referencial é descobrir inicialmente a distância percorrida pelo pulso e depois descobrir o tempo utilizando-se do fato que a luz se movimenta sempre à mesma velocidade para qualquer referencial. Assim:

\section{Referencial do próprio R-Luz:}

A distância percorrida é Dist $t_{\text {próp. }}=L=c \cdot \Delta t_{\text {próprio }}$

Logo o tempo gasto é $\Delta t_{\text {próp }}=L / c$

\section{Referencial diferente:}

A distância percorrida é Dist $_{\text {dif. }}=\sqrt{L^{2}+\left(V \cdot \Delta t_{\text {dif }}\right)^{2}}$

Trate passo a passo a construção do teorema de Pitágoras e explore bem a construção do cateto $V \cdot \Delta t_{\text {dif }}$, pois se trata da distância relacionada com o movimento. Esta distância depende da velocidade relativa e seu entendimento pode ser diretamente ligado à visualização do skatista da atividade anterior.

$\Delta t_{\text {dif }}=\frac{\text { Dist }}{c}=\frac{\sqrt{L^{2}+\left(V \cdot \Delta t_{d i f}\right)^{2}}}{c}=\sqrt{\frac{L^{2}}{c^{2}}+\frac{V^{2} \cdot \Delta t_{d i f}^{2}}{c^{2}}}=\sqrt{\Delta t_{\text {próp }}^{2}+\frac{V^{2} \cdot \Delta t_{d i f}^{2}}{c^{2}}}$

Isolando $\Delta t_{\text {dif }}$, temos: $\Delta t_{\text {dif }}=\frac{\mathbf{1}}{\sqrt{1-\frac{v^{2}}{c^{2}}}} \cdot \Delta t_{\text {próp }}=\gamma \cdot \Delta t_{\text {próp }}$

É importante deixar claro que o mesmo pulso de luz possui a mesma velocidade c tanto no próprio referencial do R-Luz, quanto para o referencial diferente.

$$
\begin{aligned}
& \Delta t_{\text {dif }}=\frac{\text { Dist }}{\boldsymbol{c}}=\frac{\sqrt{L^{2}+\left(V \cdot \Delta t_{d i f}\right)^{2}}}{\boldsymbol{c}}=\sqrt{\frac{L^{2}}{\boldsymbol{c}^{2}}+\frac{\boldsymbol{V}^{2} \cdot \Delta t_{\text {dif }}{ }^{2}}{\boldsymbol{c}^{2}}}=\sqrt{\Delta t_{\text {próp }}{ }^{2}+\frac{\boldsymbol{V}^{2} \cdot \Delta t_{\text {dif }}{ }^{2}}{\boldsymbol{c}^{2}}} \\
& \Rightarrow \Delta t_{d i f}^{2}=\Delta t_{\text {próp }}{ }^{2}+\frac{V^{2} \cdot \Delta t_{d i f}^{2}}{c^{2}} \\
& \Rightarrow \Delta t_{d i f}^{2}-\frac{V^{2} \cdot \Delta t_{d i f}{ }^{2}}{c^{2}}=\Delta t_{\text {próp }}{ }^{2} \\
& \Rightarrow \Delta t_{\text {dif }}^{2}\left(1-\frac{\boldsymbol{V}^{2}}{\boldsymbol{c}^{2}}\right)=\Delta t_{\text {próp }}{ }^{2} \\
& \Rightarrow \Delta t_{d i f}^{2}=\frac{\Delta t_{p r o ́ p}{ }^{2}}{\left(1-\frac{V^{2}}{c^{2}}\right)} \\
& \Rightarrow \Delta t_{d i f}=\sqrt{\frac{\Delta t_{\text {próp }}^{2}}{\left(1-\frac{V^{2}}{c^{2}}\right)}}=\frac{\Delta t_{\text {próp }}}{\sqrt{\left(1-\frac{V^{2}}{c^{2}}\right)}} \\
& \Rightarrow \Delta t_{\text {dif }}=\boldsymbol{\gamma} \cdot \Delta t_{\text {próp }}
\end{aligned}
$$




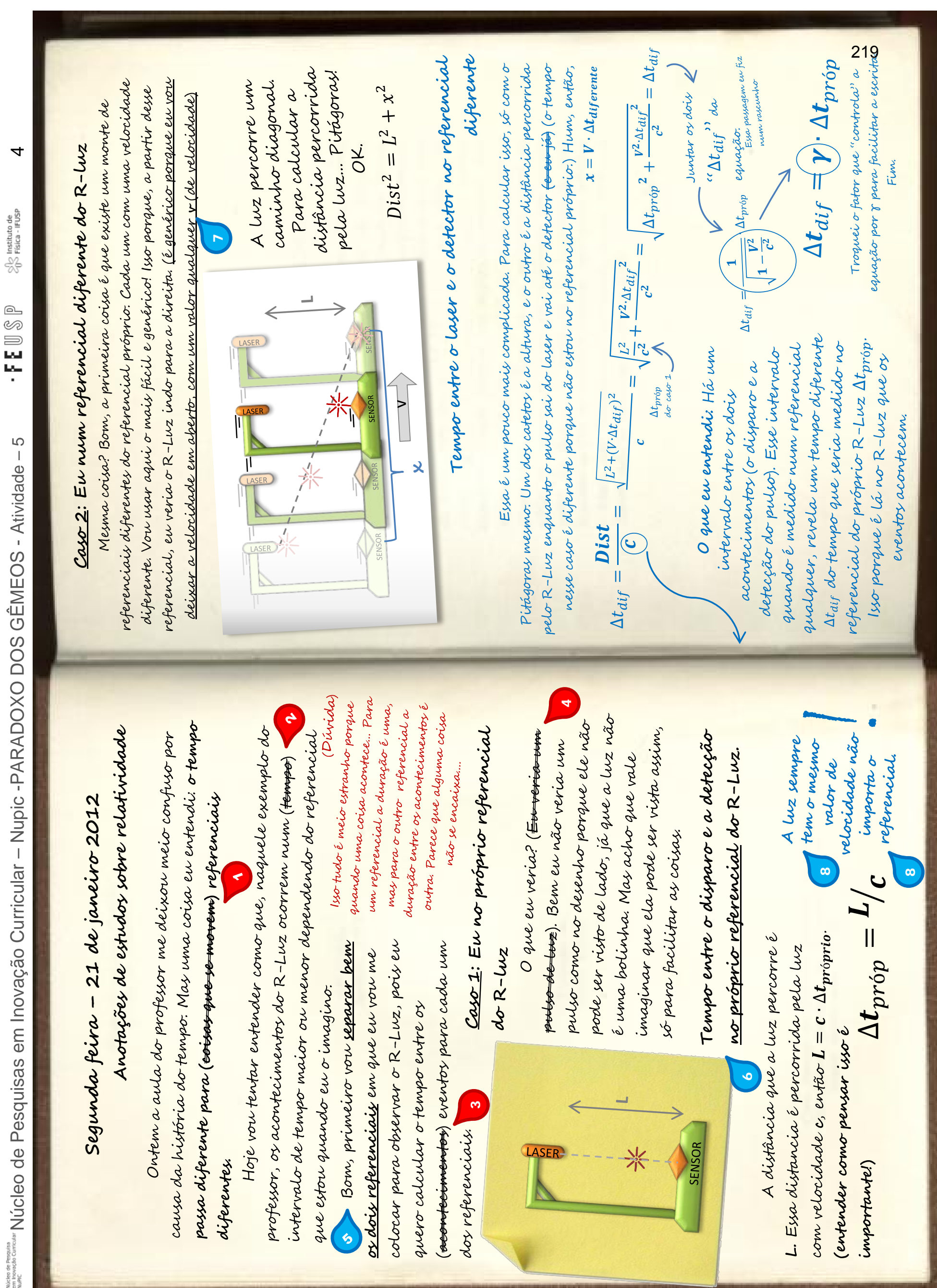


Nome:

Prof.

série:

data:

\section{Atividade 5: R-Luz estudado do referencial próprio e de outro referencial diferente}

1. Pergunte ao se colega: por que a luz não pode ser vista de lado na realidade?

2. Qual a diferença entre os casos 1 e 2, já que é o mesmo R-Luz que está sendo observado? O que significam os intervalos $\Delta t_{\text {dif }}$ e o $\Delta t_{\text {pró }}$ ?

3. Observando a lógica matemática apresentada nas equações do diário, responda por que a duração entre o disparo do pulso e sua detecção num referencial qualquer $\Delta t_{d i f}$ é maior do que o tempo $\Delta t_{\text {próp }}$ medido no próprio referencial do R-Luz?

4. Qual é o valor que $\gamma$ deve ter para que $\Delta t_{\text {dif }}$ seja igual $\Delta t_{\text {próp }}$ ? Para qual velocidade $\gamma$ possui esse valor?

5. O caso 2 possui uma passagem matemática que foi feita em algum rascunho. Refaça todo pensamento lógico do caso 2 indicando matematicamente como esta passagem foi feita. 


\section{Informações para o professor}

\section{Atividade 5: R-Luz estudado do referencial próprio e de outro referencial diferente}

Respostas às questões entregues aos alunos

\section{Pergunte ao seu colega: por que a luz não pode ser vista de lado na realidade?}

Na representação do experimento de pensamento, a luz é tratada como um objeto material comum. Um objeto comum, parado ou se dirigindo a algum lugar, reflete a luz que o ilumina para várias direções, inclusive em direção aos nossos olhos. Por isso o vemos. Essa simplificação facilita o entendimento quanto à trajetória efetuada pela luz no R-Luz, mas cria confusão quanto essência física do pulso luminoso. A luz não pode ser "vista de lado" porque, ao trafegar entre o laser e o sensor, ela não reflete as luzes que iluminam o ambiente. Seria visível somente se os olhos do observador estivessem posicionados na trajetória do pulso e virados para o laser.

Seria interessante tratar essa dificuldade experimental em classe de modo a justificar o uso de experimentos de pensamento para facilitar o entendimento dos fenômenos.

\section{Qual a diferença entre os casos 1 e 2, já que é o mesmo R-Luz que está sendo observado? O que significam os intervalos $\Delta t_{\text {dif }}$ e o $\Delta t_{\text {próp }}$ ?}

Como o experimento de pensamento é montado com poucos elementos, não consideramos que a resposta deva conter elementos a mais dos apresentados sob a desculpa de falta de interpretação do problema. Espera-se que o aluno consiga identificar o movimento do observador, do objeto ou na melhor das hipóteses o movimento relativo como a grande diferença entre os dois casos.

É importante observar que a diferença entre os intervalos não está diretamente associadas ao R-Luz, uma vez que ele é sempre o mesmo em ambos os casos estudados. Na verdade, a diferença está na forma como o observamos o R-Luz: se observarmos o intervalo entre os eventos “disparo” e "deteç̧ão" a partir do referencial do próprio R-Luz, então mediremos $\Delta \boldsymbol{t}_{\text {pró }}$ se observarmos o intervalo de tempo dos mesmos eventos a partir de um referencial diferente, então mediremos $\Delta \boldsymbol{t}_{\text {dif }}$.

3. Observando a lógica matemática apresentada nas equações do diário, responda por que a duração entre o disparo do pulso e sua detecção num referencial qualquer $\Delta t_{d i f}$ é maior do que o tempo $\Delta t_{\text {próp }}$ medido no próprio referencial do R-Luz?

Uma resposta considerada válida tentaria mostrar como a variação da velocidade só permite valores de $\gamma$ menores que 1 ou ainda como o valor $\Delta t_{\text {dif }}$ varia em função da velocidade. Um gráfico simplificado ou mesmo uma descrição verbal sobre tal variação seria suficiente. É importante notar que uma aproximação pode sugerir que a relação com a velocidade seja inversa quando na verdade existe uma relação mais complexa, associada ao inverso da raiz quadrada. Ao lado, o gráfico pode auxiliar o professor.

\section{Qual é o valor que $\gamma$ deve ter para que $\Delta t_{\text {dif }}$ seja igual $\Delta t_{\text {próp }}$ ? Para qual velocidade $\gamma$} possui esse valor?

Gama deverá possuir o valor máximo para que $\Delta t_{\text {dif }}$ seja igual a $\Delta t_{\text {próp }}$, ou seja, $\gamma=1$. A velocidade que torna o valor de gama máximo é igual à zero, ou seja, o tempo $\Delta t_{d i f}$ é igual a $\Delta t_{\text {próp }}$ quando o referencial diferente coincide com o próprio referencial dos eventos. 
5. Pergunte ao se colega: por que a luz não pode ser vista de lado na realidade?

O caso 2 possui uma passagem matemática que foi feita em algum rascunho. Refaça todo pensamento lógico do caso 2 indicando matematicamente como esta passagem foi feita.

Segue abaixo as passagens matemáticas que comporiam o rascunho indicado no diário.

$$
\begin{aligned}
& \Delta t_{\text {dif }}=\frac{\boldsymbol{D} \boldsymbol{i s t}}{\boldsymbol{c}}=\frac{\sqrt{L^{2}+\left(V \cdot \Delta t_{d i f}\right)^{2}}}{\boldsymbol{c}}=\sqrt{\frac{L^{2}}{\boldsymbol{c}^{2}}+\frac{\boldsymbol{V}^{2} \cdot \Delta t_{d i f}^{2}}{\boldsymbol{c}^{2}}}=\sqrt{\Delta t_{\text {próp }}{ }^{2}+\frac{\boldsymbol{V}^{2} \cdot \Delta t_{d i f}^{2}}{\boldsymbol{c}^{2}}} \\
& \Rightarrow \Delta t_{d i f}^{2}=\Delta t_{\text {próp }}^{2}+\frac{V^{2} \cdot \Delta t_{d i f}^{2}}{c^{2}} \\
& \Rightarrow \Delta t_{d i f}^{2}-\frac{V^{2} \cdot \Delta t_{d i f}^{2}}{c^{2}}=\Delta t_{\text {próp }}^{2} \\
& \Rightarrow \Delta t_{d i f}^{2}\left(1-\frac{V^{2}}{c^{2}}\right)=\Delta t_{\text {próp }}^{2} \\
& \Rightarrow \Delta t_{d i f}^{2}=\frac{\Delta t_{\text {próp }}{ }^{2}}{\left(1-\frac{V^{2}}{c^{2}}\right)} \\
& \Rightarrow \Delta t_{d i f}=\sqrt{\frac{\Delta t_{p r o ́ p}^{2}}{\left(1-\frac{V^{2}}{c^{2}}\right)}}=\frac{\Delta t_{p r o ́ p}}{\sqrt{\left(1-\frac{V^{2}}{c^{2}}\right)}} \\
& \Rightarrow \Delta t_{\text {dif }}=\gamma \cdot \Delta t_{\text {próp }}
\end{aligned}
$$




\section{ATIVIDADE 6 - REFERENCIAL PARADOXAL}

\section{OBJETIVO:}

Esta atividade tem por objetivo revelar o paradoxo dos gêmeos para os alunos por meio da inferência sobre estados de movimento de objetos e referenciais.

Avaliar os movimentos no cotidiano é dito como tarefa simples! Em geral, os alunos não se dão conta de que um corpo aparentemente parado pode na verdade esconder velocidades altíssimas, como no caso da Terra. Ninguém atribuiria ao caderno, ou à cadeira na qual estamos sentados neste momento uma velocidade da ordem de $30 \mathrm{Km} / \mathrm{s}$. Isto por que quando tudo está em movimento é como se nada se movesse! Os referenciais são importantes em Física, pois definem o estado de movimento de um corpo. O uso de referenciais em Física diferencia a designação de estados de movimento feitos no dia a dia, daqueles que tem significado físico.

A atividade se apresentará como um jogo onde a meta é ser capaz de inferir o estado de movimento de objetos vistos em vídeos caseiros produzidos pelos alunos. Na impossibilidade dos vídeos serem produzidos pelos próprios alunos, o professor poderá lançar mão de vídeos em anexo a esta atividade ou que ele próprio tenha produzido. A meta final é recolocar o problema dos Gêmeos e mostrar que se o movimento é algo relativo a um referencial, para o irmão que fica na Terra é o Gêmeo na nave quem se move, pois o primeiro assume a superfície terrestre como referencial inercial ${ }^{1}$. Mas para o irmão na nave é seu irmão na Terra quem se move, pois o primeiro toma a nave como referencial inercial. Desta forma, não haveria como explicar o envelhecimento mais lento do irmão astronauta pelo fato dele estar em alta velocidade. Temos aí o paradoxo!

A introdução da noção de referenciais inerciais pode ser usada para rever diversos fenômenos tratados anteriormente onde a definição de movimento acabou sendo tratada de maneira pouco formal.

\section{CONTEÚDO FÍSICO:}

Noção sobre referenciais; velocidade relativa; movimento compartilhado é como nulo.

\section{RECURSOS:}

- Material instrucional para o professor (este)

- Regras para o QUIZ.

- Regras para a produção do vídeo e QUIZ para alunos.

- Vídeos desafio e solução: mola, bola e mundo move (total 6 arquivos de vídeo)

- Vídeos extras produzidos por alunos

- Avaliação local

\footnotetext{
${ }^{1} \mathrm{Na}$ situação não se considera o movimentos orbitais e rotacionais da Terra.
} 


\section{MOMENTOS SUGERIDOS: APROXIMADAMENTE 1 AULA}

A explicação para a construção dos vídeos deve ser feita em aulas anteriores a esta atividade, uma vez que é necessário tempo extraclasse para sua produção. Caso não tenha sido produzidos vídeos pelos alunos em quantidade suficiente, sugerimos a utilização de vídeos extras presentes na pasta "Atv6 Ref Paradox Videos".

\section{QUIZ}

Sugerimos ao professor que organize a sala em grupos e solicite as duas fichas com as palavras OBJETO E CAMERA presente no material anteriormente oferecido. Informe que a aula começa com uma atividade tipo QUIZ, onde o objetivo é responder se a câmera ou o objeto se move em cada vídeo mostrado. São necessários pelo menos 3 vídeos para a realização da atividade. O professor poderá lançar mão de vídeos prontos anexos a esta atividade. Apresente o vídeo numero 1 (aquele do objeto oscilando na mola) e mostre que na primeira parte a resposta correta é OBJETO e na segunda parte a resposta é CÂMERA. Na sequência, escolha outro vídeo e repita a pergunta de modo a promover o jogo com as respostas dadas por meio da apresentação das fichas.

Anote os pontos e aponte um vencedor.

\section{DISCUSSÃO SOBRE REFERENCIAIS COM BASE NOS VÍDEOS}

Para o segundo momento, inicie uma discussão com a seguinte questão: "Por que alguns vídeos foram mais eficientes do que outros em esconder o que estava em movimento?" A ideia é levar os alunos a perceberem que a falta ou a presença de pontos de referências na imagem dificulta/facilita a identificação dos movimentos. Outras perguntas podem auxiliar na condução da discussão:

$\checkmark$ "Como cada grupo escolheu a cena para realizar o vídeo?"

$\checkmark$ "Por que o vídeo XYZ foi o que mais enganou os grupos?"

$\checkmark$ "Qual a técnica para produzir bons vídeos "farsantes"?"

$\checkmark$ "Qual a técnica para desmascarar vídeos farsantes?"

A discussão deve se encaminhar para a relação entre movimento e referencial. Ou seja, que um movimento precisa ser definido em relação a uma referencia. Isto é, TODO MOVIMENTO E RELATIVO. Apresente a definição de referencial caso isto ainda não tenha sido feita para os alunos. Diferencie referenciais quaisquer de referenciais inerciais de modo a mostrar que existem referencias ruins. Use como exemplo o movimento de um ônibus/trem: quando trafegando em linha reta e em movimento uniforme, não percebemos que estamos em movimento. Mas quando ele acelera/desacelera ou faz uma curva seu movimento torna-se perceptível pelo aparecimento de forças/impulsos/ trancos.

Apresente algumas situações onde estar ou não em movimento dependerá da referencial adotado. Por exemplo, use a sala de aula.

$\checkmark$ Exemplo 1: Uma cadeira está parada se o referencial for tomado solidariamente às paredes da sala de aula. Em relação a um referencial no Sol, estará em movimento orbital.

$\checkmark$ Exemplo 2: Um passageiro dentro de um trem está parado em relação ao referencial ligado ao vagão, mas estará em movimento em relação um referencial ligado à estação.

IMPORTANTE 1: a perfeita definição de referenciais inerciais não é algo fundamental nesta atividade. 


\section{APRESENTAÇÃO DO PARADOXO DOS GÊMEOS}

Nesse momento estamos em condições de apresentar o paradoxo presente na situação dos gêmeos. Comece fazendo uma representação (Rep. A) dos gêmeos e da nave espacial na lousa usando um referencial ligado a Terra. Em seguida, faça uma nova representação (REP. B) usando um referencial ligado ao foguete. Promova uma explicação ou discussão sobre o paradoxo dos gêmeos (veja material de apoio).

m

- Sugerimos que o professor monte a seguinte situação com elementos das atividades anteriores. Se for considerada a diferenciação temporal explorado no R-Luz associado à reportagem dos gêmeos da atividade 1. As discussões feitas durante esta atividade poderão induzir os alunos a chegarem num estranho paradoxo:

> Para o irmão Adam que fica na Terra é o Gêmeo Sheldon na nave quem se move, pois o primeiro assume a superfície terrestre como referencial inercial. Mas para o irmão na nave, Sheldon, é seu irmão na Terra quem se move, pois o primeiro toma a nave como referencial inercial. Desta forma, não haveria como explicar o envelhecimento mais lento de Sheldon (irmão astronauta) pelo fato dele estar em alta velocidade. Assim cria-se o paradoxo: a final, quem envelhece mais lentamente? (trecho presente no material de apoio)

As atividade seguintes tratarão do conceito de intervalo relativístico e solucionarão o aparente paradoxo dos gêmeos.

\begin{tabular}{|c|c|}
\hline$m$ & AVALIAÇÃO LOCAL \\
\hline 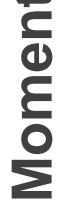 & $\begin{array}{l}\text { Não se esqueça de aplicar a avaliação local nos últimos } 5 \text { minutos. Sugerimos não deixar como } \\
\text { tarefa para casa. }\end{array}$ \\
\hline
\end{tabular}




\section{Atividade Paradoxal}

Você já filmou alguma coisa? Normalmente quando filmamos alguma coisa é muito fácil sabermos se é a coisa ou a câmera que está em movimento, não é mesmo? Veja os vídeos 1 e 2 em sequência e comprove você mesmo como isso pode ser uma mentira!

O seu grupo irá participar de um QUIZ no qual ganha quem fizer mais pontos. Durante o jogo serão apresentados vídeos que gerem dúvidas sobre quem está se movendo: a câmera ou o objeto filmado, ou ainda se a algum deles está ou não em movimento.

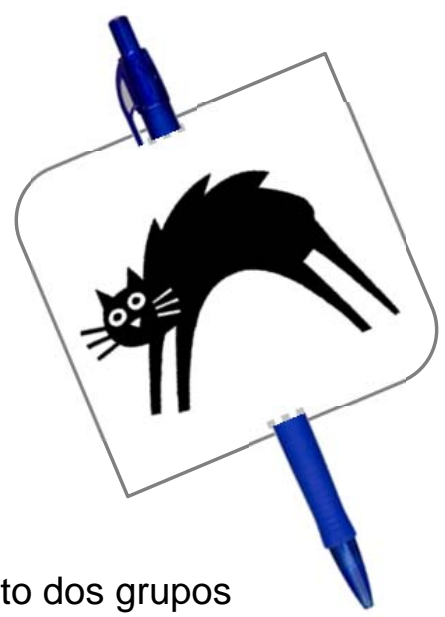

Para ganhar o jogo, o grupo deverá criar um vídeo que atrapalhe o julgamento dos grupos adversários e acertar as questões sobre movimento feitas pelo professor sobre os vídeos feitos por eles.

\section{Regras de confecção dos vídeos:}

- O professor deverá receber dois arquivos de vídeo.

- A gravação deverá ser feita por duas câmeras simultaneamente. A primeira deverá conter o vídeo que confundirá as equipes adversárias, a segunda deverá revelar o modo como foi feito a filmagem a partir dos bastidores (making of). Em último caso serão aceitos arquivos gravados sequencialmente pela mesma câmera.

- Recursos como desajuste do foco, mudanças na iluminação, movimentos falsos ou outras ideias serão aceitos se for mantido o entendimento do vídeo.

- É permitida a edição dos vídeos (cortes, ajustes de cor ou brilho, retirada de bordas, etc)

- A filmagem deve ser real e não é permitida a inclusão de modelagem computacional.

- Vença seus adversários!

Recorte a linha pontilhada
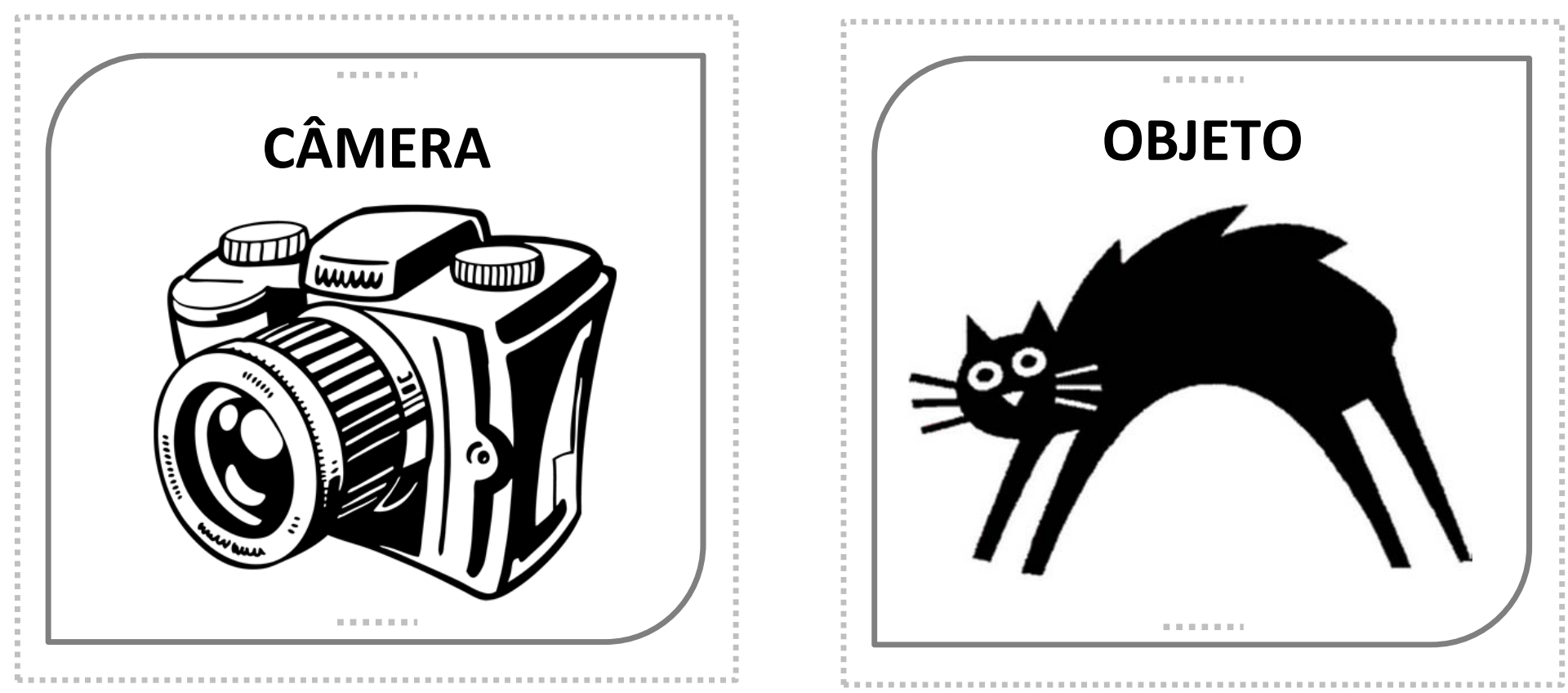


\section{Material de apoio ao professor}

\section{Regras para o QUIZ:}

Cada resposta certa vale 1 ponto para o grupo. Um bônus de 3 pontos será dado ao grupo realizador do vídeo que induziu a classe ao maior numero de erros. Este momento termina com a consagração do grupo vencedor!

\section{Regras de confecção dos vídeos (presente no material do aluno):}

- O professor deverá receber dois arquivos de vídeo.

- A gravação deverá ser feita por duas câmeras simultaneamente. A primeira deverá conter o vídeo que confundirá as equipes adversárias, a segunda deverá revelar o modo como foi feito a filmagem a partir dos bastidores (making of). Em último caso serão aceitos arquivos gravados sequencialmente pela mesma câmera.

- Recursos como desajuste do foco, mudanças na iluminação, movimentos falsos ou outras ideias serão aceitos se for mantido o entendimento do vídeo.

- É permitida a edição dos vídeos (cortes, ajustes de cor ou brilho, retirada de bordas, etc)

- A filmagem deve ser real e não é permitida a inclusão de modelagem computacional.

- Vença seus adversários! 


\section{QUEM ESTÁ JUNTO E QUEM ESTÁ SEPARADO?}

A noção de referencial é abstrata, mas existe uma forma simples de saber se objetos estão ou não no mesmo referencial. Um objeto está no mesmo referencial que outro se não existir velocidade relativa, ou seja, se eles não se moverem entre si. Se uma pessoa está parada na calçada e vê outra pessoa parada na rua, então ambos estão no mesmo referencial. Se um cachorro está parado dentro de um carro em movimento, então tal cachorro está no mesmo referencial do motorista, pois ambos se movem juntos. E não importa a distância, pois um avião em voo pode estar no mesmo referencial de um trem se não existir velocidade relativa entre eles.

Os eventos são considerados absolutos porque uma vez que acontecem, todas as pessoas concordam que ele aconteceu. Isso significa dizer que a existência de um evento é algo que independe do referencial a partir do qual o observamos. Contudo, a descrição dos eventos pode variar de acordo com o referencial.

É comum que os alunos tenham dificuldades quando são comparados os mesmos eventos a partir de referenciais diferentes. Tomemos, por exemplo, a seguinte situação:

\section{Um automóvel anda emparelhado com uma motocicleta a $30 \mathrm{~km} / \mathrm{h}$ na rua Melo Freire.}

Existem vários objetos nessa situação, mas para este exemplo, tomaremos a sequência de eventos criados apenas pelo automóvel. Tais eventos possuem descrições diferentes dependendo do referencial:

- Uma velhinha no referencial da calçada veria o automóvel criando um evento em cada posição e momento ocupados durante seu tráfego pela rua. Para ela, trajetória do automóvel seria uma sequência de eventos espaçados temporalmente e espacialmente por toda a extensão da rua.

- O motociclista que acompanha o carro veria os mesmos eventos que a velhinha, contudo de forma diferente. Para ele os eventos produzidos pelo automóvel ocupariam diferentes coordenadas temporais, mas apenas uma mesma coordenada espacial. Isso porque o carro seria visto sempre no mesmo lugar, ao seu lado, enquanto o tempo passa.

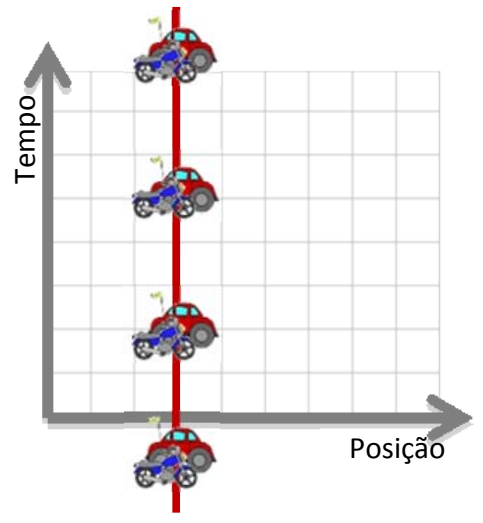

Descrição dos mesmos eventos visto pelo

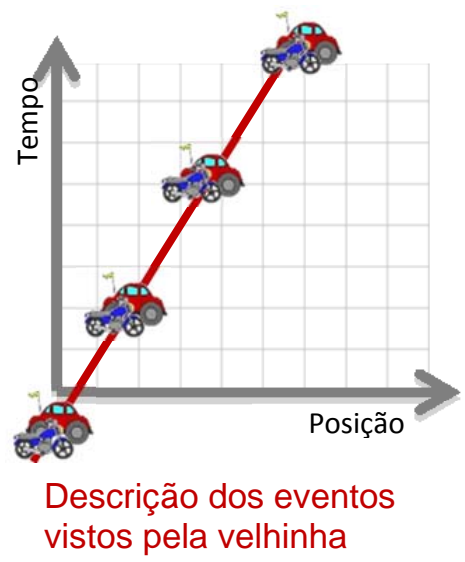

vistos pela velhinha

Observe que a posição dos eixos de tempo e espaço estão invertidas para se adequar à forma de representação comumente utilizada em relatividade e que será utilizada nas atividades seguintes. 


\section{Figura para a explicitação do paradoxo}

Para o irmão Adam que fica na Terra é o Gêmeo Sheldon na nave quem se move, pois o primeiro assume a superfície terrestre como referencial inercial. Mas para o irmão na nave, Sheldon, é seu irmão na Terra quem se move, pois o primeiro toma a nave como referencial inercial. Desta forma, não haveria como explicar o envelhecimento mais lento de Sheldon (irmão astronauta) pelo fato dele estar em alta velocidade. Assim cria-se o paradoxo: a final, quem envelhece mais lentamente?

> Se nos colocarmos no referencial de Adam, na Terra, vemos Sheldon ir embora e voltar. Se nos colocarmos no referencial de Sheldon, na nave, vemos Adam ir embora e voltar. Sendo a situação aparentemente simétrica, como poderiam envelhecer diferentemente? Quem envelhece menos aquele que viaja ou o que fica na Terra?
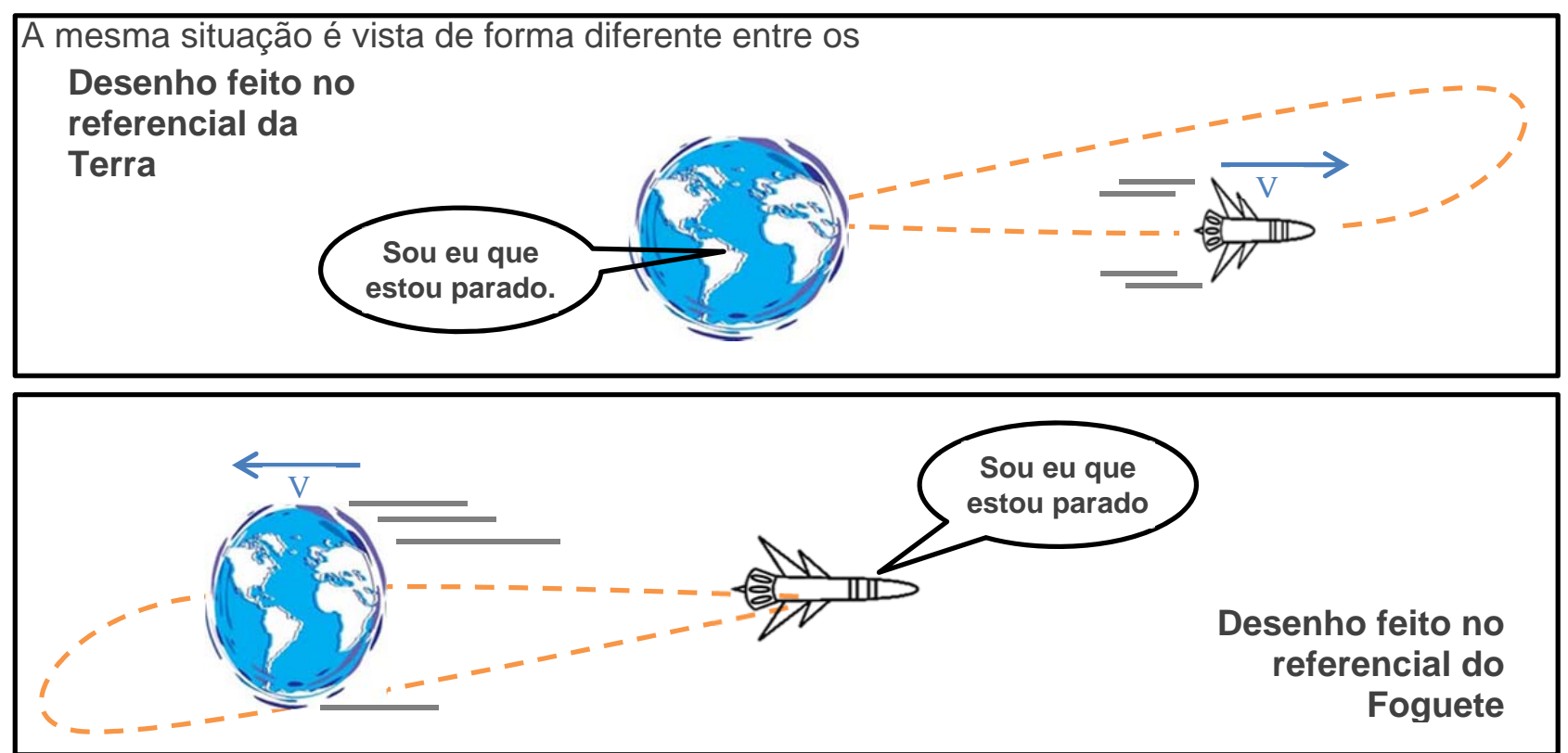


\section{ATIVIDADE 7 - EVENTOS}

\section{OBJETIVO:}

Esta atividade foi desenvolvida para o primeiro contato com o conceito de evento, que consiste em um acontecimento pontual no espaço e no tempo. Como exemplos de eventos, podemos tomar a colisão entre dois carros ou o momento em que pomos nosso pé fora de casa, tais ocorrências bem localizadas no espaço e no tempo podem ser consideradas eventos.

Os eventos são importantes no ensino de relatividade porque eles são absolutos, isto é, permanecem inalterados independentemente de qualquer transformações relativística. Embora diferentes observadores possam descrever diferentemente um evento, podendo por exemplo discordar sobre o momento e o local onde ele ocorreu (suas coordenadas no espaço e no tempo), o fato de o evento ter acontecido não é algo discutível. Este conceito tem papel fundamental na construção do conjunto de noções futuramente trabalhadas.

Esperamos que os alunos consigam ao final da aula extrair onde e quando eventos comuns se manifestam. Para tanto é necessária a compreensão de sua representação no diagrama de espaço e tempo, o qual será importante para a solução de problemas relacionados à diferenciação do tempo. Com maior profundidade esperamos que o aluno compreenda o conceito de evento físico como uma representação abstrata dos acontecimentos no mundo.

É importante que o professor apresente mais alguns elementos que chamem a atenção para a noção de referenciais, mas sem apresentação formal. A noção de referencial vem sendo tratada ao longo do curso e acreditamos que seu significado já esteja sendo construído desde as atividades anteriores.

\section{CONTEÚdO FÍsICO:}

Eventos físicos; representação de eventos; noção sobre referenciais.

\section{MOMENTOS:}

\section{SUGESTÕES}

Inicialmente proponha a formação de pelo menos 5 grupos os quais receberão uma ficha (folha1) a ser preenchida durante a atividade. É importante notar que são necessárias as 5 fichas para que a atividade corra de forma correta, uma vez que elas serão complementares nos momentos seguintes. Inicie contextualizando a atividade, discutindo a noção de evento e referencial (veja o texto de apoio ao professor).

Solicite aos grupos que criem uma história em quadrinhos que represente os principais eventos presentes no depoimento que possuem em mãos respondendo as questões 1A e 1B. Instrua-os a colocarem com a maior aproximação possível informações sobre quando e onde as cenas ocorrem. Para evitar dispender muito tempo neste momento, sugira desenhos icônicos, ou seja, desenhos simples que simbolizam as situações uma vez que nos momentos seguintes eles deverão reproduzi-los na lousa e a qualidade dos desenhos devem ser apenas suficiente para o entendimento.

Sugerimos que o professor aproveite o tempo de confecção dos quadrinhos para a organização da lousa em 5 setores onde os alunos deverão reproduzir os eventos presentes nos depoimentos. O professor poderá reservar um $6^{\circ}$ setor maior para posteriormente construir junto aos alunos o diagrama de espaço e tempo dos acontecimentos (ainda não é um diagrama espaço-temporal relativístico). 


\section{SUGESTÕES}

Para o segundo momento, sugerimos que os alunos, após determinado tempo ou conforme terminam seus desenhos em grupo, reproduzam na lousa os eventos considerados em suas fichas.

Peça, então, que cada grupo leia seu depoimento explicando aos demais não só os desenhos feitos, mas também quando e onde tais eventos ocorreram. Sugerimos ao professor que enfatize as coordenadas temporais e espaciais de cada evento no intuito de chamar a atenção para a reconstrução do acidente que será feita. Ao término dessa etapa, o professor pode fazer uma explicação formal sobre o que é um evento para a física, assim como os erros comuns em conceituá-lo, com base nos desenhos.

\section{SUGESTÕES}

Nesse momento, o professor poderá reconstruir a situação do acidente

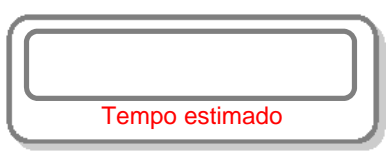
com base nos desenhos sempre dialogando com os alunos.

É importante sistematizar a noção de evento distinguindo e corrigindo os desenhos que representem movimentos distribuídos no tempo ou no espaço (conjuntos de eventos). Nesta atividade, uma boa representação de evento pode ser entendida como uma fotografia que contém com alguma exatidão tanto a posição quanto o momento em que ocorreram os eventos a que se relacionam. Não seriam boas representações aquelas que se utilizem de diagramas, mapas ou elementos dinâmicos nos desenhos.

Como tal reconstrução deverá ser feita de modo a explicar como se interpreta um diagrama de espaço e tempo, sugerimos que o professor desenhe o diagrama apresentando a forma de leitura dos eixos e suas unidades (os quais são invertidos com relação aos eixos normalmente utilizados no ensino de cinemática ou dinâmica clássica). Uma estratégia interessante é iniciar desenhando os elementos fixos presentes na situação, tais como a rua, o bar, a esquina e os personagens que estão no mesmo referencial da rua. Talvez seja interessante explorar noções sobre referenciais apontando quais objetos estão no referencial do chão e quais não estão. Observar que toda a representação encontra-se no referencial da rua.

Depois, desenhe os objetos que estão em outros referenciais revelando os principais eventos relacionados ao acidente com base nas informações dos quadrinhos feitos pelos alunos. Descarte eventos que não são importantes para construir o diagrama (veja o material de sistematização).

Finalmente, explore as sequências de eventos que levaram ao acidente com base nas linhas de mundo relativas ao bar, ao motoboy e ao automóvel vermelho, deixe o automóvel branco para a atividade dos alunos. Consideramos importante a exploração do significado da linha de mundo no diagrama porque os alunos podem apresentar uma interpretação oscilante, considerando erroneamente as trajetórias apresentadas durante a atividade como caminhos percorridos num simples plano espacial. Uma importante diferença entre os dois é que o diagrama de espaço e tempo permite a representação da sequência em que os eventos ocorrem. Tal reconstrução será base do entendimento do diagrama espaço-temporal relativístico que trataremos em atividades futuras.

\section{SUGESTÕES}

Entregue a folha 2 aos grupos para que os alunos respondam as

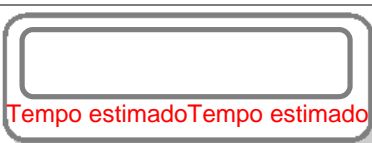
questões propostas. O objetivo é que eles representem por si mesmos eventos no diagrama. Ao final da aula, finalize a investigação com o texto Cena do ponto de vista do falecido: memórias póstumas. 


\section{Atividade 7 - Eventos: Grupo A}

$\mathrm{Na}$ aula de hoje vamos ajudar uma equipe de investigadores da polícia civil a descobrir qual foi a causa de um acidente ocorrido ontem à noite. $\mathrm{O}$ acidente aconteceu entre dois carros em um cruzamento movimentado e um dos motoristas, Sr. Brás Cubas, infelizmente faleceu no local.

Para nossa investigação, teremos que fazer uma reconstrução cronológica indicando onde e quando os principais eventos aconteceram. O local estava cheio de pessoas, mas apenas 5 delas sabiam com alguma precisão algo sobre o acidente e deram depoimentos à policia. Cada grupo de investigadores atendeu uma das testemunhas.
Nomes:

Prof

série:

\section{GRUPO A - A Motorista que estava no carro branco}

Saí do trabalho e dirigi alguns minutos tranquilamente pela rua Melo Freire ouvindo rádio. Parei no mercado que fica logo depois do Bar do Zé lá pelas 17h50 e gastei uns 6 minutos comprando leite e outras coisas para tomar café no dia seguinte. Dirigi em direção ao cruzamento, mas o semáforo estava vermelho para quem ia entrar à esquerda. Acho que o semáforo estava quebrado porque esperei uns 2 minutos antes que ele abrisse. Quando o farol ficou verde, eu virei para a esquerda e logo ocorreu a batida. O carro vermelho estava logo atrás, mas eu não o vi pelo retrovisor. Fiquei tonto com o impacto e cheguei a pensar que tinha morrido quando escutei o relógio da igreja badalando. Só dei conta do ocorrido umas 18:05 quando o resgate chegou.

1A - Leiam o depoimento acima e desenhem uma história em quadrinhos simplificada, indicando com a maior precisão possível onde e quando os principais eventos ocorreram (utilize quantos quadrinhos achar necesssário). Em seguida apresente a reconstrução do seu depoimento para a turma.

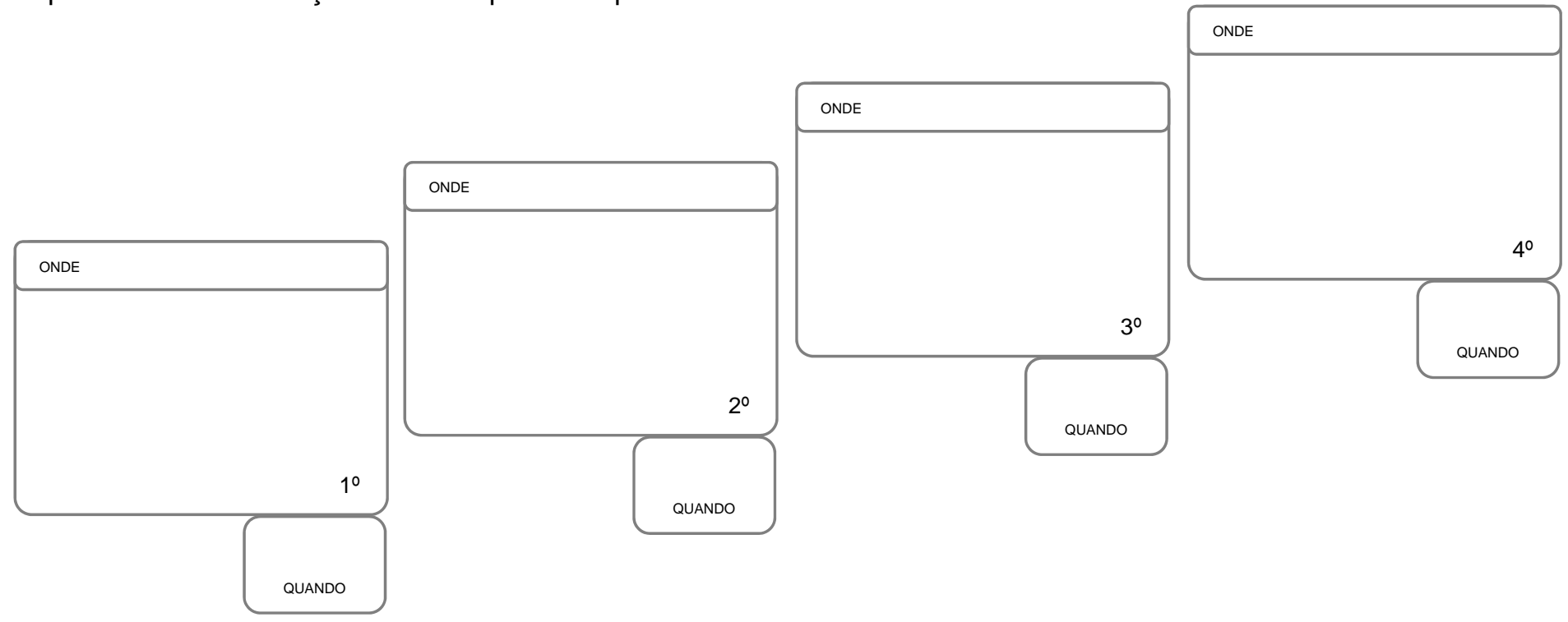

Hora:

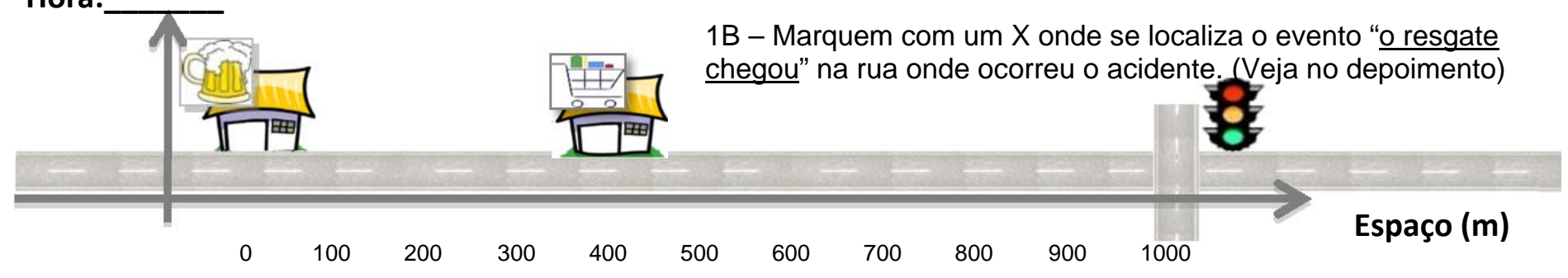




\section{Atividade 7 - Eventos: Grupo B}

$\mathrm{Na}$ aula de hoje vamos ajudar uma equipe de investigadores da polícia civil a descobrir qual foi a causa de um acidente ocorrido ontem à noite. $\mathrm{O}$ acidente aconteceu entre dois carros em um cruzamento movimentado e um dos motoristas, Sr. Brás Cubas, infelizmente faleceu no local.

Para nossa investigação, teremos que fazer uma reconstrução cronológica indicando onde e quando os principais eventos aconteceram. O local estava cheio de pessoas, mas apenas 5 delas sabiam com alguma precisão algo sobre o acidente e deram depoimentos à policia. Cada grupo de investigadores atendeu uma das testemunhas.
Nomes:

Prof.

série:

\section{GRUPO B - O Mendigo}

Todo dia, eu chego dez minutos antes das $18 \mathrm{~h} 00$ aqui no cruzamento, onde os carros param. Sabe como é, o movimento aumenta nesse horário dá para arrecadar algum dinheiro. Eu estava voltando do banheiro $17 \mathrm{~h} 59$ quando vi que o carro vermelho fechou um motoboy a uns 400 metros daqui. Depois o motorista veio ziguezagueando não muito rápido enquanto falava no celular com uma cara bem desconcertada. Ele nem freou e arrebentou o carro branco que estava virando aqui na esquina. Isso foi bem na hora que o relógio da igreja tocava. Depois de uns 5 minutos o resgate chegou.

1A - Leiam o depoimento acima e desenhem uma história em quadrinhos simplificada, indicando com a maior precisão possível onde e quando os principais eventos ocorreram (utilize quantos quadrinhos achar necesssário). Em seguida, apresente a reconstrução do seu depoimento para a turma.

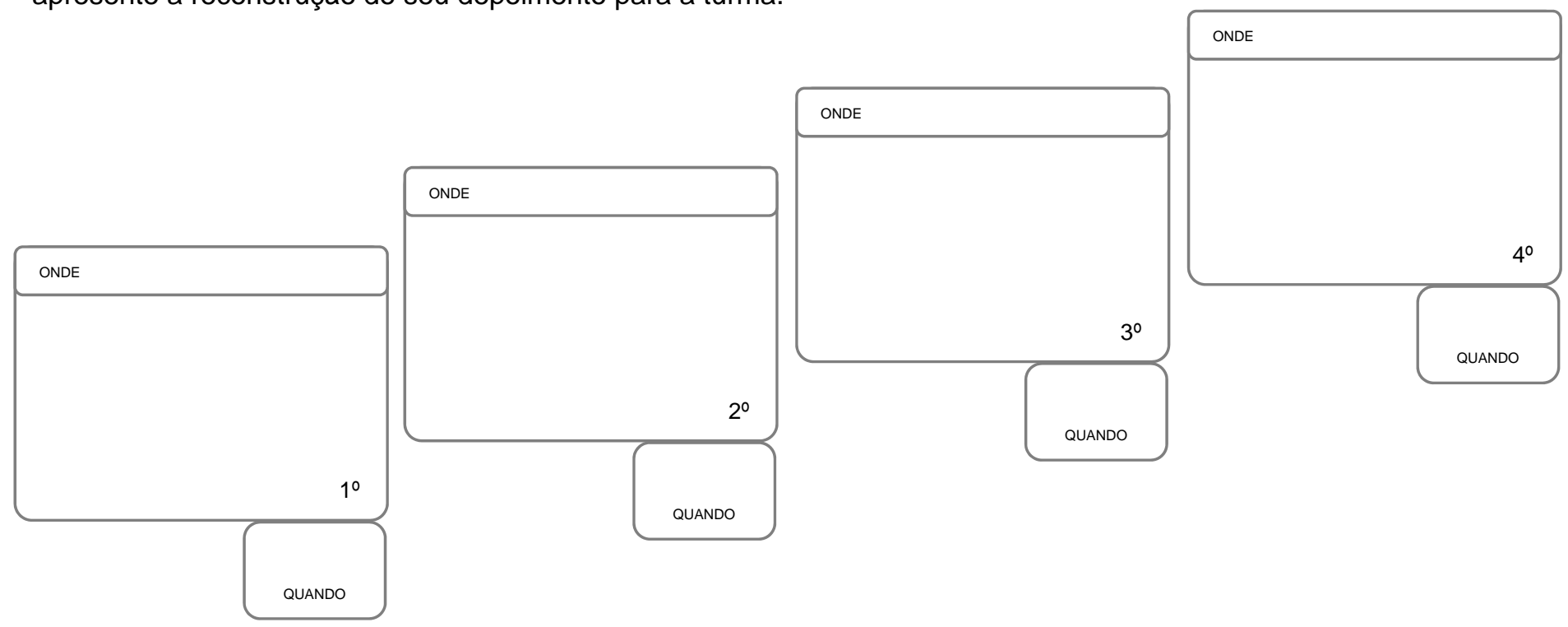

Hora:

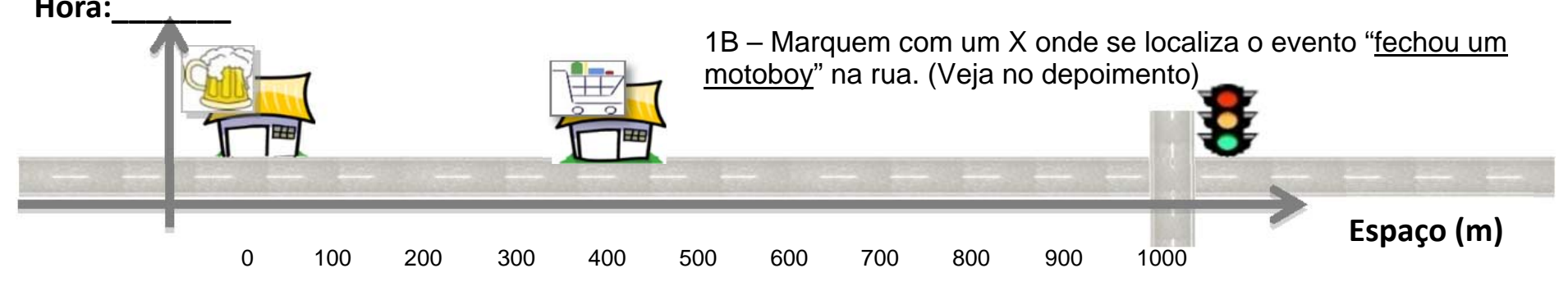




\section{Atividade 7 - Eventos: Grupo C}

$\mathrm{Na}$ aula de hoje vamos ajudar uma equipe de investigadores da polícia civil a descobrir qual foi a causa de um acidente ocorrido ontem à noite. $\mathrm{O}$ acidente aconteceu entre dois carros em um cruzamento movimentado e um dos motoristas, Sr. Brás Cubas, infelizmente faleceu no local.

Para nossa investigação, teremos que fazer uma reconstrução cronológica indicando onde e quando os principais eventos aconteceram. O local estava cheio de pessoas, mas apenas 5 delas sabiam com alguma precisão algo sobre o acidente e deram depoimentos à policia. Cada grupo de investigadores atendeu uma das testemunhas.
Nomes:

Prof.

série:

\section{GRUPO C - A Velhinha}

Já era um pouco tarde, mas todos os dias eu chego às $17 \mathrm{~h} 55$ eu fico ali próximo do Supermercado, na rua Melo Freire, esperando meu neto voltar da escola. Foi quando eu vi aquele carro vermelho acompanhando a motocicleta. Havia alguma coisa errada com o motorista porque ele estava com os olhos esbugalhados e boquiaberto. Ele andou uns 200 metros e fechou o motoboy que se salvou com uma freada brusca. Meu neto chegou $18 \mathrm{~h} 01$ e fomos para casa. Quando passamos na esquina, havia um grande tumulto por causa do acidente. Meu neto tirou uma fotografia com o celular dos bombeiros resgatando os feridos. (Fotografia batida 18h06)

1A - Leiam o depoimento acima e desenhem uma história em quadrinhos simplificada, indicando com a maior precisão possível onde e quando os principais eventos ocorreram (utilize quantos quadrinhos achar necesssário). Em seguida apresente a reconstrução do seu depoimento para a turma.

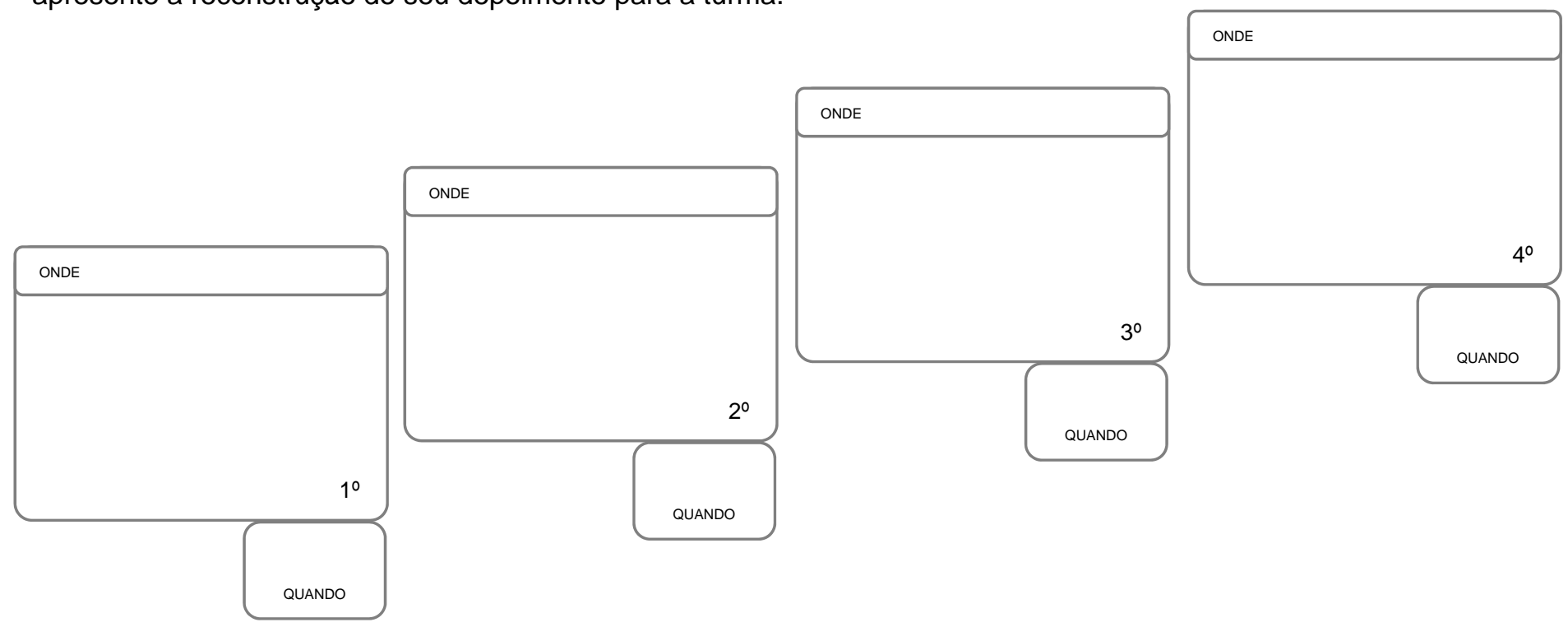

Hora:

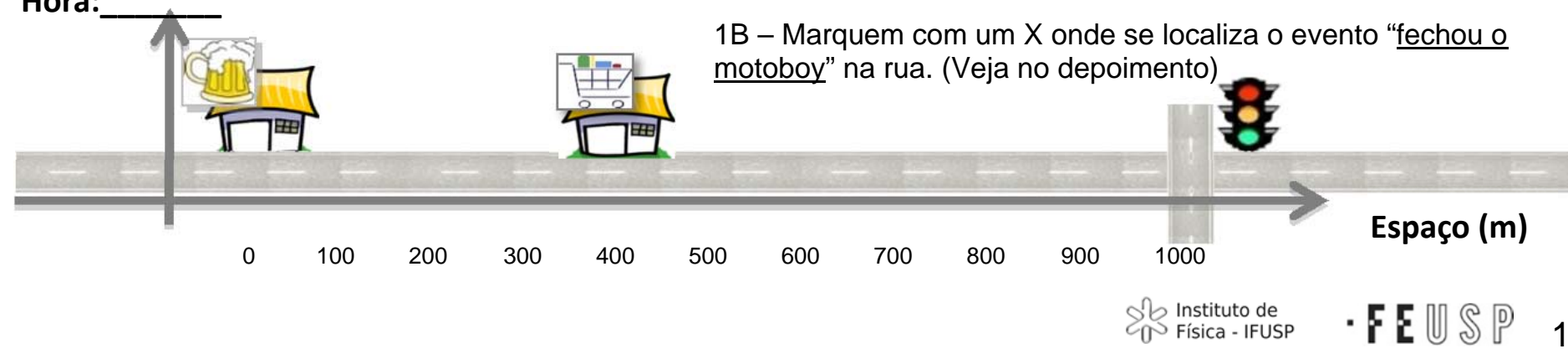




\section{Atividade 7 - Eventos: Grupo D}

$\mathrm{Na}$ aula de hoje vamos ajudar uma equipe de investigadores da polícia civil a descobrir qual foi a causa de um acidente ocorrido ontem à noite. $\mathrm{O}$ acidente aconteceu entre dois carros em um cruzamento movimentado e um dos motoristas, Sr. Brás Cubas, infelizmente faleceu no local.

Para nossa investigação, teremos que fazer uma reconstrução cronológica indicando onde e quando os principais eventos aconteceram. O local estava cheio de pessoas, mas apenas 5 delas sabiam com alguma precisão algo sobre o acidente e deram depoimentos à policia. Cada grupo de investigadores atendeu uma das testemunhas.
Nomes:

Prof.

série:

\section{GRUPO D - O Motoqueiro}

Eu saí para entregar uma pizza e para não perder a venda eu estava andando rápido. Bem na frente do Bar do Zé, o maluco do carro vermelho emparelhou comigo fazendo com que eu reduzisse bastante a velocidade e pilotasse lado a lado durante 1 minuto. Foi aí que o cara me fechou e por pouco não virei estatística. A fechada foi exatamente às $17 \mathrm{~h} 59$ a uns $400 \mathrm{~m}$ da esquina. Não demorou muito para que eu ouvisse o barulho da batida. Liguei para o resgate imaginando que o pior havia acontecido e esperei um pouco a adrenalina baixar antes de ir ver o acidadente. $\mathrm{O}$ resgate chegou uns 4 minutos depois da minha ligação. (o resgate confirmou a ligação às 18h01).

$1 \mathrm{~A}$ - Leiam o depoimento acima e desenhem uma história em quadrinhos simplificada, indicando com a maior precisão possível onde e quando os principais eventos ocorreram (utilize quantos quadrinhos achar necesssário). Em seguida apresente a reconstrução do seu depoimento para a turma.

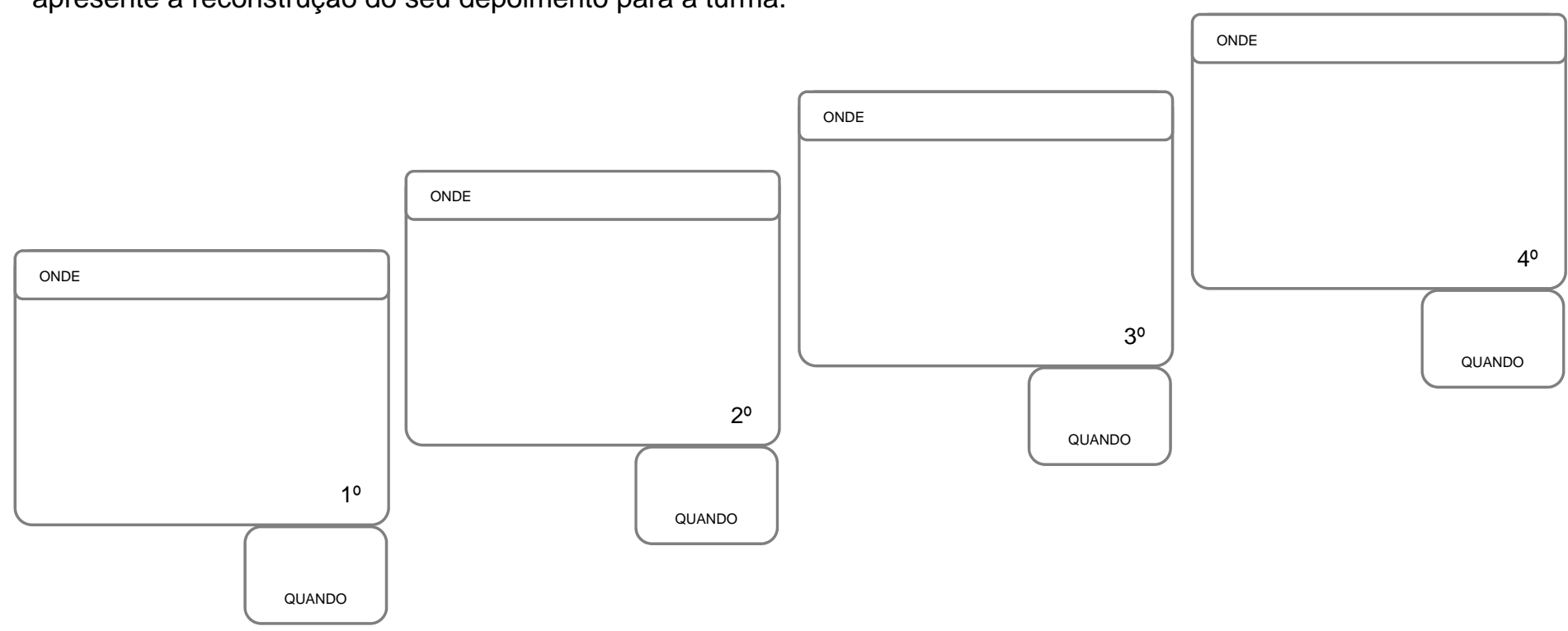

Hora:

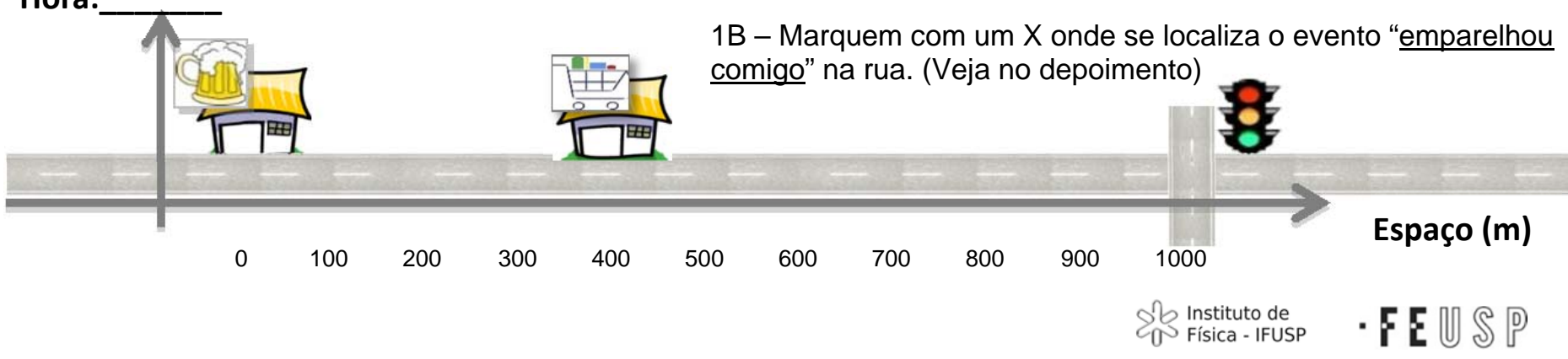




\section{Atividade 7 - Eventos: Grupo E}

$\mathrm{Na}$ aula de hoje vamos ajudar uma equipe de investigadores da polícia civil a descobrir qual foi a causa de um acidente ocorrido ontem à noite. $\mathrm{O}$ acidente aconteceu entre dois carros em um cruzamento movimentado e um dos motoristas, Sr. Brás Cubas, infelizmente faleceu no local.

Para nossa investigação, teremos que fazer uma reconstrução cronológica indicando onde e quando os principais eventos aconteceram. O local estava cheio de pessoas, mas apenas 5 delas sabiam com alguma precisão algo sobre o acidente e deram depoimentos à policia. Cada grupo de investigadores atendeu uma das testemunhas.
Nomes:

Prof.

série:

\section{GRUPO E - Depoimento do Barman:}

Todo dia as $17 \mathrm{~h} 55$ eu assisto ao "Meu boteco, minha vida" na TV aqui no meu estabelecimento. Um minuto depois do programa começar, entrou um cara olhando para todos os lados como se estivesse sendo perseguido. Então ele encostou no balcão e pediu uma água todo afobado parecendo estar doidão. Mais ou menos dois minutos depois ele voltou cambaleando para o carro vermelho. Vendo aquela situação, eu corri atras dele para tentar impedi-lo de dirigir drogado e causar um acidente. Mas não consegui e quando cheguei na rua ele já estava dirigindo. O pior é que eu tinha razão porque passou só um minuto e eu pude ver, bem ao longe, que o maluco fechou uma moto a uns 600 metros daqui, depois do Supermercado. Espero que o motoboy esteja bem...

$1 \mathrm{~A}$ - Leiam o depoimento acima e desenhem uma história em quadrinhos simplificada, indicando com a maior precisão possível onde e quando os principais eventos ocorreram (utilize quantos quadrinhos achar necesssário). Em seguida apresente a reconstrução do seu depoimento para a turma.

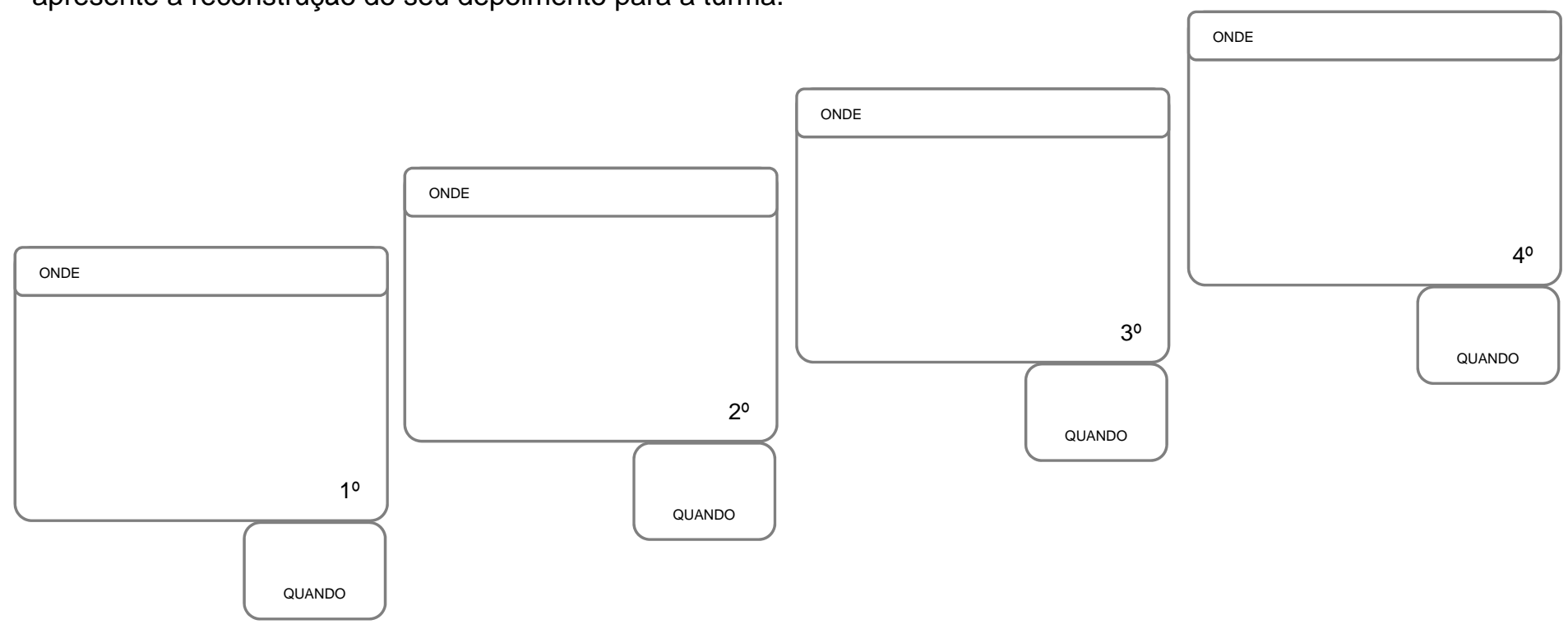

Hora:

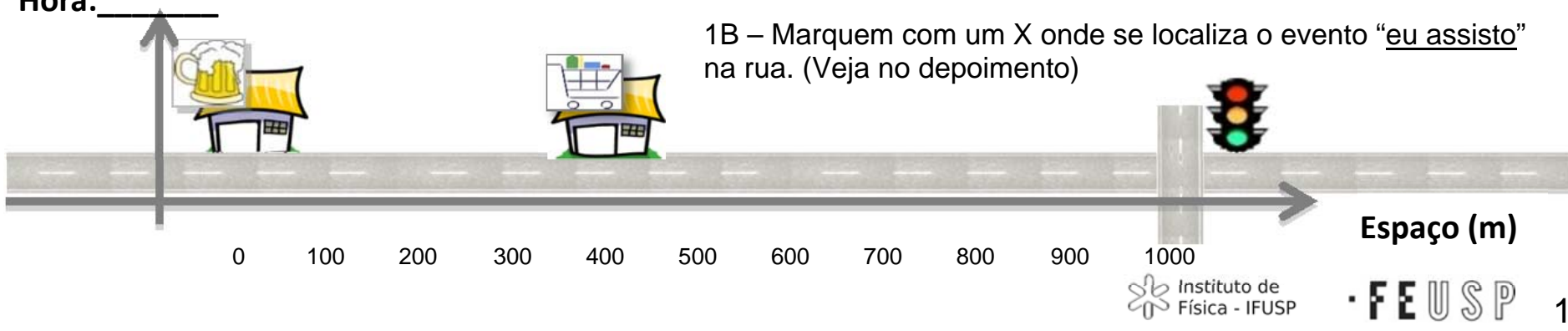




\section{Atividade 7 - Eventos e Referenciais (folha 2)}

2 - Olhe os eventos desenhados nos quadrinhos acima e localize-os com $X$ no diagrama abaixo.

3 - Com base em todos os depoimentos localize os eventos abaixo desenhando no diagrama o percurso espaço temporais da vítima do carro vermelho e do motorista do carro branco.
Nomes:

Prof.

série:

data:

\begin{tabular}{|l|c|c|}
\hline \multicolumn{1}{|c|}{ Eventos } & $\begin{array}{c}\text { Onde } \\
\text { (posição) }\end{array}$ & $\begin{array}{c}\text { Quando } \\
\text { (tempo) }\end{array}$ \\
\cline { 1 - 1 } Motorista do carro vermelho sai dirigindo do Bar do Zé & & \\
\cline { 1 - 1 } Motoboy encontra carro vermelho & & \\
\hline Motorista do carro vermelho fecha motoboy & & \\
\hline Motorrista do carro vermelho bate no automóvel branco & & \\
\hline Motorista do carro branco entra no mercado & & \\
\hline Motorista do carro branco sai do mercado & & \\
\hline
\end{tabular}
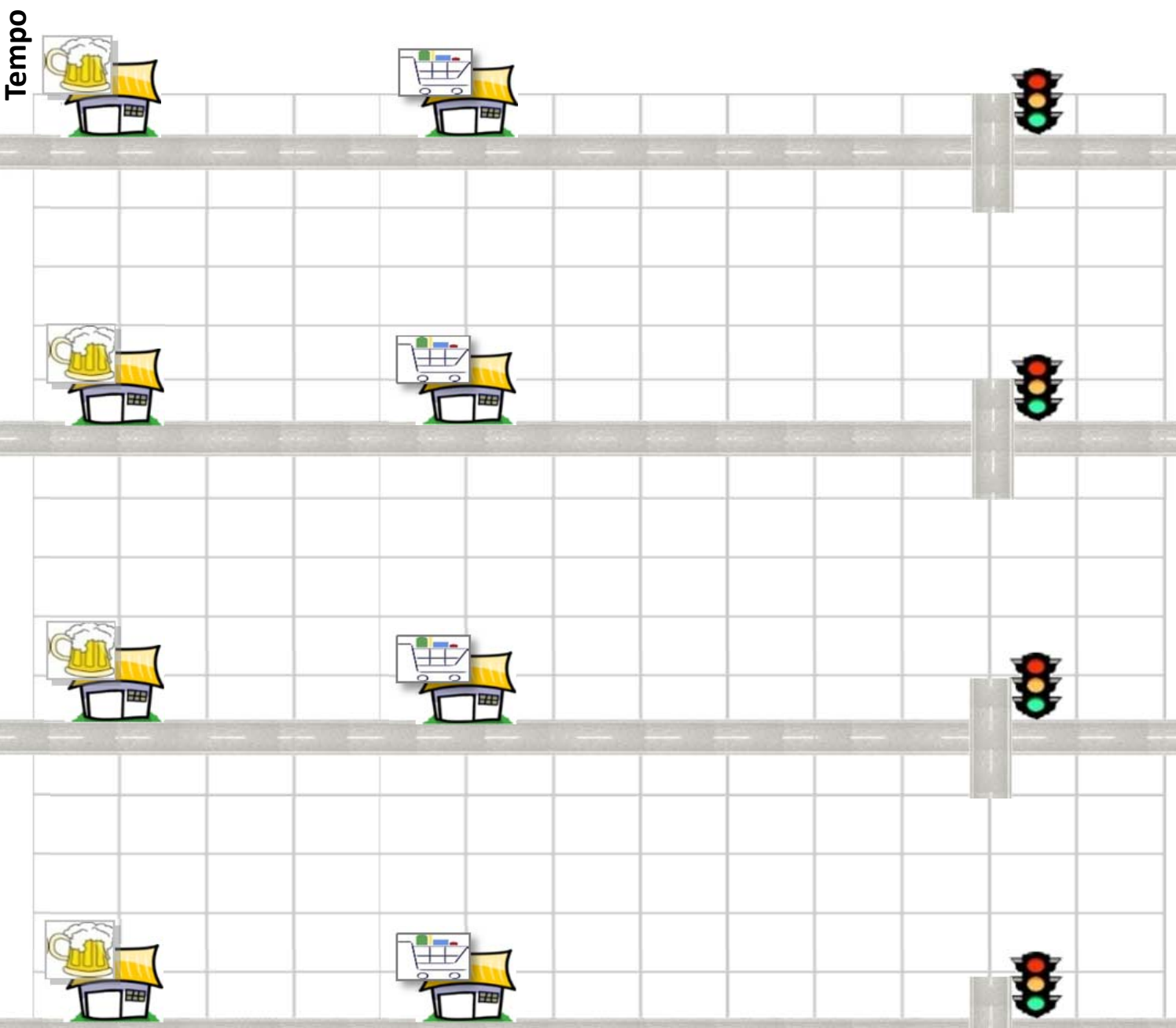

I

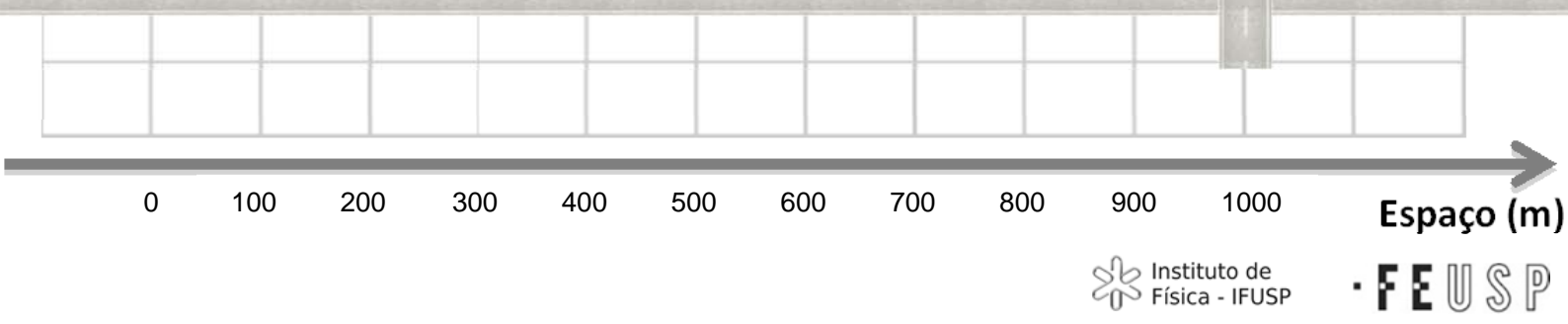




\section{Atividade 7 - Eventos - Texto de apoio}

Existem muitas formas de abordar os conceitos físicos de referencial e evento. Neste texto procuramos apresentar a linha de raciocínio que sugerimos para tal abordagem.

\section{EM QUE LUGAR E EM QUE MOMENTO?}

Ao longo das nossas vidas vivenciamos e observamos vários eventos, os quais nos referimos dizendo sempre em que local e em que momento eles aconteceram: o nosso primeiro beijo foi no cinema no dia 2 de outubro, eu peguei o ônibus 7h45 no centro da cidade. Para simplificar as coisas, representamos os eventos apenas com suas coordenadas de tempo (sabendo a hora em que ocorreu) e a posição (sabendo onde o evento ocorreu).

\section{O evento é a representação física de um acontecimento qualquer no universo.}

$1^{\circ}$ beijo (cinema ; 02/10)

Subiu no ônibus (centro; 7h45)

Às vezes um evento é confundido com uma sequência de eventos no nosso dia a dia. Como exemplo de um único evento, podemos imaginar um pingo no "i" quando estamos escrevendo, pois ele acontece em um momento e em um ponto no espaço. Por outro lado, a escrita de um texto é um conjunto imenso de eventos, uma vez que ocupa diversas posições em diversos momentos diferentes.

Objetos como uma caneca ou um carro passando na rua criam eventos de forma contínua no universo. Assim, quando vemos uma caneca sobre uma mesa estamos presenciando uma linha de eventos, pois apesar da caneca permanecer parada, ela ocupa diferentes posições no tempo. Da mesma forma, quando um carro passa por uma rua, ele também gera uma linha contínua de eventos, mas que agora se diferenciam não só no tempo como no espaço. O nome linha de mundo é dado a toda sequência de eventos produzidas pela existência de um objeto em movimento ou parado no universo.

É importante observar que estamos num momento da sequência didática intermediário entre as representações clássicas e representações relativísticas. Assim, para abordarmos a noção de evento, optamos por uma atividade que se utiliza de elementos relativísticos tais como eventos e linha de mundo, mas ainda mantemos a representação num diagrama clássico. A rigor a linha de mundo repousa sobre um gráfico espaço-temporal (normalmente quadridimensional, com 3 eixos espaciais e 1 temporal) o qual exige uma interpretação diferenciada dos tradicionais gráficos utilizados em física clássica. Dentre outras, uma grande diferença está no eixo temporal que, por meio da união do espaço com o tempo, possui unidade de espaço uma vez que a unidade usada no eixo temporal é o tempo multiplicado pela velocidade da luz (ct).

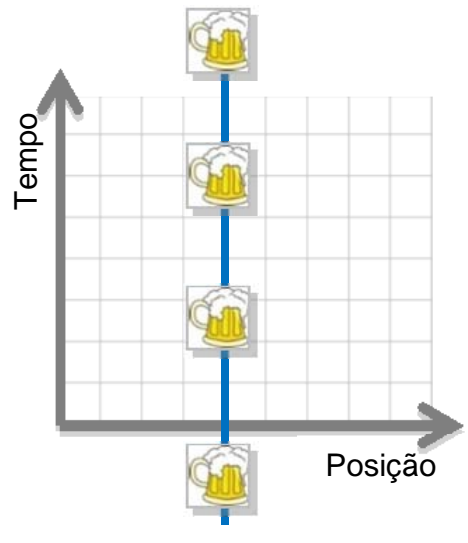

Linha de mundo da caneca parada sobre a mesa

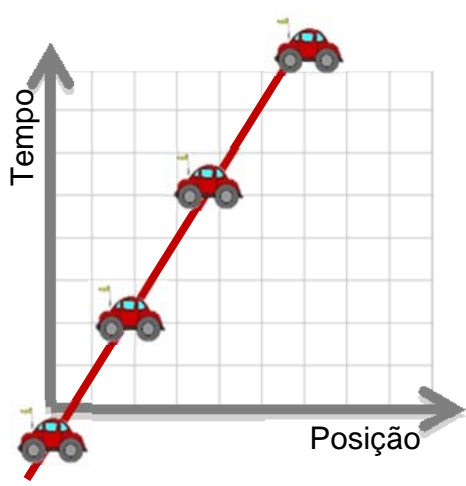

Linha de mundo do carro passando pela rua com velocidade constante 


\section{QUEM ESTÁ JUNTO E QUEM ESTÁ SEPARADO?}

A noção de referencial é abstrata, mas existe uma forma simples de saber se objetos estão ou não no mesmo referencial. Um objeto está no mesmo referencial que outro se não existir velocidade relativa, ou seja, se eles não se moverem entre si. Se uma pessoa está parada na calçada e vê outra pessoa parada na rua, então ambos estão no mesmo referencial. Se um cachorro está parado dentro de um carro em movimento, então tal cachorro está no mesmo referencial do motorista, pois ambos se movem juntos. E não importa a distância, pois um avião em vôo pode estar no mesmo referencial de um trem se não existir velocidade relativa entre eles.

Os eventos são considerados absolutos porque uma vez que acontecem, todas as pessoas concordam que ele aconteceu. Isso significa dizer que a existência de um evento é algo que independe do referencial a partir do qual o observamos. Na investigação da atividade, por exemplo, todos concordavam que o motoboy havia tomado uma fechada e que, em seguida, ocorreu a batida. Contudo, a descrição dos eventos pode variar de acordo com o referencial.

É comum que os alunos tenham dificuldades quando são comparados os mesmos eventos a partir de referenciais diferentes. Tomemos, por exemplo, a seguinte situação:

\section{Um automóvel anda emparelhado com uma motocicleta a $30 \mathrm{~km} / \mathrm{h}$ na rua Melo Freire.}

Existem vários objetos nessa situação, mas para este exemplo, tomaremos a sequência de eventos criados apenas pelo automóvel. Tais eventos possuem descrições diferentes dependendo do referencial:

- Uma velhinha no referencial da calçada veria o automóvel criando um evento em cada posição e momento ocupados durante seu tráfego pela rua. Para ela, a linha de mundo do automóvel seria uma sequência de eventos espaçados temporalmente e espacialmente por toda a extensão da rua.

- $\quad$ O motociclista que acompanha o carro veria os mesmos eventos que a velhinha, contudo de forma diferente. Para ele os eventos produzidos pelo automóvel ocupariam diferentes coordenadas temporais, mas apenas uma mesma coordenada espacial. Isso porque o carro seria visto sempre no mesmo lugar, ao seu lado, enquanto o tempo passa.
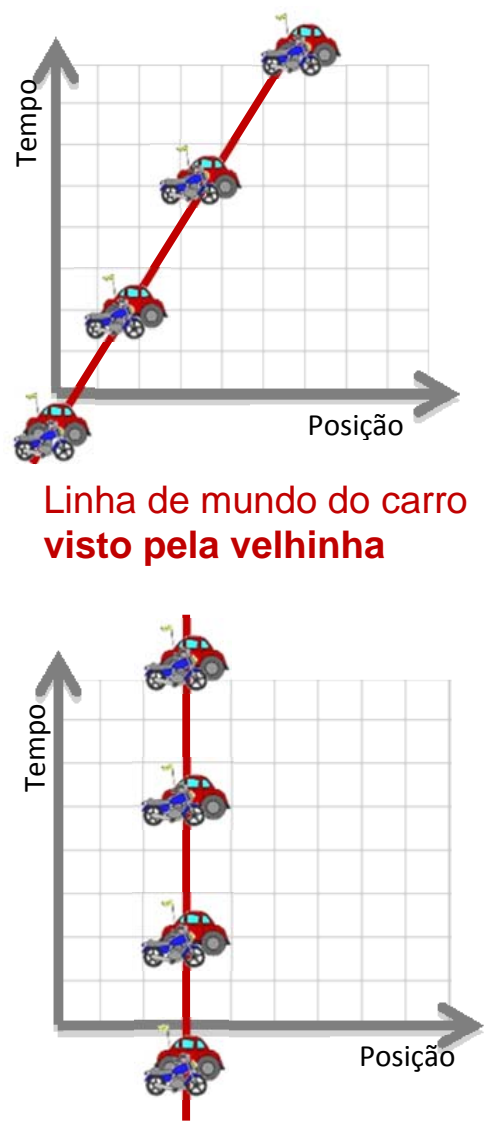

Linha de mundo do carro visto pelo motoqueiro 


\section{Atividade 7 - Eventos - Sistematização da aula}

\section{CONSTRUÇÃO DOS PRINCIPAIS EVENTOS NO DIAGRAMA}

Os alunos terão como tarefa construir o percurso espaçotemporal do motorista do carro branco tendo como exemplo a construção do percurso do carro vermelho. Assim, durante a sistematização dos desenhos frise os eventos sobreados na tabela abaixo.

\begin{tabular}{||l|c|c||}
\hline \multicolumn{2}{|c|}{ Principais eventos } \\
\hline \multicolumn{1}{|c|}{ Eventos } & $\begin{array}{c}\text { Onde } \\
\text { (posição) }\end{array}$ & $\begin{array}{c}\text { Quando } \\
\text { (tempo) }\end{array}$ \\
\cline { 1 - 1 } Motorista do carro vermelho sai dirigindo do Bar do Zé & $0 \mathrm{~m}$ & $17 \mathrm{~h} 58$ \\
\hline Motoboy encontra carro vermelho & $600 \mathrm{~m}$ & $17 \mathrm{~h} 59$ \\
\hline Motorista do carro vermelho fecha motoboy & $1000 \mathrm{~m}$ & $18 \mathrm{~h} 00$ \\
\hline Motorrista do carro vermelho bate no automóvel branco & $400 \mathrm{~m}$ & $17 \mathrm{~h} 50$ \\
\hline Motorista do carro branco entra no mercado & $400 \mathrm{~m}$ & $17 \mathrm{~h} 56$ \\
\hline Motorista do carro branco sai do mercado & & \\
\hline
\end{tabular}

Diagrama sugerido para ser construído na lousa como auxílio ao professor.

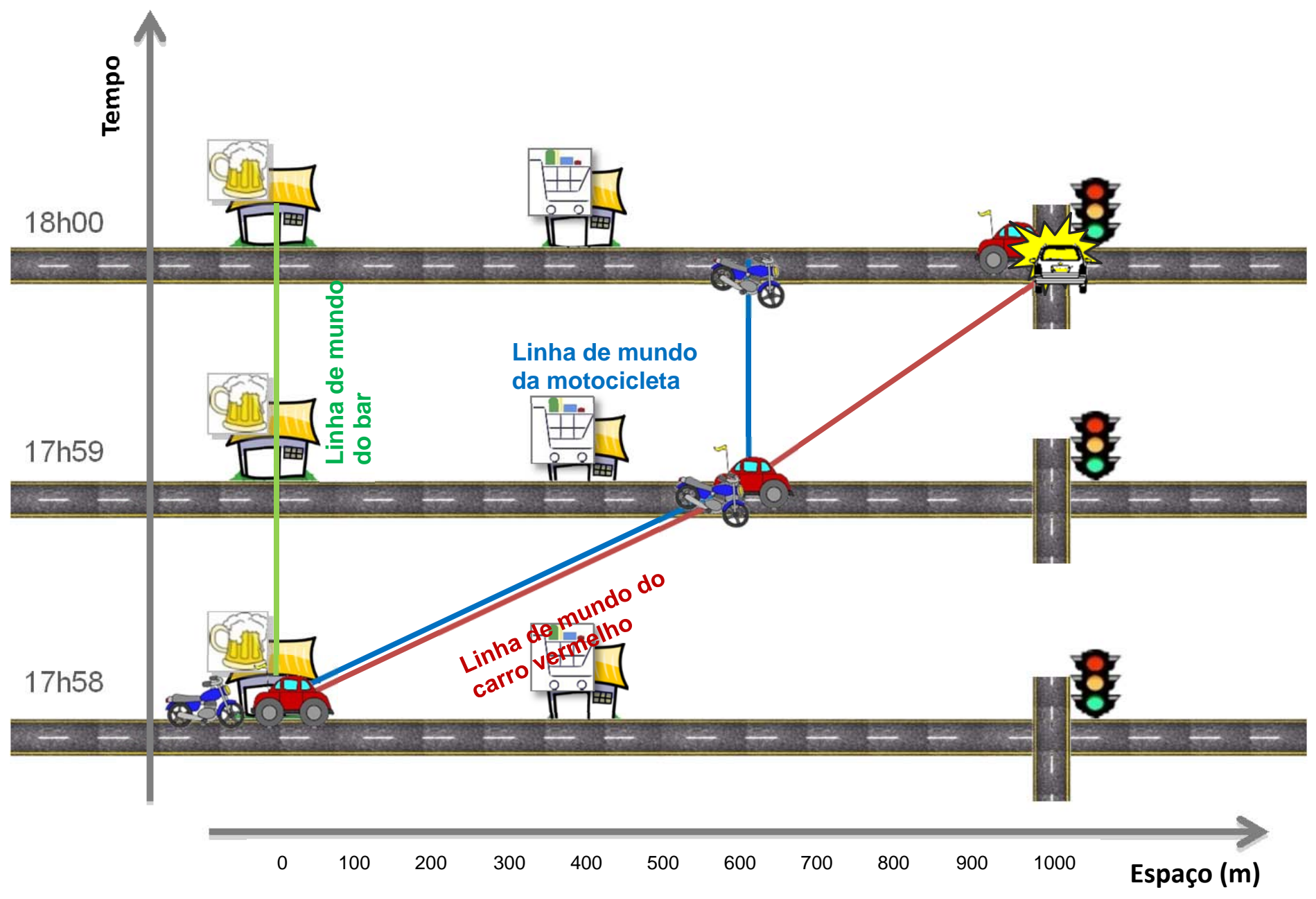




\section{Diagrama completo de eventos}

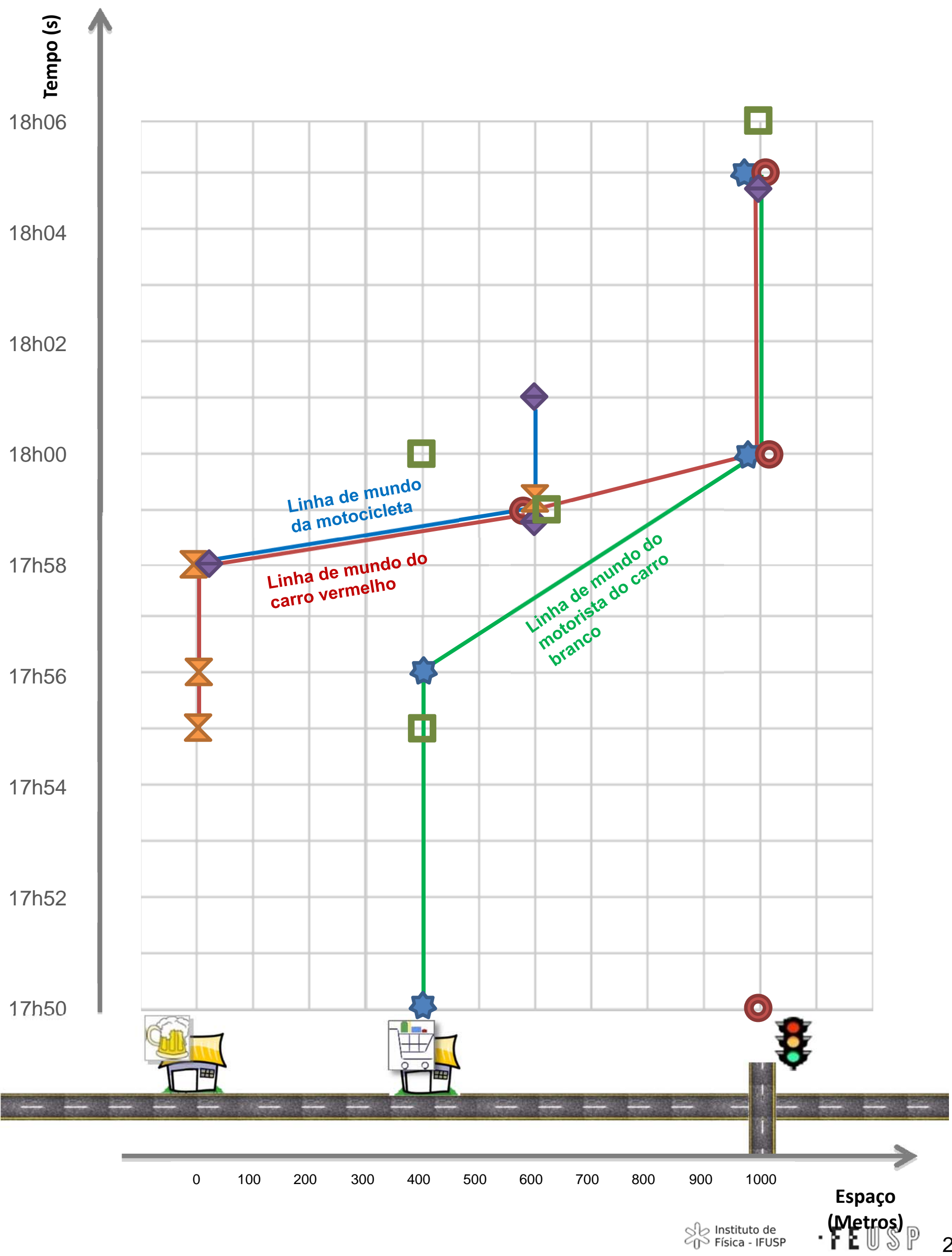




\section{Lista de eventos presentes nos depoimentos}

\section{Grupo 1}

\begin{tabular}{|c|c|c|}
\hline S & onde & quando \\
\hline Motorista carro branco entra no mercado & $400 \mathrm{~m}$ & $17 \mathrm{~h} 50$ \\
\hline Motorista do carro branco sai do mercado & $400 m$ & $17 \mathrm{~h} 56$ \\
\hline Batida & $1000 \mathrm{~m}$ & $18 \mathrm{h00}$ \\
\hline Chegada do resgate & $1000 m$ & $18 \mathrm{h05}$ \\
\hline
\end{tabular}

\section{Grupo 2}

\begin{tabular}{|c|c|c|c|}
\hline (0) & Mendigo & onde & quando \\
\hline \multicolumn{2}{|c|}{ Mendigo chega no semáforo } & $1000 m$ & $17 \mathrm{~h} 50$ \\
\hline \multicolumn{2}{|c|}{ Motorista do carro vermelho fecha motoboy } & $600 \mathrm{~m}$ & 17h59 \\
\hline \multicolumn{2}{|c|}{ Batida } & 1000m & $18 \mathrm{~h} 00$ \\
\hline & Chegada do resgate & $1000 \mathrm{~m}$ & $18 \mathrm{~h} 05$ \\
\hline
\end{tabular}

\section{Grupo 3}

\begin{tabular}{|c|c|c|}
\hline $\mathbf{V} \mid$ Velhinha & onde & quando \\
\hline Velhinha chega para esperar o neto & $400 \mathrm{~m}$ & $17 \mathrm{~h} 55$ \\
\hline Motorista do carro vermelho fecha motoboy & $600 \mathrm{~m}$ & $17 \mathrm{~h} 59$ \\
\hline Neto chega da escola & $400 \mathrm{~m}$ & $18 \mathrm{~h} 00$ \\
\hline Fotografia do neto & $1000 \mathrm{~m}$ & $18 \mathrm{~h} 06$ \\
\hline
\end{tabular}

\section{Grupo 4}

\begin{tabular}{|c|c|c|}
\hline O motoboy & onde & quando \\
\hline Motoboy encontra carro vermelho & $0 \mathrm{~m}$ & $17 \mathrm{~h} 58$ \\
\hline Motorista do carro vermelho fecha motoboy & $600 m$ & 17h59 \\
\hline Motoboy liga para o resgate & $600 m$ & 18h01 \\
\hline Resgate chega ao local & $1000 m$ & $18 \mathrm{~h} 05$ \\
\hline
\end{tabular}

\section{Grupo 5}

\begin{tabular}{|c|c|c|c|}
\hline$X$ & O Barman & onde & quando \\
\hline & Barman assiste programa de TV & $0 \mathrm{~m}$ & 17h55 \\
\hline & torista do carro vermelho entra do bar & Om & $17 \mathrm{~h} 56$ \\
\hline & otorista do carro vermelho sai do bar & $0 \mathrm{~m}$ & $17 \mathrm{~h} 58$ \\
\hline Mot & orista do carro vermelho fecha motoboy & $600 \mathrm{~m}$ & 17h59 \\
\hline
\end{tabular}

\section{Principais eventos}

\begin{tabular}{||l|c|c||}
\hline \multicolumn{1}{|c|}{ Eventos } & Onde (posição) & Quando (tempo) \\
\cline { 1 - 1 } Motorista do carro vermelho sai dirigindo do Bar do Zé & \multirow{2}{*}{$0 \mathrm{~m}$} & \multirow{2}{*}{$17 \mathrm{~h} 58$} \\
\cline { 1 - 1 } Motoboy encontra carro vermelho & $600 \mathrm{~m}$ & $17 \mathrm{~h} 59$ \\
\hline Motorista do carro vermelho fecha motoboy & $1000 \mathrm{~m}$ & $18 \mathrm{~h} 00$ \\
\hline Motorrista do carro vermelho bate no automóvel branco & $400 \mathrm{~m}$ & $17 \mathrm{~h} 50$ \\
\hline Motorista do carro branco entra no mercado & $400 \mathrm{~m}$ & $17 \mathrm{~h} 56$ \\
\hline Motorista do carro branco sai do mercado & & \\
\hline
\end{tabular}




\section{CENA DO PONTO DE VISTA DO FALECIDO BRÁS CUBAS:}

\section{MEMÓRIAS PÓSTUMAS}

Estava em casa tranquilo quando comecei a sentir uma dor no peito. Resolvi ir à farmácia para comprar meus placebos para o coração que haviam acabado. Durante o caminho de ida tudo ocorreu bem.

Porém, quando estava voltando, já com meus placebos, a dor começou a ficar muito forte e resolvi parar num bar para tomar meu medicamento. Entrei afobado no bar, mas como o ambiente era muito suspeito, pedi ao barman que me desse logo a água porque eu precisava tomar uma pílula. Tomei e saí apressado, pois queria chegar rápido em casa.

Entrei logo no carro, mas quando estava saindo, um motoqueiro ao meu lado me deu um grande susto, o que me fez perder o controle do carro. Depois de zigue-zaguear, retomei o controle do carro, mas já era tarde demais...

A dor no meu peito havia aumentado muito e minha vista havia ficado embaçada. Peguei o telefone para tentar avisar minha esposa e ao mesmo tempo procurava alguém na rua para pedir ajuda, mas como minha vista estava embaçada, por mais que abrisse os olhos, não via praticamente nada. Foi quando perdi a consciência e a última coisa que lembro foi de um barulho e o impacto da batida. 


\section{ATIVIDADE 8 - CAMINHONEIROS RELATIVÍSTICOS}

\section{OBJETIVO:}

No nosso dia a dia, assim como na dinâmica newtoniana, o tempo é entendido como algo absoluto que empurra todo o universo num fluxo constante de acontecimentos. Se imaginarmos um relógio no centro da cidade, não importa que estejamos em movimento dentro de um caminhão que passa ali próximo ou se estejamos sentados no banco da praça, o tic-tac-tic-tac do relógio sempre seria visto no mesmo ritmo. Contudo, vimos que o conhecimento científico avançou para uma nova compreensão sobre o significado de tempo. Se passarmos a olhar o mundo com mais cuidado, veremos que ele se comporta relativisticamente. Para aquele que está no referencial próprio do relógio, sentado na praça, o tic-tac-tic-tac do relógio é diferente do tic - tac - tic - tac visto por aquele que está passando ali perto em um caminhão ${ }^{1}$. De fato a ciência consegue provar com precisão estes fenômenos.

O curso está chegando a sua etapa final, na qual o objetivo é tratar o problema do paradoxo dos gêmeos que será completamente resolvido na próxima atividade através de uma resolução que se utiliza dos conceitos aprendidos nesta aula.

A discussão sobre as unidades de medidas utilizadas nesses casos é o primeiro objetivo a ser alcançado. Assim, o aluno deverá compreender a unidade ano-luz como distância, frações de "c" como unidade de velocidade (assim como 0,8c ou $80 \%$ da velocidade da luz). A ideia é criar um conhecimento de base para o segundo objetivo: a situação de aprendizagem do conceito de intervalo relativístico.

É interessante notar que o tempo absoluto presente no pensamento newtoniano pode ser considerado uma espécie de cola que conecta os eventos sempre da mesma forma. Dentro desta teoria, se um caminhoneiro diz que demorou 8h para entregar uma carga, o empregador que controla as entregas pode confirmar este tempo diretamente com seu próprio relógio de pulso e não haveria problema. Mas se as velocidades forem grandes, ou seja, se o caminhoneiro for relativístico, os tempos de entrega compreendido pelo caminhoneiro e pelo empregador poderiam ser bem diferentes. Quem estaria certo? Com a quebra do absolutismo newtoniano do tempo, como podemos determinar o intervalo entre os eventos "partida" e "chegada" do caminhão? Para resolver essas questões os estudos serão feitos sobre a situação fictícia dos "caminhoneiros relativísticos", na qual é necessário estabelecer o intervalo relativístico como padrão de medida de espaço-tempo para solucionar as complicações logísticas presentes no problema.

O intervalo relativístico é um valor que associa a duração temporal e a distância espacial entre dois eventos de modo que seu valor é sempre o mesmo não importando qual observador o calcule. Assim, o intervalo entre os dois eventos - "partida" e "chegada" - é o mesmo tanto pelas observações do caminhoneiro quanto pelas observações do empregador, mas em ambos os casos, o valor do intervalo relativístico será o mesmo não havendo ambiguidade.

\section{CONTEÚDO FÍsıCO:}

Intervalo Relativístico; Unidades de Espaço e Tempo; Representação Gráfica do Espaço-Tempo.

\section{RECURSOS:}

- Material instrucional para o professor (este)

- Material de apoio para o professor

- Folha de atividade sobre intervalo relativístico para aluno

- Folha de atividade extraclasse sobre eventos para o aluno

- Avaliação Local

\footnotetext{
${ }^{1}$ Claro que o caminhão necessitaria viajar em altíssima velocidade para que o fenômeno pudesse ser perceptível.
} 
MOMENTOS SUGERIDOS: APROXIMADAMENTE 1 AULA

\section{PROBLEMATIZAÇÃO E LEITURA DO TEXTO}

Com uma pequena apresentação do texto, em que o professor localiza o assunto envolvido, os alunos podem ser convidados à sua leitura. Isso pode ocorrer coletivamente, individualmente ou em grupos, de acordo com a preferência do professor.

É possível começar problematizando o papel que o tempo assume nos dias de hoje. Por exemplo, empresas de logísticas devem ser rápidas em transportar mercadorias de um depósito para uma fábrica e vice-versa. Em seguida, proponha aos alunos que imaginem como lidaríamos com o tempo no futuro da nossa sociedade.

\section{SUGESTÕES}

Após a leitura o professor pode tirar as dúvidas dos alunos sobre o texto. Como alguns alunos podem ter dificuldade com textos relativamente longos, o professor pode fazer oralmente um resumo da história para garantir que todos tenham uma compreensão mínima do assunto em discussão. Eventualmente, pode-se pedir que os próprios estudantes façam oralmente uma síntese da história relatada na atividade, dando destaque aos seus problemas.

Neste momento os alunos devem tentar responder às questões. Sempre é interessante deixálos trabalhar, individualmente ou em grupo, na busca das respostas. Dependendo do hábito da turma em resolver exercícios lógico-matemáticos, o professor pode se adiantar e resolver as questões coletivamente. No entanto, é importante sempre garantir tempo para que os alunos perguntem.

A primeira questão busca apenas sensibilizar o aluno para o problema do texto, que é reduzir tudo ao menor intervalo de tempo possível. Estando familiarizado com a ideia de diferenciação temporal, aparentemente a relatividade pode dar boas respostas para este problema prático. Contudo, o texto mostra que isso não é trivial.

A segunda questão busca indicar as dimensões envolvidas no problema e sua ordem de grandeza. Se anos-luz é o espaço percorrido pela luz em um ano, é estranho que se espere que alguma entrega seja feita em apenas alguns meses. Esta questão busca chamar a atenção do aluno para isso. Sugerimos que o professor faça uma explicação prévia do significado das unidades.

A terceira questão busca tratar em termos formais a discussão iniciada na questão anterior. $\mathrm{Na}$ parte $\mathrm{A}$, o aluno deve perceber que para descobrir o valor de um ano-luz em quilômetros é necessário multiplicar o tempo de um ano (que deverá ser transformado em segundos, ficando $31.536 .000 \mathrm{~s}$ ) pela velocidade da luz em quilômetros por segundo $(300.000 \mathrm{~km} / \mathrm{s})$. Assim, pode-se chegar ao valor de $9,46 \times 10^{12} \mathrm{~km}$, algo extremamente alto para nossos padrões cotidianos.

Na segunda parte da questão é necessário que fique claro que quando trabalhamos com as unidades ano (tempo) e ano-luz (espaço), que são mais convenientes quando estamos lidando com grandes dimensões 


\section{SUGESTÕES}

m Nesse terceiro momento, o intervalo relativístico pode ser apresentado algebricamente. Sugerimos que o professor apresente a equação e seu significado indicando que o tempo e o espaço, entendidos independentemente, são relativos a quem observa. Mas relacionando entre estas duas grandezas corretamente, é possível gerar uma medida espaço-temporal que tem sempre o mesmo valor independentemente do referencial adotado (para maiores informações, veja o material de apoio) .

$$
I=\sqrt{\left(c \Delta t_{A}\right)^{2}-\left(\Delta x_{A}\right)^{2}}=\sqrt{\left(c \Delta t_{B}\right)^{2}-\left(\Delta x_{B}\right)^{2}}
$$

O professor pode explicar a aplicação do intervalo relativístico resolvendo a questão 4.

\section{SUGESTÕES}

Para finalizar, deixe claro que o referencial adotado para montar o gráfico está fixo na Terra e não no viajante. Assim, os eventos a serem colocados no gráfico são informações obtidas por meio do referencial do empresário. Peça aos alunos que localizem os eventos no gráfico e discuta rapidamente as unidades dos eixos coordenados no espaço-tempo.

Finalmente sugerimos ao professor que entregue a atividade para casa.

\begin{tabular}{|c|c|}
\hline مص & AVALIAÇÃO LOCAL \\
\hline है & $\begin{array}{l}\text { Não se esqueça de aplicar a avaliação local nos últimos } 5 \text { minutos. Sugerimos não deixar como } \\
\text { tarefa para casa. }\end{array}$ \\
\hline
\end{tabular}




\section{O Problema dos Caminhoneiros Relativísticos do século XXII.}

\section{Leia a história abaixo e discuta as questões em seguida:}

Cada vez mais todos nós vivemos com pressa. Todo mundo corre para todo lado, sempre "lutando contra o tempo". Em nosso mundo, tudo deve ser feito no menor intervalo de tempo possível.

Nos dias de hoje, em 2180, quem mais sofre com isso são os caminhoneiros. Como eles são responsáveis por fazer as entregas de tudo que precisamos, acabam literalmente vivendo na correria.

O problema vem se agravando. As pessoas começaram a habitar outros planetas e as entregas passaram a ser interplanetárias. Mesmo vivendo em planetas a "anos-luz" da Terra, todos ainda querem que produtos "importados" cheguem após alguns meses!

Um engenheiro e empresário muito conhecedor de física decidiu resolver este problema. Ele desenvolveu os "caminhoneiros relativísticos", que andam próximo à velocidade da luz. De acordo com ele, além da vantagem de viajarem próximo da mais alta velocidade possível, o fato de o tempo passar mais lentamente nestes casos faria com que os produtos perecíveis fossem entregues antes de estragarem, deixando seus clientes satisfeitos. Nesta empresa, caminhoneiro bom é o que faz entrega em pouco tempo. Contudo, o problema estava só começando...

Logo na primeira viagem começou a confusão. O caminhoneiro jura que fez sua entrega em exatos 7 meses e 6 dias. Já o responsável da empresa, que gerencia e controla as entregas, afirma que ele demorou 9 meses e 18 dias estourando o prazo limite da entrega que era de 8 meses, e por isso não fará seu pagamento. O caso foi parar na justiça, no tribunal de Haia!

Quando o caso chegou à corte, o juiz se negou a fazer seu julgamento. Ele, também muito conhecedor de física, afirmou não haver solução. Em suas palavras: "De acordo com a Teoria da Relatividade, o tempo transcorrido entre dois eventos varia de acordo com o estado de movimento relativo. Desta forma, o tempo entre o caminhão sair do centro de cargas e fazer sua entrega nunca será o mesmo para o caminhoneiro, que faz a viagem, e para o responsável, que ficou na empresa".

Perante a situação todos perguntaram: "Não existe alguma maneira de entrarmos em acordo? Senão a empresa precisará fechar e todos perderão o emprego!". Neste momento, Sheldon se levanta e diz: "A solução é muito simples, basta vocês combinarem o pagamento por meio do intervalo relativístico (I) que deve ser feita a entrega". Então todos o observaram com expressão de espanto e disseram: "Não entendi!" Logo, ele continuou:

"Embora um intervalo de tempo das viagens seja diferente para o caminhoneiro que viaja e para o responsável da empresa que fica na Terra, existe uma grandeza absoluta que poderia ser usada para resolver o problema justamente porque ela é independentemente do referencial e igual pra todo mundo.

$$
\begin{gathered}
I=\sqrt{\left(c \Delta t_{A}\right)^{2}-\left(\Delta x_{A}\right)^{2}} \text { a partir da perspectiva do empresário . } \\
I=\sqrt{\left(c \Delta t_{B}\right)^{2}-\left(\Delta x_{B}\right)^{2}} \text { a partir da perspectiva do caminhoneiro. }
\end{gathered}
$$

Com base nas ideias de Sheldon, o tribunal de Haia promoveu uma revolução na entrega de mercadorias. Os jornais reportaram por semanas que todos passaram a compreender como nem tudo é relativo. 


\section{Problemas:}

1 - Logo no início da história é dito que as pessoas "lutam contra o tempo". O que isso significa de acordo com a Teoria da Relatividade?

2 - O texto afirma que "mesmo vivendo em planetas a "anos-luz" da Terra, todos ainda querem que produtos "importados" cheguem após alguns meses". Por que esta é uma afirmação contraditória? Justifique pensado sobre o significado da unidade "anos-luz".

3 - Um ano-luz é a distância percorrida pela luz no período de um ano. Isto é, depois de transcorrido o Tempo de 1 ano, a luz percorreu a Distância de 1 ano-luz.

a) Como podemos descobrir esta distância em quilômetros?

4 - Considere o caso de um caminhoneiro que, de acordo com o empresário que ficou na Terra, viajou durante 1 ano e percorreu a distância de 0,8 anos-luz até uma filial.

a) Qual foi seu intervalo relativístico entre os eventos "partir" e "chegar" nesta viagem?

b) Quanto tempo passou para o caminhoneiro?

c) Represente os eventos partida e chegada no gráfico abaixo e desenhe o caminho no espaço-tempo que o caminhoneiro percorreu.

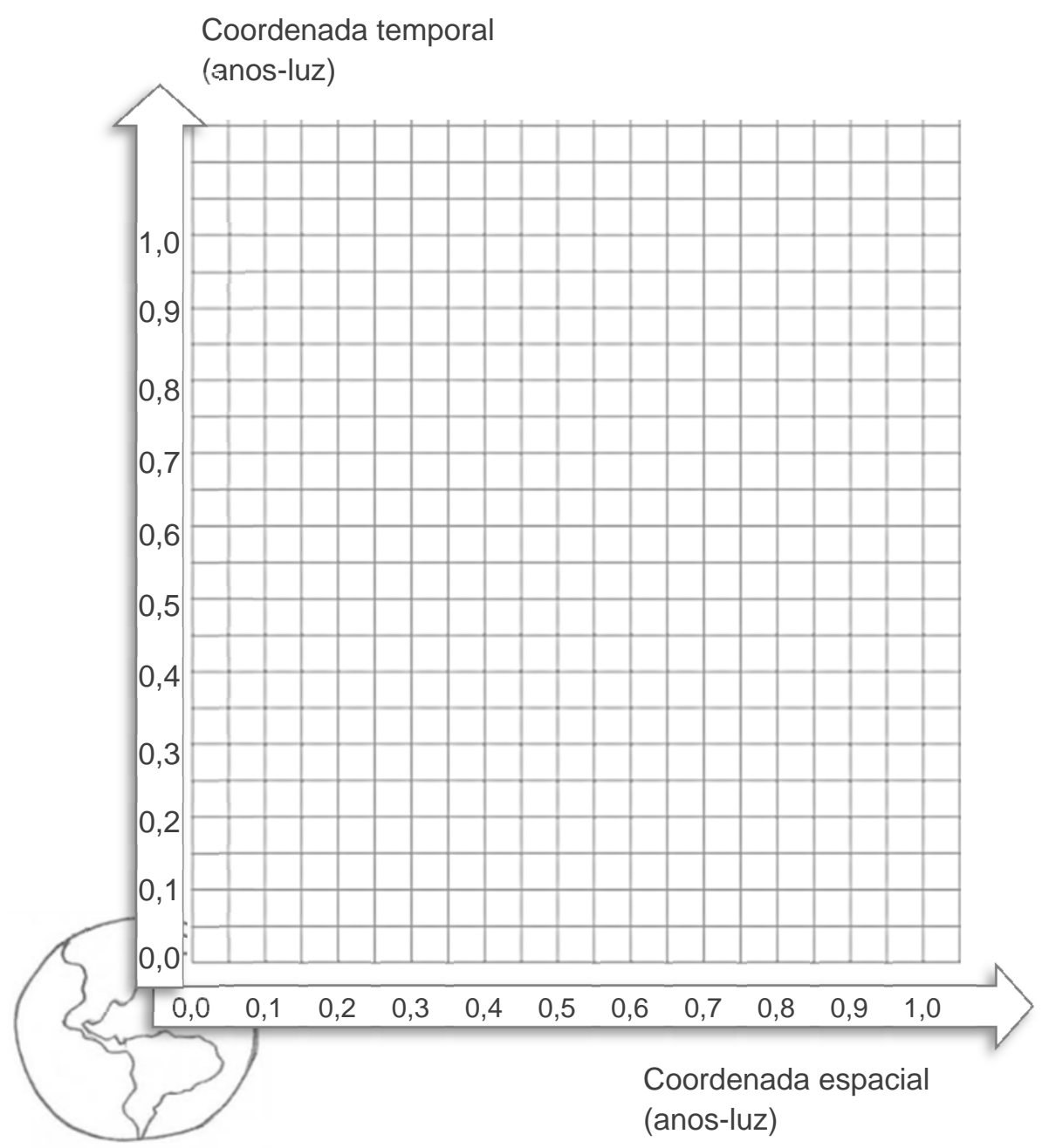

O gráfico ao lado está no referencial da Terra.

Use

$x$ : coordenada espacial em anos-luz

$t$ : coordenada temporal em anos

ct: coordenada temporal relativística em anos-luz

v: velocidade em múltiplos da velocidade da luz. ("luz") 


\section{Atividade 8 - Caminhoneiros Relativísticos Material de apoio ao professor}

O intervalo relativístico mede a separação espaço-temporal entre dois eventos. Para compreender melhor esse conceito, é necessário antes compreender o que é evento. Neste texto procuramos apresentar a linha de raciocínio que sugerimos para tal abordagem.

\section{EM QUE LUGAR E EM QUE MOMENTO?}

Ao longo das nossas vidas vivenciamos e observamos vários eventos, os quais nos referimos dizendo sempre em que local e em que momento eles aconteceram: o nosso primeiro beijo foi no cinema no dia 2 de outubro, eu peguei o ônibus $7 \mathrm{~h} 45$ no centro da cidade. A representação dos eventos é feita apenas com suas coordenadas de tempo (sabendo a hora em que ocorreu) e a posição (sabendo onde o evento ocorreu).

\section{O evento é a representação física de um acontecimento qualquer no universo.}

Evento: $1^{\circ}$ beijo

Coordenada: (cinema; 02/10)

Evento: subiu no ônibus

Coordenada: (centro; 7h45)

(notação informal)

Às vezes um evento é confundido com uma sequência de eventos no nosso dia a dia. Como exemplo de um único evento, podemos imaginar um pingo no "i" quando estamos escrevendo, pois ele acontece em um momento e em um ponto no espaço. Por outro lado, a escrita de um texto é um conjunto imenso de eventos, uma vez que o encontro do papel com a caneta acontece em diversas posições em diversos momentos diferentes.

Objetos como uma caneca criam eventos de forma contínua no universo. Assim, quando vemos uma caneca sobre uma mesa estamos presenciando uma linha de eventos, pois apesar da caneca permanecer parada na mesma posição, ela ocupa diferentes posições no tempo. Da mesma forma, um carro ou um foguete passando pela rua também geram linhas contínua de eventos, mas que agora se diferenciam não só no tempo como no espaço.

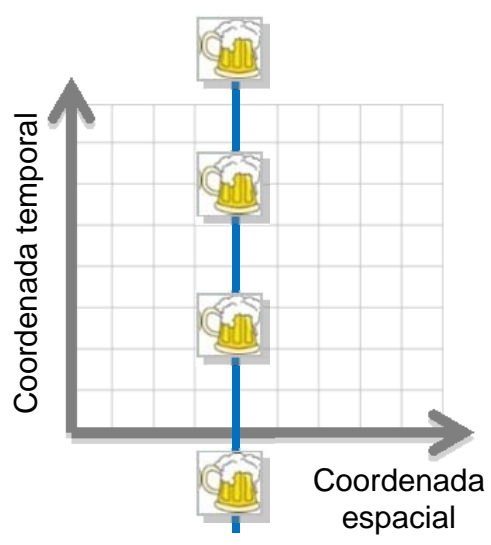

Linha de mundo da caneca parada sobre a mesa

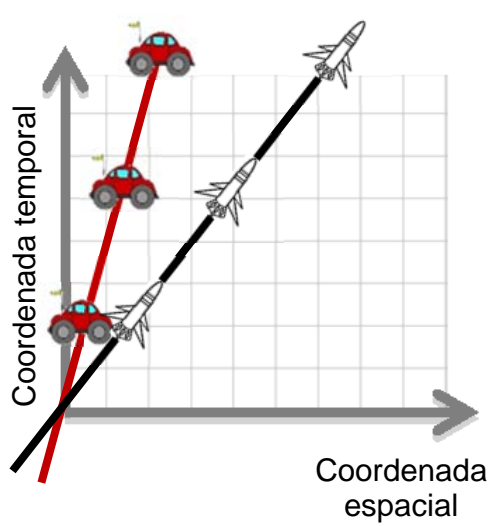

Linha de mundo do carro e do foguete passando pela rua com velocidade

O nome linha de mundo é dado a toda sequência de eventos produzida pela existência de um objeto em movimento ou parado no universo. É uma espécie de trajetória que é feita não só no espaço, como no tempo. 
Como exemplo, iremos abordar a resolução da questão 4 presente no material do aluno.

É importante observar que estamos num momento da sequência didática intermediário entre as representações clássicas e representações relativísticas. A linha de mundo repousa sobre um gráfico espaçotemporal (normalmente quadridimensional, com 3 eixos espaciais e 1 temporal) o qual exige uma interpretação diferenciada dos tradicionais gráficos utilizados em física clássica.

Devido à união do espaço com o tempo, uma grande diferença surge na unidade do eixo temporal. O eixo possa a ter unidade de espaço (anos-luz nos casos estudados neste curso) e o tempo aparece sempre multiplicado pela velocidade da luz c no gráfico.

Assim a coordenada temporal $t=1$ ano é representada no diagrama como $c t=1$ ano_luz.

O foguete viaja 0,8 anos-luz durante 1 ano possui, então, como eventos principais:

Evento 1: saída do caminhão

Coordenadas: (0 anos-luz ; 0 anos-luz)

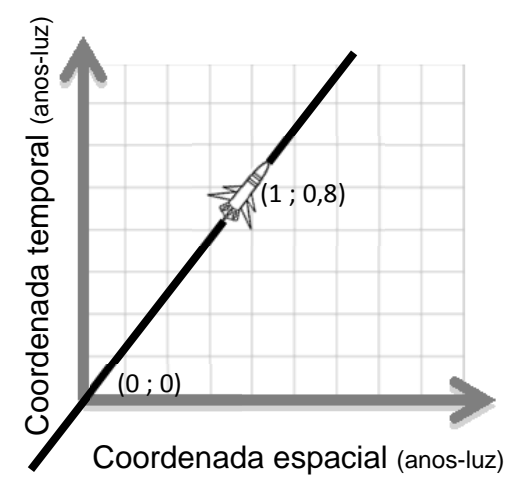

Evento 2: chegada do caminhão

Coordenadas: (1 ano-luz ; 0,8 ano-luz)

Observe que o gráfico é desenhado no referencial de quem está na Terra.

\section{INTERVALO RELATIVÍSTICO}

O intervalo relativístico ${ }^{1}$ é uma espécie "distância" entre eventos no espaço-tempo.

De fato, a equação que o define guarda função muito semelhante à do teorema de Pitágoras, entretanto grandes diferenças também surgem: não são consideradas somente dimensões espaciais na equação, a duração entre os dois eventos influencia no "tamanho" do intervalo. Essa peculiaridade faz com que uma "distância" espaço-temporal seja bem diferente de uma distância clássica.

A mais importante característica do intervalo relativístico é sua invariância por mudança de referencial. Ou seja, da mesma forma que o valor da velocidade da luz, o valor do intervalo é sempre o mesmo independentemente do referencial a partir do qual é calculado. Algebricamente, ele assume a seguinte forma:

$$
\boldsymbol{I}=\sqrt{\left(\boldsymbol{c} \Delta \boldsymbol{t}_{A}\right)^{2}-\left(\Delta x_{A}\right)^{2}}=\sqrt{\left(c \Delta \boldsymbol{t}_{B}\right)^{2}-\left(\Delta x_{B}\right)^{2}}=\sqrt{\left(c \Delta t_{C}\right)^{2}-\left(\Delta x_{C}\right)^{2}} \ldots
$$

- O observador A compreende que a duração entre os dois eventos é $\Delta t_{A}$ e a distância entre os eventos é $\Delta x_{A}$

o O observador B compreende que a duração entre os dois eventos é $\Delta t_{B}$ e a distância entre os eventos é $\Delta x_{B}$

- O observador C compreende que a duração entre os dois eventos é $\Delta t_{C}$ e a distância entre os eventos é $\Delta x_{C}$

- Todos chegam ao mesmo intervalo relativístico, independentemente de suas observações.

\footnotetext{
${ }^{1}$ Conhecido também por distância quadridimensional ou 4-distance.
} 
O teorema de Pitágoras permite determinar a distância entre dois pontos com a soma do quadrado dos catetos. O intervalo relativístico, por sua vez, subtrai os quadrados revelando uma concepção espacial distorcida e muito diferente.

Algo interessante é que quando se calcula o intervalo entre eventos em uma linha de mundo, ele já carrega em seu cerne o limite para a velocidade do objeto que a cria. Um exercício interessante para o professor talvez seja imaginar uma situação onde dois eventos acontecem a uma distância $\Delta x$ e estão separados temporalmente por uma duração $\Delta \boldsymbol{t}$. A equação do intervalo nos diz que se a distância $\Delta \boldsymbol{x}$ for maior do que a distância percorrida pela luz durante $\Delta t$, então não há uma solução real para a equação. Ou seja, nenhum objeto pode

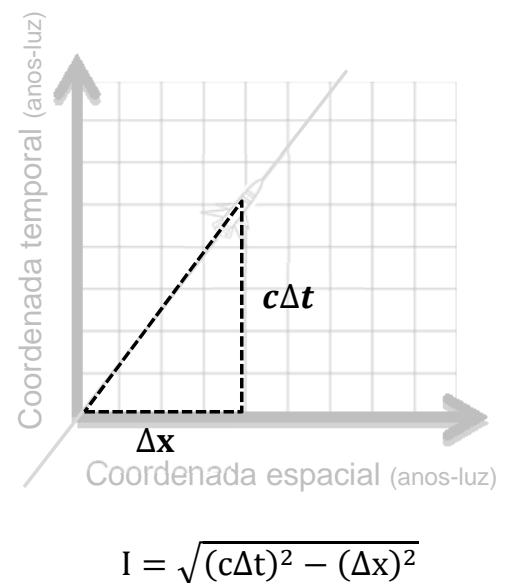
criar tais eventos, pois tal objeto necessitaria estar a uma velocidade superior à da luz para que isso fosse possível. (c $\Delta \mathrm{t}$ é a maior distância possível de ser percorrida no intervalo de tempo $\Delta \mathrm{t})$

$$
\begin{gathered}
\mathrm{I}=\sqrt{(\mathrm{c} \Delta \mathrm{t})^{2}-(\Delta \mathrm{x})^{2}} \\
\text { se } \Delta \mathrm{x}>\mathrm{c} \Delta \mathrm{t} \Rightarrow(\mathrm{c} \Delta \mathrm{t})^{2}-(\Delta \mathrm{x})^{2}<1 \\
\therefore \nexists \mathrm{I} \in \mathbb{R}
\end{gathered}
$$

Assim, os dois eventos separados por $\Delta \mathrm{x}$ e por $\Delta \mathrm{t}$ estão tão separados que não podem possuir relação de causalidade.

Ainda relacionada ao problema 4, há uma questão técnica sobre análise dimensional que necessita ser esclarecida. O cálculo do intervalo relativístico para o caso dos caminhoneiros pode ser mais facilmente feito se as unidades de tempo forem dadas em anos e as de distância em anos-luz. Nestas condições, as velocidades tornam-se múltiplas da velocidade da luz. Assim se o nosso foguete viajou $\Delta x_{A}=0,8$ anos_luz em $\Delta t_{A}=1$ ano, significa que sua velocidade média era $v=0,8 c$.

Mas qual seria a unidade de medida? É claro que se desejarmos saber a velocidade no sistema internacional, basta conhecer a velocidade da luz em $\mathrm{m} / \mathrm{s}$ e multiplica-la. Mas, nesse caso, a unidade atrapalhará o desenvolvimento dos cálculos. Vale mais a pena utilizar uma unidade informal, mas muito útil dizendo que a velocidade do foguete é de " 0,8 da velocidade da luz" ou simplesmente " 0,8 luz".

$$
v=\frac{0,8 \text { anos_luz }}{1 \text { ano }} \text { ou simplesmente } v=0,8 \mathrm{luz}
$$

Para saber quanto tempo passou na perspectiva do caminhoneiro, basta sabermos as informações a partir do referencial do empregador, descobrirmos o intervalo relativístico e recalculá-lo no referencial do caminhoneiro.

Para o empregador na Terra, a viajem feita pelo caminhoneiro possui as seguintes características:

$$
\begin{aligned}
& \Delta t_{A}=1 \text { ano } \\
& \Delta x_{A}=0,8 \text { anos. luz }
\end{aligned}
$$

Assim o intervalo relativístico pode ser calculado da seguinte forma.

$$
\begin{aligned}
& I^{2}=\left(c \Delta t_{A}\right)^{2}-\left(\Delta x_{A}\right)^{2} \\
& I^{2}=(1 \text { luz. } 1 \text { anos })^{2}-(0,8 \text { anos. luz })^{2} \\
& I^{2}=(1-0,64) \cdot(\text { anos. luz })^{2} \\
& I^{2}=0,36 \cdot(\text { anos. luz })^{2} \\
& I=\sqrt{0,36} \text { anos. luz } \\
& I=0,6 \text { anos. luz }
\end{aligned}
$$


O entendimento das soluções anteriores é importante para que no momento da resolução o c presente na equação desapareça das contas. O professor pode desenvolver a compreensão das passagens junto aos alunos se julgar necessário.

Uma vez encontrado o intervalo relativístico, nós sabemos que o seu valor é o mesmo para qualquer observador que tenha visto os dois eventos (partida e chegada do caminhoneiro). É importante notar que não sabemos quanto tempo se passou entre os eventos na perspectiva do caminhoneiro, entretanto, sabemos que o evento de partida e chegada ocorre no mesmo lugar para ele (a porta do caminhão, por exemplo).

Assim: $\quad I^{2}=\left(c \Delta t_{A}\right)^{2}-\left(\Delta x_{A}\right)^{2}=(0,6 \text { anos. luz })^{2}=\left(c \Delta t_{B}\right)^{2}-\left(\Delta x_{B}\right)^{2}$

Evento 1: saída do caminhão

Coordenadas: (0 anos-luz ; 0 anos-luz)

Evento 2: chegada do caminhão

Coordenadas: (? ; 0 anos-luz) no referencial do caminhoneiro, tanto a partida quanto a chegada ocorrem no mesmo lugar.

$$
\begin{gathered}
\Delta t_{B}=? \\
\Delta x_{B}=0 \text { anos. luz } \\
(0,6 \text { anos. luz })^{2}=\left(1 \text { luz. } \Delta t_{B}\right)^{2}-\left(\Delta x_{B}\right)^{2} \\
(0,6 \text { anos. luz })^{2}=\left(1 \text { luz. } \Delta t_{B}\right)^{2} \\
0,6 \text { anos }=\Delta t_{B} \neq \Delta t_{A}=0,8 \text { anos }
\end{gathered}
$$

O professor pode fazer uma comparação direta para mostrar como a duração entre dois eventos é diferente para os dois referenciais. 
Nome:

Prof.

série:

data:

\section{Para casa}

\section{Leia a história abaixo e responda as questões}

$\underline{10}$ ato

Foi então que numa terça-feira de manhã, a grande viagem aconteceria.

O protótipo estava pronto para o teste. Adam prometeu ao seu irmão Sheldon que estaria esperando-o naquele mesmo local em 20 anos, quando Sheldon voltasse. Ele sabia que o foguete viajaria a uma velocidade incrível por longos 10 anos para só então, voltar com a mesma velocidade.

$\underline{20}$ ato

E assim aconteceu. Adam observou da Terra todos os momentos da viagem de Sheldon. Sua saída, sua viagem de ida, sua parada, sua viagem de volta e finalmente a tão esperada chegada que aconteceu exatamente como o projeto previa, 20 anos depois. O tão esperado reencontro dos irmãos finalmente aconteceu e gerou um enorme espanto para eles e todos os presentes.

3o ato

Isso porque a emoção não era apenas por causa da saudade. Depois da viajem, Sheldon havia envelhecido, mas muito menos que Adam. Esse fato revelou uma estranha característica da natureza até então explorada apenas nos aceleradores de partículas presentes em laboratórios científicos: a diferenciação temporal.

Adam e Sheldon ficaram famosos e chegaram a escrever livros sobre o caso. Tudo porque eles ainda eram gêmeos nascidos na mesma data, mas que não viveram a mesma quantidade de anos graças a uma viagem muito rápida, mas mesmo assim uma simples viagem.

Leia a história acima e crie uma versão em quadrinhos dos principais eventos presentes no $2^{\circ}$ ato.

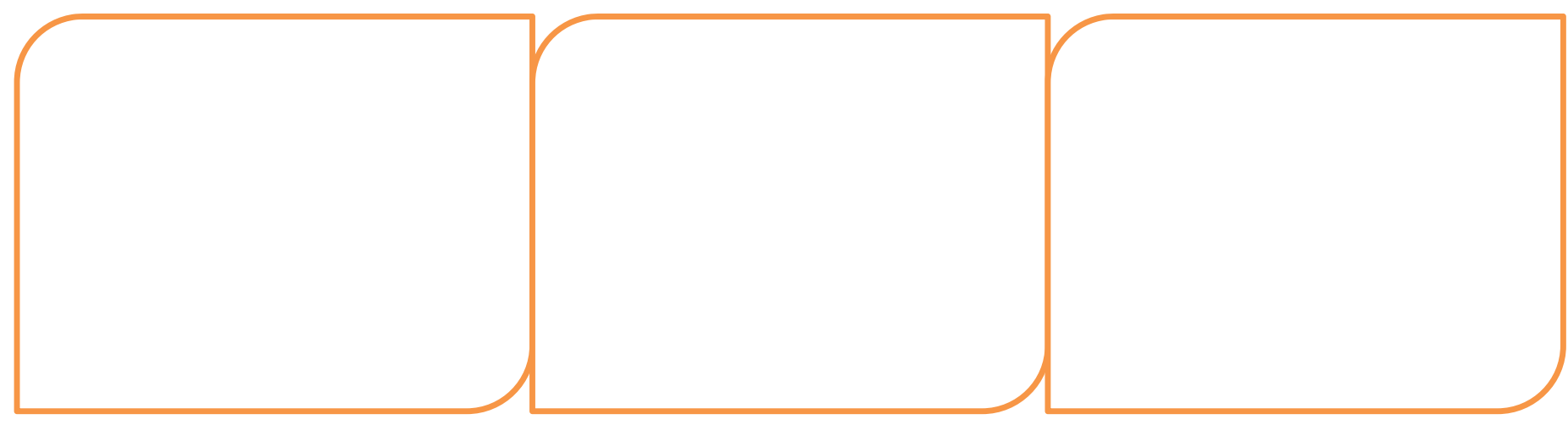




\section{ATIVIDADE 9 - VIAGEM NO ESPAÇO- TEMPO}

\section{OBJETIVO:}

Esta é a última atividade do curso e seu o objetivo é tratar e desvendar a falsidade do paradoxo dos gêmeos. A solução envolverá uma resolução geométrica num diagrama espaço-tempo referenciado na Terra. Sugerimos fortemente que sejam resgatados os elementos presentes em atividades anteriores durante a solução do paradoxo para que a totalidade do curso possa ser compreendida e validada pelos alunos. Esta atividade é de conclusão e deve ser aberta para que os alunos se expressem.

É objetivo desta atividade que o aluno compreenda que o paradoxo dos gêmeos é uma construção baseada numa simetria que não existe:

$>$ Se nos colocássemos no referencial de Adam, na Terra, veríamos Sheldon ir embora e voltar. Logo Sheldon envelheceria mais lentamente.

Se nos colocássemos no referencial de Sheldon, na nave, veríamos Adam ir embora e voltar. Logo Adam e todo o planeta Terra envelheceria mais lentamente.

Sendo a situação aparentemente simétrica quando trocamos de referenciais, como poderiam ambos envelhecer diferentemente? Quem envelhece menos aquele que viaja ou o que fica na Terra?

A aparente simetria vem uma omissão importante na situação proposta: normalmente é omitido que o gêmeo viajante muda de referencial entre os eventos de partida e chegada. Isso faz toda a diferença nas descrições feitas pelo irmão que fica na Terra e pelo viajante, uma vez que o primeiro experimenta apenas um referencial entre os eventos de partida e chegada, já o irmão que viaja experimenta um referencial durante a ida e um segundo referencial durante a volta para a Terra.

É importante compreender que o diagrama de espaço-tempo que tratamos aqui só pode ser construído se estiver "fixado" num referencial inercial. A construção de outro diagrama a partir do referencial do viajante exigiria habilidades matemáticas que não são tratadas durante o curso e por esse motivo não recomendamos qualquer tentativa em abordar esse aspecto.

É necessário também trabalhar a aula de modo a fazer com que os eixos do diagrama sejam bem compreendidos pelos alunos. O diagrama é construído por dois eixos coordenados: um deles é o bem conhecido eixo espacial na direção horizontal e o outro está totalmente relacionado com o tempo, mas não é o tempo propriamente dito. Certamente os alunos estranharão o fato de que a coordenada temporal presente no diagrama de espaço-tempo possui unidade de distância (anos-luz), mas isso é resultado da nova visão de mundo promovida pela relatividade einsteiniana. Nela os conceitos de espaço e tempo newtoniano são misturados permitindo-nos compreender o mundo não com 3 dimensões espaciais e 1 dimensão temporal, mas sim numa única estrutura quadridimensional (com 4 dimensões). Tais dimensões não se constituem nem coordenadas espaciais e nem temporais no sentido newtoniano, mas sim coordenadas espaço-temporais organizadas a partir da teoria da relatividade einsteiniana. Deste modo, é interessante indicar ao aluno que quando falamos em coordenada temporal no espaço quadridimensional, estamos falando sobre ct (em anosluz) e não simplesmente em tempo (t).

\section{CONTEÚdO FÍsıCO:}

Intervalo Relativístico; deslocamento no Espaço-Tempo; cálculo de intervalos de tempo relativísticos. 


\section{RECURSOS:}

- Material instrucional para o professor (este)

- Folha de atividade para aluno

- Avaliação Local

\section{MOMENTOS SUGERIDOS: ENTRE 1 AULA E 1,5 AULAS}

\section{SUGESTÕES}

A aula pode ser iniciada sob a motivação de que nesta última atividade será desvendado o fato do gêmeo astronauta envelhecer mais lentamente do que seu irmão que fica na Terra. Talvez valha a pena re-problematizar este fato que foi apresentado na primeira atividade. Em seguida, faça uma pequena apresentação do texto presente no início da folha de atividades, de modo a assegurar que os alunos entendam o que deve ser feito para a realização das tarefas. Sugerimos que os alunos leiam a primeira parte do texto com auxílio do professor, antes de iniciarem as tarefas.

\section{SUGESTÕES}

Após a leitura desta parte do texto o professor pode tirar eventuais dúvidas. Peça que realizem as tarefas de 1 a 3 . Antes de continuarem, certifique-se que todos os alunos foram capazes de realizálas, inclusive a representação dos deslocamentos dos dois gêmeos no digrama espaço-tempo como na atividade anterior. Deixe claro para todos que não se trata de um gráfico como aqueles feitos nas aulas de cinemáticas, mas de uma versão modificada. Peça que realizem as duas outras tarefas. Nelas há cálculos a serem feitos usando o Intervalo relativístico apresentado na atividade anterior. Vale a pena uma menção a ele de modo que eventuais dúvidas possam ser manifestadas.

\section{SUGESTÕES}

O momento final deve ser usado para interpretar os resultados obtidos e avaliar se os alunos foram capazes de perceber que para o Gêmeo que viajou na nave espacial o tempo passou mais devagar. Destaque que o irmão que ficou na Terra tem um deslocamento do tipo tempo: embora tenha se deslocado no espaço-tempo, ele não se moveu no espaço. Mostre que no caso do Gêmeo viajante, ele se move no espaço e o tempo. Faça uma discussão aberta com os alunos de modo que eles possam aproveitar para externar duvidas, ou interpretações pessoais sobre as atividades em geral. Dê um grande destaque para a falsidade do paradoxo. Mostre que na verdade, os movimentos dos dois Gêmeos não são simétricos um em relação ao outro. Isto pode ser visto no tipo de deslocamento que cada um deles fez no espaço-tempo.

\begin{tabular}{|c|c|}
\hline & AVALIAÇÃO LOCAL \\
\hline 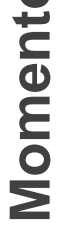 & $\begin{array}{l}\text { Não se esqueça de aplicar a avaliação local nos últimos } 5 \text { minutos. Sugerimos não } \\
\text { deixar como tarefa para casa. }\end{array}$ \\
\hline
\end{tabular}


Nome:

Prof.

série:

data:

\section{Viagens no espaço-tempo}

\section{Leia o texto abaixo e em seguida realize as tarefas:}

As atividades anteriores deixaram claro que dois irmãos gêmeos podem ter idades diferentes. Isto acontece, pois o tempo passa diferentemente quando tomamos referencias inerciais diferentes para medir o tempo. Neste caso, a própria noção de movimento se modifica de acordo com o referencial adotado, porque um corpo em movimento num referencial pode estar parado em relação a outro. No caso de existir uma velocidade relativa entre dois referenciais, a duração temporal entre dois acontecimentos é diferente para cada um deles. Por exemplo, se um despertador disparar um alarme, as duas pessoas em referenciais inerciais diferentes podem discordar sobre a duração do alarme desde quando começou a despertar até parar.

Nesta atividade iremos tentar esclarecer que o caso das idades dos gêmeos apresentado no início deste módulo é na verdade um falso paradoxo. Para isto usaremos todo o conhecimento adquirido da primeira atividade até agora.

Atenção, precisamos:

1. representar o movimento de cada um dos Gêmeos no diagrama;

2. lembrar que o intervalo relativístico é sempre o mesmo para qualquer referencial.

$$
\boldsymbol{I}=\sqrt{\left(c \Delta t_{A}\right)^{2}-\left(\Delta x_{A}\right)^{2}}=\sqrt{\left(c \Delta t_{S}\right)^{2}-\left(\Delta x_{S}\right)^{2}} \ldots
$$

3. tudo acontece descrito pelo referencial do gêmeo que ficou parado na Terra;

\section{Tarefas:}

1. Considere dois irmãos gêmeos, Adam e Sheldon. Um dos irmãos, Sheldon, entra em uma nave espacial que viaja a velocidade próxima da luz, enquanto Adam fica na Terra. A velocidade da nave foi determinada por Adam quando viu a nave passar a $80 \%$ da velocidade da luz $(0,8 \mathrm{c})$ em direção ao espaço. De acordo com ele, qual será a distância percorrida por Sheldon após 5 anos de viagem? E após 10 anos?

(importante: para facilitar as contas, que tal deixar as grandezas em função da velocidade da luz?)
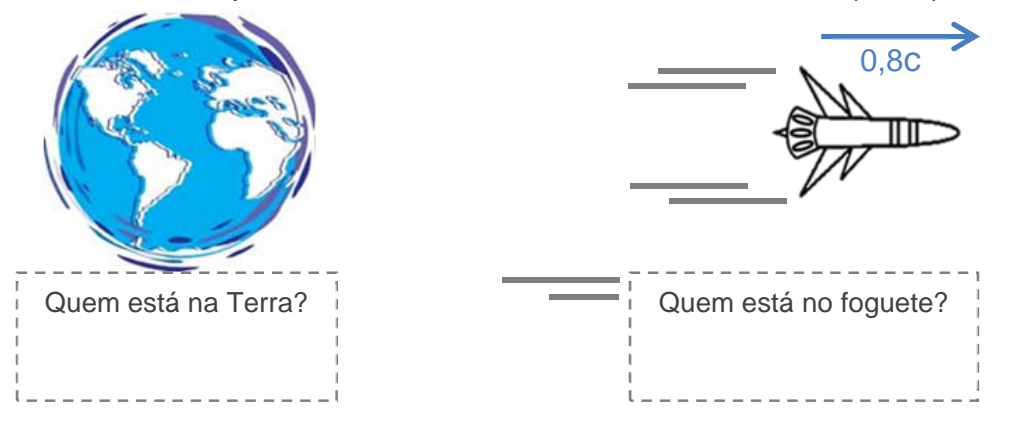

2. Adam sabe que o foguete viajará a uma velocidade incrível por longos 10 anos para só então, voltar com a mesma velocidade. Para Adam, quanto tempo a nave viajará? E qual será a distância total percorrida? 
3. Represente no diagrama abaixo os 3 eventos mais importantes na viagem de ida-e-volta de Sheldon como "vistos" por Adam na Terra.

(importante, o eixo das abscissas corresponde à direção do movimento da viagem e o das ordenadas ao tempo multiplicado pela velocidade da luz (c.t)).

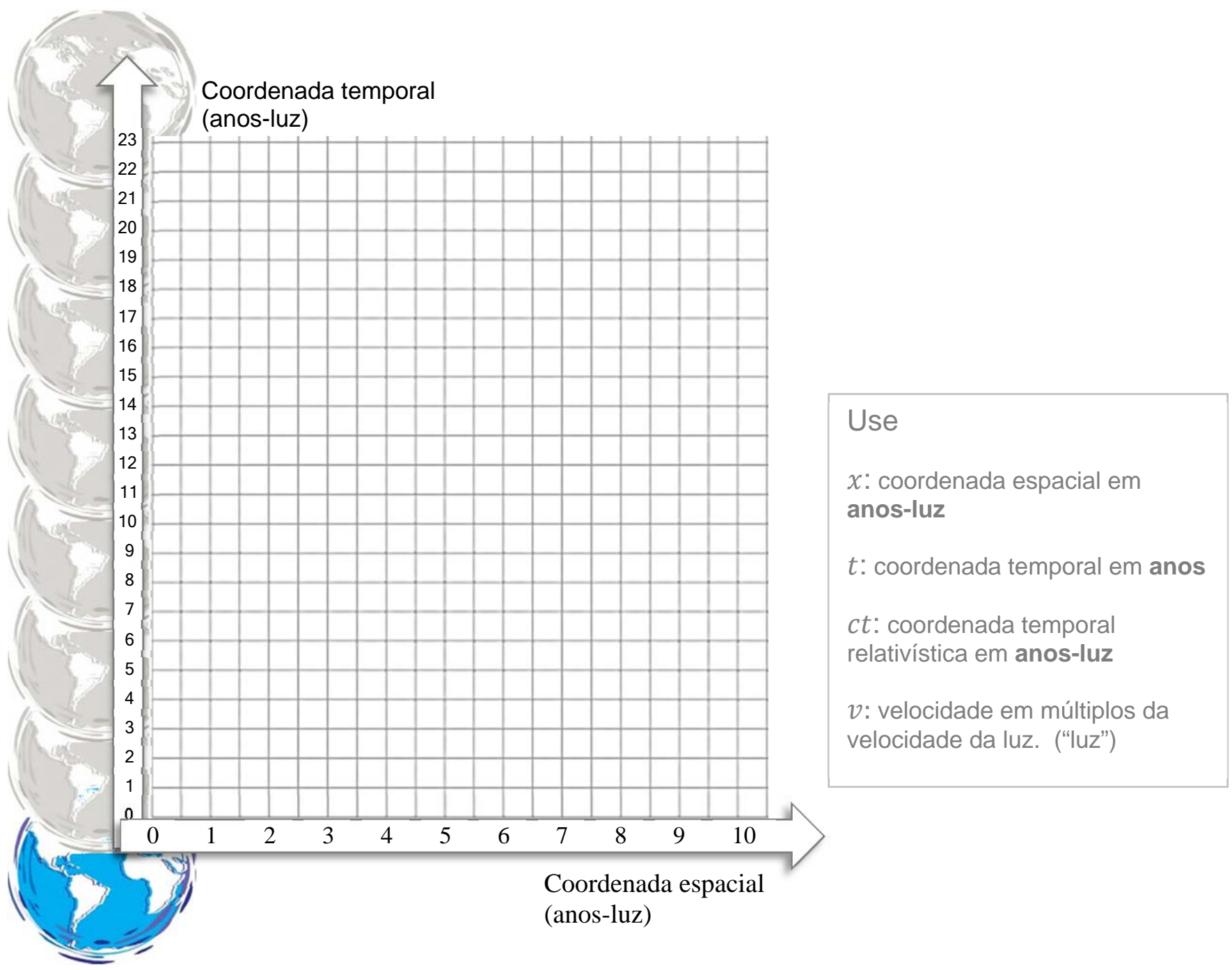

4. Determine, de acordo com os dados anteriores, os intervalos relativísticos entre os eventos partida e chegada a partir do referencial ligado à Terra utilizando o diagrama acima.

5. Determine quanto tempo demorou a viagem para Adam e para Sheldon medida em seus próprios relógios. 


\section{ATIVIDADE 9 - FOLHA DE RESPOSTAS}

1) $\Delta x=v \cdot \Delta t$

Se $\Delta t=5$ anos

$v=0,8 \mathrm{luz}$

$\Delta x=0,8$ luz. 5 anos $=4$ anos. luz
Se $\Delta t=10$ anos

$v=0,8$ luz

$\Delta x=0,8$ luz. 10 anos $=8$ anos. luz

Adam está na Terra

Sheldon está no foguete

2) Adam observa a nave ir e voltar com a mesma velocidade. Assim, o tempo de ida (10 anos) é igual ao tempo de volta. $\Delta t_{i d a+v o l t a}=10+10=20$ anos

3) Os três eventos mais importantes durante a viagem são a partida, retorno e chegada.

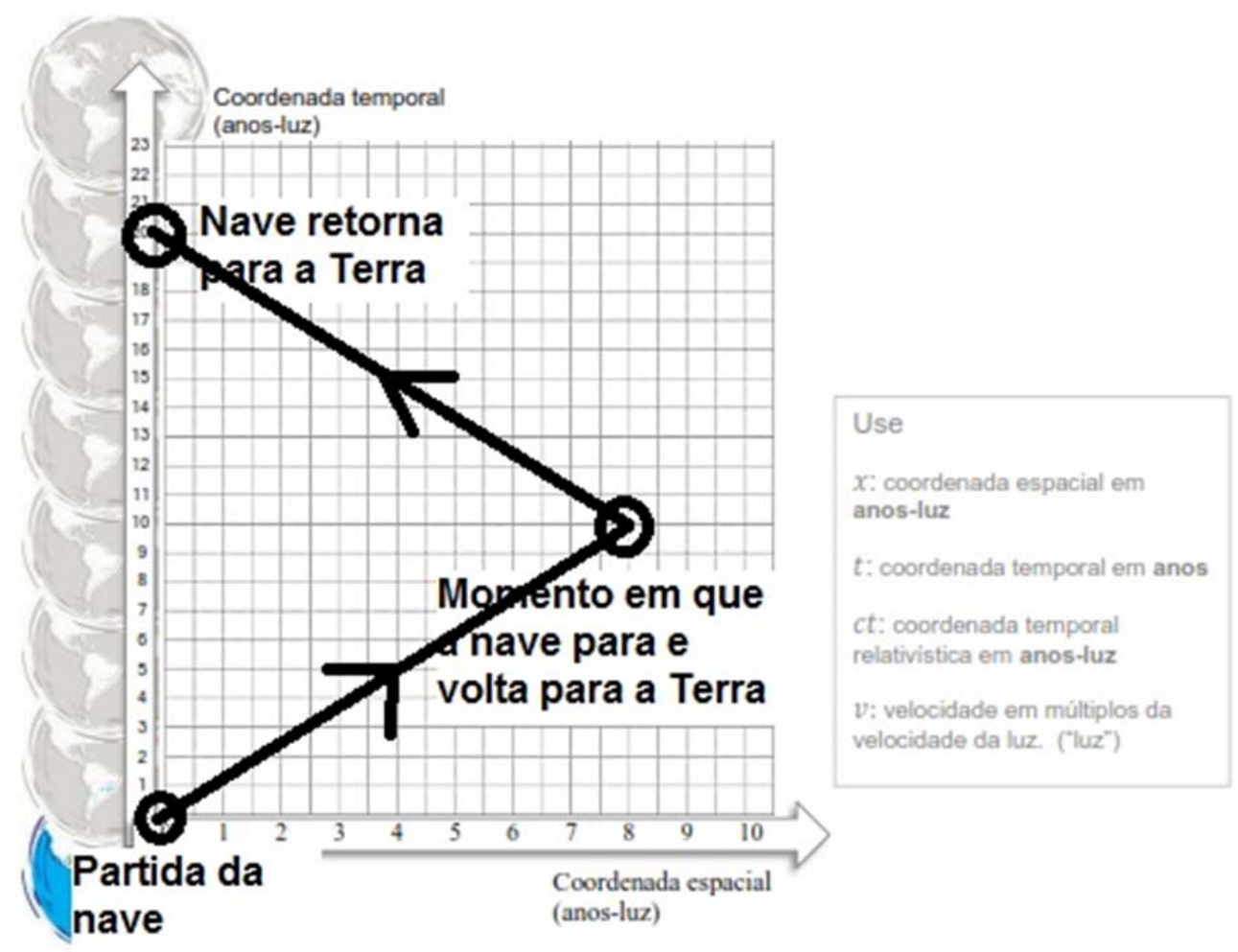


4) $\boldsymbol{I}=\sqrt{\left(c \Delta \boldsymbol{t}_{A}\right)^{2}-\left(\Delta \boldsymbol{x}_{A}\right)^{2}}=\sqrt{\left(c \Delta t_{S}\right)^{2}-\left(\Delta x_{S}\right)^{2}} \ldots$

Intervalo relativístico calculado a partir do referencial da Terra possui duas partes distintas. A primeira é a linha de mundo de ida, a segunda é a linha de mundo de volta.

$\Delta t_{i d a}=10$ anos

$\Delta x_{i d a}=8$ anos. luz

$I_{\text {ida }}=\sqrt{(1 \text { luz. } 10 \text { anos })^{2}-(8 \text { anos. luz })^{2}}$

$I_{i d a}{ }^{2}=(100-64) \cdot(\text { anos.luz })^{2}$

$\boldsymbol{I}_{\text {ida }}{ }^{2}=36 .(\text { anos. luz })^{2}$

$I_{\text {ida }}=\sqrt{36 .(8 \text { anos.luz })^{2}}$

$I_{\text {ida }}=6$ anos. luz

Neste caso o intervalo de ida e de volta são iguais pois o tempo de viagem e a distância percorrida nos dois casos são as mesma.

$I_{\text {ida }+ \text { volta }}=12$ anos.luz

5)

Para Adam a viagem demorou $\Delta t_{i d a+v o l t a}=20$ anos

Como o intervalo relativístico não depende do referencial, o tempo de viagem a partir do referencial de Sheldon pode ser calculado com o valor calculado anteriormente.

$\boldsymbol{I}_{\text {ida }+ \text { volta }}=12$ anos. luz $=\sqrt{\left(c \Delta t_{S}\right)^{2}-\left(\Delta x_{S}\right)^{2}}$

$$
\Delta t_{S}=?
$$

$\Delta x_{S}=0$,pois no referencial de Sheldon os eventos de partida, retorno e chegada ocorrem todos no mesmo lugar.

12 anos. luz $=\sqrt{\left(1 \text { luz. } \Delta t_{S}\right)^{2}-(0)^{2}}$

$(12 \text { anos. luz })^{2}=\left(1 \text { luz. } \Delta t_{S}\right)^{2}$

12 anos. luz $=1$ tuz. $\Delta t_{S}$

12 anos $=\Delta t_{S}$

Assim, o tempo entre os eventos de partida e chegada totalizam em 12 anos para Sheldon. 


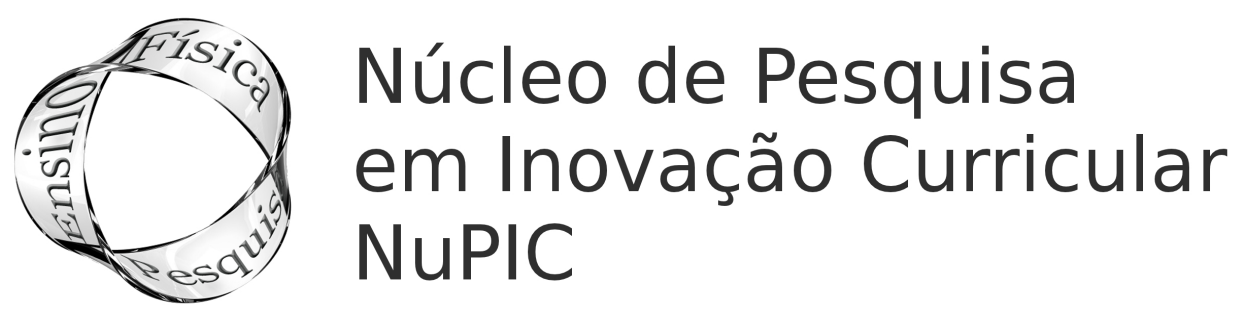

\section{PT-BR - LICENÇA DE USO DOS MATERIAIS E INFORMAÇÕES}

Todo material disponibilizado no site deverá ser utilizado respeitando-se as licenças de uso às quais se submetem. Antes de aproveitar os conteúdos, leia com atenção as formas corretas para sua utilização. O uso indevido de textos, imagens, vídeos, programas ou qualquer outro material disponibilizado, acarretará em processo criminal previsto por lei.

Os documentos, textos, imagens, audios, vídeos ou qualquer outra mídia não interativa produzidos e distribuidos, salvo indicação local, estão sujeitos às normas de uso do Creative Commons nas seguintes condições:

Este trabalho é licenciado pela Creative Commons Atribuição-Uso não-comercialCompartilhamento pela mesma licença 3.0 Unported License.

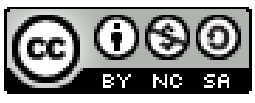

Atribuição-NãoComercial-Compartilhalgual CC BY-NC-SA

Esta licença permite que outros remixem, façam modificações e construam sobre o seu trabalho não comercialmente, contanto que atribuam crédito a você e licenciem as novas criações sob os mesmos termos.

Para fazer a citação do material, por favor inclua os logos e informações abaixo:

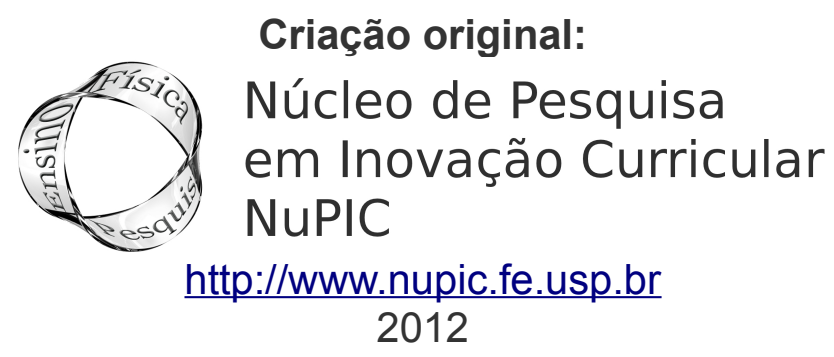

Agradecimentos:
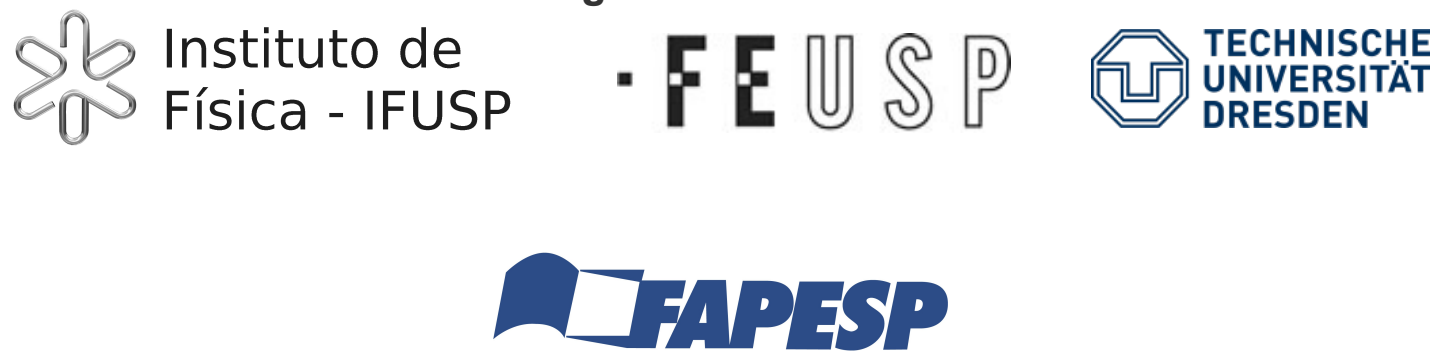


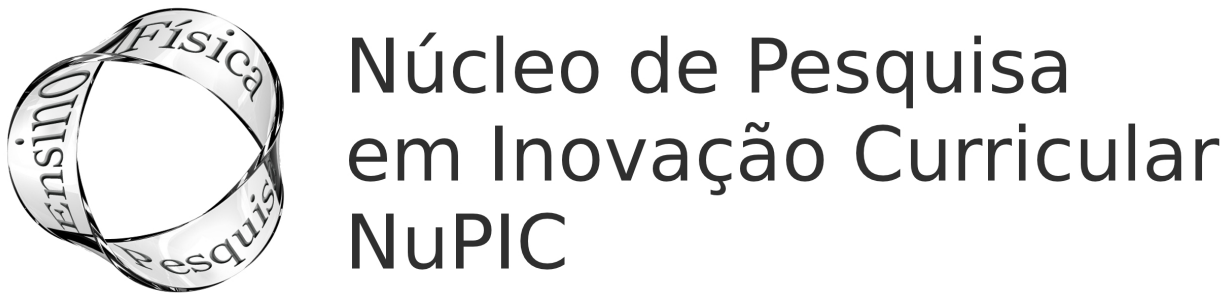

\section{EN - TERMS OF USE OF MATERIALS AND INFORMATIONS}

All material should be used respecting the use to which licenses are submitted. Before you enjoy the contents you need to read the correct forms for your use. Misuse of texts, images, videos, software or other material made available, will result in criminal prosecution as provided by law.

The documents, text, images, audios, videos or any other non-interactive media produced and distributed are subject to the use of Creative Commons the following conditions:

\section{(c) (1) (2) (2)}

Attribution-NonCommercial-ShareAlike

CC BY-NC-SA

This license lets others remix, tweak, and build upon your work non-commercially, as long as they credit you and license their new creations under the identical terms.

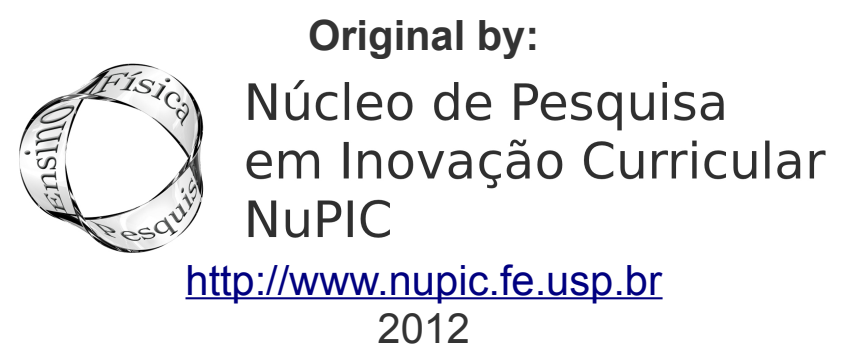

Acknowledgments:

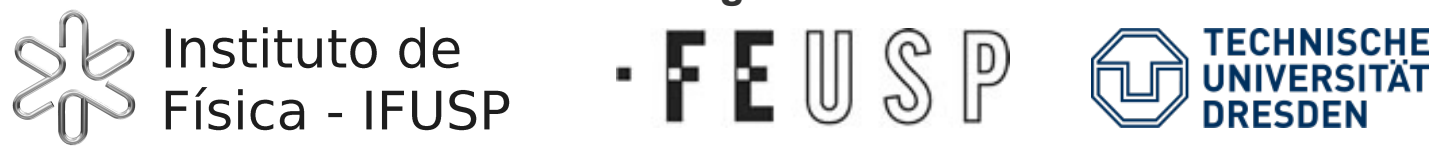


Para maior compreesão, disponibilizamos abaixo uma relação de licenças normalmente utilizadas na internet. Caso ainda permaneça qualquer dúvida, clique nos ícones ou links acima e acesse diretamente as organizações responsáveis pelo mantenimento de tais licenças.

\section{LICENÇAS RELACIONADAS À PRODUÇÃO DE PORTAIS E DOCUMENTOS}

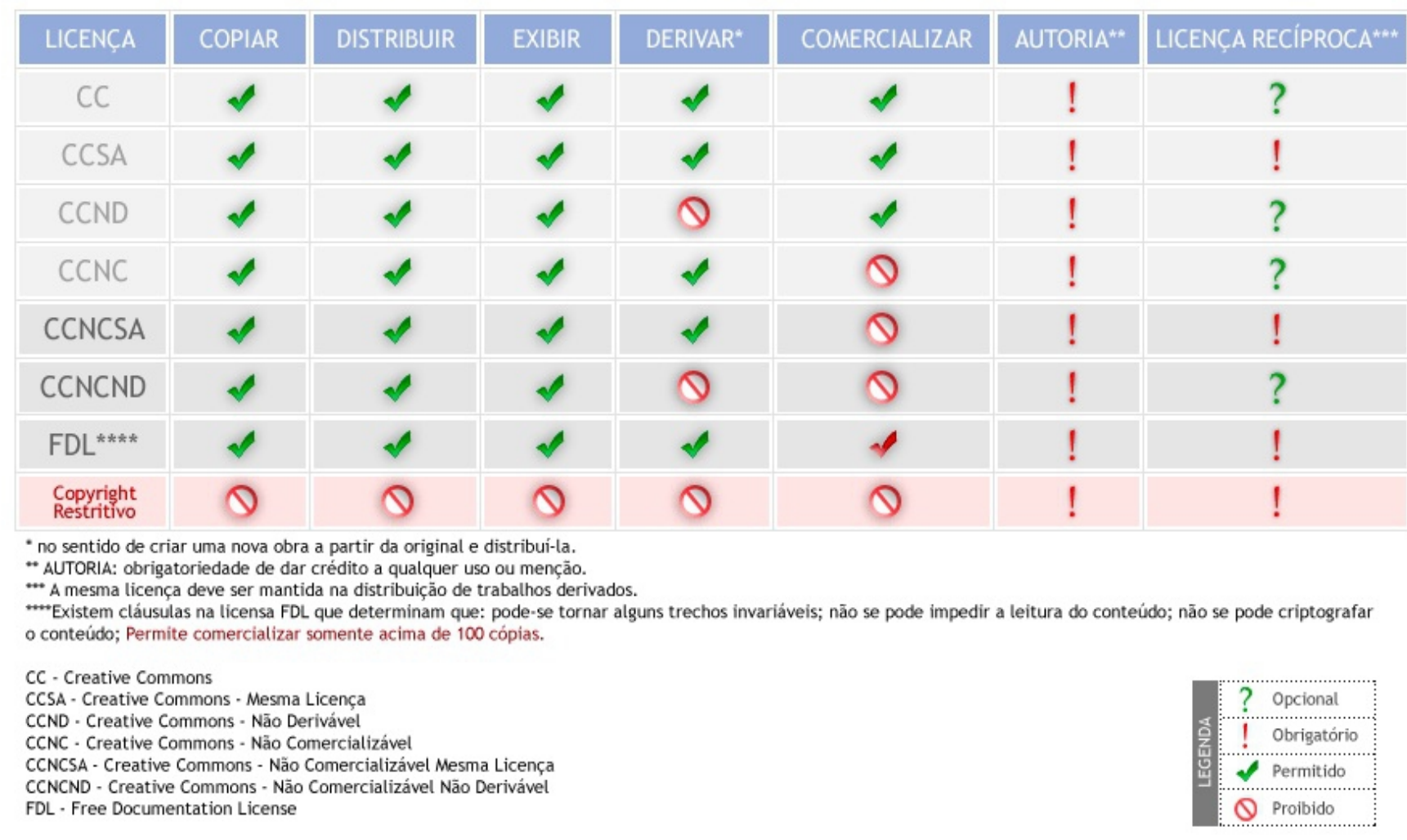

LICENÇAS ESPECÍFICAS PARA SOFTWARE

\begin{tabular}{|c|c|c|c|c|c|c|c|c|}
\hline LICENÇA & COPIAR & DISTRIBUIR & EXECUTAR & DERIVAR* & COMERCIALIZAR & AUTORIA ** & LICENÇA RECIPROCA*** & NOTAS \\
\hline GPL & 4 & 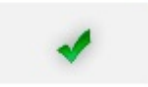 & 4 & 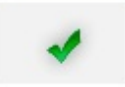 & 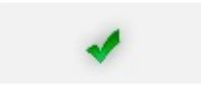 & ! & ! & $\begin{array}{l}\text { Caso software seja distribuído, o código } \\
\text { fonte deve estar disponivel sob a GPL. } \\
\text { Mais informaçōes. }\end{array}$ \\
\hline LGPL & 4 & 4 & 4 & 4 & 4 & ! & ! & $\begin{array}{l}\text { Apropriada para bibliotecas de software, que } \\
\text { poderão ser linkadas com softwares que usam } \\
\text { outras licenças. Não é necessário manter o } \\
\text { código fonte disponivel. }\end{array}$ \\
\hline BSD & 4 & 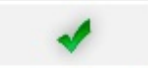 & 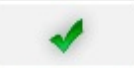 & 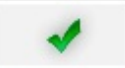 & 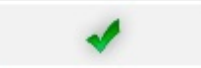 & ! & $!$ & $\begin{array}{l}\text { Não é necessário manter o código fonte } \\
\text { disponível. }\end{array}$ \\
\hline $\begin{array}{l}\text { Copyright } \\
\text { Restritivo }\end{array}$ & Q & Q & Q & Q & Q & $!$ & ! & \\
\hline & \multicolumn{2}{|c|}{$\begin{array}{l}\text { AUTORIA: obrigatoriedade de dar crédito a qualquer uso ou mençăo. } \\
\cdots \text { A mesma licença deve ser mantida na distribuiçāo de trabalhos derivados; também conhecida como Copyleft. }\end{array}$} \\
\hline \multirow{2}{*}{\multicolumn{9}{|c|}{$\begin{array}{l}\text { GPL - GNU General Public License } \\
\text { LGPL - GNU Library Public License } \\
\text { BSD - Berkeley Software License }\end{array}$}} \\
\hline & & & & & & & & \\
\hline & & & & & & & & Q Proibido \\
\hline
\end{tabular}

